\title{
LOS DEPARTAMENTOS DE CONSERVACIÓN- RESTAURACIÓN EN LOS MUSEOS ANDALUCES: ESTUDIO Y ANÁLISIS DE CASOS
}

\author{
Ma Gloria Sánchez Jurado \\ Trabajo de Investigación Tutelado
}

Tutora: Dra. Doña Ma Luisa Bellido Gant

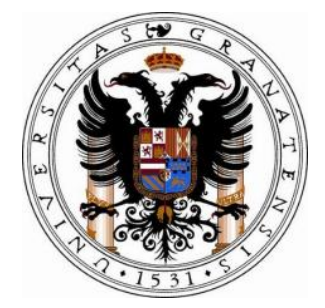

Universidad de Granada

Master-Doctorado en Historia del Arte: Conocimiento y Tutela del Patrimonio Histórico

Departamento de Historia del Arte 2009-2010 
Debemos conocer el pasado, comprender el presente y evitar la destrucción en el futuro.

Luisa Isabel Álvarez de Toledo y Maura 


\section{ÍNDICE}

1. Introducción

2. Objetivos

3. Metodología

4. El museo

4.1. Evolución del término "Museo" y su público

4.2. Funciones del museo y su manifestación en el sistema Documental de Museos (DOMUS)

4.3. Labor de investigación, documentación y difusión en el museo

5. La conservación preventiva

5.1. El origen de la conservación del Patrimonio 64-82

5.2. La conservación preventiva en el museo 83-108

5.3. La conservación de movimientos de obras, almacenes y espacios expositivos 109-130

5.4. La seguridad, conservación y áreas espaciales en los museos

6. Los Departamentos de Conservación-Restauración.

6.1. Origen y funciones de los Departamentos de Conservación-Restauración 152-191

6.1.1. Los Departamentos de Conservación-Restauración en los museos españoles

$192-210$

6. 2. El Conservador-Restaurador

6. 2.1. El Conservador-Restaurador en España 224-235

7. Panorama de los Departamentos de ConservaciónRestauración en Andalucía. Resultados obtenidos de las encuestas $236-262$

8. Conclusiones $263-267$

9. Bibliografía $267-296$ 


\section{INTRODUCCIÓN}

Este trabajo de investigación tutelado, que se encuadra dentro del Master-Doctorado de Historia del Arte: Conocimiento y Tutela del Patrimonio, ha pretendido realizar un estado de la cuestión, análisis y propuesta de intervención sobre los distintos aspectos que inciden en la Conservación-Restauración de los Bienes Culturales mejorando el Área o Departamento de Conservación-Restauración de los museos de Andalucía.

El trabajo se estructura en once capítulos que ofrecen una aproximación general a las diferentes características que envuelven a la Conservación-Restauración del Patrimonio y de los museos.

De esta manera, en el primer capítulo se analiza brevemente el surgimiento de los primeros museos, su evolución y el papel que ha tenido la sociedad en este tipo de instituciones. A lo largo de los siglos, y según ha ido evolucionando el concepto de esta institución, también ha evolucionado su público. Por lo que acercar los museos a la comunidad ha sido una tarea reciente, siendo los estudios de público una herramienta fundamental y útil para entender la relación entre éstos y sus usuarios.

En el capítulo segundo se aborda de forma general las funciones principales de la institución museística: la investigación, conservación-restauración, documentación y difusión, haciendo especial hincapié en el Sistema Documental de Museos (DOMUS). Así, los museos son instituciones 
encargadas de la difusión, la enseñanza -ya que informan y comunican al público los fondos de la institución-, la investigación -ya sea de las colecciones o del propio museo-, la documentación de datos e información, así como de la conservación-restauración de las piezas que lo integran, y por último, de su administración y gestión. La herramienta que se usa actualmente para llevar a cabo algunas de estas funciones es el programa informático DOMUS. Se trata de un instrumento de trabajo útil, eficaz y práctico que permite un intercambio de información entre las instituciones museísticas.

El tercer capítulo se centra más detenidamente en la labor de investigación, documentación y difusión en el museo. En un principio las instituciones tenían como objetivos principales el acopio y la conservación de los bienes que poseían. Poco a poco se han ido incorporando otras actividades y funciones, como son la investigación, la documentación y en último lugar, la difusión. De tal modo que podemos decir que el fin último común de las dos primeras -la investigación y la documentación- es la difusión del conocimiento.

Se presta especial interés en el origen de la Conservación y Restauración del Patrimonio en el capítulo cuarto. Acciones que han estado ligadas a los cambios de la sociedad y se han visto influidas y condicionadas por la ideología y las necesidades sociales y culturales del momento.

Posteriormente, en el capítulo quinto, nos adentramos en la evolución y desarrollo que ha tenido la conservación y la restauración en el ámbito museístico. Al ser dos conceptos 
tan relacionados, a lo largo del tiempo han sido confundidos y se han llegado a identificar el uno con el otro, por ello se explica cada tarea por separado -su definición, características, historia y su actividad dentro del museoaunque en ambos casos estemos hablando de conservación.

Los capítulos sexto y séptimo se centran en la conservación de movimientos de obras, almacenes, espacios expositivos y la seguridad e higiene necesaria en el trabajo y para el trabajador. Ya que no sólo está en juego los bienes que se depositan en el museo, sino que es igualmente importante vigilar el propio edificio -y el espacio circundante-, así como velar por la seguridad de sus trabajadores y, por supuesto, de sus visitantes.

Se continua comentando, en el octavo y noveno capítulos, las diferentes características de los Departamentos de Conservación-Restauración, haciendo una breve referencia acerca de su origen, las circunstancias en que se crean, su evolución a lo largo del tiempo, sus funciones principales, así como el personal profesional que forma este tipo de Departamentos. Nos hemos detenido a analizar brevemente los rasgos principales que definen los Departamentos de Conservación-Restauración españoles. Áreas que van adquiriendo cada vez más importancia dentro de las instituciones museísticas.

En el décimo y undécimo capítulos se hace un breve recorrido por la historia y evolución del conservadorrestaurador de museos, las funciones principales que desempeña dentro de la institución, así como la formación que ha tenido a lo largo de los años y su código ético. Perfil que no existía como tal tiempo atrás, sino que se 
consideraban dos profesiones diferentes -la conservación y la restauración-, que con el tiempo llegaron a unirse. Concluimos este capítulo haciendo referencia a la evolución que este perfil profesional ha experimentado en España.

Por último, a través de la investigación de campo, eminentemente práctica, se analizan las diferentes instituciones museísticas andaluzas seleccionadas. Se trata analizar la situación real de estos departamentos, buscar estrategias para resolver la problemática existente en las Áreas o Departamentos de Conservación-Restauración de los museos y mejorar su situación actual.

El trabajo concluye con un capítulo dedicado a las conclusiones obtenidas de este trabajo teórico-práctico y un apartado bibliográfico que complementa el objeto de estudio.

Se acompaña el trabajo con un CD-ROM con los anexos donde se incorpora el cuestionario y la carta de presentación enviados a los diferentes museos, la lista con la información relevante sobre las diferentes instituciones museísticas de Andalucía -en las ciudades de más de 60.000 habitantes-, los cuestionarios cumplimentados y las respuestas de los centros seleccionados. 


\section{OBJETIVOS}

Concienciar y sensibilizar a la sociedad sobre la importancia de nuestro legado artístico y cultural, así como de nuestra responsabilidad de protegerlo y conservarlo, es un componente fundamental para la transmisión del Patrimonio Cultural a las generaciones futuras. Bienes que por su carácter único e irrepetible forman el testimonio de un pasado pero también de un presente y un futuro y que por tanto, es esencial conocer los aspectos y evolución de su conservación y restauración.

Del mismo modo, la institución museística cobra un gran valor en la actualidad, ya que ha actuado a favor de prolongar esta existencia cultural, su gestión y su difusión, por lo que es importante reflexionar sobre su historia y desarrollo a lo largo del tiempo.

Uno de los objetivos fundamentales de esta investigación es conocer el estado y la situación en la que se encuentran los Departamentos o Áreas de ConservaciónRestauración de los museos de Andalucía. Valorar sus carencias, competencias, infraestructura, grados de capacitación, gestión interna, organización del trabajo...

En segundo lugar analizar las diferencias significativas entre los museos estudiados -según los departamentos- mediante el análisis comparativo y evaluación de los resultados adquiridos. 
Este análisis nos permitirá abordar el tercer objetivo, esto es definir el perfil profesional de los integrantes de los Departamentos de Conservación-Restauración dentro de los museos.

Por último definir los instrumentos y estrategias de actuación que permitan a los Departamentos de ConservaciónRestauración realizar y coordinar actividades además de aprovechar sus propios recursos y así mejorar su estructura interna a través de nuevas oportunidades. 


\section{METODOLOGÍA}

El trabajo de investigación se estructura en dos bloques bien diferenciados, una parte teórica, imprescindible para la contextualización histórica del objeto de estudio y una práctica que aborda directamente la poblemática estudiada.

Para el cumplimiento de los objetivos, en primer lugar se realizó un análisis bibliográfico y una búsqueda de información para desarrollar ambas partes. Se consultaron fuentes impresas en varias bibliotecas especializadas (Universidad de Granada, Universidad de Sevilla, Instituto Andaluz del Patrimonio...) y fuentes electrónicas disponibles en la red.

La parte teórica, está constituida por once capítulos que tratan sobre el origen y evolución del museo y la conservación del Patrimonio. Se hace un recorrido por la génesis y desarrollo del museo a lo largo de los siglos, su público, funciones -investigación, documentación, conservación, difusión-, concluyendo con los Departamentos de Conservación-Restauración y el perfil profesional del conservador-restaurador.

La investigación práctica se aplicó a los museos de Andalucía en función del número de habitantes de sus ciudades ${ }^{1}$. Para ello se realizó un cuestionario constituido por veintiuna preguntas -en algunas de ellas formadas por

\footnotetext{
${ }^{1}$ Exactamente con un número superior de 60.000 habitantes.
} 
otras aclaratorias- centrándose en el Departamento de Conservación-Restauración del museo. La longitud del cuestionario está calculada para que no sea cumplimentado en un tiempo superior a unos quince minutos.

El cuestionario está formado por las siguientes preguntas:

1. Dispone el museo de Departamento o Área de Conservación?, ¿Cómo lo denominan?

2. ¿El Departamento de Conservación es visitable?

3. ¿Dispone el museo de laboratorio o taller de restauración?

4. ¿Dispone el museo de personal técnico encargado de la conservación-restauración de las obras?

5. ¿La plantilla es suficiente? ¿Cuántos miembros la integran?

6. ¿Qué formación poseen?

7. ¿Pertenece el personal a alguna Asociación?

8. ¿El Departamento de Conservación ofrece servicios profesionales a coleccionistas, artistas e instituciones culturales que requieran de evaluación, análisis y conservación de obras? ¿Cuál es su tarifa?

9. ¿Qué instrumentos de investigación y mantenimiento de la colección posee el museo?

10. ¿Qué líneas generales de investigación lleva a cabo el Departamento de Conservación del museo?

11. ¿Realiza programas o actividades orientadas a fomentar el principio de custodia compartida de la colección del museo?

12. ¿Colabora con otras instituciones del ámbito de la preservación de los bienes culturales? 
13. ¿Dispone el departamento/área de la seguridad e higiene en el trabajo? ¿de qué lo compone?

14. ¿De qué nuevos medios tecnológicos dispone el departamento/área/taller/laboratorio de conservaciónrestauración del museo?

15. ¿Qué objetivos, programas y recursos ofrece el departamento de conservación-restauración?

16. ¿Por qué ley se rige el Departamento de conservaciónrestauración?

17. ¿Dispone de un Plan de Protección de Colecciones ante Emergencias?

18. ¿Dispone el museo o departamento de un boletín u otro tipo de publicaciones periódicas?

19. ¿Dispone de documentación de conservación? ¿Se puede consultar por los usuarios o es de uso interno?

20. ¿Qué requisitos son necesarios para acceder al puesto de conservador y restaurador?

21. ¿El departamento ofrece becas de formación de conservación-restauración de obras?

Además, se realizaron entrevistas personales a directores de museo y se hicieron llamadas telefónicas y visitas a las propias instituciones.

Una vez elaborados los cuestionarios, se enviaron vía email -junto a una carta de presentación- a los museos de titularidad pública y de titularidad privada.

El trabajo práctico se realizó entre el periodo de marzo a octubre de 2010. Estos ocho meses requirieron de un control y seguimiento exhaustivo hacia las instituciones implicadas en el proyecto para intentar que el mayor número 
de ellas respondiera al cuestionario elaborado y remitido vía internet.

Posteriormente se recogió manualmente la información y resultados obtenidos de las encuestas y se analizaron con el programa gráfico DAFO (Debilidades, Amenazas, Fortalezas y Oportunidades) ${ }^{2}$. De esta manera se podrán recoger las posibles estrategias a adoptar y así implantar nuevas acciones, medidas y proyectos que mejoren la situación de los Departamentos de Conservación-Restauración de los museos de Andalucía.

\footnotetext{
2 Consiste en mostrar, en un gráfico o una tabla resumen, la evaluación de los puntos fuertes y débiles de una empresa. Las fortalezas y debilidades corresponden al ámbito interno de la institución, realizándose el análisis de las fortalezas con las que cuenta y cuáles las debilidades que impiden el cumplimiento de sus objetivos. Mientras que las amenazas y oportunidades corresponden a factores externos que influyen negativamente a la institución.
} 


\section{EL MUSEO}

En este apartado se hablará del origen y evolución del término "museo" a lo largo de los años y sus funciones principales: la investigación, conservación, documentación y difusión, haciendo especial hincapié en el Sistema Documental de Museos (DOMUS) y el papel que ha tenido la sociedad -el público- en este tipo de instituciones.

\subsection{EVOLUCIÓN DEL TÉRMINO "MUSEO" Y SU PÚBLICO}

Cuando una experiencia espacial significativa es compartida por un número de personas, esta es la génesis de un espacio público.

Fumihiko Maki

A lo largo de los siglos, y según ha ido evolucionando el concepto de museo, también ha evolucionado su público.

Hoy en día un museo es un espacio que alberga la cultura y la tradición de una sociedad con el fin de transmitir y comunicar nuestro pasado y proteger su memoria a las futuras generaciones. Puede ser un lugar donde no solamente se conserven y mantengan en buen estado las piezas

3 Arquitecto japonés que ha recibido varios premios, entre ellos el Premio Pritzker de Arquitectura en 1993. 
que contiene, sino además un punto de encuentro entre personas de diferentes culturas, edad, clase social... ${ }^{4}$

En el ámbito de los museos se han producido mejoras tanto en su funcionamiento interno como en su evolución. Acercar los museos a la comunidad ha sido una tarea reciente.

La caída del Antiguo Régimen a finales del siglo XVIII originó la aparición de los museos públicos a raíz -entre otras razones- de la incautación de obras de la Iglesia y la nobleza. Las cámaras de maravillas, gabinetes de curiosidades y otras colecciones privadas de aristócratas y monarcas, que a mediados del siglo XVIII comienzan a formar parte del Patrimonio Nacional, se encuentran entre los antecedentes del museo. Por esta razón, el museo nace centrado en las piezas y objetos que alberga con funciones exclusivas de colección y conservación de las mismas. El público de estos museos era reducido y especializado, accediendo al mismo con previa autorización. Pero no es, sin embargo, hasta 1793 -fecha de inauguración del Louvre, 10 de agosto- cuando se considera que han nacido los grandes museos europeos ${ }^{5}$. Por tanto, éstos se convirtieron en los depositarios de unos valores artísticos.

A partir de los cambios que se suceden en el siglo XVIII, -como el paso de las colecciones reales a museos públicos, la consolidación del mercado del arte y la creación de museos por las Academias científicas, entre otros-, es

\footnotetext{
4 MARCO SUCH, María. Estudio y análisis de los museos y colecciones museográficas de la provincia de Alicante. Alicante. Universidad, 1998. (tesis doctoral)

5 PÉREZ SANTOS, Eloisa. Estudio de visitantes en Museos. Metodología y aplicaciones. Gijón. Trea, 2000.
} 
cuando se modifica el acceso del público a las colecciones de arte $^{6}$. Comienzan a abrir sus puertas a un visitante menos especializado por lo que al mismo tiempo se potencia el componente didáctico de la institución.

Será G. H. Rivière, el primer presidente del Comité Internacional de la Organización de Museos - a partir de ahora ICOM-, quien defina un concepto general de Museo en 1951:

\section{La palabra museo designa toda institución} permanente, administrada en el interés general con vistas a conservar, estudiar, valorar... y exponer para la delectación y educación del público un conjunto de elementos de valor cultural...

Las instituciones museísticas siempre han tenido una intención y propósito, pero éstos han ido cambiando con el paso del tiempo. A principios del siglo XX, antes del nacimiento de la Nueva Museología (1971), el fin que perseguían la mayoría de los museos era científico, lo que quiere decir que cuando se realizaban labores de investigación, documentación, conservación-restauración, acopio o difusión de las colecciones, lo hacían buscando mejorar el conocimiento científico de éstas.

A partir de esta fecha, 1971, emergen otros objetivos; entre ellos hacer un museo más institucional o comunicativo.

En el año 1974 el ICOM definía así el Museo:

\footnotetext{
6 AlAminos LÓPEZ, Eduardo. "El acceso a los museos: evolución histórica". En ANABAD, Tomo 40, $\mathrm{N}^{\circ}$ 2-3, 1990, pp. 173-178.

7 Estatutos del ICOM de 1951.
} 


\section{(...) institución al servicio de la sociedad,} que adquiere, conserva, comunica y presenta con fines amplios del saber, de salvaguardia $y$ de desarrollo de patrimonio, de educación y de cultura, los bienes representativos del hombre y la naturaleza ${ }^{8}$.

A lo largo del tiempo y de la historia se han producido grandes e importantes cambios culturales en la sociedad, o por lo menos en parte de ésta. Esto se debe a que se ha ido construyendo un futuro a través de la transmisión de conocimientos (leyes, valores, costumbres,...) para contribuir y ayudar al desarrollo del ser humano y al progreso de la sociedad para así adaptarse mejor al medio ambiente que nos rodea.

Entre los múltiples cambios culturales que se han producido en todo el mundo a lo largo de la historia, destaca -sin lugar a dudas- lo referente a los museos, que además de crecer y aumentar considerablemente su número, se han ido renovando e innovando. De este modo, abren sus puertas a la sociedad, al ciudadano, por lo que necesitan transformar sus programas (museológico, museográfico, expositivo, arquitectónico, educativo...) teniendo en cuenta la cantidad de público visitante.

Los museos pensaban de sí mismos que eran lugares para la élite, no obstante, abrieron sus colecciones permanentes y exposiciones a un público cada vez más amplio y vieron éstas como un posible diálogo abierto entre el personal del museo y el visitante al mismo. Así, tomó conciencia de sí mismo, se

8 Estatutos del ICOM de 1974. Titulo 2, artículo 3. 
hizo más transparente, más responsable y mucho más democrático ${ }^{9}$.

Hoy en día, tal como entendemos el museo, aparece con un significado totalmente didáctico e instructivo, pero esto no siempre ha sido igual. En un principio, los museos se entendían como centros de investigación, siendo su acceso realmente complicado, ya que se restringía la entrada solamente para personal cualificado.

En la actualidad, el museo se considera como un medio de comunicación que tiene que llegar a un público cada vez más amplio y abundante. El museo posee una función educativa y el público es su usuario, por lo que sus acciones deben estar encaminadas a analizar y captar a estos visitantes.

En el mundo anglosajón, a partir de 1870, las clases menos adineradas y los grupos de escolares comenzaron a tener mayor importancia en el mundo museístico. El fin era enseñar y formar a la sociedad, tanto a adultos como a niños, proponiendo nuevas actividades como las visitas a los museos a grupos escolares o ampliando el horario de visita ${ }^{10}$.

Tras la primera Guerra Mundial, se produce un cambio y un retroceso en este aspecto, el personal del museo, los conservadores, se oponen a transformar el museo en un centro de divulgación, causando con esto daños en su capacidad para la investigación. No obstante, tras la segunda Guerra

\footnotetext{
9 CABAllero GARCíA, Luis. "El público en el museo: sistemas de evaluación". Curso de Iniciación a la Museología. Centro de enseñanza virtual Liceus. Madrid. Universidad de Alcalá, 2007. 10 Ibídem.
} 
Mundial, nuevamente se permite la entrada a la institución al público en general, sobre todo en los países de occidente ${ }^{11}$.

Hay que decir que los museos de Norteamérica no se vieron afectados por esta guerra, pero en Europa la situación era completamente diferente. Casi todos los museos -tanto en el edificio como en las colecciones- sufrieron graves daños; destrozos, ruinas, saqueos e incluso desapariciones. Lo lamentable es que esta situación se prolongó por muchos años.

Según Karsten Schubert, los museos europeos después de la segunda Guerra Mundial fueron abandonados y muchos -tanto entre los políticos como entre el público- los consideraban anticuados bastiones de cuestionables valores y aspiraciones burgueses. Y tenían, sin excepción, un aspecto abatido, deslucido y aburrido, siendo los museos alemanes los peor parados $^{12}$.

Esto se debió a varios fenómenos internacionales: la incorporación del derecho de la sociedad a las instituciones museísticas y la influencia de éstas cada vez más en los hábitos sociales y las costumbres, la incidencia del nacionalismo que provocó cambios en los museos -tanto cultural como políticamente-, el interés que empezó a mostrar la sociedad europea por otras culturas -lo exótico-, y la creación de ambiciosos complejos museológicos ${ }^{13}$. Sin olvidarnos de la reconstrucción y recuperación económica de la posguerra, las infraestructuras, la vivienda, la educación

\footnotetext{
11 Ibídem.

12 Ibídem.

13 ALAMinos LÓpez, Eduardo. Idem. pp. 173-178.
} 
y las artes escénicas, el turismo de masas y la cultura de ocio y los cambios culturales de los años sesenta ${ }^{14}$.

En los años ochenta, como consecuencia de estos cambios culturales y políticos, se redescubrió la existencia del público en los museos. Éstos, llámese espectadores o visitantes de museos, son aquellas personas o sujetos que aprecian las obras de arte y artefactos que observan a su alrededor. Por ello, juegan un papel muy importante -por no decir esencial- a la hora de cumplir los objetivos que un museo se plantea.

De igual modo, descubrieron que no sólo existía un tipo de visitante sino que había gran variedad de ellos. Encontrar la mejor manera de ocuparse de este personal ha pasado a ser en el gran reto para la institución museística.

La percepción del museo por parte del público cambió de lo educacional a lo recreativo, de la investigación y la exposición a la preocupación por el público y su servicio ${ }^{15}$.

Como afirma Luis Caballero, conservador del Museo de El Greco (Toledo), se podría decir que en general, hasta comienzos de siglo XX, los museos han sido visitados únicamente por personas expertas y algún que otro visitante motivado ${ }^{16}$. Estando lejos del acceso a todos los públicos a la institución, ya que además, sólo se centraba en sus colecciones y exhibirlas correctamente.

14 SCHUBERT, Karsten. El museo. Historia de una idea. De la revolución francesa a hoy. Granada. Turpiana, 2008.

15 SCHUBERT, Karsten. Idem.

16 CABALLERO GARCíA, Luis. Idem. 
Afortunadamente, en nuestros días, el museo va dejando de ser un recinto distinguido y selecto, dedicado casi únicamente a una sociedad erudita y sabia, y actualmente es visitado por todo tipo de usuarios, los cimientos que dan significado y razón de ser a los museos. Por tanto, este concepto ha evolucionado y se concibe el museo como una institución que está al servicio de la sociedad, por lo que supone un razonable interés por sus visitantes y sus necesidades, tanto físicas, sociales, culturales o simplemente por puro deleite estético ${ }^{17}$.

El Real Decreto $620 / 87$ de 10 de abril por el que se aprueba el Reglamento de Museos de titularidad estatal y el Sistema español de Museos, establece la difusión como una de las tres áreas básicas de la estructura interna de los museos. La difusión tendrá como finalidad el acercamiento del museo a la sociedad mediante métodos didácticos de exposición, la aplicación de técnicas de comunicación y la organización de actividades complementarias tendentes a estos fines ${ }^{18}$.

Karsten Schubert afirma que los museos se han abierto en diferentes direcciones; hacia nuevos sectores del público que hasta hacía poco sentían que el museo no era su sitio; hacia el arte y los artistas que no habían sido representados o se habían considerado más allá del ámbito institucional; y

\footnotetext{
17 ARIAS SERRANO, Laura. "El papel del público en el museo de hoy". En ANABAD, Tomo 40, $\mathrm{N}^{\circ}$ 2-3, 1990, pp. 178-188.

18 El Real Decreto $620 / 87$ de 10 de abril (B.O.E. de 13 de mayo) por el que se aprueba el Reglamento de Museos de titularidad estatal y el Sistema español de Museos.
} 
hacia nuevas voces en el campo de la conservación, para las que no había sitio en la narrativa lineal del pasado ${ }^{19}$.

Así, en este nuevo contexto, el museo se encamina hacia dos grandes desafíos; por un lado a captar a nuevos visitantes, y por otro, a negociar y resolver esa experiencia museística de una forma óptima. De esta manera, el usuario se convierte en un asiduo al museo y no en un mero visitante que acude al museo de vez en cuando. Esto dependerá, como no, del grado de satisfacción final y el interés que haya provocado en el público la visita al museo.

Cualquier institución museística tiene que dedicar gran parte de su tiempo y trabajo en conocer y saber lo que su público opina tras la visita. Para eso, es un requisito imprescindible evaluar -en la medida de lo posible-, el resultado y las conclusiones de las actividades que se realizan en el mismo. Es decir, se ven en la obligación de organizar día a día su programación según lo que piden o necesitan estos visitantes.

Lo primero que se debe plantear una institución es quién es su público visitante, cuáles son sus características principales, en qué se diferencian éstas respecto de las personas que no visitan los museos, qué imagen tienen ambas los que asisten como los que no- de estas instituciones, cuál es su perfil social y cultural, y por último, cuál es el grado de satisfacción obtenido después de la experiencia museística ${ }^{20}$.

19 SCHUBERT, Karsten. Idem.

20 GARCíA BLANCO, Ángela. "¿Usuarios o visitantes de museos?". En Museo, $\mathrm{N}^{\circ}$ 6, 2002, pp. 1-18. p. 174. 
Pero hay que diferenciar dos tipos de visitantes del

museo; el usuario real, el que visita el museo con frecuencia, y el potencial ${ }^{21}$. Por tanto, se tiene que estudiar quienes son los que realmente visitan las instituciones museísticas. Esta información se obtiene a través de encuestas, cuestionarios y entrevistas realizadas a grupos que se seleccionan previamente, para así observar y analizar su comportamiento además de conocer sus opiniones respecto a los diferentes aspectos del museo.

Si hay que decir que es realmente complejo que una institución atraiga a todo el mundo, pero para que eso llegue a ser una realidad debe centrarse en identificar su usuario más frecuente y tratar de crear estrategias para mantenerlo.

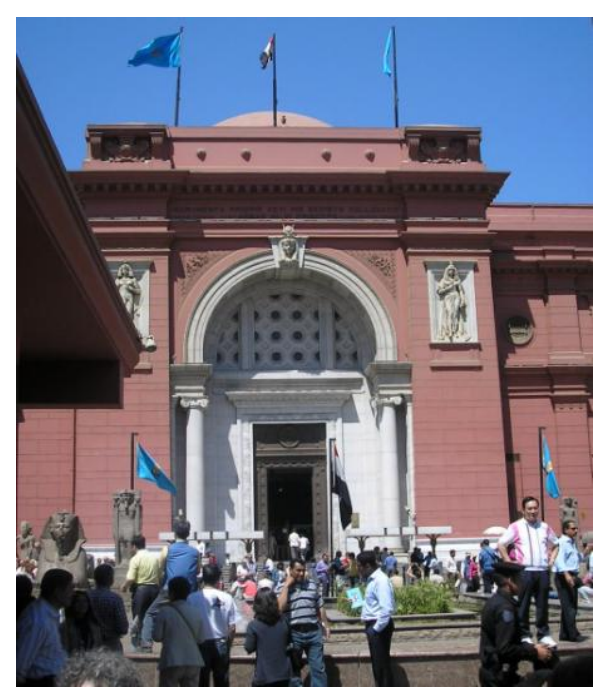

Figura 1. Visitantes del Museo de El Cairo (Egipto).

Foto de la autora

Una gran cantidad de visitantes todavía sigue considerando que el museo es un recinto aburrido y que hay

21 CABALLERO GARCíA, Luis. Idem. 
que estar en silencio -o tratar de estarlo- para no molestar a los demás visitantes, pero también cada vez son más los que lo consideran como un lugar entretenido, atractivo e interesante gracias a los medios de comunicación, las nuevas tecnologías y los programas educativos.

Desde el primer momento, el visitante se encuentra con ciertas dificultades -el acceso al museo, encontrar el recorrido de la exhibición y orientarse, localizar lo que está buscando, disfrutar la exposición que está contemplandoque tiene que solucionar y es el propio museo el que tiene que ayudarle a superar estas cuestiones ${ }^{22}$. Todo este camino resulta más sencillo si encontramos en él puntos de información, señalizaciones, textos informativos... Y si además todo esto resulta atractivo, comprensible, conciso y fácil de entender, mejor que mejor. Toda esta información es de gran importancia para el visitante a la hora de ubicarse en el recinto y escoger las actividades y servicios que más le interesa. Lo que busca principalmente es que le sorprendan, que disfrute y se divierta mientras aprende.

Y, ¿qué son los estudios de visitantes?

La American Association of Museums ${ }^{23}$ (AAM), a través del Committee on Advance Research and Evaluation ${ }^{24}$ (CARE), define los estudios de visitantes (visitors studies) como:

El proceso de obtención de conocimiento sistemático de y sobre los visitantes de museos, actuales $y$ potenciales, con el propósito de incrementar y utilizar dicho conocimiento en la

\footnotetext{
22 Ibídem.

23 Asociación Americana de Museos.

24 Comisión de Investigación Avanzada y Evaluación.
} 
planificación y puesta en marcha de aquellas

actividades relacionadas con el público ${ }^{25}$.

Los estudios de visitantes son una herramienta realmente fundamental y significativa, además de útiles, para entender la relación entre el museo y sus usuarios ${ }^{26}$. El visitante es un interlocutor activo y por tanto sus opiniones, críticas o sugerencias, -tanto positivas como negativas-, son esenciales para llevar a cabo cualquier propuesta museística.

Estos estudios se han ido realizando desde hace varias décadas y poseen una larga tradición entre los países desarrollados ${ }^{27}$, pero hoy en día es una preocupación que existe cada vez más en los museos y que se ha ido incorporando a las típicas funciones de los mismos, como son la conservación, la investigación y la difusión.

Su propósito fundamental es conocer quienes son sus visitantes -y también los "no visitantes"- y comprender mejor sus gustos, curiosidades, preocupaciones, necesidades 0 intereses.

25 Citado por Eloisa Pérez en Estudio de Visitantes de Museos. Gijón. Trea, 2000. pág. 62. Professional standard for the practice of visitor research and evaluation in museums, Comité on Audience Research and Evaluation (CARE), Washington, D.C., American Association of Museums, 1991.

26 GonzÁLez, María Irene, CASTRO, Mario. Estudios de Público en los Museos de

Dibam. ww. dibam.cl/descarga rec.asp?id recurso=62 (consultado el 17 de junio de 2010).

27 Ibídem. 
Es necesario tener información sobre cómo y porqué al visitante le interesan -o no le interesan- las actividades, servicios y tareas que los museos le ofertan. A partir de aquí y dependiendo de estos datos, el museo podrá actuar según sus prioridades y tendrá que ser capaz de adecuar y cambiar sus características a estas nuevas exigencias y necesidades que plantean sus usuarios.

Así, los estudios de público nos proporcionan información sobre los diferentes tipos de visitantes por sus características socio-demográficas y comprender, además, otros aspectos como sus motivaciones, expectativas, los conocimientos previos a la visita -antes de enfrentarse al mensaje expositivo-, la duración de la misma, su valoración... ${ }^{28}$ Es decir, nos permitirá conocer las necesidades básicas y puntuales de cada uno de los diferentes tipos de espectadores del museo y medir, por tanto, su nivel de satisfacción final.

Según Eloisa Pérez las primeras investigaciones de cierto rigor sobre visitantes de museos aparecen a finales de los años veinte en Estados Unidos, impulsadas por la Asociación Americana de Museos (AAM), que encarga a Edward S. Robinson, profesor de Psicología de Yale (Connecticut, Estados Unidos), un estudio sobre el comportamiento de los visitantes entre 1925 y 1927. Robinson publica en 1928 el primer estudio de observación sistemática del comportamiento del visitante de museos ${ }^{29}$.

28 DE LOS ÁNGELES, Margarita, CANELA, María, GARCíA BLANCO, Ángela, POLO, Má Ángeles. "Los estudios de público, un instrumento de trabajo. La gestación de un proyecto". En Mus-A, No 10, 2008, pp. $31-35$.

29 PÉREZ SANTOS, Eloisa. Idem. p. 22. 
En los comienzos de los estudios de público del siglo XX -aproximadamente desde los años veinte hasta los años cincuenta-, éstos se encaminaron a valorar los efectos de las exposiciones sobre el visitante del museo. Pero es en los años sesenta cuando aparecen los primeros investigadores de visitantes de museos, aunque en años anteriores ya existían labores relativamente importantes sobre el público ${ }^{30}$.

Es a partir de los años ochenta cuando estos estudios están relacionados con los cambios y transformaciones que han sufrido los museos como instituciones. Ejemplos claros de estos estudios y análisis de público lo encontramos en Merlton, Bordieu, Screven, Hooper-Greenhill, Carmen Prats o Eloísa Pérez, entre muchos otros.

Con lo que respecta a España, los estudios de público progresan más despacio en relación a otros países europeos como Francia o Alemania.

El nivel de desarrollo del área ha sido muy bajo y sólo en los últimos años se han empezado a llevar a cabo estudios que puedan denominarse propiamente análisis de público. Entre los más destacados podemos mencionar el llevado a cabo en el año 1995 en el Teatre-Museu Dalí o el realizado en Madrid por Sánchez de Horcajo, Abió, Álvarez, Arraztoa y Corbacho (1997), en el que se presenta un breve perfil sociodemográfico de los visitantes de cinco museos de pinturas, así como los realizados en el Museo Nacional de Ciencias Naturales ${ }^{31}$.

30 Ibídem.

31 PÉREZ SANTOS, Eloisa. Idem. p. 169. 
Se podrían diferenciar claramente dos tipos de estudios de público; los que se concentran en el propio visitante del museo, o aquellos análisis basados en las estrategias y elementos de las exposiciones ${ }^{32}$.

Esta labor de investigación y programación la lleva a cabo el Departamento de Difusión de cada museo. Básicamente su interés en la programación del museo se basa en aumentar el número de visitantes y conocer sus características -ya sean niños, adolescentes, adultos...-, ayudar a estos nuevos usuarios a familiarizarse con los espacios del museo, atenderlos y acogerlos correctamente.

Hoy en día, esta tarea -el estudio del público- ha pasado a ser una actividad esencial del museo y gracias a esta podemos observar que el número de personas que visita y asiste a estas instituciones ha aumentado cada vez más en los últimos años.

Para Eloísa Pérez, en los próximos veinte años, los estudios de visitantes deberán hacer frente a algunos retos importantes, entre ellos la total implantación de nuevas tecnologías en el museo y también la incorporación de éstas al estudio del público, nuevos sistemas de observación, cuestionarios informáticos y desarrollo de métodos de muestreos a través de Internet ${ }^{33}$.

Como podemos ver, los museos han cambiado en dos aspectos importantes; en la tipología de objetos que alberga y en el público - de un visitante pasivo a un público activo-. Este cambio ha provocado además una transformación en la

32 CABALLERO GARCía, Luis. Idem.

33 PÉREZ SANTOS, Eloisa. Idem. p. 224. 
concepción de la exposición y del museo ${ }^{34}$. Esto es importante si se quiere dar una nueva imagen -más atractiva- de la institución.

Cada vez más los museos se están esmerando en planificar actividades para el visitante, cubrir sus necesidades y buscar nuevas alternativas para captar y atraer a nuevos usuarios. Especialmente hay que cuidar y pensar en los más jóvenes y pequeños, ya que serán el público del mañana, y por tanto, hay que acostumbrarlos a visitar estos recintos desde bien temprano.

Y como bien dijo Rivière, el padre de la Nueva Museología, es necesario que el visitante saque provecho del museo... ${ }^{35}$

34 CABALLERO GARCía, Luis. Idem.

35 HENRI RIVÍERE, Georges. La Museología: Curso de Museología, textos y testimonios. Madrid. Akal, 1989. 


\subsection{FUNCIONES DEL MUSEO $Y$ SU MANIFESTACIÓN EN EL} SISTEMA DOCUMENTAL DE MUSEOS (DOMUS)

Según Alicia Quintana ${ }^{36}$, los museos son unos centros de cultura, instituciones públicas al servicio de sus visitantes, que ofrecen una información, un conocimiento y un deleite de sus fondos ${ }^{37}$.

Por tanto, son instituciones de difusión, de enseñanza -ya que informan y comunican al público los fondos de la institución-, de investigación -ya sea de las colecciones o del propio museo-, de documentación de datos e información, de conservación-restauración de las piezas que lo integran, y por último, de administración ${ }^{38}$.

Los museos son instituciones que se encuentran en todos los países del mundo pero poseerán características diferentes según su procedencia.

En un principio el museo tenía como objetivos principales el acopio y la conservación de los bienes que 36 Jefa del Departamento Didáctico-Pedagógico del Museo del Prado de Madrid.

37 QUINTANA, Alicia. "Museos: tipos, funciones y aprovechamiento didáctico". Jornadas celebradas en el Museo Nacional de Mérida. (www.museosabate.com/funciones.htm, el 27 de febrero de 2007, consultado el 17 de junio del 2010).

38 SÁEZ LARA, Fernando. "El museo como centro de investigación". En Curso de Iniciación a la Museología, Centro de enseñanza virtual Liceus. Madrid. Universidad de Alcalá, 2007. 
poseía la institución, pero con el paso del tiempo se han ido incorporando otras actividades y funciones como la investigación, la documentación y en último lugar, la difusión.

Estas funciones (coleccionar, investigar, conservar, documentar, difundir y educar) son unas tareas necesarias e indispensables que debe realizar todo museo, tanto para conservar el patrimonio histórico, cultural y artístico que poseemos, para entenderlo y darlo a conocer a toda la sociedad. Así, los fondos del museo deberán estar enfocados a los ciudadanos, sus espectadores.

Veremos que todas estas funciones están conectadas y relacionadas entre sí.

Comencemos definiendo y comentando brevemente en qué consisten estos conceptos -en siguientes capítulos nos detendremos más exhaustivamente en ellos-para tener un mejor conocimiento del significado de éstos y poder aplicarlos a las funciones del museo.

En primer lugar, la conservación de las piezas de un museo es un trabajo muy complejo que ha requerido bastante tiempo en configurarse. Un concepto que tiene un pasado muy largo.

Desde los comienzos de la historia de la humanidad con las primeras expresiones artísticas, encontramos la preocupación por conservar las obras de arte. En un principio estas labores consistían en tratamientos para su mantenimiento e indicaciones a los artistas sobre los 
materiales que debían emplear primando la calidad y pensando en una mayor durabilidad ${ }^{39}$.

Conservar un objeto significa mantenerlo en buen estado físico el mayor tiempo posible. Además, esta acción implica toda una serie de documentos relativos a la colección como la manera de preservarlos, su catalogación, registro y acopio de estos bienes para asegurarnos que no sufran ningún tipo de daño o deterioro. Así, antes de la intervención sobre la pieza es necesario documentarnos científicamente sobre la misma y los diferentes procesos de conservación-restauración que se realicen posteriormente ${ }^{40}$.

La colección del museo, piezas y objetos que alberga en su interior, es lo más importante que posee la institución su razón de ser-, por lo que se ve en la responsabilidad y obligación de proteger y custodiar para así continuar con la enseñanza y exhibición de éstas a un público generación tras generación.

Más adelante continuaremos hablando de este concepto el objeto de la investigación- por lo que no nos detendremos ahora exhaustivamente en esta función.

39 SEDANO ESPÍN, Pilar. "Montaje y gestión de Departamentos de conservación y restauración". En Actas de los XVI cursos monográficos sobre Patrimonio Histórico (Reinosa, Julio 2005), p. 245 .

40 Las actividades en el taller y laboratorio son realmente esenciales y necesarias tanto en los procesos de la conservación preventiva como los de conservación-restauración de los objetos del museo. Para ello se necesita de un estudio intenso para conocer las herramientas, métodos, materiales y diagnósticos adecuados según cada pieza. 
La investigación tiene como fin ampliar un conocimiento científico, sin perseguir, en principio, ninguna aplicación práctica ${ }^{41}$.

Con lo que respecta a los museos, la investigación consiste en el estudio y análisis de la colección, es decir, conocer profundamente los objetos que la forman. Cuanto mayor sea la información que reunamos y tengamos sobre ésta, mejor serán los resultados de los objetivos que la institución se plantea.

Esta tarea influye además en la función pedagógica, puesto que el público es el beneficiario al recibir esta información. Investigar para que podamos comprender, conservar, difundir y analizar tanto nuestro pasado como nuestro futuro.

En palabras de Karsten Schubert la investigación y conservación no pueden separarse porque la una sin la otra pronto decaería y quedaría anticuada. Sólo conjuntamente tienen sentido ${ }^{42}$.

Es muy importante saber qué tipo de investigación debe realizar un museo y cuáles son sus necesidades, ya que la institución tiene objetos de gran valor cultural, artístico, científico e histórico y su finalidad es la de dar a conocer estos bienes a la sociedad y enriquecerla culturalmente. Por

41 Definición según el diccionario de la Real Academia de la Lengua Española. Vigésima segunda edición (2001).

42 SCHUBERT, Karsten. El museo. Historia de una idea. De la revolución francesa a hoy. Granada. Turpiana, 2008. 
tanto, han de escogerse en función de los intereses y de la identidad de la propia institución.

Los bienes que integran la colección del museo deben estar bien registrados y documentados. Por ello, es necesario reunir toda la información disponible relacionada con las colecciones del museo, ya sean expedientes administrativos, informes de conservación-restauración, documentación de ingresos de nuevas obras o préstamos a otras exposiciones.

En cambio, la difusión es la propagación o divulgación de algo, especialmente de un conocimiento o una noticia ${ }^{43}$. Poner algo al alcance del público. Así, la difusión en los museos se encamina a acercar éstos a la sociedad. Se engloban, por tanto, todas las estrategias que permitan conseguir los objetivos de comunicación, contemplación y educación que plantea la institución ${ }^{44}$.

Todas estas actividades culminan con la exhibición de las piezas. El museo dispone al público su colección -ya debidamente conservada-, y le proporciona información sobre la misma, fruto de sus investigaciones. Así, la colección será el medio de enseñanza. Es una manera de educación teórica que se complementa con la práctica.

Tanto la conservación, como la investigación, documentación y la difusión de la información son unas actividades y funciones fundamentales de las instituciones

43 Definición según el diccionario de la Real Academia de la Lengua Española. Vigésima segunda edición (2001).

44 AA.VV. Difusión y comunicación en los Museos. Ministerio de Cultura, Gobierno de España. (Consultado el 30 de junio de 2010). http://www.mcu.es/museos/CE/Funciones/Difusion/Introduccion.html 
museísticas, ya que a partir de éstas se estudian las colecciones.

Son actividades independientes, con unos instrumentos propios, pero cada una de estas tendrá relaciones estrechas con las demás áreas del museo, ya que estas labores se orientan hacia el objetivo, como hemos comentado, de acercar el museo a la sociedad.

Por otro lado, según la Real Academia Española de la Lengua -en la Vigésima segunda edición- define la documentación como:

Un conjunto de documentos, preferentemente de carácter oficial, que sirven para la identificación personal o para documentar o acreditar algo ${ }^{45}$.

La documentación en el museo engloba tanto los documentos de los fondos de la institución, como aquellos que se puedan producir alrededor de ellos a lo largo del tiempo.

La herramienta que se usa actualmente para estas acciones -y no en todos los museos españoles- es DOMUS.

Se trata de un sistema de documentación desarrollado por el Ministerio de Cultura español -Subdirección General de Museos Estatales y Subdirección General de Tratamiento de la

45 Diccionario editado en el año 2001. 
Información- que se está implantando hoy en día en los museos ${ }^{46}$.

Y, ¿qué es un sistema de documentación?

Un sistema de documentación es un conjunto de instrumentos que tiene como objetivo el impulso y la cooperación a la organización y gestión de la documentación del museo, tanto los fondos museográficos, bibliográficos y documentales, como los fondos de carácter museológico o administrativo que son externos al propio museo. Éstos estarán al servicio de las otras funciones de la institución, como la conservación, investigación y difusión de los fondos, además de la gestión administrativa ${ }^{47}$.

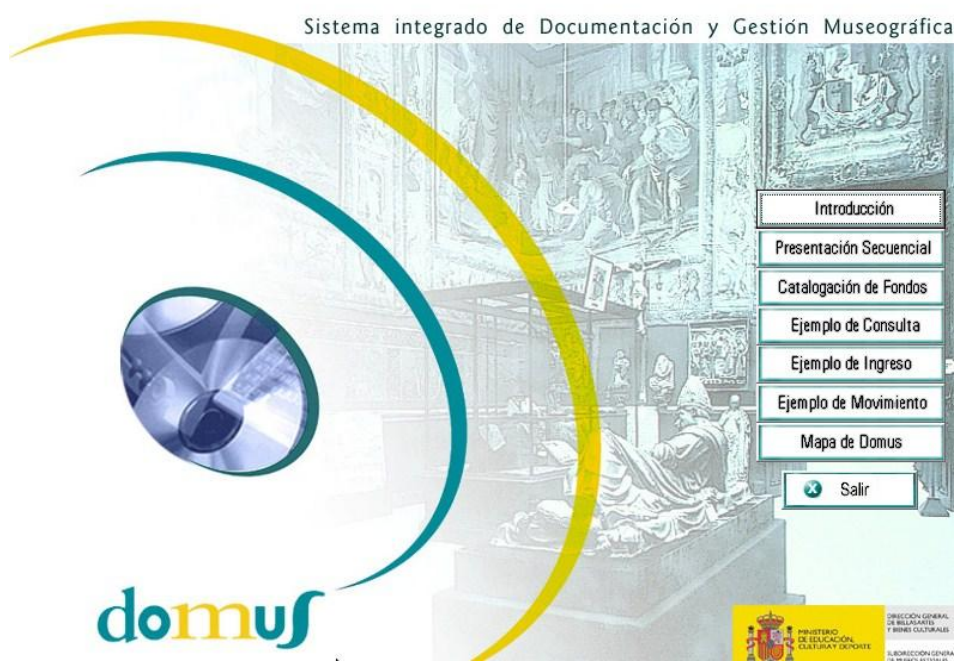

Figura 2. Domus, Sistema integrado de Documentación y Gestión Museográfica

\footnotetext{
46 Domus. Ministerio de Cultura. Dirección General de Bienes Culturales y Bellas Artes. Subdirección General de Museos Estatales. Madrid, 2 de octubre de 2006.

47 Normalización Documental de Museos: elementos para una aplicación informática de gestión museográfica. Ministerio de Cultura. Gobierno de España. Madrid, 1996.
} 
Por tanto, se trata de un sistema informatizado de documentación y gestión museográfica que propone un modelo determinado de documentación de museos. Éstos no sólo deben contener información, sino que también es necesario producirla, conservarla, usarla y difundirla ${ }^{48}$.

La documentación es una ciencia que a través de las técnicas que se denominan documentales (clasificar, difundir, ordenar, coleccionar, seleccionar y recuperar), tienen como objetivo hacer accesible al personal el contenido de las fuentes de conocimiento ${ }^{49}$. En el museo, la documentación comprende una serie de documentos que van desde los propios fondos de la institución a todos aquellos datos que puedan generar alrededor de ellos a lo largo del tiempo. Es decir, pretende recuperar la información.

Se puede ver esta actividad desde dos frentes diferentes; una como el conjunto de documentos que posee un museo y otra como los procedimientos de trabajo que se realiza sobre los diferentes conjuntos de documentos de la institución o en su gestión para cumplir sus funciones.

Para ello se requieren de unos instrumentos simples para examinar y tramitar la información de los fondos del museo y sus movimientos de una manera fácil y evitar complicaciones innecesarias de sistemas complejos que nos impidan un buen funcionamiento del mismo.

\footnotetext{
48 ALQUÉZAR YÁNEZ, Eva Ma . "Domus, un sistema de documentación de museos informatizado. Estado de la cuestión y perspectivas de futuro". En Desde el Museo. Madrid, 1997. p. 30.

49 BRAVO JUEGA, Maria Isabel. "Documentación o investigación". En Museo $\mathrm{N}^{\circ}$ 2, 1997, p. 92.
} 
La Comisión de Normalización Documental de Museos trabajó entre los años 1993 y 1996 en la elaboración de una propuesta de organización de un sistema documental de museos, como base para el desarrollo de una herramienta automatizada de gestión museográfica. Este informe denominado Normalización documental de museos: elementos para una aplicación informática de gestión museográfica, y que se publicó en el año 1996, contiene reflexiones sobre la documentación y la gestión museística, un modelo de organización, así como un análisis funcional y las recomendaciones técnicas utilizadas para el desarrollo del Sistema Integrado de Documentación y Gestión Museográfica DOMUS ${ }^{50}$.

Así, el objetivo de este informe de normalización documental fue la creación de un sistema de documentación como actividad previa a la informatización de los museos, el intercambio y la difusión del conocimiento procedentes de los mismos, que requieren conexión en los sistemas de trabajo y coherencia de la información.

El primer museo que gozó de la implantación de este sistema fue el Museo Nacional de Antropología en la sede Juan de Herrera (Madrid). Se instaló en esta institución en el año 1999 para probar sus funciones y tareas antes de instalarse en el resto de los museos. No se comenzó a incorporar de manera sistemática a las distintas instituciones museísticas hasta el año $2001^{51}$.

50 CARRETERO PÉREZ, Andrés. "Domus y la gestión de las colecciones museográficas". En MARQ, Arqueología y Museos, N 0, 2005, pp. 1730 .

51 Ibídem. 
Entre las actividades que se llevan a cabo con esta nueva herramienta podemos señalar: la informatización de la información de las colecciones, la digitalización de imágenes, el inventario y catalogación de las colecciones en soporte informático, la revisión e informatización de información en soportes manuales y la revisión y depuración de datos informatizados ${ }^{52}$.

Lo que se pretende con esta nueva herramienta informática es que se gestionen y cataloguen los fondos de la manera más eficaz posible. Así mismo, gestionar sus ingresos, registrar, inventariar y catalogar fondos museográficos y documentales, incorporar imágenes digitales en varios formatos al inventario y catálogo de bienes culturales, registrar los informes realizados de restauración y conservación y detallar análisis y tratamientos de restauración de las colecciones del museo. Todos ellos asociados a imágenes digitales de tales procesos de actuación. Sin olvidarnos de especificar la documentación gráfica que está relacionada con los fondos museográficos y documentales, tramitar esta documentación a las personas que la solicitan, gestionar el movimiento de fondos tanto dentro de la institución como fuera de la misma, registrar las entradas temporales de las piezas ajenas al museo, inventariar y catalogar la documentación del archivo administrativo, administrar registros que la administración del museo necesita y dirigir la tienda del museo ${ }^{53}$.

52 Programa de documentación de colecciones. Ministerio de Cultura, Dirección General de Bienes Culturales y Bellas Artes. Subdirección General de Museos Estatales.

http://www.mcu.es/museos/CE/Funciones/Documentacion/DocumenatacionCo lecciones.html (Consultado el 30 de junio de 2010).

53 Domus. Ministerio de Cultura. Idem. 
Como podemos ver, son múltiples las aplicaciones y módulos que lo componen.

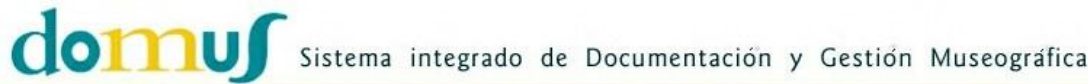
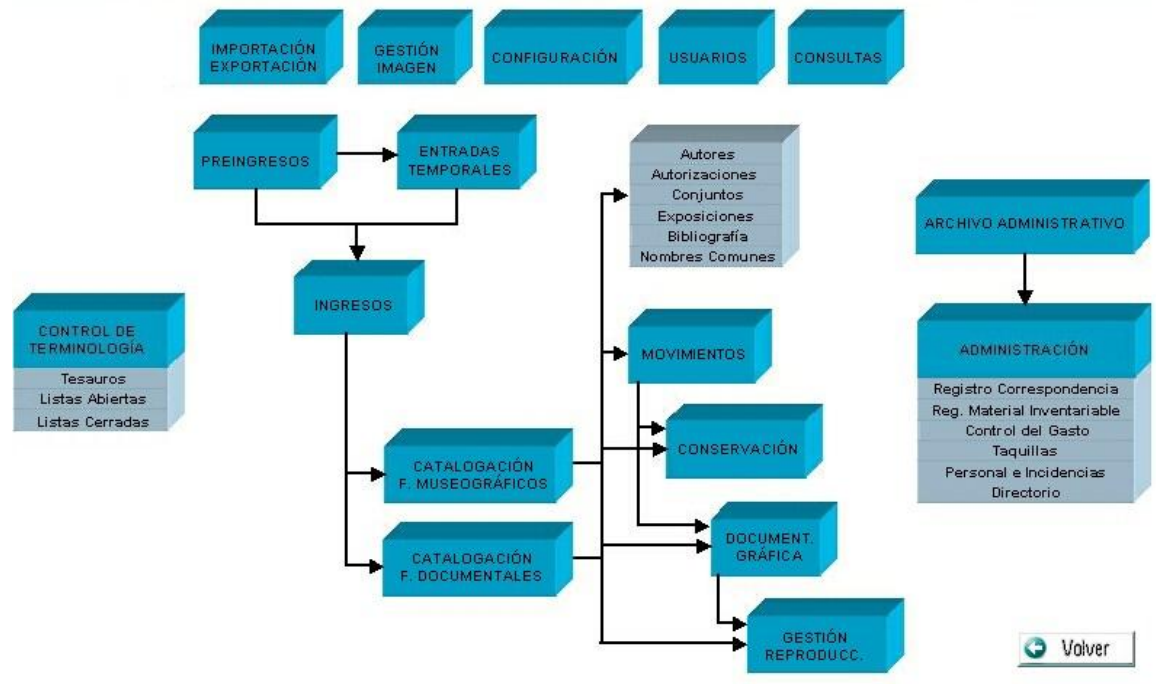

Figura 3. Mapa de Domus

Estas acciones se llevan a cabo en el Departamento Técnico de Documentación del museo, muy importante dentro de la institución, ya que el proyecto Domus es una de las actividades preferentes de la Subdirección General de Museos estatales dentro del Programa de Colecciones del Plan Integral de Museos Estatales. Asimismo está relacionado con el resto de departamentos del museo como son el Departamento de Investigación, el Departamento de Conservación y el Departamento de Difusión.

La incorporación de las nuevas tecnologías a los museos ha modificado muchos de los aspectos de sus formas de 
difusión y comunicación, lo que ha facilitado al ciudadano el acceso a todos los fondos del mismo ${ }^{54}$.

Actualmente se ha implantado una nueva versión de DOMUS, que el Ministerio de Cultura ha desarrollado incorporando interesantes novedades y mejoras con respecto a la anterior versión $3.0^{55}$.

Actualmente son ya numerosos los museos -gestionados por la Subdirección General de Museos Estatales y por el Instituto Nacional de las Artes Escénicas y de la Música- que cuentan con esta útil herramienta de información, y varias las campañas realizadas hasta el momento.

Se encuentran comprometidos en este proyecto 72 museos de distintas titularidades; 18 estatales de gestión exclusiva de la Dirección General de Bellas Artes y Bienes Culturales y del INAEM (Instituto Nacional de las Artes Escénicas y de la Música), 34 estatales de gestión transferida a las Comunidades Autónomas (Andalucía, Galicia, Valencia, Ciudad de Melilla, Aragón, Islas Baleares, Castilla- La Mancha, Murcia, Cantabria y Castilla y León) y 20 de otras titularidades. Por otra parte, los convenios de colaboración

54 Para aquel que esté interesado en ampliar conocimientos en este sistema de documentación se puede consultar una versión "demo" de la aplicación Domus en el portal de museos del Ministerio de Cultura. http://www.mcu.es/museos/CE/Funciones/Documentacion/Documenatacionco lecciones.html.

55 HEREZA LEBRÓN, Pablo, USERO PIERNAS, Victoria, VIlCHEZ MÁRQUez, Estrella. "La calidad como herramienta de implantación de DOMUS en los museos de Andalucía". En Mus-A, N 8, Julio 2007, p. 146. 
firmados contemplan la futura incorporación de otros 201 museos y colecciones de distintas titularidades ${ }^{56}$.

Además, se han firmado varios convenios de colaboración con Comunidades Autónomas -las anteriormente mencionadas- para el apoyo técnico a las instituciones museísticas estatales y de gestión transferida, así como a los museos integrantes de los sistemas de museos autonómicos. Asimismo, se han firmado convenios de colaboración con otras entidades gestoras de museos, como la Fundación Museo Marítimo de la Ría de Bilbao, Fundación Centro Nacional del Vidrio, la Universidad de Valladolid, la Real Academia de Bellas Artes de San Fernando, el Ayuntamiento de San Lorenzo de El Escorial, el Ayuntamiento de Colmenar de Oreja, la Fundación Lázaro Galdiano o la Fundación Foodcultura ${ }^{57}$.

La implantación de DOMUS en los Museos de Andalucía es un claro ejemplo de integración de diferentes equipos y personas en la consecución de un objetivo común. Es el resultado de un complejo trabajo en equipo y de coordinación entre profesionales, museos y administraciones ${ }^{58}$.

\footnotetext{
56 Domus. Estado actual de la implantación. Ministerio de Cultura. Dirección General de Bienes Culturales y Bellas Artes. Subdirección General de Museos Estatales. (Consultado el 30 de junio de 2010). http://www.mcu.es/museos/CE/Funciones/Documentacion/Documenatacionco lecciones.html

57 Ibídem.

58 HEREZA LEBRóN, Pablo, USERO PIERNAS, Victoria, VILCHEZ MÁRQUEZ, Estrella. Idem.
} 


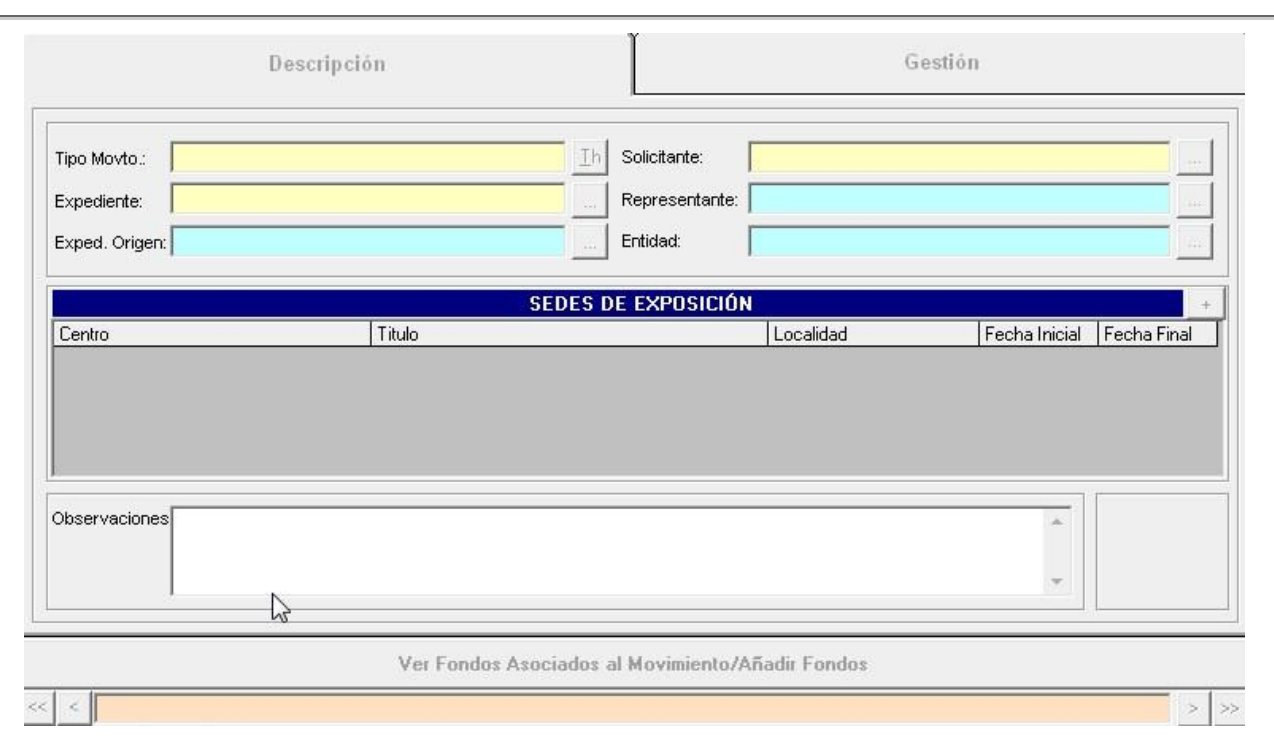

Figura 4. Ficha de movimientos de fondos (Domus)

En el año 2006 se creó una Comisión Técnica de Seguimiento de la Red de Instituciones Usuarias de DOMUS. Esta comisión tuvo como objetivo la coordinación de la utilización de esta aplicación, la realización del catálogo colectivo de museos, y propuso nuevas funcionalidades y mejoras en futuras versiones de DOMUS. Así como formular normas de inventario, catalogación y documentación de las colecciones de los museos, coordinar el Catálogo Colectivo de Museos (Red Digital de Museos), fomentar la Red de Instituciones Usuarias de DOMUS mediante la incorporación de nuevos museos, plantear propuestas y adoptar acuerdos sobre cualquier cuestión que se pueda provocar con relación a la utilización de esta aplicación ${ }^{59}$.

La navegación a través de esta información se realiza mediante unos módulos. El sistema consta del Área de fondos o de Colecciones que tiene los módulos de Catalogación,

59 Comisión de seguimiento de la red de instituciones usuarias de DOMUS. Ministerio de Cultura. Madrid, 2 de octubre de 2006. 
Procesos (ingresos, entradas temporales, movimientos internos y externos, documentación gráfica y conservación), Información relacionada y Consulta ${ }^{60}$.

El Área de administración posee los módulos de Archivo Administrativo, Registro de Correspondencia y Directorio. Y por último, el Área de Sistema incluye los módulos de Tesauros, Listas cerradas, Listas abiertas, Signaturas topográficas, Imágenes, Control de usuarios y Datos de la Institución ${ }^{61}$.

Paralelamente destacan cuatro áreas básicas: Desarrollo informático, Implantación en los museos, Volcado de información, y Normalización y unificación terminológica ${ }^{62}$.

Uno de los fines primordiales del proyecto de Normalización Documental de Museos es la de organizar la terminología, unificarla y estructurar el vocabulario técnico utilizado en la descripción y catalogación de Bienes Culturales.

Para lograr este propósito, la Dirección General de Bellas Artes y Bienes Culturales trabaja en la realización de Tesauros de Patrimonio Cultural. Estos vocabularios, que agrupan diccionario terminológico y la estructura de un tesauro, se pueden clasificar en dos grupos; los diccionarios especializados y los tesauros genéricos.

\footnotetext{
60 CARRETERO PÉREZ, Andrés. Idem.

61 Ibídem.

62 Ibídem.
} 
Los primeros reúnen terminología específica del ámbito temático que le corresponden, estructurándose en varios capítulos. Estos son: Diccionario, Tesauro: estructura jerárquica y cuerpo del tesauro, Modelos de catalogación, Bibliografía básica e Ilustraciones.

La terminología que reúne hace referencia a los aspectos de Denominaciones de objetos y sus componentes, Materias de elaboración y decoración, Técnicas de elaboración y decoración, y Términos de descripción especializados (formales y tipológicos).

Los tesauros genéricos -que llevan desarrollándose desde el año 2002- se centran en la catalogación de todo tipo de Bienes Culturales, ya sean muebles o inmuebles. Incluyen un diccionario terminológico y tesauro.

La terminología reunida en estos tesauros se selecciona en función de su aplicación en varios campos clave en la catalogación y recuperación de información sobre los bienes culturales. Éstos son: Denominaciones de bienes culturales, Materias de elaboración y decoración, Técnicas de elaboración y decoración, Contextos culturales (períodos históricos, estilos artísticos y grupos culturales), Iconografía y Lugares geográficos ${ }^{63}$.

63 Tesauros de Patrimonio Cultural. Ministerio de Cultura. Gobierno de

http://www.mcu.es/museos/docs/Tesauros Patrimonio Cultural.pdf

(Consultado el 30 de junio de 2010). 


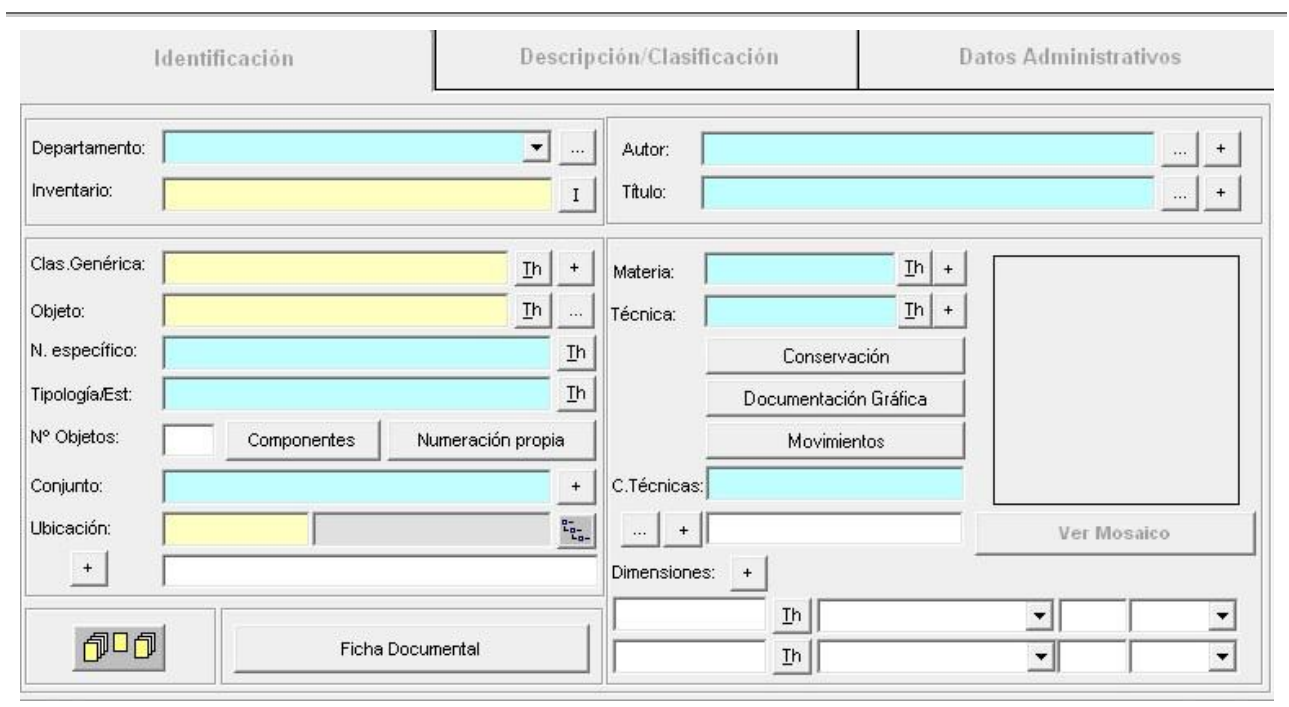

Figura 5. Ficha de catalogación de fondos (Domus)

Existe un proyecto del Ministerio de Cultura, la Red Digital de Colecciones de Museos de España (CER.es, colecciones en Red), que tiene como propósito poner a disposición del público en Internet un catálogo colectivo de los bienes de los museos, tanto de los de titularidad estatal y gestión exclusiva de la Dirección General de Bellas Artes y Bienes Culturales, como los de titularidad estatal y gestión transferida a las Comunidades Autónomas o de los museos de otras titularidades que estén interesados en formar parte de este catálogo.

De la misma manera, permite realizar búsquedas generales y avanzadas en todos los museos o en una selección realizada por el usuario. Es posible consultar en el catálogo de cada uno de los museos o en una o varias agrupaciones por tipología de museo, ubicación geográfica o titularidad ${ }^{64}$.

64 CER.es. Catálogo colectivo de la Red Digital de Colecciones de Museos de España. Ministerio de Cultura. http://ceres.mcu.es (Consultado el 22 de junio de 2010). 


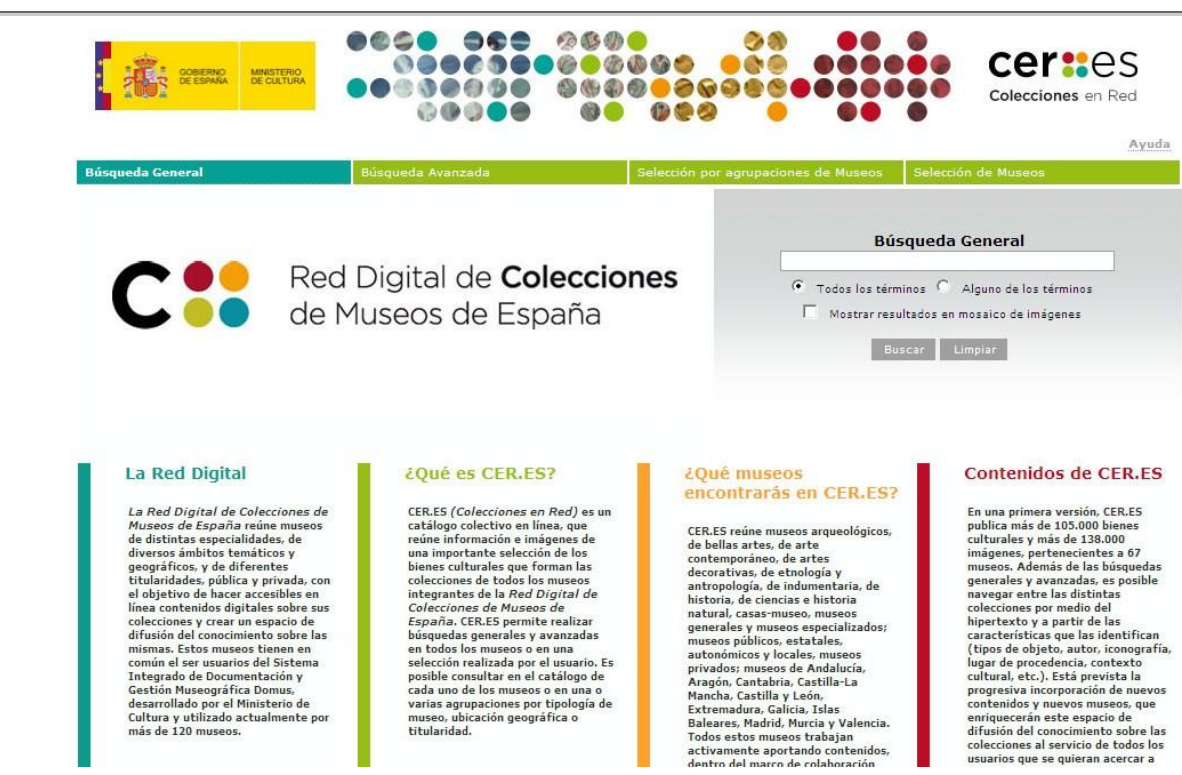

Figura 6. CER.es, Red Digital de Colecciones de Museos de España (Ministerio de Cultura)

Toda la información accesible a través de este catálogo colectivo procederá del Sistema Integrado de Documentación y Gestión Museográfica DOMUS.

El proyecto brindará información descriptiva y de catalogación de las colecciones, además de imágenes digitales ${ }^{65}$.

En la última actualización, realizada a principios del año 2010, publica más de 100.000 bienes culturales y más de 132.000 imágenes pertenecientes a 62 museos ubicados en once Comunidades Autónomas, y es utilizado actualmente por 128

65 Documentación en los museos. Ministerio de Cultura. Idem. 
Los Departamentos de Conservación-Restauración en los museos andaluces: estudio y análisis de casos

museos esperándose la incorporación de otros 207 más adelante ${ }^{66}$.

Por tanto, vemos que se trata de una útil, eficaz y práctica herramienta de trabajo que permitirá un intercambio de información entre las instituciones museísticas.

${ }^{66}$ Ministerio de Cultura. (consultado el 22 de junio de 2010). http://www.mcu.es/novedades/2010/novedades CERES.html 


\title{
4.3. LABOR DE INVESTIGACIÓN, DOCUMENTACIÓN Y DIFUSIÓN EN EL MUSEO.
}

\author{
Es de importancia para quien desee alcanzar una certeza \\ en su investigación, el saber dudar a tiempo.
}

Aristóteles

En el capítulo anterior vimos brevemente en qué consistía cada una de estas tareas, así que ya tenemos una idea del papel que cumple cada una de estas funciones dentro del museo, pero ahora nos detendremos más exhaustivamente en cada una de ellas.

Como ya sabemos, en un principio el museo tenía como objetivos principales el acopio y la conservación de los bienes que la institución poseía. Poco a poco se han ido incorporando otras actividades y funciones, como la investigación, la documentación y en último lugar, la difusión. De tal modo que podemos decir que el fin último común de las dos primeras -la investigación y la documentación- es la difusión del conocimiento.

Este camino ha ido cambiando a medida que evolucionaba el concepto de museo. Gran parte de éstos fueron creados en sus inicios para estar estrechamente relacionados con la actividad investigadora. Pero cada vez más, en estas últimas décadas, los museos se van convirtiendo y transformando en verdaderos centros de participación de la sociedad. 


\section{INVESTIGACIÓN}

La investigación se refiere a estudiar a fondo una determinada materia, es decir, realizar actividades intelectuales y experimentales de modo sistemático con el propósito de aumentar los conocimientos sobre una determinada materia ${ }^{67}$. De tal manera que investigar las colecciones de una institución museística consistirá principalmente en profundizar y conocer los fondos que posee y ponerlos en su contexto. Y, a la inversa, conocer el contexto de referencia, permite determinar, según diferentes criterios, la relevancia de estos objetos -tanto los que se conservan en el museo como los que no- para poder reconstruir el contexto en el museo ${ }^{68}$.

En el tradicional museo, la colección era el foco principal de la labor de los conservadores, un elemento permanente hacia el que estaban dirigidos el estudio, la investigación y la política de adquisiciones ${ }^{69}$.

A partir de la aparición y desarrollo del modelo de museo científico, la finalidad investigadora del mismo ha sido considerada como la más importante, pues se entendía que gracias a ella los objetos cobraban verdadero significado. Esta mentalidad, con sus lógicas adaptaciones, ha regido los

67 Definición según el diccionario de la Real Academia de la Lengua Española. Vigésima segunda edición (2001).

68 SÁEZ LARA, Fernando. "El museo como centro de investigación". En Curso de Iniciación a la Museología, Centro de enseñanza virtual Liceus. Madrid, Universidad de Alcalá, 2007.

69 SCHUBERT, Karsten. El museo. Historia de una idea. De la revolución francesa a hoy. Granada. Turpiana, 2008. 
destinos de la mayoría de nuestros museos hasta hace muy $\operatorname{poco}^{70}$.

La investigación y la documentación de los fondos de un museo son tareas complicadas que habitualmente implican las funciones de registro, inventario y catalogación de las piezas. Así, todos los bienes que entran en una institución deben inscribirse con un número que se le asigna de registro, -que varía en función de su procedencia-, un número de inventario general y los de catálogos. Esto nos permitirá conocer la localización de la obra y evitar posibles pérdidas.

Más adelante, en el apartado de documentación, se ampliarán estos conceptos y acciones; inventariar y catalogar.

Existen tres tipos de investigación en lo que respecta a los museos: las investigaciones realizadas dentro de la propia institución, las realizadas por personal externo a ésta y en las que el museo participa en investigaciones fuera de su institución en temas que están en relación con sus objetivos ${ }^{71}$.

Es un trabajo diario que tiene unos instrumentos propios de carácter analítico (fichas de inventario, catalogación,...) además de sus propias vías de difusión (las exposiciones, catálogos, monografías, publicaciones, boletines, revistas...).

70 SÁEZ LARA, Fernando. Idem.

71 Ibídem. 
La actividad investigadora de un museo debe contener todas las categorías de la institución, como la ampliación de las colecciones, la documentación de los fondos, los programas de conservación y restauración y los programas de difusión. Por lo que es un trabajo interdisciplinar que tiene que estar relacionado con todas las áreas del museo.

En general, este tipo de actividad la lleva a cabo el personal investigador del Departamento Técnico de Investigación -en los museos donde los haya-, el cual posee una gran responsabilidad sobre el conocimiento e interpretación científica de los bienes que pertenezcan al museo $^{72}$. Pero como decimos, no solamente por parte de este Departamento se realiza la labor de investigación, sino que es una tarea conjunta con el resto de departamentos del museo, teniendo cada uno sus propios objetos de investigación, por lo que tiene que acomodarse a las distintas necesidades de la institución.

Así, el trabajo del investigador será: cooperar en los programas de las exposiciones, la catalogación de los fondos, estudiar la historia del museo, su conservación, su público, además de aconsejar y ayudar a adquirir nuevas obras y autentificar colecciones y nuevos materiales, entre otras funciones ${ }^{73}$. Siempre trabajando en colaboración con el resto de los departamentos de la institución.

\footnotetext{
72 Ibídem.

73 Ibídem.
} 
Con lo que respecta a la investigación en conservaciónrestauración y según afirma Ernesto Borelli ${ }^{74}$, hay que destacar, que aunque haya sido un proceso bastante lento, se ha ido asentando una fuerte tendencia a la innovación y a la búsqueda de nuevas aplicaciones y métodos cada vez más avanzados $^{75}$. Muchas de estas nuevas tecnologías no han sido creadas para ser aplicadas específicamente en este campo del conocimiento, sino que procedían del mundo de la ciencia y tecnología, por ello, han sido sometidas a continuos estudios, revisiones, controles y adaptaciones para su posible aplicación en la investigación de la conservación.

Lo que se pretende con estas nuevas herramientas es obtener la mayor cantidad de información posible sin que éstas alterasen, degradasen o modificaran las obras a analizar y estudiar.

Hoy día estas nuevas tecnologías han aportado y ayudado en gran medida la investigación en conservación de bienes culturales, animando a multitud de expertos de diferentes disciplinas a continuar indagando en este complejo mundo y construyendo así un campo interdisciplinar.

Como afirma Fernando Sáez, del Departamento de Investigación del Museo Nacional de Artes Decorativas de Madrid, todos los departamentos deben conocer las

74 Coordinador del Laboratorio del ICCROM (Centro Internacional para el Estudio de la Preservación y la Restauración del Patrimonio Cultural).

75 BORELLI, Ernesto. "Investigación y nuevas tecnologías: consideraciones críticas". En Actas del I Congreso del GEIIC. Conservación del Patrimonio: evolución y nuevas perspectivas. 25, 26 y 27 de noviembre de 2002 . 
investigaciones que en su campo se realizan en otros museos y centros de apoyo, la teoría general y las aplicaciones y experiencias ajenas y estudiar cómo beneficiarse de todo ello al servicio de los fines propios y de los del museo como conjunto ${ }^{76}$.

En conclusión, el museo se debe organizar y estructurar como un conjunto de funciones que deben estar bien equilibradas entre ellas, además de estar bien planificadas sus interrelaciones y el papel de cada departamento ${ }^{77}$.

\section{DOCUMENTACIÓN}

En el capítulo anterior hemos explicado las funciones del museo y su relación con el sistema documental Domus. Aquí podemos aclarar que la documentación en el museo es el tratamiento de los datos que existen en la institución ${ }^{78}$.

Para Stuart A. Holm, especialista en Documentación de Colecciones de Museos y Patrimonio, la documentación de colecciones es;

Toda la información registrada que un museo posee respecto a los bienes que custodia. También contempla la actividad de recogida, almacenamiento, manipulación y recuperación de esa información (...). Permite una adecuada gestión, comprensión e

\footnotetext{
76 SAEZ LARA, Fernando. Idem.

77 Ibídem.

78 MARÍN TORRES, Ma Teresa: Historia de la documentación museológica: la gestión de la memoria artística. Gijón. Trea, 2001.
} 
interpretación de las colecciones del museo, ahora y en el futuro ${ }^{79}$.

Desde el año 1800, la documentación de los fondos de un museo ha sido una necesidad muy demandada. Pero hasta cien años después, en 1900, esta documentación no se une con la función de investigación, que consistía en el inventario de los objetos y en su clasificación de acuerdo a los criterios taxonómicos primero (bronce, hierro, vegetales, minerales...) e histórico-culturales (íbero, romano...) que procedían de la investigación empírica y positivista ${ }^{80}$.

En este mismo año aparecen por vez primera los conceptos propiamente documentales de inventario y catálogo. Como afirma Luis Caballero, el Reglamento de 1901 obliga a los museos dependientes de la Dirección General de Bellas Artes -concretamente a los jefes de sección- a inventariar y catalogar las piezas, informando al Ministerio del progreso de los trabajos. Aparecen así identificados por primera vez los instrumentos documentales. Sin embargo, su función no quedaba perfectamente explicitada ${ }^{81}$.

En España, la historia de la documentación aplicada a los museos ha sido un tanto debatida y compleja destacando que la gran mayoría de la bibliografía que hay publicada al

79 HOLM, stuart A. Facts \& Artefacts. How to document a museum collection. Cambridge, Museum Documentation Association, 1991. p. 2. 80 CABALLERO GARCíA, Luis. "El sistema de documentación en el museo". En Curso de Iniciación a la Museología, Centro de enseñanza virtual Liceus. Madrid, Universidad de Alcalá, 2007.

81 Ibídem. 
respecto trata sobre los problemas que plantea la redacción de los catálogos ${ }^{82}$.

Joaquín $\mathrm{M}^{\mathrm{a}}$ de Navascués ${ }^{83}$ y Luis Caballero Zoreda ${ }^{84}$ desarrollaron el sistema documental anteriormente mencionado -de expediente-, identificando sus instrumentos y las interrelaciones entre ellos ${ }^{85}$.

Y, ¿qué es el inventario y el catálogo de un museo?

Son dos conceptos que están estrechamente relacionados y por tanto hay que saber distinguirlos y diferenciarlos.

En palabras de Maria Isabel Bravo ${ }^{86}$, el inventario es un instrumento de descripción y recuperación de la información en un orden numérico ${ }^{87}$. Es decir, el listado completo de todas las obras que pertenecen al museo, por lo que su fin será registrar todas las piezas que pertenezcan a éste. En cambio, el catálogo es la ordenación de los datos de la institución.

82 BARRACA DE RAMOS, Pilar. "Algunos aspectos de la documentación en los Museos". En ANABAB, Tomo 44, $\mathrm{N}^{\circ} 1,1994$, pp. 135-151.

83 Para mayor información, consultar el documento de Navascués, Instrucciones para la redacción del inventario general, catálogos y registros en los museos servidos por el Cuerpo Facultativo de Archiveros, Bibliotecarios y Arqueólogos, donde se hace referencia al empeño de los conservadores de los museos por lograr una norma general, además de los desacuerdos aparecidos en el método de trabajo.

84 Conservador de Museos Estatales e Investigador del Consejo Superior de Investigaciones Científicas.

85 CABALLERO GARCíA, Luis. Idem.

86 Perteneciente a la Subdirección General de Difusión y Acción Cultural, Ministerio de Defensa.

87 BRAVO JUEGA, Maria Isabel. "Documentación o investigación". En Musa, $\mathrm{N}^{\circ}$ 2, 1997. p. 92. 
Un instrumento de recuperación de la información según una clasificación preestablecida (cronológico-cultural, genérica, por autores... $)^{88}$.

El inventario puede constar de varios apartados; número de inventario, descripción morfológica de la pieza, procedencia, forma y fecha de ingreso, referencia topográfica, número de catálogo sistemático, número de catálogo monográfico ${ }^{89} \ldots$

Ambos instrumentos tanto el inventario como el catálogo son necesarios en todo museo, ya que forman parte del proceso documental de los fondos del mismo. El investigador se encargará de cumplimentar los datos del inventario y el documentalista será el responsable de completar los campos del catálogo, por lo que deberá poseer un conocimiento general de la colección.

El primero interviene actualizando y enriqueciendo los datos de los instrumentos documentales y el documentalista facilita el control permanente de los fondos ${ }^{90}$. Sus funciones básicas consistirán en organizar y gestionar el sistema documental del museo, la biblioteca y archivos documentales, controlar y gestionar los movimientos de las obras -tanto externos como internos-, registrar e inventariar los bienes, archivar la documentación, además de asesorar e informar a

\footnotetext{
88 Ibídem.

89 GARCía CANO, José Miguel. "La documentación en el Museo Arqueológico de Murcia". En Anales de documentación, N² 2, 1999. p. 161.

90 BRAJO JUEGA, María Isabel. "Documentación o investigación". En Museo $\mathrm{N}^{\circ} 2,1997$.
} 
investigadores, profesionales o a cualquier otro público sobre su área encargada en el museo ${ }^{91}$.

Para ello se deberá conocer, investigar y estudiar científicamente las piezas del museo para poder catalogarlas correctamente y así poder difundirlas de una forma adecuada.

Estas acciones de inventariar y catalogar -junto con la de registro-, se llevan a cabo en el museo para comprobar y controlar los objetos y piezas del mismo, por lo que son unas herramientas de trabajo internas a la institución ${ }^{92}$.

Los datos obtenidos son privados y no todo el mundo tendrá acceso a los mismos, a no ser que se solicite previamente la consulta y se acepte al investigador.

Así el Real Decreto 620/1987, del 10 de abril, por el que se aprueba el Reglamento de Museos de titularidad estatal y del Sistema Español de Museos, enuncia:

Los museos deberán facilitar a los
investigadores la contemplación y estudio de los
fondos que no estén expuestos al público, así como
la consulta de todos los catálogos sin menoscabo del
normal funcionamiento de los servicios ${ }^{93}$.

91 CABALLERO GARCía, Luis. Idem.

92 BARRACA DE RAMOS, Pilar. Idem.

93 Real Decreto 620/1987, de 10 de abril, por el que se aprueba el Reglamento de Museos de titularidad estatal y del Sistema Español de Museos. Artículo 23 (acceso para investigadores), título I. 
Como ya sabemos, la documentación se lleva a cabo en el Departamento de Documentación, y según Pilar Barraca ${ }^{94}$, las funciones básicas de éstos son:

- La coordinación y gestión de todos los catálogos documentales del museo.

- La custodia y clasificación de la documentación referida a los objetos museísticos.

- Promover la existencia de fondos documentales o archivos documentales con diferentes soportes, de contenidos afines a los del museo.

- La catalogación y clasificación de los fondos documentales.

- La promoción de los supuestos centros de documentación e investigación que existen en todos los museos y que se expresan materialmente en las bibliotecas especializadas ${ }^{95}$.

Pero estas acciones dependerán de cada museo, ya que no existe un esquema organizado para todas las instituciones que agrupe las necesidades y sistemas de trabajo que poseen en la actualidad. Aunque sí se muestra un interés en todos los museos por incorporarse a los nuevos procesos para los sistemas documentales ${ }^{96}$.

En este punto debemos hacer referencia a los soportes informáticos, que han facilitado y aligerado una serie de labores internas del museo. Un ejemplo es la documentación y catalogación, que ahora se puede hacer compartida con otras

\footnotetext{
94 Personal del Museo Arqueológico Nacional, Madrid.

95 BARRACA DE RAMOS, Pilar. Idem. p. 138.

96 Ibídem.
} 
instituciones, lo que permite mejorar y agilizar estas actividades.

Así pues todo debe quedar correctamente documentado para las futuras generaciones.

\section{DIFUSIÓN}

La difusión es la actividad que se encarga de relacionar la sociedad con el museo, de transmitir al visitante sus objetivos y contenidos de las colecciones y la que permite propagar el mensaje que el museo quiere transmitir. Es una tarea que depende, y está relacionada, con otras funciones que se desarrollan en la institución.

¿Cómo propagar la información y qué información?

Todo museo debe elaborar estrategias de comunicación para informar a la sociedad de sus servicios y programas: actividades, exposiciones, eventos, cursos... y al mismo tiempo que el público pueda opinar y valorar sobre la visita a la institución.

Pero no sólo la comunicación con el exterior es importante, la comunicación dentro del propio organismo es un hecho imprescindible para que la organización de éste sea lo más lógica posible.

La misión de los Departamentos de Difusión, -según los denominen en cada museo- es la de estudiar y conocer las necesidades y características de su público. Investigar sobre el visitante del museo y definir sus necesidades, intereses, sus conocimientos previos a la visita, sus expectativas... Igualmente, estudiar los medios de comunicación y de difusión de las exposiciones del museo, colaborar en las exposiciones 
que llevan a cabo los departamentos responsables y evaluar la incidencia de éstas en el visitante. Gestionar y organizar actividades culturales, planes de publicaciones, investigar sobre técnicas museográficas, e incluso ayudar a otros museos en sus programas de investigación ${ }^{97}$.

Básicamente su interés en la programación del museo se basa en aumentar las visitas de público, definir un determinado tipo de visitantes (ya sean niños, adultos...) y ayudar a estos nuevos usuarios a familiarizarse con los espacios del museo. Enseñar deleitando que es, al fin y al cabo, la finalidad última del museo ${ }^{98}$.

Un correcto trabajo de difusión ayudará a que aumenten las visitas al museo y mejorará al mismo tiempo la calidad de tal experiencia. De igual modo, dará a conocer -a través de diferentes medios- la existencia de los museos y colaborará con otras instituciones para trabajar colectivamente y compartir experiencia y saber.

En la actualidad, Internet es una herramienta de difusión realmente útil para dar a conocer a la sociedad el trabajo que están llevando a cabo los museos, por lo que es necesario comentar brevemente la influencia e importancia que ha tenido esta en nuestro Patrimonio.

Internet es la mayor red de comunicación del mundo de ámbito global y accesible al público, que ofrece una gran

97 CABALlero GARCíA, Luis. "El público en el Museo: sistemas de evaluación". En Curso de Iniciación a la Museología, Centro de enseñanza virtual Liceus. Madrid. Universidad de Alcalá, 2007.

98 RAVÉ PRIETO, Juan Luis. "Educación en los Museos". En Mus-A, Nº 6, Abril 2006. p. 31 . 
cantidad de servicios en un espacio virtual donde nos podemos comunicar, buscar y transferir información sin grandes requisitos económicos ni tecnológicos. Por ello, muchos lo denominan La Autopista de la Información, una red donde se difunde continuamente increíbles cantidades de información.

Difundir información en Internet es una actividad cada vez más frecuente entre nosotros gracias a los grandes avances de la ciencia en los últimos años, lo que nos permite transmitir una información -que debe ser de calidad y actualizada- a toda la población.

Este avance ha mejorado las herramientas utilizadas en muchos campos del conocimiento, uno de ellos es el relacionado con el mundo museístico y de los Bienes Culturales.

Un ejemplo claro es que Internet ha sustituido a las típicas publicaciones en formato papel que el museo estaba acostumbrado a divulgar, con la gran ventaja de que permite una difusión global. De tal manera que el usuario -ya sea un simple navegante o un investigador- podrá acceder a un sinfín de útil información: fuentes bibliográficas, colecciones de museos, trabajos de conservación y restauración, normativas, empresas... de una manera fácil y rápida.

Asimismo, con esta nueva forma de difusión, se han incrementado las visitas del público al museo y se ha impulsado a que estos usuarios participen más activamente en las actividades que el museo les oferte.

Como vemos, la incorporación de las nuevas tecnologías a los museos ha modificado muchos de los aspectos de sus formas de difusión y comunicación. 
En este contexto también hay que destacar que Internet ya no sólo es una herramienta que difunde los museos y las colecciones existentes en la actualidad, sino que además ha favorecido la creación de nuevos tipos de museos, como son los museos digitales y los virtuales.

Museos que pueden favorecer el incremento de visitas al museo tradicional, al ser éstos una primera aproximación a la experiencia museística.

Sergio Talens ${ }^{99}$ y José Hernández ${ }^{100}$ definen así los museos virtuales:

Los museos virtuales reciben fundamentalmente esta denominación porque suelen copiar los contenidos de algún otro museo real, siguen la obra de algún artista o tratan un tema especial. Aunque los museos virtuales no reemplazarán nunca las visitas físicas para ver los originales de obras históricas para la humanidad, cuando la distancia o las posibilidades económicas no permiten ir, siempre pueden ser una opción muy válida para un primer acercamiento, de una forma más próxima (virtual) a lo que sería la verdadera visita ${ }^{101}$.

\footnotetext{
99 Director del Área de Sistemas, Seguridad y Software Libre del Instituto Tecnológico de Informática, Valencia. 100 Profesor Titular de la Escuela Técnica Superior en Ingeniería Informática. Universidad Politécnica de Valencia (Departamento de Sistemas Informáticos y Computación).

101 Citado por $\mathrm{M}^{\mathrm{a}}$ Luisa Bellido en Museos virtuales y digitales, http://museosvirtuales.wordpress.com/2009/02/04/museos digitales/, 4 de febrero de 2009. (Consultado el 30 de junio de 2010).
} 


\section{LA CONSERVACIÓN PREVENTIVA}

Este capítulo se inicia comentando brevemente el origen de la conservación del Patrimonio para adentrarnos posteriormente en la conservación preventiva en el museo, por lo que explicaremos la conservación de movimientos de obras, la conservación en almacenes y espacios expositivos, y la seguridad, conservación y áreas espaciales en los museos.

\subsection{EL ORIGEN DE LA CONSERVACIÓN DEL PATRIMONIO}

El patrimonio de un país es por esencia su identidad cultural, ya sea grande o pequeño, majestuoso o sencillo, material o inmaterial, debe ser conservado y tener un significado para las generaciones futuras.

Ieoh Ming Pei ${ }^{102}$

En primer lugar es necesario detenernos un instante en el significado de la palabra "conservación". El propósito de "conservar" no es sólo proteger nuestro Patrimonio para transmitirlo a generaciones venideras, sino que además es crear las condiciones idóneas para las piezas minimizando de esta manera el riesgo de deterioro.

La conservación y la restauración han estado ligadas a los cambios de la sociedad y se han visto influidas y

102 Arquitecto estadounidense de origen chino. 
condicionadas por la ideología y las necesidades sociales y culturales del momento103.

El Patrimonio es otro concepto que hay que conocer para poder entenderlo.

Se trata de un concepto muy amplio y un hecho complejo que ha supuesto una gran revolución cultural, política y jurídica. Es la aportación y la huella que ha ido dejando cada sociedad a lo largo de la historia, ya que las manifestaciones de una sociedad a lo largo del tiempo son muy numerosas y variadas ${ }^{104}$.

Ante esto nos preguntamos, ¿cuándo aparecen las primeras acciones de conservación del Patrimonio en la historia de la humanidad?

Desde la Prehistoria ya se confirma que el ser humano agrupaba sus objetos (huesos, piedras...) para clasificarlos y coleccionarlos. Pero con el paso de los siglos este afán coleccionista va en aumento. Un ejemplo lo encontramos en la civilización egipcia y en el Próximo oriente, donde se recogían y recolectaban objetos preciosos ligados a los templos, además de saquear y expoliar tumbas reales.

En Grecia y Roma aparece un gran interés por la conservación de las piezas, asimismo surge el fenómeno de los

103 MACARRÓN MIGUEL, Ana Ma . Conservación del Patrimonio Cultural. Criterios y normativas. Madrid. Síntesis, 2008. p. 57.

$104 \mathrm{AA}$. VV. "Teoría de la conservación y restauración del Patrimonio Cultural". En Curso de Iniciación a la Conservación del Patrimonio, Centro de enseñanza virtual Liceus. Madrid. Universidad de Alcalá, 2007 . 
Tesoros (Thesauros) creando un inventario de los mismos para cerciorarse de su control.

Pero será en el mundo helenístico donde surjan las colecciones privadas a manos de personas adineradas. De igual modo aparecerá el profesional que se ocupe de adquirir las obras para el coleccionista, el marchante.

Posteriormente, lo que destacará en la época medieval serán las colecciones de tipo religioso, ya que la religión es un factor muy importante durante este periodo. Así, entrada la Edad Media, probablemente lo más destacado en cuanto al coleccionismo se refiere es la participación de la Iglesia en el atesoramiento para los fieles, y por otro, en codiciados botines de las Cruzadas ${ }^{105}$.

Esto es lo que dará lugar años después a la creación de los museos eclesiásticos. Pero será en el Renacimiento donde este concepto de colección religiosa se modifique.

A finales de este periodo empiezan a aparecer una serie de documentos y normativas encaminadas a proteger los bienes de las destrucciones y expolios de las colecciones reales y la Iglesia ${ }^{106}$.

Al volver a valorarse lo clásico (griego y romano) comienza a apreciarse la obra como algo de valor estético y de deleite. Ahora la colección tendrá un cierto prestigio, será mucho más especializada y erudita, convirtiéndose al

105 MONTAÑÉS, Carmen (coord.). El museo. Un espacio didáctico y social. Madrid. Mira editores, 2001. p. 21. 106 MACARRÓN MIGUEL, Ana Ma. Idem. p. 49. 
mismo tiempo en un documento histórico al tenerse conciencia de que esta forma parte de una civilización del pasado.

Pero la conservación renacentista está llena de contradicciones, ya que se caracteriza por el mecenazgo y la protección de las artes y restos antiguos, pero al mismo tiempo se originan destrucciones y actuaciones de adaptación y reutilización de edificios antiguos ${ }^{107}$.

A raíz de esta nueva concepción, las colecciones se irán abriendo cada vez al público para que puedan ser disfrutadas.

Será Cosimo de Médicis ${ }^{108}$ el primer coleccionista de obras que llame a su colección privada como "museión". Por tanto vemos que estas colecciones están en los orígenes de los futuros museos.

En la Europa del siglo XVI, en plena Reforma protestante, se está viviendo un momento en el que cada estado, por vez primera, se está interesando en buscar su historia. Se comienza a estudiar los monumentos de la nación y a catalogar e inventariar los distintos objetos y bienes que pertenecen a su Patrimonio. Se forma así lo que dará personalidad y carácter a cada país y de este modo distinguirse del resto de las naciones.

Al mismo tiempo surgen los primeros anticuarios (en Inglaterra ${ }^{109}$ ), donde se comienza a estudiar y conservar las

107 Ibídem.

108 Político italiano, banquero, fundador del mecenazgo de los Médici y amante de las ciencias y el arte.

109 En 1572 se crea la primera sociedad de anticuarios en Londres. 
distintas antigüedades que posee el país, por lo que se puede decir que empiezan a crearse y publicarse las primeras leyes de conservación de los materiales, tratados y libros donde se detallan e inscriben estos objetos antiguos.

Los descubrimientos arqueológicos de Pompeya y Herculano junto con la creación de las Academias y los museos, jugarán un papel fundamental en la conservación y protección del Patrimonio. Así, a raíz de la Revolución Francesa, las colecciones de arte se nacionalizan, pasando a tener un carácter público, y por tanto, su protección a todos los niveles será de responsabilidad estatal ${ }^{110}$.

El Patrimonio hasta este momento estaba acaparado por la realeza y la aristocracia, pero a partir de estas fechas se comienza a considerar un Patrimonio que pertenece a una nación, abriendo poco a poco sus puertas a la población.

La gran cantidad de excavaciones arqueológicas que se realizan en este momento influirán tanto en el pensamiento como en el coleccionismo de las obras. Surge la necesidad de organizar las colecciones de forma científica, las piezas son valoradas como documentos de la Historia y se plantea la apertura de las colecciones al público para ejercer la función pedagógica ${ }^{111}$.

A partir de este momento proliferarán los gabinetes y museos, en concreto los de Historia Natural y Arqueológicos. En 1735 se creó el Museo Británico (Inglaterra) pero no abrió

\footnotetext{
110 MACARRÓN MIGUEL, Ana Ma . Idem. p. 51.

111 "Historia del Museo". en Revista Digital Nueva Museología. Ww. nuevamuseologia.com.ar/historia del museo.htm (consultado el 7 de julio de 2010).
} 
sus puertas al público hasta veinticuatro años después, en 1759. En Francia se abrió el Museo Central de las Artes (Louvre) en 1793.

El hecho de coleccionar objetos se convierte en una actividad tan corriente que en 1727, Caspar Frederich Neickel ${ }^{112}$ publica el primer tratado sobre Museografía, Museographia u orientación para el adecuado concepto y conveniente colocación de los museos o cámaras de curiosidades. Un libro escrito en latín donde da consejos de cómo organizar, conservar las colecciones y realizar un gabinete o un museo ideal.

En lo que respecta a España, Carlos III fundará en 1771 el Real Gabinete de Historia Naturali13, una gran colección de piezas pertenecientes al reino natural además de otros objetos procedentes de diversas partes del mundo. En otras ciudades como Ámsterdam o Estocolmo ya existían este tipo de gabinetes.

Otro dato importante a tener en cuenta es la creación, a finales de este siglo, de las Reales Academias de Bellas Artes -instituciones muy asociadas a las colecciones- y las primeras escuelas de restauradores, motivo para que el Estado se encargue de la protección y salvaguarda del Patrimonio. Por lo que se comienza a propagar la idea de que el Patrimonio ha de ser colectivo.

Será el momento de ir adquiriendo conocimientos en causas de deterioro y comportamiento de los diferentes materiales. Asimismo, se darán otros cambios que tendrán una

\footnotetext{
112 Marchante de obras.

113 Hoy Museo Nacional de Ciencias Naturales, Madrid.
} 
repercusión importante en la formación de la conservación preventiva ${ }^{114}$.

Por tanto, en los siglos XVII y XVIII se producirán grandes cambios en el Patrimonio. Es con la llegada de la Ilustración cuando comienza a hacerse público, y a partir de finales del XVIII, éste comienza a tener una importancia política y artística.

Hay que destacar que la Revolución Francesa trajo consigo grandes cambios y consecuencias para el Patrimonio. Las desamortizaciones que se produjeron en los bienes que pertenecían a la Iglesia, la nobleza y monarquía hicieron que éstos formaran parte del Estado. Al mismo tiempo se destruyeron y deterioraron numerosos edificios y monumentos, por lo que comienza a interesar restituir parte de estas construcciones.

Otro factor clave para el desarrollo de la conservación, como ya se ha comentado, son las excavaciones y descubrimientos arqueológicos efectuados en el siglo XVIII, lo que dará lugar a mediados del siglo XIX al nacimiento de la conservación y la restauración como una disciplina científica.

A finales del siglo XVIII se amplía el concepto de Patrimonio Cultural colectivo, que se extiende a las Artes Aplicadas y Decorativas y a la Arqueología Industrial.

114 BRUQUETAS GALÁN, Rocío. "La conservación preventiva: una nueva profesión con una vieja historia". http://ge-iic.com/ (consultado el 7 de julio de 2010). 
Otro hecho importante es la incorporación de los talleres de restauración y los laboratorios de análisis químicos a los museos, lo que favorece la investigación en el estudio histórico-artístico de la obra y en las intervenciones restauradoras, que tienden a ser más científicas y respetuosas con el original ${ }^{115}$.

Al tener esta nueva concepción de valorar los objetos históricos que pertenecen a una civilización, irán surgiendo y apareciendo nuevas leyes, sanciones y un órgano administrativo y jurídico -que anteriormente no existíanpara vigilar, estudiar, conservar y difundir estos bienes. De igual manera se obliga a la realización de inventarios y recopilación de todo el Patrimonio del pasado, ya que se trata de objetos de un gran valor económico, cultural, tradicional, emocional y religioso. Es un patrimonio irremplazable que pertenece a toda la sociedad y por tanto hay que velar por su seguridad y conservación.

Así, en el siglo XIX se sientan las bases para la investigación teórica sobre el museo. Se dan los primeros intentos de establecer los principios de la museología, considerada como disciplina científica para estudiar la teoría y el funcionamiento de los museos, definida como ciencia de la organización, conservación y presentación de los objetos en los museos ${ }^{116}$. Esto dará lugar a la creación de numerosas instituciones -públicas y privadas-, sociedades,

\footnotetext{
115 MACARRÓN MIGUEL, Ana Ma . Idem. p. 53.

116 GARCÍA SERRANO, Federico. "Museología, soporte teórico a la investigación del museo".

http: //correodelasculturas.wordpress.com/2008/07/28/museologiasoporte-teorico-a-la-investigacion-del-museo/ (Consultado el 16 de julio de 2010).
} 
documentos, normas, leyes, congresos... con el fin de conservar y legislar el Patrimonio.

Un ejemplo a destacar es la creación de las Comisiones de Monumentos Históricos que, a partir de 1830, se difunden por toda Europa. Se encargan de inventariar el Patrimonio edificado y de promocionar políticas de restauración ${ }^{117}$. Como vemos, se irá institucionalizando el Patrimonio.

En España, aunque se habían estado realizando restauraciones durante el siglo XIX, no es hasta el siglo XX cuando aparece un verdadero pensamiento restaurador ${ }^{118}$.

Durante este tiempo se alimentó de teorías de otros países, como las de Violet-le-Duc y Camilo Boito. Pero aparecen dos corrientes enfrentadas: la escuela conservadora y la escuela restauradora. Ésta última estaba integrada por arquitectos como Vicente Lampérez ${ }^{119}$, Ricardo Velázquez Bosco ${ }^{120}$ o Demetrio de los Ríos y Serrano ${ }^{121}$. Todos ellos

117 "Conceptos de Patrimonio". En Revista Digital Nueva Museología. http://www.nuevamuseologia.com.ar/patrimonio2.htm (Consultado el 7 de julio de 2010).

118 AA. VV. Idem.

119 LAMPÉREZ Y ROMEA, Vicente. "Los comienzos de la arquitectura ojival en España". En Boletín de la Sociedad Española de Excursiones, Vol. 10, No 113, 1902, pp. 150-152. Ver también "Notas sobre algunos monumentos de la arquitectura cristiana española". En Boletín de la Sociedad Española de Excursiones, Vol. 11, $\mathrm{N}^{\circ} 124$, 1903, pp. 131-135.

120 VELÁzQUez BOSCO, Ricardo. Excavaciones en Medina Azahara: Memoria sobre lo descubierto en dichas excavaciones. Madrid, 1923 e Informes acerca del estado de la Alhambra. Granada, 1914.

121 DE LOS RíOS Y SERRANO, Demetrio. La Catedral de León. Madrid, 1895 . 
seguidores de la restauración estilística de Viollet-le-Duc. Formaban parte de la escuela conservadora Torres Balbás ${ }^{122}$, Jeroni Martorell i Terrats ${ }^{123}$ o Josep Puig I Cadafach ${ }^{124}$. Dos posturas que se dirigen a alcanzar un punto intermedio, la restauración científica ${ }^{125}$.

En cuanto a las destrucciones de nuestro legado cultural, lo que ha ocasionado a lo largo de los siglos graves pérdidas y desapariciones en el Patrimonio han sido los numerosos botines y saqueos provocadas por las guerras.

A raíz de estas acciones se realizó una conferencia internacional en 1954, la Convención de la Haya, para proteger los Bienes Culturales en caso de Conflicto Armado. Esta introdujo el concepto de "Bien Cultural", bienes que, con independencia de su noción y configuración descriptiva, suelen estar constituidos por los más relevantes testimonios y manifestaciones corporales e incorporales de la actuación de una sociedad a lo largo de la historia, y cuya protección,

122 TORRES BALBÁS, Leopoldo. "La conservación y la destrucción de las murallas". En Castillos de España: publicación de la Asociación Española de Amigos de los Castillos, No 74, 1972, pp. 12-16 y "El tradicionalismo en la Arquitectura española". En Arquitectura: órgano de la Sociedad Central de Arquitectos, $N^{\circ}$ 6, 1918, pp. 176178.

123 MARTORELL I TERRATS, Jeroni. "El urbanismo en relación a los monumentos arqueológicos". En II Congreso de Arquitectos de Lengua Catalana. Barcelona, 1935.

124 PUIG I CADAFALCH, Josep. Josep Puig i Cadafalch: I'arquitectura entre la casa $i$ la ciutat = architecture between the house and the city: Barcelona 4 de desembre de 1989-11 de febrer de 1990. Barcelona, 1989. 125 AA. VV. Idem. 


conservación y fomento contribuirá a engrandecer el
patrimonio común de la humanidad ${ }^{126}$.

Es decir, según esta Convención, se considerarán como Bienes Culturales cualquiera que sea su origen y propietario:

\begin{abstract}
a) Los bienes, muebles o inmuebles, que tengan una gran importancia para el patrimonio cultural de los pueblos, tales como los monumentos de arquitectura, de arte o de historia, religiosos o seculares, los campos arqueológicos, los grupos de construcciones que por su conjunto ofrezcan un gran interés histórico o artístico, las obras de arte, manuscritos, libros y otros objetos de interés histórico, artístico o arqueológico, así como las colecciones científicas $y$ las colecciones importantes de libros, de archivos o de reproducciones de los bienes antes definidos.
\end{abstract}

b) Los edificios cuyo destino principal y efectivo sea conservar o exponer los bienes culturales muebles definidos en el apartado a), tales como los museos, las grandes bibliotecas, los depósitos de archivos, así como los refugios destinados a proteger en caso de conflicto armado los bienes culturales muebles definidos en el apartado a).

\footnotetext{
126 ABAD LICERAS, José María. "La protección nacional e internacional de los bienes culturales en caso de conflictos armados". En Noticias Jurídicas, octubre de 1998. http://noticias.juridicas.com/articulos/00-Generalidades/199810not20 2.html (consultado el 13 de octubre de 2010).
} 


c) Los centros que comprenda un número
considerable de bienes culturales definidos en los
apartados a) y b), que se denominarán "centros
monumentales"127.

\begin{abstract}
Con el paso del tiempo se han incorporado bienes intangibles como hechos, acontecimientos simbólicos, singulares y folclóricos de una sociedad (fiestas, tradiciones populares, itinerarios culturales, manifestaciones linguísticas...) quedando plasmadas en la Convención de la UNESCO (2003) del Patrimonio Inmaterial. En noviembre de 2010 el flamenco ha sido declarado, por la UNESCO, Patrimonio Inmaterial de la Humanidad.
\end{abstract}

De esta manera, el siglo XX sufrirá un cambio muy importante para la conservación del Patrimonio Cultural y que según Ana María Miguel ${ }^{128}$ se caracteriza por:

- Una mayor valoración de los Bienes Culturales
y ampliación del concepto de Patrimonio a
Artes Aplicadas (o Industriales), las
producciones artísticas o funcionales de las
colonias, las obras de arquitectura
monumental, rural y etnológico, conjuntos...
- Nuevos problemas técnicos y de criterio al
introducir nuevos materiales.
- Gran actividad normativa para la protección
del patrimonio cultural.

127 Convención para la Protección de los Bienes Culturales en caso de conflicto armado, firmado en La Haya el 14 de mayo de 1954. Artículo $1^{\circ}$.

128 Profesora Titular de la Facultad de Bellas Artes de la Universidad Complutense de Madrid. 
- Mayor sensibilidad y actividad jurídica internacional y nacional frente al expolio.

- Comienzo de la regulación de la profesión de conservador-restaurador y mejor formación del personal ${ }^{129}$.

A continuación se mostrará una serie de documentos y leyes, tanto nacionales como internacionales, desde principios del siglo XX hasta el día de hoy, que aglutinan los planteamientos teóricos y legislativos sobre el Patrimonio Cultural:

- 1900. En España se centralizan las competencias en materia de Patrimonio Histórico en la Dirección General de Bellas Artes.

- 1911. Ley de Excavaciones Arqueológicas. España.

- 1915. Ley de Conservación de Monumentos HistóricoArtísticos. España.

- 1926. Decreto Ley sobre el "Tesoro Artístico Nacional". España.

- 1931. Carta de Atenas de la Restauración y Conservación de los Monumentos de Arte e Historia -Patrimonio Arquitectónico- .

- 1932. Cartas del Restauro, Italia -restauración de monumentos-.

- 1933. Carta de Urbanismo de Atenas.

- Ley del 13 de Mayo del Tesoro Artístico, sobre la defensa, conservación y acrecentamiento del patrimonio histórico-artístico Nacional -normas para la restauración de libros y documentos-, España.

129 MACARRÓN MIGUEL, Ana Ma . Idem. p. 54. 
- 1949. Creación del Consejo de Europa.

- 1954. Convención de la Haya -Convención para la Protección de los Bienes Culturales en caso de Conflicto Armado-.

- Convenio Cultural Europeo, París.

- 1955. Ley de 22 de diciembre -usos inadecuados del valor y significado de los monumentos-. España.

- 1956. Recomendación de Nueva Delhi -define los principios internacionales que deberán aplicarse a las excavaciones arqueológicas-.

- 1958. Ley de 22 de julio -monumentos provinciales y locales-. España.

- 1964. Carta de Venecia -Carta Internacional sobre la conservación y la restauración de Monumentos y de Conjuntos Histórico-Artísticos-.

- Comisión Franceschini.

- 1963. Recomendación número 365 relativa a la defensa y valoración de los sitios -urbanos y rurales- y de los complejos Histórico - Artísticos.

- 1967. Carta de Quito -Cascos Históricos-.

- 1969. Convenio Europeo para la Protección del Patrimonio Arqueológico, Londres.

- 1970. Convención sobre tráfico ilícito de Bienes culturales.

- 1971. Recomendación 589.

- 1972. Carta del Restauro, Roma -técnicas de restauración de cada tipo de arte. Fue redactada por 
Cesare Brandi ${ }^{130}$ con la colaboración de Guglielmo De Angelis D'Ossat ${ }^{131}$.

- Convención sobre la Protección del Patrimonio Mundial Cultural y Natural (Carta de París).

- 1975. Carta Europea del Patrimonio Arquitectónico, Bruselas.

- Declaración de Ámsterdam -confirma los valores de la anterior carta, la Carta Europea del Patrimonio Arquitectónico-.

- 1976. Recomendación de Nairobi -Salvaguardia de los Conjuntos Históricos y su Función en la Vida Contemporánea- .

- Carta de Turismo Cultural, Bruselas -importancia del turismo, su fuerte crecimiento en el futuro y su incidencia en los monumentos-.

- Carta de México (defensa del Patrimonio Cultural).

- 1977. Normas de Quito -conservación del Patrimonio Arquitectónico- .

- 1978. Constitución Española.

- Recomendación sobre la protección de los bienes culturales muebles.

- 1979. Recomendación 880 de la Asamblea del Consejo de Europa -conservación del Patrimonio Arquitectónico-.

- 1980. Recomendación sobre la salvaguardia y la conservación de las imágenes en movimiento.

- Recomendación 881 de la Asamblea Parlamentaria relativa al Patrimonio Arquitectónico Rural.

130 Historiador y crítico de arte, ensayista y especialista en la teoría de restauración de obras de arte (1906-1988).

131 Director General del Patrimonio Cultural de Italia. 
- 1981. Carta de Florencia o Carta Internacional de los Jardines y Sitios Históricos.

- 1982. Conferencia de Berlín - se le da importancia al territorio que rodea al monumento-.

- 1984. El conservador-restaurador: una definición de la profesión, Copenhague -redactado por el Grupo de Trabajo del Comité Internacional para la Conservación con el título "Formación en conservación y restauración"- .

- 1985. Ley del Patrimonio Histórico Español.

- Convención para la salvaguardia del Patrimonio Arquitectónico de Europa (Carta de Granada).

- Convenio Europeo sobre las infracciones contra los Bienes Culturales (Convención de Delfos).

- 1986. Carta de Toledo o Carta Internacional para la Conservación de las Ciudades Históricas.

- Carta de Noto -recuperación de los centros históricos y su aplicación al territorio italiano- .

- 1987. Reglamento de Museos.

- Nueva Carta del Restauro de la Conservación y Restauración de los objetos de arte y cultura (para sustituir la anterior Carta del Restauro italiana de 1972, normas para la restauración de libros y documentos).

- Documento de Pavía -perfil europeo del conservador-restaurador-.

- 1990. Carta Internacional para la Gestión del Patrimonio Arqueológico.

- Ley de Regulación del Patrimonio Cultural Vasco.

- Ley de Regulación del Patrimonio Histórico de Castilla-La Mancha. 
- Normas reguladoras del Patrimonio Documental y Archivos de Canarias.

- 1991. Ley que regula el Patrimonio Histórico de Andalucía.

- Ley que regula los Archivos y el Patrimonio Documental de Castilla y León.

- 1992. Carta de Veracruz, México -centros históricos iberoamericanos-.

- Convenio Europeo sobre la protección del Patrimonio Arqueológico, La Valetta (Malta, Italia).

- 1993. Ley que Regula el Patrimonio Cultural Catalán.

- 1994. Documento de Nara, Japón -resultado de la Conferencia de Nara en autenticidad respecto a la Convención del Patrimonio mundial-.

- 1995. Convenio de Unidroit, Roma -restitución internacional de los bienes culturales robados o exportados ilegalmente-.

- Ley que Regula el Patrimonio Cultural de Galicia.

- Coloquio sobre la conservación y uso de los Teatros Clásicos (Declaración de Sagesta).

- 1996. Carta Internacional para la protección y gestión del Patrimonio Cultural Subacuático.

- Declaración de Kinshasa -comercio y tráfico ilegal-.

- 1997. Carta sobre el uso de los Lugares Clásicos de Espectáculo (Carta de Verona).

- 1998. Ley del Patrimonio Cultural Valenciano.

- Ley de Patrimonio Histórico de la Comunidad de Madrid.

- Ley del Patrimonio Histórico de las Islas Baleares. 
- Ley del Patrimonio Cultural de Cantabria.

- 1999. Carta de Burra, Australia (Sitios de Significación Cultural).

- Ley del Patrimonio Histórico y Cultural de Extremadura.

- Ley del Patrimonio Cultural de Aragón.

- Ley del Patrimonio Histórico de Canarias.

- Principios que deben regir la conservación de las estructuras históricas en madera, México. ( ICOMOS) .

- Carta del Patrimonio Vernáculo Construido.

- 2000. Carta de Cracovia -actualización de la Carta de Venecia-.

- Protección de los Bienes Culturares en caso de conflicto armado, Ginebra.

- Convenio Europeo para la Protección del Paisaje, Florencia.

- 2001. Normas reguladoras del Patrimonio Cultural del principado de Asturias.

- Convenio de Protección del Patrimonio Arqueológico Subacuático.

- 2002. Ley del Patrimonio Cultural de Castilla y León.

- Directrices profesionales de ECCO: la profesión y su código ético, Bruselas -Confederación Europea de Organizaciones de Conservadores-Restauradores, aprobado por su Asamblea General-.

- 2003. Carta de Nizhny Tagil, Moscú -Conservación del Patrimonio Industrial, TICCIH-.

- Convención para la salvaguardia del Patrimonio Cultural Inmaterial, París.

- Declaración de la UNESCO relativa a la destrucción intencional del Patrimonio Cultural, París (Resultado de la Conferencia General de la 


\begin{tabular}{lll}
\hline & Organización de las Naciones Unidas para la \\
& Educación, la Ciencia y la Cultura). & \\
$\circ$ & Principios para el análisis, conservación y \\
& restauración de las estructuras del Patrimonio \\
& Arquitectónico (ICOMos) . \\
$\circ$ & Carta sobre la preservación del Patrimonio \\
& Digital.
\end{tabular}

- 2004. Ley de Patrimonio Cultural, Histórico y Artístico de La Rioja.

- 2005. Carta de Ename -interpretación de lugares pertenecientes al Patrimonio Cultural-.

- Ley Foral del Patrimonio Cultural de Navarra.

- Convención sobre la Protección y Promoción de la Diversidad de las expresiones Culturales.

- 2006. Código de Deontología del ICOM para los Museos.

- 2007. Ley del Patrimonio Histórico Andaluz.

- Normas reguladoras del Patrimonio Cultural de la Comunidad Autónoma de la Región de Murcia.

- 2008. Terminología del ICOM para definir la conservación del patrimonio cultural tangible, Nueva Delhi.

Por tanto, es muy importante conocer nuestro legado cultural para transmitirlo a generaciones venideras, conservarlo, protegerlo y difundirlo, además de investigarlo y fomentarlo, para que no desaparezca y sea conocido por la humanidad. 


\subsection{LA CONSERVACIÓN PREVENTIVA EN EL MUSEO}

Debemos conocer el pasado, comprender el presente $y$ evitar la destrucción en el futuro.

Luisa Isabel Álvarez de Toledo y Maura ${ }^{132}$

Una vez introducidos en el origen de la conservación del Patrimonio nos detendremos en la evolución y desarrollo que ha tenido la conservación y la restauración en el ámbito museístico.

A lo largo de los años se han empleado multitud de términos para referirse a la conservación, entre ellos encontramos: conservación preventiva, preservación, conservación curativa, restauración patrimonial, conservación activa, conservación pasiva, entre otros.

Para concretarlas, se podrían clasificar dos tipos de actuaciones: acciones directas e indirectas. Las primeras englobarían las técnicas curativas o de restauración realizadas directamente sobre la pieza modificando parte de su materia constitutiva. Las segundas, las acciones de conservación preventiva, se realizarían modificando el entorno del objeto sin necesidad de intervenir directamente en la obra.

132 Escritora e historiadora española, fue jefa de la Casa de Medina Sidonia (1936-2008). 
Ambas acciones deben tener como fin alargar lo máximo posible la vida física del objeto.

El código ético del ICOM hace referencia al respecto de este modo:

El museo debe supervisar con atención el
estado de las colecciones para determinar cuándo un
objeto o espécimen puede exigir un trabajo de
conservación o restauración y los servicios de un
especialista cualificado. El principal objetivo debe
ser la estabilización del objeto o espécimen. Todos
los procedimientos de conservación deben estar
documentados y ser reversibles en la medida de lo
posible, de la misma manera que toda modificación
del objeto o espécimen originales se debe poder
identificar claramente ${ }^{133}$.

Por tanto, explicaremos cada tarea por separado (su definición, características, historia y su actividad dentro del museol aunque en ambos casos estemos hablando de conservación.

Al ser dos conceptos tan relacionados, a lo largo del tiempo han sido confundidos y se han llegado a identificar el uno con el otro, por lo que sería necesario diferenciarlos.

Se comenzará explicando la actividad de la restauración ya que la conservación preventiva ha sido heredada de los saberes de ésta, además de otras ramas de la ciencia.

\footnotetext{
133 Código de deontología del ICOM para los Museos. Título 2, artículo 2.24. 2006.
} 


\section{RESTAURACIÓN}

\section{- Definición y características}

La restauración es una intervención directa y puntual que se realiza sobre el objeto con el fin de detener y acabar con un proceso de deterioro activo y recuperar, por tanto, el estado original en el que se encontraba la obra, su función estética o valor histórico.

Es una operación técnica que intenta recomponer y reparar la estructura material -y la legibilidad de la imagen- de la obra, su consolidación, por lo que conlleva un elevado conocimiento de las técnicas y materiales constitutivos de la misma ${ }^{134}$. Todo ello sin borrar huellas del paso del tiempo a través de la obra, ni pretender falsificar el estilo de la obra ni su valor como documento histórico.

Éste es el trabajo con el que tradicionalmente se ha identificado a los conservadores-restauradores, sin embargo en la actualidad las nuevas necesidades museológicas potencian las actuaciones de conservación e investigación ${ }^{135}$.

134 AA. VV. "Técnicas científicas aplicadas al conocimiento de los Bienes Culturales". En Curso de Iniciación a la Conservación del Patrimonio, Centro de enseñanza virtual Liceus. Madrid. Universidad de Alcalá, 2007.

135 Conservación y restauración. Museo Guggenheim de Bilbao. http://www.museobilbao.com/conservacion-restauracion.php (consultado el 1 de agosto de 2010). 
Cesare Brandi, en la obra Teoría del Restauro (1963), afirma que la restauración es la intervención encaminada a devolver al objeto su eficiencia, es decir, su unidad potencial, su integridad absoluta -denominada Restauración crítica o filológica-.

Constituye el momento metodológico del reconocimiento de la obra de arte en su consistencia física y en su doble polaridad histórica y estética, con vistas a su transmisión al futuro ${ }^{136}$.

Para él, al contener la obra de arte un mensaje que puede ser entendido por sus espectadores, exige que toda intervención que se realice en ella se dirija a devolverle la unidad potencial a la imagen. Esto quiere decir que ha sido interrumpida su lectura estética, por lo que es necesario actuar sobre la obra conservando al mismo tiempo su aspecto histórico y testimonios de las épocas vividas.

\section{- Historia}

Casi siempre ha existido la preocupación por la forma de conservar, ordenar y mantener los objetos.

En Roma, la restauración era sinónimo de reparación o reconstrucción, idea que se continuará durante la Edad Media. Más tarde, en el Renacimiento, es cuando se comienza a apreciar cierta sensibilidad hacia las prácticas de restauración, más concretamente en Italia. Los encargados de estas tareas eran los artesanos, más tarde serán los artistas.

136 BRANDI, Cesare. Teoría de la Restauración. Madrid, 1989. p. 15. 
En un principio estas labores consistían en tratamientos para su mantenimiento e indicaciones a los artistas sobre los materiales que debían emplear primando la calidad y pensando en una mayor durabilidad ${ }^{137}$.

A partir del siglo XVI es habitual encontrar intervenciones, tanto en esculturas como en pinturas, en las que pintores famosos añadían capas de pintura a las obras (repintes o veladuras) o reconstruían partes de la obra.

Ya en el Barroco -siglo XVII- se expande la idea de restaurar con el objetivo de "arreglar" las galerías privadas ${ }^{138}$. Además, se discute y polemiza sobre los principios y doctrinas del arte, iniciándose en materia de restauración la crítica de las técnicas y los criterios a adoptar, centrándose en los problemas que presenta la restauración de pinturas, tales como el re-entelado, la limpieza y las pátinas ${ }^{139}$.

En España destacará una figura importante, Francisco Pacheco, un tratadista del arte que escribe en 1649, Arte de la Pintura, su antigüedad y su grandeza.

\footnotetext{
137 SEDANO ESPÍN, Pilar. "Montaje y gestión de Departamentos de conservación y restauración". En Actas de los XVI cursos monográficos sobre Patrimonio Histórico (Reinosa, Julio 2005). p. 245.

138 CALVO MANUEL, Ana María. "Tendencias actuales en conservaciónrestauración de pintura". En Actas de los XVI Cursos Monográficos sobre el Patrimonio Histórico. Reinosa, Julio de 2005. p. 164. 139 AA. VV. Idem.
} 
En el siglo XVIII, con la Ilustración, comenzará a distinguirse el restaurador del artista. Aparecerán las primeras escuelas de restauradores y con ello el comienzo de adaptación de los conocimientos adquiridos hasta entonces sobre causas de deterioro y comportamiento de materiales. ${ }^{140}$.

En este momento la ciencia está al servicio del arte, por tanto se realizarán los primeros exámenes científicos y análisis físico-químicos a los materiales constitutivos de la obra. Del mismo modo se comienza a establecer una metodología sobre los tratamientos de intervención.

El objetivo de estos iniciales estudios científicos era informar al artista y proporcionar una base "científica" al arte, dentro de ese espíritu ilustrado que buscaba potenciar la ciencia y la técnica ${ }^{141}$.

Pero este concepto no comienza a desarrollarse más ampliamente hasta el siglo XIX, donde esta tarea empieza a ser cada vez más profesional. Las labores de mantenimiento, reconstrucción y restauración de las obras del pasado son más frecuentes, al igual que los estudios sobre análisis científicos.

Vicente Poleró y Toledo142 escribió en el año 1855 El Arte de restaurar. Observaciones relativas a las

\footnotetext{
140 BRUQUETAS GALÁN, Rocío. "La conservación preventiva: una nueva profesión con una vieja historia". En Curso sobre Exposiciones temporales y conservación del Patrimonio. Grupo Español del IIC. Facultad de Geografía e Historia de, Universidad Complutense de Madrid. Madrid, 5 al 8 de Abril, 2005. p. 3.

141 Ibídem.

142 Pintor gaditano, escritor y restaurador del Museo del Prado y del Monasterio del Escorial (Madrid).
} 
restauraciones de cuadros, el primer documento sobre la restauración en español.

Pero será a comienzos del siglo XX cuando se debatirá Y cuestionarán las restauraciones e intervenciones realizadas hasta el momento, quedando de este modo plasmadas en revistas especializadas. Asimismo, a raíz de lo expuesto anteriormente, se crearán multitud de laboratorios e institutos que comienzan a experimentar con los estudios realizados hasta el momento. Entre los primeros destacan el laboratorio del Museo Británico (Londres, 1919) y el laboratorio de restauración del Museo del Louvre (París, 1931).

Pocos años después, en 1934, aparece el Instituto Max Doerner en Munich y en 1938 se crea el Instituto Centrale per il Restauro (Roma). En el año 1945 se fundarán el IIC (Instituto Internacional para la Conservación de Obras Históricas y Artísticas), el IRPA (Institute Royal du Patrimoine Artistique ${ }^{143}$ ) en Bruselas y el Instituto José de Figueiredo en Lisboa ${ }^{144}$. Un centro de gran importancia a nivel internacional es el ICCROM (Centro Internacional para el Estudio de la Preservación y la Restauración del Patrimonio Cultural), creado en 1958.

En España nacerá en 1961 el Instituto de Conservación y Restauración de Obras de Arte (I.C.R.O.A), que pasó a denominarse en 1985 el Instituto de Conservación y Restauración de Bienes Culturales (ICRBC) que más tarde, en 1996, se llamó Instituto del Patrimonio Histórico Español (IPHE) .

\footnotetext{
143 Real Instituto de Patrimonio Artístico. 144 AA. VV. Idem.
} 


\section{- La restauración como actividad en el museo}

En muchas ocasiones -por diferentes motivos y causaslos bienes que albergan los museos necesitan ser restaurados. Esta restauración dependerá del tipo de material con que esté realizada la obra y su técnica de ejecución, es decir, si son bienes muebles e inmuebles (pintura de caballete, pintura mural, esculturas en madera, piezas cerámicas y arqueológicas, fotografía, litografía, mobiliario...).

Es un trabajo de taller y laboratorio que complementa con las investigaciones históricas de las diferentes piezas.

A continuación se expondrán algunos criterios de restauración para respetar al máximo posible los bienes, en este caso nos centraremos en los bienes culturales muebles, ya que son los que hallaremos en un museo:

- Acciones de prevención del deterioro.

- Mínima intervención.

- Investigación y análisis interdisciplinar.

- Estudio exhaustivo -informe-.

- Documentación (escrita, fotográfica y gráfica).

- No falsificación.

- Respeto por el original.

- Protección jurídico-administrativa. 


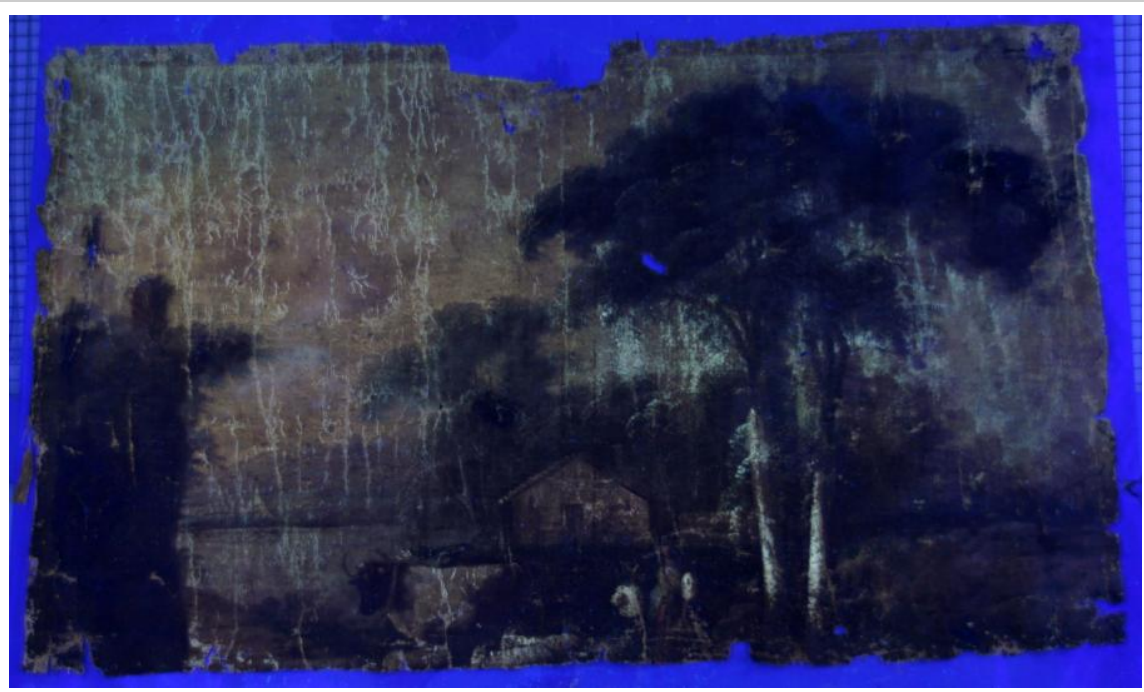

Figura 7. Documentación de una pintura sobre lienzo con luz ultravioleta

Foto de la autora

Algunas operaciones comunes de restauración destacan:

- El examen de diagnóstico. Estudio de la técnica de ejecución, el soporte, la naturaleza del material, las causas de alteración y sus posibles consecuencias... Para conocer el estado de conservación de la pieza y así escoger el tratamiento de restauración más adecuado.

- Elaboración del informe del estado de conservación.

- Empapelado o protección de la capa pictórica.

- Tratamientos sobre el soporte:

- Eliminación de parches y añadidos antiguos. 

- Desinfección ${ }^{145}$ y desacidificación ${ }^{146}$.
- Eliminación y corrección de deformaciones.
- Colocación de injertos y parches.
- Reentelado o forración ${ }^{147}$-en el caso de restauración de pintura sobre lienzo-.

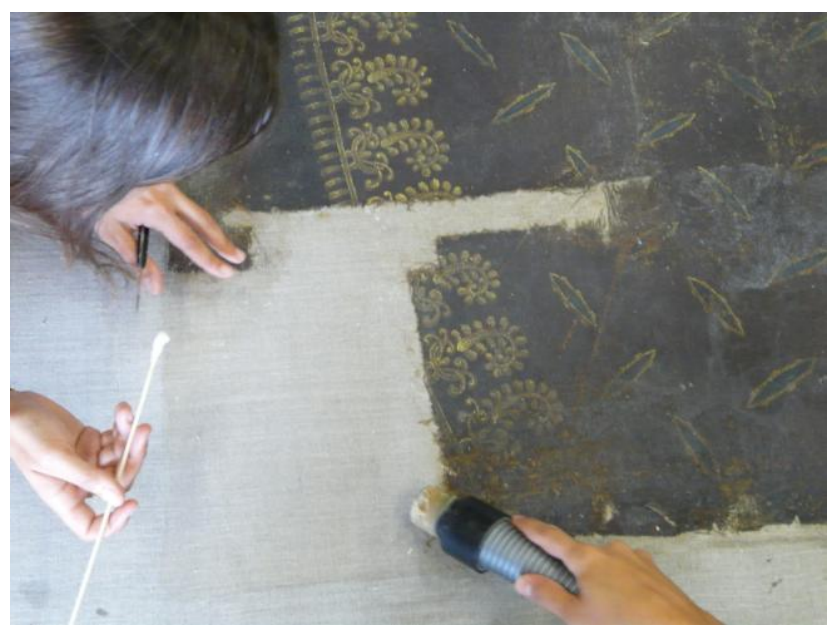

Figura 8. Tratamiento sobre el soporte. Preparación para la colocación de un injerto en una pintura sobre tela Foto de la autora

- Tratamientos en la capa pictórica.

- Fijación y consolidación.

- Regeneración y sentado del color.

- Estucado, nivelación del estucado y desestucado.

\footnotetext{
145 Proceso realizado a través de medios físicos, mecánicos o químicos con el objetivo de neutralizar o matar los agentes o gérmenes patógenos.

146 Proceso en el cual se elimina o neutraliza la acidez del material.

147 Colocación de una tela nueva cuando la original se encuentra muy degradada y ha perdido su función, por medio de un engrudo de harina aplicado en caliente -forración a la gacha-.
} 


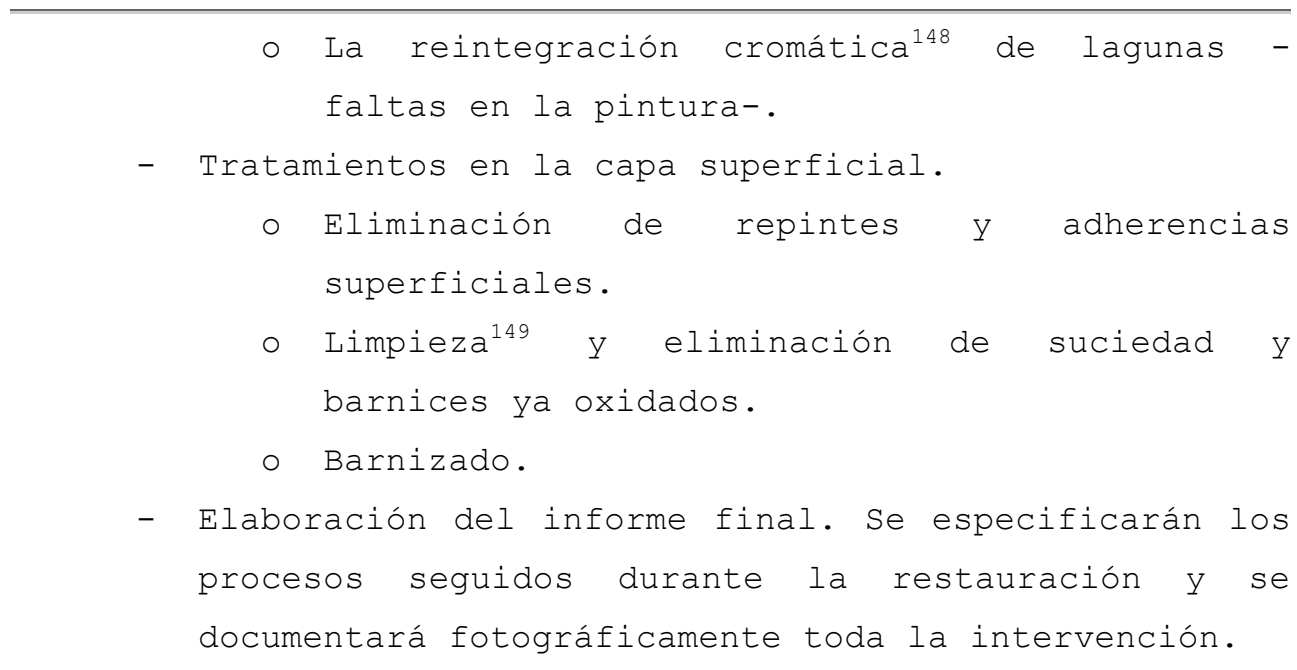

Normalmente estas acciones se realizan en el laboratorio o taller del propio museo -si dispone de ellos-, pero en el caso de que la institución no estuviera suficientemente acondicionada para realizar tales intervenciones, las obras se trasladarían a otros laboratorios o talleres -ya sean dependientes del museo o pertenecientes a empresas privadas de restauración- y una vez intervenidas regresarían nuevamente a su destino.

Estos laboratorios cumplen un papel fundamental a la hora de conocer científicamente las obras. Muchos museos elaboran boletines o revistas de publicaciones periódicas donde dan a conocer, tanto a la comunidad científica como al público en general, toda la información referente a la obra.

\footnotetext{
148 Se puede realizar con diferentes técnicas: puntillismo, tratteggio o rigattino -técnica de rayado-, abstracción, selección cromática, tinta neutra, veladuras...

149 Existen varios grados de limpieza: superficial, media, moderada o total.
} 
En el caso de los museos españoles de titularidad estatal se cuenta con la Ley del 25 de junio de 1985 del Patrimonio Histórico Español para realizar las distintas intervenciones en los bienes ${ }^{150}$. Veamos algún ejemplo:

En el caso de los bienes inmuebles, las
actuaciones irán encaminadas a su conservación,
consolidación y rehabilitación y evitarán los
intentos de reconstrucción, salvo cuando se utilicen
partes originales de los mismos y pueda probarse su
autenticidad. Si se añadiesen materiales o partes
indispensables para su estabilidad o mantenimiento,
las adiciones deberán ser reconocibles y evitar las
confusiones miméticas ${ }^{151}$.

Las restauraciones respetarán las aportaciones de todas las épocas existentes. La eliminación de alguna de ellas sólo se autorizará con carácter excepcional y siempre que los elementos que traten de suprimirse supongan una evidente degradación del bien y su eliminación fuere necesaria para permitir una mejor interpretación histórica del mismo. Las partes suprimidas quedarán debidamente documentadas ${ }^{152}$.

Otras cartas y documentos internacionales a seguir en cuanto a criterios de conservación son la Carta de Atenas

\footnotetext{
150 "Restauración en los Museos". Ministerio de Cultura. http://www.mcu.es/museos/CE/Funciones/Conservacion/Restauracion.html (consultado el 28 de julio de 2010). 151 Artículo 39.2, Título IV. 152 Ibídem.
} 
(1931), la Carta de Venecia de 1964, la Carta del Restauro de 1972, Nueva Carta del Restauro de 1987, el Documento de Pavía de 1987, y la Carta de Cracovia (2000). Todas ellas insisten en las ideas de respeto histórico y artístico y recuperación de la legibilidad del bien cultural, pero salvaguardando todos sus valores materiales y documentales intactos, sin eliminar aportaciones de otras épocas, ya que son testimonio del quehacer humano153.

\section{CONSERVACIÓN PREVENTIVA}

\section{- Definición y características}

La conservación es el tratamiento que recibe un objeto para eliminar todo proceso de degradación que pueda deteriorar la obra y protegerlo ante posibles alteraciones. Se incluyen las tareas de mantenimiento y prevención, examen de la pieza y documentación e investigación la obra a $\operatorname{tratar}^{154}$.

La diferencia que existe entre conservación y restauración es que la primera rechaza cualquier añadido que complete la unidad de la pieza, por lo que aceptaría el estado fragmentado de la obra.

Según Paloma Muñoz-Campos ${ }^{155}$, una de las definiciones más completas que podemos encontrar al respecto es la de

\footnotetext{
153 "Restauración en los Museos". Idem.

154 MARTIARENA, Xabier. "Conservación y Restauración". En Cuadernos

de Sección. Artes Plásticas y Documentales. N 10, 1992. p. 209.

155 Restauradora y Conservadora, Jefe del Departamento Museo Nacional de Artes Decorativas, Madrid.
} 
Marie Berducou -Directora del IFROA ${ }^{156}$-. Ésta afirma que la conservación preventiva promueve una estrategia productiva para organizar y asegurar la accesibilidad de las colecciones en las diferentes funciones del museo, con el fin de preservar el mayor tiempo posible su integridad física. A esta definición le podemos añadir unas palabras de Baba Beitia (Director de la Escuela de Patrimonio Africano),...al menor coste posible, pero con la máxima eficacia ${ }^{157}$.

Por tanto, se entiende por conservación preventiva el conjunto de actividades cuyo objetivo es el conocimiento de las causas de deterioro de las obras de arte y el empleo de técnicas y herramientas de control de dichas causas ${ }^{158}$. Por 10 que es aplicable a todo el Patrimonio.

Es un proceso que empieza antes de la intervención directa sobre el objeto -la restauración- y debe continuarse después de ésta, ya que la pieza debe de estar custodiada en unas condiciones apropiadas que eviten que el deterioro se active nuevamente. Es, según Gaël de Guichen, aumentar la esperanza de vida de los objetos. Por lo que su finalidad es proteger los Bienes Culturales de todo tipo de agresiones, ya sean por factores naturales o humanos.

El 8 de octubre 2004 los miembros del ICOM aceptaron por primera vez dentro del código ético el término de Conservación Preventiva, definiéndolo como un elemento

\footnotetext{
156 Instituto de Formación para la Restauración de Obras de Arte. 157 Citado por Benoit Tapol en Curso de Conservación Preventiva de Tejidos e Indumentaria. Museo Nacional de Antropología, Madrid, 2000 .

158 BRUQUETAS GALÁN, Rocío. Idem. p. 1.
} 
importante de la política de los museos y de la protección de las colecciones ${ }^{159}$.

Un concepto que se ha ampliado considerablemente y ha sido aceptado, pero sus límites están todavía por definir... ${ }^{160}$

\section{- Historia}

Como vimos en anteriores capítulos, y según afirmaba Pilar Sedano, desde los comienzos de la historia de la humanidad con las primeras expresiones artísticas, encontramos la preocupación por conservar los objetos y obras de $\operatorname{arte}^{161}$.

El alemán Friedrich Wilhelm Rathgen, en 1888, fue el primer director de los Laboratorios de Química del Museo Real de Berlín. Persona que ayudó considerablemente al nacimiento de la conservación gracias a su publicación Manual de Conservación en 1898.

Se puede decir que en el siglo XIX fue el Museo del Prado quien prestó más atención a la práctica de la conservación preventiva, aunque ya en el siglo XVIII, en los primeros museos importantes, aparecen actuaciones de almacenaje, acondicionamiento, transporte, iluminación,...

Una de las consecuencias indirectas de la Revolución Francesa fue la creación en 1793 del Museo del Louvre, un ejemplo a seguir para todos las instituciones ya que tenía

159 GÓMEZ, Marisa, DE TAPOL, Benoit. Idem. p. 42.

160 Ibídem.

161 SEDANO ESPÍN, Pilar. Idem. p. 245. 
como objetivo recoger y exponer las obras incautadas. Hubert Robert, primer conservador del Louvre, personaliza las nuevas inquietudes que se estaban produciendo dentro de los museos, al tratar de equipar la iluminación cenital de la galería de esta institución mediante la instalación de cristaleras en la bóveda.

Este tipo de iluminación se convertirá, a partir de este momento, en la favorita del resto de los museos y galerías de arte al permitir una iluminación uniforme y constante, además de evitar el sol directo sobre las obras, tan dañino para su conservación y para su correcta visión ${ }^{162}$.

Gaël de Guichen destaca cuatro fases importantes en el "camino" seguido por la Conservación Preventiva, o mejor dicho, en la evolución de su significado y su campo de aplicación ${ }^{163}$.

Una primera etapa, entre 1957 y 1977, en la que aún no se denominaba Conservación Preventiva y las actuaciones se limitaban solamente al control del clima.

En el periodo de 1975 a 1990 aparecen nuevas actividades que van a denominarse con el término "Prevención", por lo que la unión de estas dos palabras conservación y prevención- aparece en los textos a partir de

\footnotetext{
162 BRUQUETAS GALÁN, Rocío. Idem. p. 4.

163 GÓmez, Marisa, DE TAPOL, Benoit. "Medio siglo de Conservación Preventiva. Entrevista a Gaël de Guichen". En Ge-conservación, $\mathrm{N}^{\circ} 0$, 2009. p. 36 .
} 
1975, cuando el ICCROM crea el curso Prevención en los Museos ${ }^{164}$.

Se publicarán varias normativas y escritos pero todavía la conservación preventiva sigue entendiéndose como una actividad que controla los factores ambientales y lumínicos, relacionándose igualmente con la seguridad frente al vandalismo y robo. A partir de este momento se amplía el concepto de conservación preventiva al incluir, como objeto de estudio, los tipos de soportes de las obras, el tipo de embalaje utilizado, el transporte y el almacenamiento de obras. Igualmente se elaboran Planes de Emergencia en caso de siniestros y la prevención se introduce en ámbitos tales como los archivos o las bibliotecas ${ }^{165}$.

Pero los conservadores-restauradores no tienen conciencia de la importancia de la Conservación Preventiva hasta que Denis Guillemard ${ }^{166}$ organizó en 1992 la I Conferencia Internacional sobre Conservación Preventiva ${ }^{167}$, en la que se reunió en un único tomo todos los estudios dedicados a los principales agresores del Patrimonio ${ }^{168}$.

164 Dirigido tanto a conservadores de museos, conservadoresrestauradores, como a arquitectos y administradores.

165 MUÑOZ CAMPOS-GARCÍA, Paloma. "Conservación preventiva de colecciones textiles: el primer paso". En Curso El textil y la indumentaria, Grupo Español del ICC en colaboración con el Instituto del Patrimonio Histórico Español (IPHE) y la Universidad Complutense de Madrid (UCM). Madrid, 31 de Marzo al 3 de Abril, 2003. p. 2. 166 Profesor de Conservación y Restauración de la Universidad de París, participó en el programa PREMA (Prevención en Museos en África) .

167 Realizada en París con la ayuda de la UNESCO, del 8 al 10 de Octubre de 1992 .

168 GÓmEZ, Marisa, DE TAPOL, Benoit. Idem. p. 40. 
Una fecha a destacar es 1996, momento en el que el Comité de Conservación del Consejo Internacional de Museos (ICOM-CC) crea un grupo de trabajo de Conservación Preventiva con entidad propia ${ }^{169}$. Este Comité será el promotor de los más importantes congresos internacionales de conservación de Bienes Culturales, en donde se darán a conocer los últimos avances en esta profesión ${ }^{170}$.

En el siglo XX, entre las obras que estudian la conservación-restauración destaca el libro de Harold James Plenderleith ${ }^{171}$, Conservación de Antigüedades y Obras de Arte: tratamiento, reparación y restauración, considerado, según Gaël, como La Biblia de muchos conservadores-restauradores de obras.

La última etapa que plantea Gaël de Guichen -entre los años 2000 y 2007- corresponde al momento de reconocimiento científico de la disciplina.

\section{- La conservación como actividad en el museo}

Pasemos a ver la actividad de la conservación preventiva en relación a las funciones del museo.

Como es sabido, la prevención -esencial dentro del museo y para cualquier bien patrimonial-es la primera acción que debemos realizar en una colección museográfica para evitar la restauración, ya que antes de actuar directamente

\footnotetext{
169 MUÑOZ CAMPOS-GARCíA, Paloma. Idem. p. 2.

170 BRUQUETAS GALÁN, ROcío. Idem. p. 17.

171 Químico, conservador y arqueólogo escocés.
} 
sobre la pieza es mejor controlar los agentes y causas que provocan su deterioro para alargar al máximo posible la vida del objeto.

Una buena conservación preventiva evita actuaciones de restauración, que siempre se deben contemplar como intervenciones límite cuando no existen otras alternativas ${ }^{172}$. Una acción que envuelve las normas y leyes jurídicas de protección del Patrimonio Histórico hasta las tareas de inventario y catalogación ${ }^{173}$.

Algunos de los objetivos principales de la conservación preventiva son:

- Poner orden e identificar las colecciones ubicadas en zonas de almacén.

- Definir los riesgos actuales a los que está sometida la pieza y los potenciales.

- Tomar las medidas necesarias con las piezas que tengan peligro de pérdida.

- Controlar las condiciones ambientales (humedad, temperatura y luz) en todas las áreas del museo y realizar inspecciones periódicas.

- Revisar la limpieza de todas las obras.

- Elaboración de normas para una correcta manipulación, transporte, almacenaje y exposición, así como su supervisión.

- Supervisión de las condiciones de préstamos de obras a otros museos e instituciones.

172 "Restauración en los Museos". Ministerio de Cultura. Idem.

173 BRUQUETAS GALÁN, Rocío. Idem. 
- Elaboración del Plan de Protección de Colecciones ante Emergencias.

Es muy importante que toda persona relacionada con esta área de conocimiento conozca y sepa qué es la conservación preventiva y cual puede ser la técnica o el método más adecuado a la hora de erradicar y prevenir el deterioro de la obra. Y, que según el código deontológico del ICOM, a los profesionales de museos les incumbe la responsabilidad fundamental de crear y mantener un entorno adecuado para la protección de las colecciones, almacenadas, expuestas o en tránsito ${ }^{174}$.

Este deterioro es un proceso que podemos controlar pero no evitar, por lo que uno de los grandes retos de los expertos en conservación consiste en conseguir un equilibrio entre el disfrute del Patrimonio y su cuidado.

Además, todo personal que trabaje en y para el museo, (mantenimiento, seguridad, arquitectos, ingenieros, el personal de cada departamento...) tendrá que tener un básico conocimiento de estas medidas de protección, incorporar hábitos de trabajo preventivos y evitar despistes que puedan dañar, deteriorar e incluso hacer desaparecer alguna pieza de la institución ${ }^{175}$. Como el hecho ocurrido hace algunos años en

174 Código deontológico del ICOM para los museos, 2006. Apartado 2. Protección de las colecciones. Artículo 2.23, Conservación preventiva.

175 En 1977, Garry Thomson -investigador químico de la National Gallery, Londres- publica El Clima en el Museo. Libro que no solamente se dirige a los conservadores-restauradores, sino también al personal que trabaja en el edificio del museo, los arquitectos y los ingenieros. 
la Tate Britain de Londres, cuando un trabajador perteneciente al área de limpieza tiró una bolsa de basura que se encontraba en una sala sin saber que ésta era una obra de arte ${ }^{176}$. Desafortunadamente, la pieza no se pudo recuperar y fue reemplazada por una nueva. Otro caso similar sucedió con una intervención del artista británico Damien Hirst, cuando una empleada de la limpieza tiró un cenicero lleno de colillas, botellas y paquetes de tabaco vacíos que conformaban parte de la obra ${ }^{177}$. Son acciones que debemos evitar a toda costa.

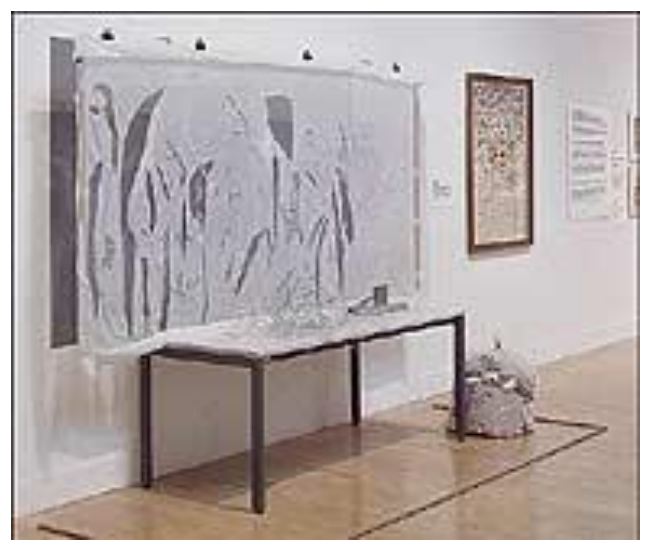

Figura 9. La composición de Gustav Metzger en la Tate. (BBC)

Pero esta actividad no es única del personal de cada institución museística, sino que todos los ciudadanos debemos velar por mantener nuestro legado histórico, artístico y cultural, ya sean bienes materiales -tangibles- o inmateriales -intangibles-. Para que este propósito pueda llegar a su fin es necesario que el visitante o espectador

\footnotetext{
176 Periódico El Mundo. Domingo, 29 de agosto de 2004. http://www.elmundo.es/elmundo/2004/08/27/cultura/1093603576.html (Consultado el 26 de julio de 2010). 177 Ibídem.
} 
sea consciente del valor y la fragilidad de estos bienes únicos e insustituibles, de los cuidados que se necesitan y que no es una tarea única de los conservadores de los museos. Es un trabajo en equipo.

Al respecto, hay que decir que el ICCROM (Centro Internacional de Estudios para la Conservación y la Restauración de Bienes Culturales) establece una nueva función en 1994 en sus estatutos. Ésta es la de impulsar todas las iniciativas orientadas a crear en el público una mejor comprensión de la conservación y de la restauración de los bienes culturales ${ }^{178}$.

Dentro de estos bienes culturales debemos mencionar los bienes inmateriales ya que al transmitirse oralmente de generación en generación tienen un gran riesgo de pérdida, por lo que hay que vigilar y conservar para que no desaparezcan con el paso de los años. Esto se puede llevar a cabo gracias a las tecnologías que disponemos en la actualidad que permiten grabar esta información por vía audiovisual y de esta manera asegurar su existencia con el paso del tiempo.

En la conservación de la colección del museo es indispensable mantener una atmósfera climática relativamente estable sin oscilaciones bruscas de humedad y temperatura, ya que pueden provocar la aparición de microorganismos, así como fenómenos de contracción, corrosión y dilatación de los

178 Estatutos del Centro Internacional de Estudios para la Conservación y la Restauración de Bienes culturales (ICCROM). Artículo 1 . 
diferentes materiales que harán que se acelere el proceso de deterioro de las obras ${ }^{179}$.

Para ello habrá que tener en cuenta los diferentes materiales -tanto orgánicos como inorgánicos- y los tipos de obras de que está formada la colección de la institución (escultóricas, arqueológicas, arquitectónicas, artesanales, mobiliario, obras documentales, fotografías, dibujos, grabados, litografías...). Al estar realizadas con diferentes tipos de materiales (papel, madera, óleo, barro, metal, piedra...) cada tipo de obra requerirá unas condiciones climáticas diferentes, lo que dificultará establecer unas condiciones de conservación comunes a todas ellas.

Podemos afirmar que los parámetros más delicados son el control de la temperatura y de la humedad. Estas deben ser constantes, sin grandes oscilaciones, manteniendo la humedad del entorno de la pieza rondando el 56\% y una temperatura de unos $17^{\circ}$ C. Pero como veremos, estos datos variarán dependiendo de cada caso, obra y situación.

La humedad es la que quizás puede deteriorar y perjudicar más la colección del museo, ya que las obras pueden sufrir deformaciones ${ }^{180}$ tanto si el ambiente es demasiado seco como demasiado húmedo, provocando en este caso la aparición de moho, bacterias y hongos. Uno de los deterioro más frecuentes que sufren las obras pictóricas.

$179 \quad$ AA. VV. Normativas técnicas para Museos. http://museosdevenezuela.org (consultado el 26 de julio de 2010). 180 Deshidratación de los materiales constitutivos de la obra, aparición de grietas y/o fisuras, desprendimientos, craquelados, pérdida de elasticidad en el material... 
La temperatura, aunque es un factor importante, ya que grandes fluctuaciones pueden provocar deterioros en la obra tanto químicos, físicos como biológicos-, es un agente de deterioro secundario porque ésta puede variar en cada museo dependiendo de las características de su colección, del propio museo, e incluso de su localización.

Otras causas de deterioro son los microorganismos (biodeterioro ${ }^{181}$ ), la mala y continua manipulación de las piezas, las vibraciones, golpes y accidentes que se producen en su transporte, la luz (rayos infrarrojos y ultravioletas), la atmósfera y el propio aire del museo, la composición de los materiales expositivos, las malas instalaciones y diseño del propio edificio... Sin olvidarnos de los factores naturales (terremotos, inundaciones, huracanes, incendios...) y humanos como robos, vandalismo, guerras, atentados y agresiones. Como fue el caso de asalto en 1972 que sufrió la obra escultórica La Piedad de Miguel Ángel, en el que parte de esta pieza fue destruida a martillazos por un visitante.

Algunos instrumentos que ayudan a prevenir este tipo de daños son: alarmas antiincendios, termómetros, higrómetros ${ }^{182}$, termohigrómetros ${ }^{183}$, termohigrógrafos ${ }^{184}$, psicómetros ${ }^{185}$, mangueras y extintores de incendios,

\footnotetext{
181 Transformaciones indeseadas en un material producidas por la actividad vital de organismos y microorganismos.

182 Miden la humedad relativa.

183 Aparato que mide la temperatura y humedad relativa del aire. 184 Equipo que registra tanto la temperatura como la humedad relativa. Está compuesto de un termógrafo y un higrógrafo. 185 Aparato formado por dos termómetros que calcula el grado de humedad del aire.
} 


\begin{tabular}{|c|c|c|c|}
\hline sensores & movimientos, & data & loggers ${ }^{186}$ \\
\hline deshumidificadores ${ }^{187}$, & sistemas & de & seguridad \\
\hline
\end{tabular}

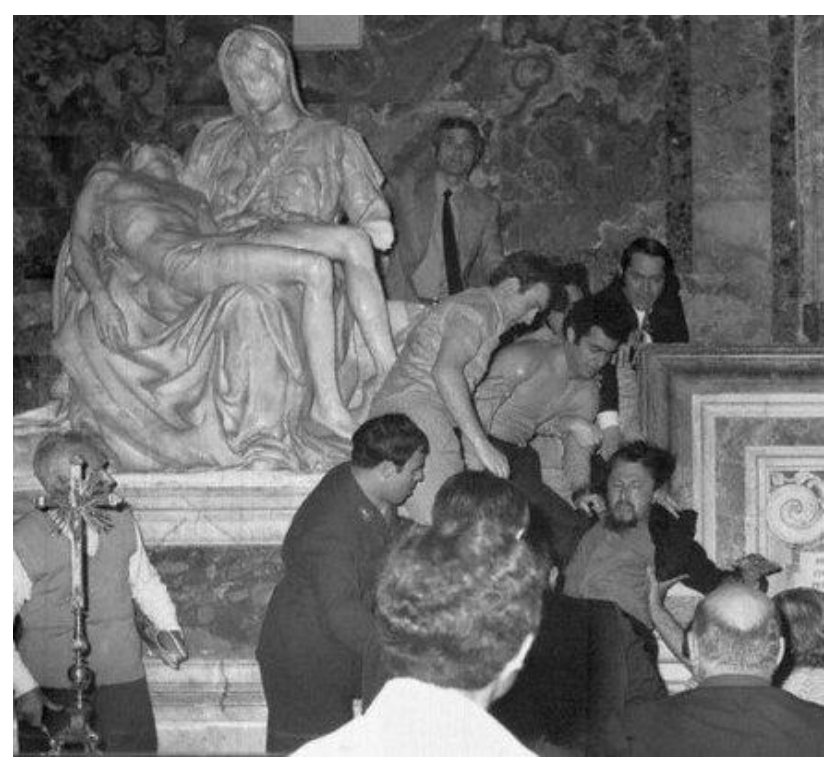

Figura 9. Momento posterior de la agresión de Lazlo Toht a la obra escultórica. Se puede apreciar el deterioro sufrido en el rostro y el brazo

En relación con las obras de arte contemporáneo nos encontramos en un campo poco conocido pues se trata de creaciones, en muchos casos, frágiles, realizadas con nuevos materiales y que por tanto se desconoce su durabilidad. Son piezas a las que nos enfrentamos sin saber todavía los cambios que se producirán en ellas con el paso de los años.

\footnotetext{
186 Dispositivo electrónico que reúne valores de medición de diferentes sensores. Controlan todo tipo de datos ambientales. 187 Aparato que reduce la humedad del ambiente.
} 


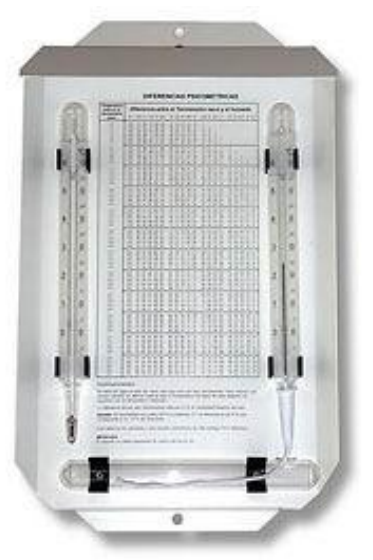

Figura 10. Psicómetro

Además de todas estas acciones de conservación y prevención se debe guardar toda la documentación referida a cada pieza de la colección, entre ellas el análisis de su estado de conservación, para de esta manera facilitar las futuras intervenciones que se realicen en ellas.

En conclusión, la conservación preventiva debe ser planificada, diseñada y redactada previamente por el personal de la institución ya que es necesaria en todos los museos.

Aunque hoy en día existe gran protección en los museos, desafortunadamente todavía se siguen cometiendo destrozos y accidentes en nuestro Patrimonio, pero eso sí, con menos frecuencia que en años anteriores. Por lo que una correcta seguridad en el museo debe ser otro factor a tener en cuenta en la conservación de las piezas del mismo, tema sobre el que nos centraremos más adelante.

Por tanto, es muy importante concienciar y educar a la población para conservar y proteger nuestro Patrimonio del presente para ser disfrutado por las siguientes generaciones. 


\subsection{LA CONSERVACIÓN DE MOVIMIENTOS DE OBRAS,}

\section{ALMACENES Y ESPACIOS EXPOSITIVOS.}

Las condiciones de conservación de los fondos de un museo variarán dependiendo de los distintos espacios del mismo. No se darán las mismas circunstancias en las salas expositivas, donde hay más afluencia de público y se exhiben los fondos de la institución, que en los almacenes y zonas de depósito de obras.

De poco sirve -o nada- centrarse en mantener y
controlar las piezas aisladamente si no se plantea la
conservación de las colecciones de una manera global.

En general, en el museo se distinguen cuatro espacios diferenciados por su uso. Estos son: la zona pública sin colecciones, la zona pública con colecciones, las zonas no públicas con colecciones y, por último, las zonas no públicas sin colecciones ${ }^{188}$.

En este caso nos centraremos en las zonas donde se albergan piezas, ya sean para ser exhibidas -espacios expositivos- o para ser atesoradas -almacenes y depósitos de objetos-. Las técnicas de conservación preventiva son más cautelosas en estos espacios que acabamos de mencionar.

\footnotetext{
188 MUÑOZ CAMPOS-GARCíA, Paloma. "La conservación en el museo. Conservación preventiva y criterios para la restauración". En Curso de Iniciación a la Museología, Centro de enseñanza virtual Liceus. Madrid. Universidad de Alcalá, 2007.
} 
Pero no sólo es importante la zona de almacenaje o exhibición de las piezas, sino que es necesario igualmente controlar las áreas de tránsito de las obras, donde se manipula o trasladan a cualquier otra parte del edificio.

En la zona pública con colecciones, es decir, las salas de exposición, es donde hay que prestar más cuidado y atención, ya que son espacios donde conviven el público y las piezas, por lo tanto hay que tener controles más precisos de conservación. Pero igualmente existen controles ambientales en las áreas no públicas con bienes, como son los laboratorios, almacenes o los talleres de conservaciónrestauración. De este modo, se requiere de unas condiciones específicas para mantener las obras.

En todas estas áreas es importante trabajar en equipo y en coordinación, lo que implica una constante comunicación entre todos los implicados para prever posibles riesgos.

Benoit de Tapol comenta al respecto,

El responsable se tiene que enfrentar a un
conjunto de operaciones que tienen que permitir
asegurar la integridad física de los objetos,
organizar los fondos, salvaguardar los datos
permitiendo su conocimiento y reflexionar sobre sus
estatutos. La complejidad del proyecto conlleva una
organización rigurosa y estrictamente planificada,




\footnotetext{
así como la necesidad de recurrir a otros

profesionales externos al museo ${ }^{189}$.

Veamos qué requisitos de conservación se requiere en cada uno de estos espacios.
}

\title{
ALMACENES
}

\begin{abstract}
Un almacén es un lugar físico donde se depositan géneros, en este caso son los Bienes Culturales que no se encuentran en exhibición. Además, en este mismo lugar es donde se inician y terminan las labores de ingreso en el museo y salida a la exposición, por lo que le debe aportar una gran seguridad a estas piezas.
\end{abstract}

Paloma Muñoz lo define así:

Un almacén de objetos artísticos no debe ser una buhardilla o un trastero en el que acumulamos lo que no tiene cabida en la exposición de la colección permanente. El almacén de un museo, lugar de residencia habitual de muchos de nuestros objetos, es un espacio vivo y dinámico, que debe ser accesible a distintos "usuarios", por lo que exige ser gestionado con eficacia. En él entran nuevas adquisiciones $y$ de él salen las obras con destino a exposiciones temporales. Recibe a menudo la visita

189 DE TAPOL, Benoit. "El diálogo entre el conservador y el arquitecto sobre las exigencias climáticas de las colecciones y la aplicación de consignas". En Museos.es, $\mathrm{N}^{\circ} 1,2005$. p. 68. 
de investigadores e incluso, de vez en cuando, de autoridades ${ }^{190}$.

En muchas ocasiones las instituciones museísticas han prestado poca atención a estos lugares de depósito. Son espacios donde las obras pasan gran parte del tiempo, por 10 que es imprescindible unas condiciones específicas para el mantenimiento de las mismas, revisar y vigilar su estado, además de las características y diseño del espacio, ya que es fundamental para un uso correcto.

José Ángel Palomares explica que los almacenes son un conjunto de unidades inmuebles que reúnen: en primer lugar, los tradicionales locales donde se almacenan las obras; en segundo lugar, las zonas de recepción de los fondos museísticos, con muelles de carga y descarga, y los locales anexos de embalaje y desembalaje; en tercer lugar, las salas destinadas a los investigadores para la consulta de las obras, si éstas se incluyen dentro del complejo de almacén, que es lo que más recomendable; y en cuarto, y último lugar, las dependencias anexas de mantenimiento, como son: taller de carpintería, locales de acondicionamiento climático de las piezas recibidas... Todo ello según las necesidades y el tamaño del museo ${ }^{191}$.

Uno de los mayores problemas con los que se encuentran numerosos museos -por no decir todos- es la falta de espacio y por consiguiente, el problema de almacenamiento de las obras.

\footnotetext{
190 MUÑOZ-CAMPOS GARCíA, Paloma. Idem. p. 125.

191 PALOMARES SAMPER, José Ángel. "Almacenes en los museos". En Revista de Museología, Año IV, N 13, Febrero de 1998. p. 131.
} 
El hecho de tener insuficiente espacio para almacenar las piezas o exponerlas, ha provocado que gran cantidad de estas instituciones se vean en la necesidad de reformar sus instalaciones, ya sea para ampliar salas, modificar las ya existentes, o trasladarse de sede.

Otras, al no poder contar con suficientes recursos económicos para este tipo de actuaciones, reúnen todas las piezas -tanto en la sala de exposición como en el almacéndando un aspecto al museo un tanto abigarrado y aglomerado haciendo aún más complicada la lectura para el visitante.

Como afirma María Marco, el problema del almacenamiento en las galerías de los Museos ha perdurado hasta bien entrado el siglo XX. Las imágenes de las salas del prado con pinturas que cubrían todo el muro hasta el techo, no son muy lejanas en el tiempo ${ }^{192}$.

Así mismo, comenta que el almacén debería ocupar el 40\% de un museo, destinado el otro 40\% para las salas de exposiciones y el $20 \%$ restante a oficinas, hall, talleres, salas de conferencias, cafetería, tienda... ${ }^{193}$

Como se ha dicho, el espacio tiene que estar muy bien diseñado para que cumpla correctamente con la función de almacenaje. Con la experiencia y el paso de los años se ha comprobado que un mal diseño y organización en los almacenes ha provocado grandes daños en la colección del museo.

192 MARCO SUCH, María. Estudio y análisis de los museos y colecciones museográficas de la provincia de Alicante. Alicante. Universidad, 1998. p. 413. (tesis doctoral. 193 Ibídem. p. 431. 
Al no tener un flujo permanente de personas -salvo para el mantenimiento, inspecciones o visitas programadas- las condiciones climáticas no dependerá del bienestar humano sino de la propia política del museo.

Veamos, por tanto, los aspectos importantes que hay que tener en cuenta:

- La ubicación. Evitar situarlos en áticos o sótanos, zonas con exceso de humedad o temperatura, como las calderas.

- La comunicación con los diferentes espacios del museo. Debe situarse en conexión directa con el muelle de carga y descarga, la sala donde permanecerán las obras de cuarentena, los laboratorios de conservación-restauración, el plató de fotografía y la sala de exhibición.

- El tamaño y amplitud del espacio. Hay que pensar en los equipos que se utilizarán (montacargas, carritos...) y considerar que la colección del museo se ampliará con el paso de los años.

- El acceso al almacén -que sea fácil además de seguro- y a las diferentes piezas para que puedan ser localizadas rápidamente y que no las ponga en peligro.

- La organización de las obras. Se deberá respetar y mantener para evitar posibles pérdidas, y agrupar según las colecciones que albergue el museo (esculturas, pinturas, fotografías, piezas arqueológicas, textiles, grabados, mobiliario...).

- Las condiciones climáticas y lumínicas. Tiene que evitarse por completo la luz natural, por el contrario, la luz artificial dispondrá de filtros 


que prevengan las radiaciones ultravioletas e
infrarrojas. Igualmente deberá estar dotado de luces
de emergencia -teniendo en cuenta los niveles de
luxes ${ }^{194}$ necesarios-.
- Las piezas que estén infectadas o muy deterioradas,
ya que podría contagiar al resto de la colección.
- Los materiales utilizados en la elaboración del
mobiliario y los sistemas de embalaje -dependiendo
del tipo de obras-. Deberán ser "compatibles" con
los materiales constitutivos de las obras"ig5.
La extracción de gases que puedan contaminar la
atmósfera.
La tipología de muebles para el depósito de cada
tipo de obra (planeros, peines, armarios,
estanterías, muebles compactos...).

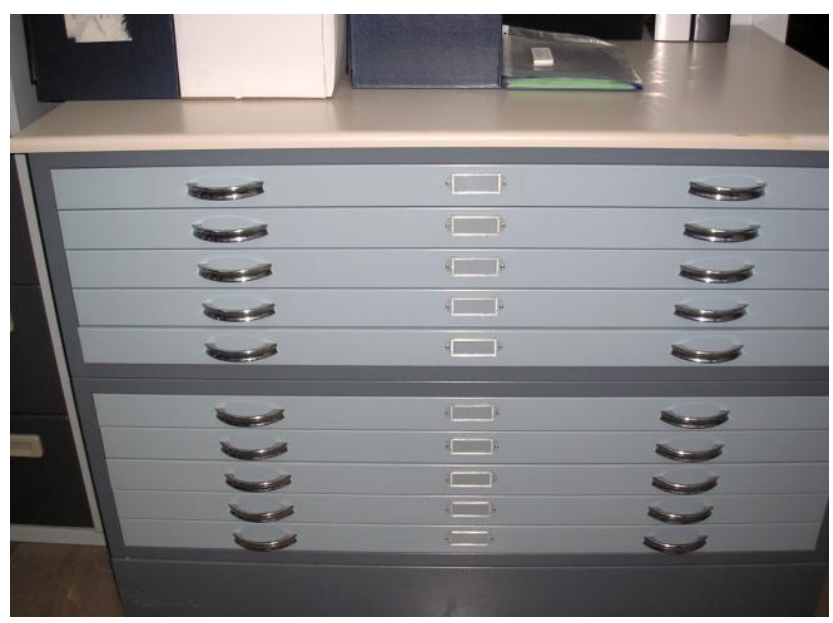

Figura 11. Planero para obras gráficas. Perteneciente al Museo de Bellas Artes de Granada

Foto de la autora

194 Un lux (lx) es la unidad derivada del Sistema Internacional de Unidades para la iluminancia o el nivel de iluminación. Basada en el lumen y a su vez en la candela. 195 MUÑOZ-CAMPOS GARCÍA, Paloma. Idem. p. 129. 
- La seguridad y vigilancia -controlar el acceso a personas no autorizadas-.

- La limpieza, la manipulación -lo debe realizar un personal cualificado para ello- y el mantenimiento de las obras.

Por todas estas razones, este espacio debe ser considerado como parte fundamental de la institución y no debe restársele importancia por la función vital que desempeña ${ }^{196}$.

\section{ESPACIOS EXPOSITIVOS}

Los espacios expositivos del museo son los lugares, como su nombre indica, donde se exponen al público los fondos de la institución, así como las obras pertenecientes a otros museos.

Por tanto, la sala de exposiciones debe realizar un servicio a la sociedad, un lugar donde se le informe, enseñe, comunique y deleite a través de los elementos que en ella se exhiban. Además de ayudar y colaborar con otras instituciones museísticas para el beneficio de toda la comunidad.

Es un lugar muy importante dentro del museo porque, ¿qué sería de él si no se exhibieran sus fondos?.

\footnotetext{
196 AA. VV. Conservación de colecciones de Arte e Historia y Arqueología. Manual básico de Conservación preventiva. Museo Nacional de Colombia. Bogotá, septiembre de 2002.p. 9.
} 
Según Luis Caballero la exposición es un sistema complejo formado por sistemas menores interrelacionados, que se condicionan unos a otros ${ }^{197}$. Es decir, encontramos en ellas diferentes sistemas que se relacionan entre sí:

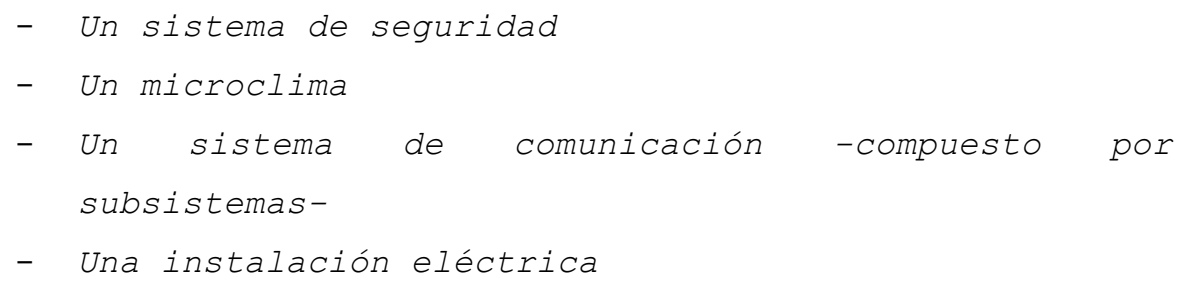

Los miembros que conforman cada grupo son expertos en uno de estos sistemas o en partes del mismo. Por lo que es conveniente que colaboren conjuntamente para que los objetivos de cada uno de estos programas resulten compatibles entre sii ${ }^{198}$.

Las exposiciones hay que diseñarlas y estudiarlas muy detenidamente, observando y analizando las ventajas e inconvenientes que pudiera tener a la hora de exponer una colección.

Al igual que con las salas de almacenamiento y depósito, hay que tener en cuenta que este lugar debe ser espacioso, flexible, que no ocasione problemas a otras áreas del museo y de fácil acceso para el público y las obras. Además deben estar cerca de la zona de almacén y sala de vigilancia -si la hubiere-.

197 CABALLERO GARCÍA, Luis. "Exposiciones temporales: definición, gestión y organización". En Curso de Iniciación a la Museología, Centro de enseñanza virtual Liceus. Madrid. Universidad de Alcalá, 2007 .

198 Ibídem. 


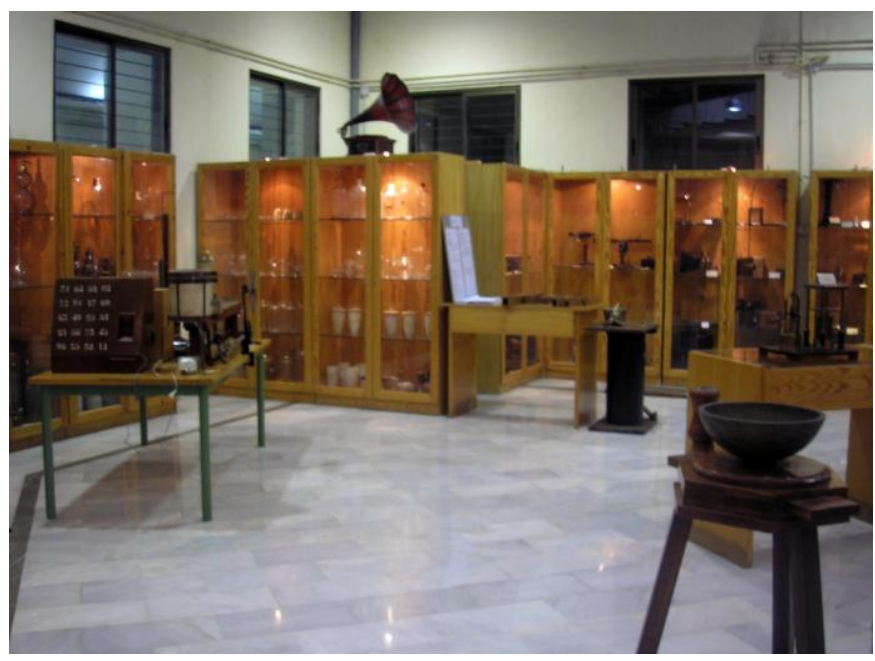

Figura 12. Sala de exposición del Museo de las Ciencias Naturales del Instituto Padre Suárez, Granada Foto de la autora

De la misma manera, hay que prestar atención a otros aspectos -tanto para las exposiciones temporales como las permanentes-, como: la selección de los objetos, el montaje del mobiliario y la distribución de las obras, los sistemas audiovisuales, multimedia y proyectivos, las texturas y colores de los espacios, la ubicación de los textos informativos (y su legibilidad), el diseño y colocación de los soportes expositivos, las señales de orientación del recorrido, el diseño del mismo recorrido, el personal de vigilancia, los controles de humedad y temperatura y la iluminación.

El código deontológico del ICOM se refiere al respecto con las siguientes palabras:

Las exposiciones temporales, ya sean materiales o virtuales, deben ser conformes a las 
misiones, políticas y finalidades declaradas del museo. No deben ir en detrimento de la calidad ni la protección y conservación de las colecciones ${ }^{199}$.

Para conservar correctamente las obras de la sala hay que comprobar que todo el mobiliario que se utilice (peanas, paneles, muros, moquetas,...) estén realizados con materiales adecuados -resistentes e inertes- y que por tanto no emitan gases contaminantes que perjudiquen las obras con el paso de los años.

En cuanto a las condiciones climáticas y lumínicas de la sala, será necesario impedir las visitas masificadas y las aglomeraciones de público para no causar cambios bruscos de temperatura y humedad de la atmósfera de la estancia.

Muchos soportes de las piezas requieren iluminación y climatización independiente y que sean regulables para cada obra. Al igual que el interior de las vitrinas estén acondicionadas con sistemas de seguridad y controles de la temperatura, humedad y luz, para evitar que se produzcan reacciones de condensación o de cualquier otro tipo.

Con respecto a la iluminación que deberá tener la sala en general, la luz natural es la más peligrosa por la emisión de radiaciones ultravioletas e infrarrojas, por lo que este tipo de alumbrado se debe evitar a toda costa.

Una exposición prolongada de los objetos a las radiaciones luminosas -ya sea natural o artificial- provoca

199 Código de deontología del ICOM para los Museos, 2006. Título 4, artículo 4. 1 . 
grandes daños en ellos $-y$ a veces irreversibles-, como fotooxidación, craqueladuras, decoloraciones -cambio cromático-, desintegración de estructuras... Aparte de esto, se aumenta considerablemente la temperatura de las piezas ocasionando graves efectos térmicos, y por consiguiente, deteriorando aún más la obra.

Un claro ejemplo es el caso del papel, un material celulósico realmente frágil en el que se producen graves deterioros tanto físicos como químicos.

Así pues, la composición química del material, las características de la luz y el tiempo de exposición a la misma, el contacto con el oxígeno y el dióxido de carbono, además del vapor de agua, son los causantes de la degradación de estos materiales.

A continuación se expondrán los rangos de iluminación recomendados para cada tipo de material ${ }^{200}$ :

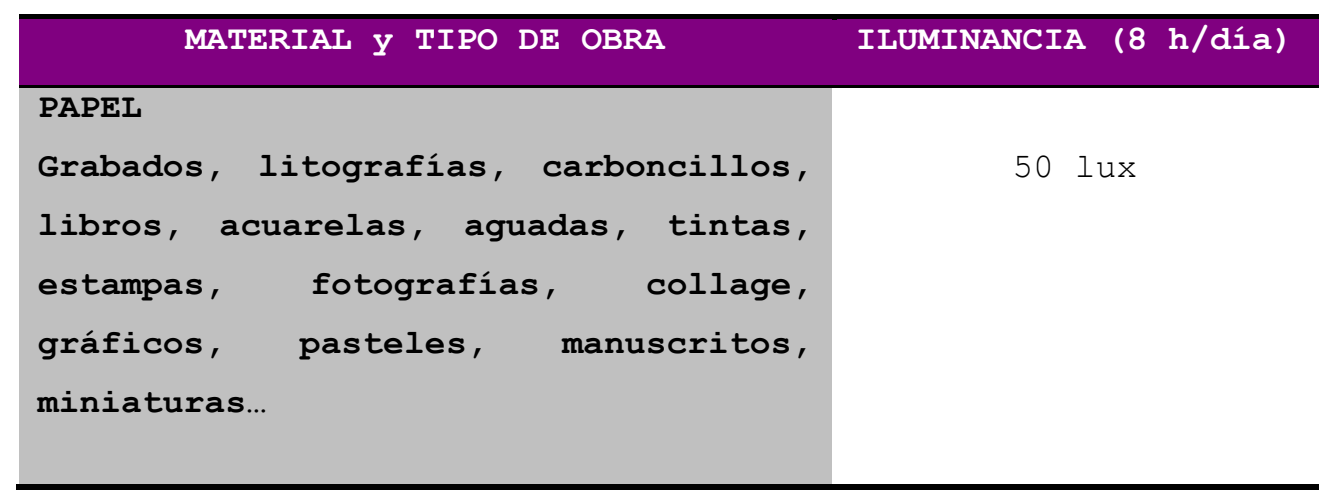

\footnotetext{
200 Ordenados de material más débil y sensible a la luz al más resistente.
} 


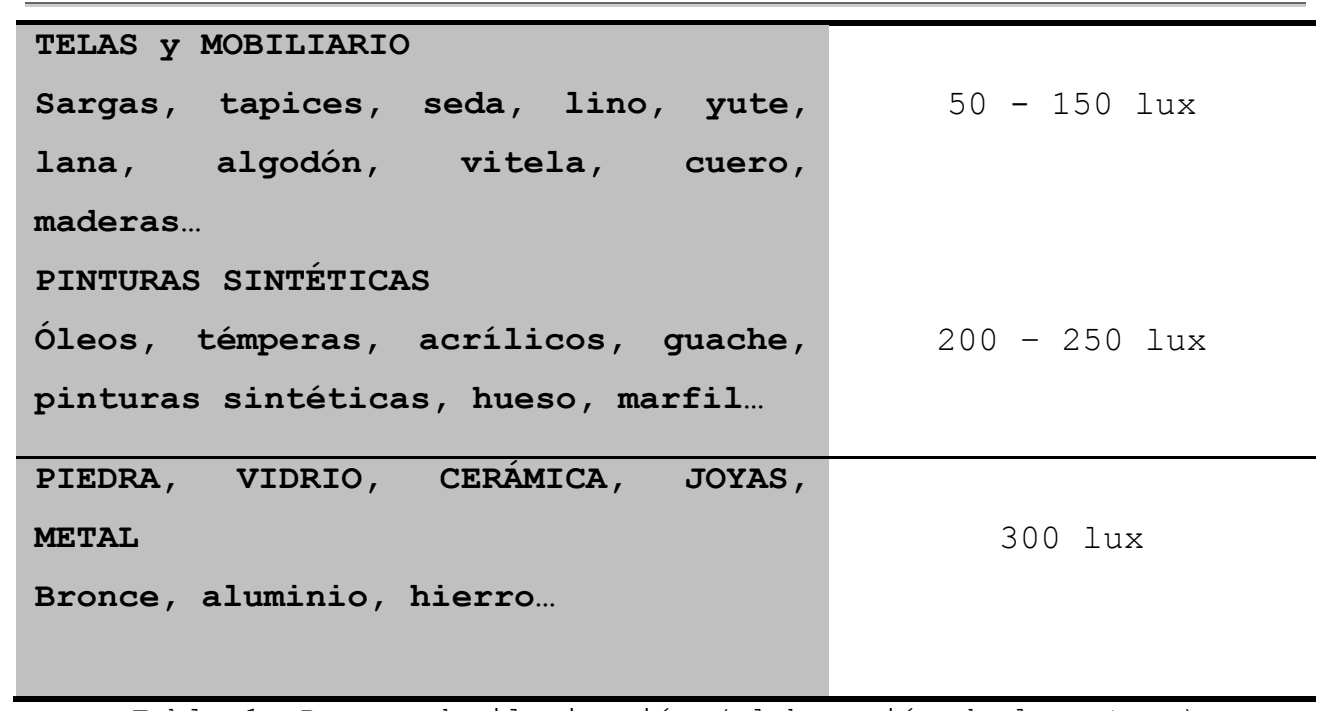

Tabla 1. Rangos de iluminación (elaboración de la autora)

Siempre que se vaya a realizar una exposición temporal prestando los fondos del museo a otras instituciones, se deberá tener especial cuidado en que las obras estén en buenas condiciones de conservación para ser trasladadas a otro lugar y no contagiar al resto de las piezas del museo. Igualmente, se tendrán que examinar las obras que provengan de otra institución para ser expuestas en el propio museo. Para ello, es necesario el informe del estado de conservación de los objetos donde se especifica si es necesario realizar actuaciones de restauración -si presenta deterioros- antes de ser trasladada, el tipo de embalaje adecuado, así como las condiciones ambientales que deberán mantener las obras durante el transcurso de la exposición ${ }^{201}$.

Para cerciorarse de que estos requisitos se cumplan correctamente, el museo que realiza la exposición tendrá que

201 SEDANO ESPÍN, Pilar. "La Conservación de las Obras de Arte en los Museos. Funciones del Departamento de Restauración". En ARBOR, Tomo CLXIV, $\mathrm{N}^{\circ}$ 645, Septiembre de 1999. p. 20. 
enviar regularmente los gráficos obtenidos de los aparatos de medición de las condiciones climáticas y lumínicas. Así como informar a la institución de cualquier accidente e imprevisto que pueda surgir durante la exhibición o su manipulación.

Concluida la exposición y antes del embalaje de las obras para ser transportadas al museo de origen, el correo 202 examina nuevamente la pieza y verifica el estado de conservación.

\section{MOVIMIENTOS DE OBRAS}

Desde que se tiene la noción de que existe un Patrimonio que debemos cuidar, proteger y legar a nuevas generaciones, se ha intentado mejorar las condiciones para que estos bienes patrimoniales padezcan el menor daño posible en su manipulación y traslado.

Ya en el siglo XVIII se comienzan una serie de acciones para frenar los deterioros que la Revolución Francesa inflingía sobre los Bienes Culturales. La gran cantidad de incautaciones que se cometieron en este periodo llevarán a la necesidad de acondicionar locales para almacenar las obras de arte y asimismo, poner medios para su transporte y embalaje. Una figura que estudió el modo de disponer estos locales fue el Conde de Angivillier ${ }^{203}$, que además se centró en la disposición de las luces y las medidas contra incendios. Otro

202 Es el que se encarga de supervisar que todo se encuentre correctamente antes, durante y después del viaje. Es una figura importantísima que vigila para la seguridad de las piezas. 203 Director General de las obras del Palacio Real de Luis XVI, Francia. 
artista que elaborará un informe con la descripción de las normas que debían seguirse para proteger las obras de arte será Sargent de Chartres ${ }^{204}$.

Un movimiento de obras muy destacado y que hay que comentar -y no olvidar- es el que se produce en 1797 tras la invasión de Napoleón a Italia. Bonaparte se adueña de una gran cantidad de obras de arte de diversa naturaleza y características para llevárselas a su país y aumentar de esta manera los fondos de sus museos. Los responsables que se encargaron de realizar el traslado de estas piezas dejaron por escrito las grandes dificultades e inconvenientes que tuvieron que vencer al viajar por las rutas con un convoy de doce carros tirados por bueyes. Estos carros se acondicionaron para amortiguar los movimientos con sistemas de suspensión en las ruedas y con tablado y rulos de esteras en el interior. Las obras más voluminosas se enviaron por mar con las precauciones debidas para evitar la humedad en las cajas. Los lienzos grandes se enrollaron en cilindros separados con hojas de papel y sujeto con bandas para impedir movimientos, sin embargo, los de tamaño medio y los entelados, se embalaron individualmente en cajas acondicionadas, alquitranadas y cubiertas de tela encerada. Se envolvían con paja y se colocaban sobre rodillos de esteras de juncos para defenderlas de las sacudidas. Por último, las estatuas se transportaron en cajas más sólidas y

204 BRUQUETAS GALÁN, Rocío. "La conservación preventiva: una nueva profesión con una vieja historia". En Curso sobre Exposiciones temporales y conservación del Patrimonio. Grupo Español del IIC. Facultad de Geografía e Historia de, Universidad Complutense de Madrid. Madrid, 5 al 8 de Abril, 2005. p. 4. 
sujetas para impedir los movimientos bruscos que se pudieran producir durante el trayecto ${ }^{205}$.

El movimiento y transporte de las obras es una actividad fundamental dentro y fuera de la institución museística. El hecho de manipular correctamente una pieza hace que se eviten deterioros innecesarios.

La colección del museo, ya sean obras pertenecientes a una colección permanente o temporal, puede trasladarse según dos movimientos: internos o externos. Los primeros son desplazamientos que se producen dentro de la institución y que pueden tener carácter temporal o permanente. En cambio, los movimientos que se producen fuera del museo pueden deberse a entradas de nuevas piezas, salidas de obras, préstamos, donaciones, depósitos o adquisiciones, pasando a formar parte de la zona de reservas 0 de los fondos permanentes. El Departamento de Registro del museo será quien controle y organice la entrada o salida de las piezas.

Como hemos visto, durante la manipulación, el transporte y el embalaje de las obras pueden aparecer muchos peligros. Por este motivo es necesario evaluar y prevenir los posibles riesgos que pudiera haber durante todo el trayecto antes de comenzar a transportar una pieza. La seguridad a la hora de manejar las obras y la limpieza, evitando las precipitaciones y movimientos bruscos a la hora de desplazarse, son otros factores a tener en cuenta. Además, es imprescindible tener toda la documentación necesaria en regla, como los permisos de movilidad, los préstamos de las obras, la planificación del viaje...

205 Ibídem. 
De la misma manera, es importante examinar la pieza detenidamente antes de ser manipulada, ya que cada una tendrá unas características diferentes. Estas acciones deben realizarlas personas especializas usando para ello medidas preventivas para no deteriorar las obras, un ejemplo es el uso de guantes de algodón durante su manipulación.

Veamos qué requisitos requiere cada tipo de pieza, ya sea una escultura o una pintura.

\section{- Pintura:}

- No mover más de una pintura al mismo tiempo.

- Las pinturas de tamaño grande deberán ser movidas por dos personas.

- Sujetar por debajo y el lateral de las obras.

- No apilar las obras unas encimas de otras, separarlas mediante cartones.

- Moverlas sin mantener contacto por la zona de la capa pictórica.

- Apoyar las pinturas en el suelo sobre algún soporte almohadillado y en posición vertical.

- Si sufre algún desprendimiento de pintura durante su manipulación, guardar el material desprendido para volver a recomponer, o en caso de que no pudiera ser posible, para su análisis.

- Usar guantes de algodón.

- Escultura:

- Observar y estudiar la pieza buscando las zonas más frágiles.

- No mover más de una escultura al mismo tiempo. 
- Las esculturas de tamaño grande deberán ser movidas por dos personas o más, si es necesario.

- Manipularlas con las dos manos evitando las zonas más delicadas y sobresalientes.

- Usar guantes de algodón o antideslizantes de seguridad para zonas más resbaladizas.

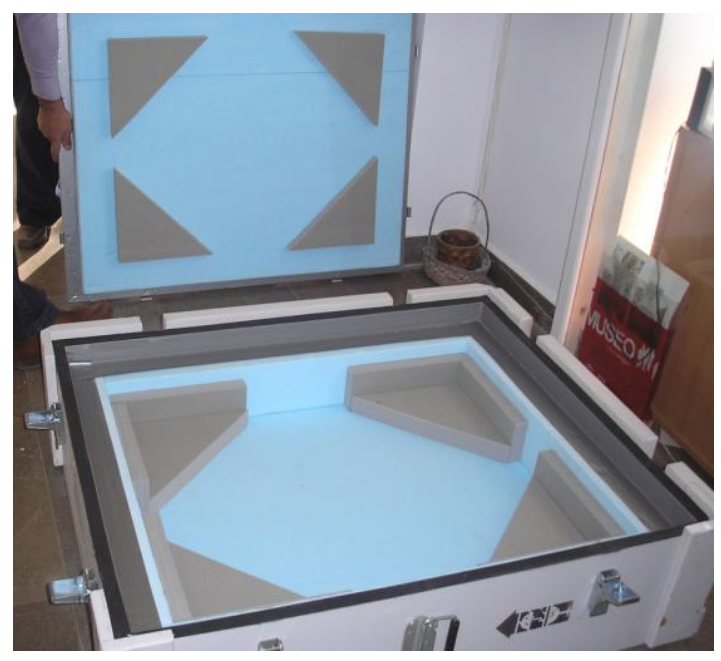

Figura 13. Interior de una caja para transportar obras.

Perteneciente al Museo de Bellas Artes de Granada Foto de la autora

El embalaje, recipiente que sirve para transportar objetos, debe resistir los movimientos y posibles golpes que pueda sufrir durante el traslado, al igual que proteger y conservar los objetos que alberga en su interior. Debe ser sólido y seguro, hermético, aislante, poseer amortiguadores internos que eviten las vibraciones y con controladores de humedad y temperatura. Los materiales que se utilizan pueden ser flexibles o rígidos, dependiendo de la finalidad y el tipo de obra. Los más utilizados son la madera, el metal o el plástico, pero indistintamente deben ser materiales que no se 
deformen -resistentes-, que no intoxiquen a las obras neutros-, y no abrasivos, entre otros factores.

Para pequeñas obras y piezas valiosas suelen guardarse en maletines de mano que las transporta el correo.

En el caso de objetos que por sus características físicas (peso, tamaño, forma...) requieran embalajes especiales, éstos se diseñarán a medida adaptándose a sus necesidades.

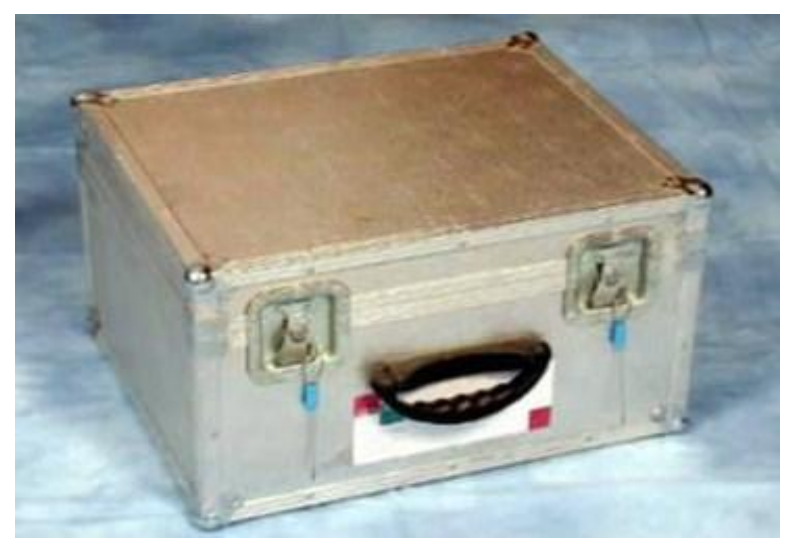

Figura 14. Maletín de mano para transportar obras de pequeño tamaño

Los materiales que se utilicen para envolver los objetos igualmente deberán elegirse dependiendo de su acidez, durabilidad, resistencia, rugosidad o composición química.

No se debe olvidar la colocación de señales de seguridad en el exterior de los paquetes donde se informe de su fragilidad, el sentido en el que debe colocarse y de los factores que debe evitar, como la humedad, exceso de iluminación, el uso de ganchos para su manipulación... 


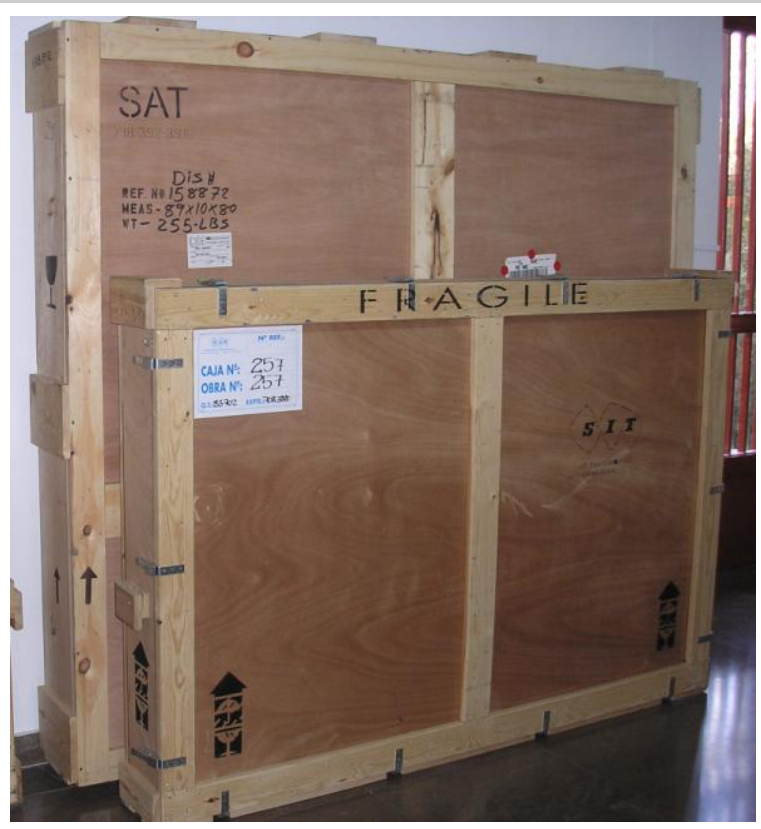

Figura 15. Embalaje de una obra informando sobre su manipulación. Perteneciente al Museo de Bellas Artes de Granada Foto de la autora

Simultáneamente a los trabajos de embalaje y protección se debe realizar un registro de la información, ya que uno de los grandes problemas de los traslados de material es la posible pérdida de información que puedan sufrir los ejemplares ${ }^{206}$.

Uno de los mayores problemas para las piezas es cómo conseguir un ambiente idóneo para ellas tanto en su traslado como en el lugar de destino ${ }^{207}$. Pero es un riesgo que hay que

206 MONTERO, Antonio, DIÉGUEZ, Carmen. "Problemática y organización de los traslados de fondos paleontológicos". En ANABAD, Tomo 41, $\mathrm{N}^{\circ}$ 2, 1991, p. 168 .

207 Modelos de cajas preparadas para controlar vibraciones, temperatura y humedad son: Suspension Packing System (reduce vibraciones hasta un 80\%), Suspension Clima Systemß (condiciones 
afrontar ya que las exposiciones temporales son necesarias para toda institución museística y los traslados de sede (ampliación de espacio, reformas...) son inevitables.

Otro factor a tener en cuenta es la elección del itinerario y el medio de transporte. ¿Aire, tierra o mar?, ¿avión, tren, ferrocarril, camión o barco?. Elegir uno u otro dependerá tanto de las características de las obras dimensiones y peso- como del lugar de destino.

No es lo mismo un trayecto corto dentro del mismo país con una obra de pequeño formato, que un largo recorrido con una pieza de gran peso y dimensiones. Para el primer caso, lo más frecuente es utilizar el transporte terrestre 208 normalmente el camión ${ }^{209}$-, mientras que para el segundo se usa el avión ${ }^{210}$ o el barco.

Una vez en la nueva ubicación, el problema lo tiene ahora el museo receptor de la obra, donde hay que encontrar

\footnotetext{
climáticas óptimas), Data Logger de impacto Sockbug, cajas con tecnología GPS.

208 Algunas empresas de transporte, embalaje, montaje y diseño de exposiciones son EMBAMAT (WWw.embamat.com), TTI (WWW.ttitransport.com), SIT (WwW.sit-spain.com) y AlcoArte (www.alcoarte.com).

209 Deben de poseer una carrocería térmica y semiblindada, sistema de detección y extinción de incendios, aire acondicionado, control ambiental en la cabina, trampilla elevadora, sistema de seguimiento GPS y estar dotados de suspensión neumática para evitar vibraciones. En algunos casos se requiere de seguimiento policial.

210 Para obras de gran volumen y peso el avión puede ser un inconveniente, ya que en algunos casos el tamaño de las puertas de las bodegas no son lo suficientemente grandes como para poder transportarlas.
} 
un lugar para guardar los embalajes, analizar el estado de conservación de la obra -por si ha sufrido daños-, aclimatarla a su nuevo espacio y registrar los datos referentes a su nuevo lugar y posibles deterioros que pueda sufrir.

En el caso de que el almacén del museo en el que se vayan a depositar los embalajes vacíos no pueda mantener una temperatura y humedad adecuada, éstos deberán aclimatarse entre veinticuatro y cuarenta y ocho horas a las nuevas condiciones de la institución.

Para concluir, podemos decir que unas buenas condiciones de conservación en el almacenaje, durante la manipulación de las obras, en su transporte y exhibición, harán que éstas puedan ser disfrutadas y contempladas por la sociedad durante más tiempo.

Todos los factores anteriormente comentados son realmente imprescindibles y han de tenerse en cuenta en cualquier institución museística, ya que los beneficiados son los bienes que pertenecen a nuestro Patrimonio. 


\subsection{LA SEGURIDAD, CONSERVACIÓN Y ÁREAS ESPACIALES EN LOS MUSEOS}

La desconfianza es madre de la seguridad.

Aristófanes ${ }^{211}$

El término seguridad proviene del término latino securitas. Cuando hablamos de seguridad nos referimos a que algo o alguien se encuentran seguros, fuera de peligro y sin riesgo. Una seguridad al cien por cien no existe, por lo que prevenir y evitar los riesgos es primordial.

Como ya sabemos, el museo conserva sus fondos con el fin de transmitirlos en las mejores condiciones posibles a las generaciones que se avecinan. De tal manera que se verá en la responsabilidad de proteger, conservar, investigar y difundir el Patrimonio a toda la sociedad. Para ello deberá encargarse del aspecto de la seguridad y protección que en él se depositan, el propio edificio -y el espacio circundante-, así como velar por la seguridad de sus trabajadores $y$, por supuesto, de sus visitantes.

Muchas veces se han considerado los museos como unos espacios ideales. Sin embargo, en el momento en el que se comienzan a plantear las cuestiones relacionadas con la

211 Dramaturgo y comediógrafo griego (444 a. C - 385 a. C). 
seguridad, el tema se complica por las propias limitaciones que poseen estas instituciones ${ }^{212}$.

La seguridad y la conservación en los museos son dos funciones que están estrechamente relacionadas, por eso es necesario no separar las acciones relacionadas con la seguridad de la conservación preventiva.

Numerosos expertos creen que la seguridad es uno de los factores más importantes que el museo debe tener en cuenta. La destrucción, pérdida o cualquier otro accidente causado en los objetos que expone significaría un importante daño no sólo para el museo sino para toda la sociedad.

La razón de ser de un museo es su colección y para ello debe de estar preparado para actuar en cualquier momento y ante cualquier situación de peligro para conservarla y mantenerla en el mejor estado posible. Tener una correcta planificación en el trabajo es fundamental, de este modo disminuirán los riesgos, se evitarán deterioros y pérdidas innecesarias.

Es cierto que la seguridad no se puede aplicar a todos los museos por igual, ya que cada uno tendrá unas características y necesidades diferentes por lo que deberá diseñarse específicamente según cada institución. La opinión

212 Jornada: Seguridad en los museos $y$ edificios de valor patrimonial. ICOM Argentina, CICOP Argentina, Banco Provincia de Buenos. 21 de octubre de 2009, Perú. En Noticias del ICoM Argentina, Número año 3 I, Diciembre de 2009. http://icom.newspoint.com.ar/online.php?S1=7\&idu=2347 (Consultado el 15 de agosto de 2010). 
y visión de cada experto que pueda intervenir sobre estas actuaciones es imprescindible para que la seguridad en el museo sea lo más completa y eficaz posible.

Como señala el código deontológico del ICOM, los museos deben garantizar la protección, documentación y promoción del patrimonio natural y cultural de la humanidad. El órgano rector debe garantizar condiciones de seguridad adecuadas para proteger las colecciones contra el robo y los daños que pudieran producirse en vitrinas, exposiciones, almacenes $y$ lugares de trabajo, así como en el transcurso de transporte $e^{213}$.

Esta actividad deberá estar dirigida por el Jefe o Director de Seguridad, pero en el caso de que la institución no contara con esta figura serán los Conservadores los que se encarguen de esta tarea bajo el mando del Director del museo, quien verdaderamente se encarga de la seguridad y organización de toda la institución.

Entre las tareas del Conservador se encuentran la del mantenimiento de la colección, el control de las condiciones climáticas y lumínicas, la exhibición de las piezas, el almacenaje, depósito y manipulación de las obras, así como del embalaje de las mismas, su transporte y el estudio del público visitante, entre otras.

Los principales objetivos de un Departamento de Seguridad de un museo -si lo hubiere- son la investigación, el desarrollo de nuevas tecnologías y la innovación. Todo ello, como es lógico, con el fin de obtener mejoras en este

213 Código de deontología del ICOM para los museos, 2006. Título 1, artículo 1.7 . 
ámbito. Al mismo tiempo debe de ser muy eficaz e implantar estrategias y acciones de seguridad referentes a la organización, a la técnica y a los factores humanos ${ }^{214}$.

Igualmente, este Departamento debe tener bien claro su ámbito de actuación con el fin de anticiparse a los hechos delictivos que pudieran suceder en el museo y lograr de este modo que el visitante disfrute su estancia gracias a los sistemas de vigilancia pero sin llegar a sentirse incómodos por un exceso de observación del personal de sala.

Según Jesús Alcantarilla, Director de Seguridad del Museo Picasso (Barcelona), las funciones del Departamento de Seguridad deben estar diseñadas para:

- Inculcar (el sentido de la misión del museo).

- Informar (el mandato del museo).

- Dirigir (los esfuerzos hacia la consecución de las metas).

- Favorecer (la consecución de los objetivos).

- Evaluar (el cumplimiento de las tareas del museo)215.

Vimos con anterioridad que algunos de los riesgos que ponen en peligro un museo son la contaminación atmosférica, el público, la luz o la humedad, pero hay otros como el incendio, el robo y el vandalismo, que quizás son los que más daños provoquen en las obras, ya que se puede producir una

\footnotetext{
214 ALCANTARILLA, Jesús. "La seguridad en los activos y actividades del Patrimonio Histórico Artístico". En Seguritecnia, Revista decana independiente de seguridad. $\mathrm{N}^{\circ}$ 329, abril 2007.

http://www.bormart.es/articulo seguritecnia.php?id=1394\&numero=329 (consultado el 16 de agosto de 2010). 215 Ibídem.
} 
pérdida total o parcial de ellas que en muchos casos es irreparable $e^{216}$.

Así, antes de aplicar cualquier medida de seguridad es necesario realizar un análisis previo de todos los riesgos posibles que pueden aparecer en un museo.

Cada uno de ellos deberá estudiarse por separado ya que muchas veces las medidas de seguridad son incompatibles unas con otras. Por ejemplo, para el robo existen gran cantidad de sofisticados sistemas de protección, pero esto no es suficiente si no se controla y se atiende constantemente las obras, las normas o los métodos de exhibición de la propia institución.

Además, se tendrá que tener en cuenta los recursos económicos con los que dispone la institución para poder llevar a cabo una correcta seguridad.

Hablando del robo y el vandalismo, un elemento realmente importante e imprescindible dentro de un museo es la ficha de inventario. Al ser la función principal de la institución proteger y controlar -tanto legal como físicamente- los bienes que alberga, el inventario debe de estar en una zona restringida al acceso del público y constar de unas condiciones de seguridad máximas. Pues su pérdida traería a la institución graves consecuencias. De este modo, deberá estar duplicada, guardarse en cabinas a prueba de humedad y resistentes al fuego para evitar su destrucción ${ }^{217}$.

216 BRAVO JUEGA, Isabel. "Un capítulo fundamental en la Museología: la seguridad en los museos". En ANABAD, XXXII, 1982, No 3, p. 319. 217 Ibídem. p. 321. 
Robert Tillotson afirma al respecto,

Los inventarios de control de la totalidad de los fondos de un museo -a través de una detallada catalogación, registro y documentación actualizada de su situación y movimientos- son de crucial importancia para la seguridad. Es preciso comprender que el mantenimiento y actualización de los ficheros no sólo tiene un efecto disuasor contra el robo, sino que suele ser, además, el único modo de recuperar el objeto robado ${ }^{218}$.

Actualmente existen en algunos museos los Planes de Protección de Colecciones ante Emergencias. Esto se debe a que existe más interés en crear y diseñar soluciones ante posibles situaciones de peligro y emergencia, ya sean provocadas por el ser humano o por la propia naturaleza.

Según Paloma Acuña ${ }^{219}$, escasos museos españoles cuentan con un riguroso Plan de Emergencia, ya sea para evacuar las obras de la institución como para saber cómo actuar en caso de acciones de delincuencia (robos o desapariciones de piezas), pero afortunadamente se está apreciando un aumento de esta actividad por la concienciación del personal de los museos que se preocupan cada vez más en realizar estos planes de emergencia ${ }^{220}$.

\footnotetext{
218 TILLOTSON, Robert G. La seguridad en los museos. Madrid. Ministerio de Cultura, 1980. p. 136.

219 Ex directora de Museos Estatales desde el año 1984 a 1989. Actualmente dirige la Real Fundación de Toledo.

220 "La falta de seguridad en los museos". Belt Ibérica S.A. El Portal de los Profesionales de la Seguridad y Emergencias.
} 
Este Plan consta de cinco documentos:

- Evaluación de riesgos

- Estudio del edificio

- Identificación y evaluación de riesgos internos y externos.

- Identificación de recursos

- Recursos humanos

- Recursos materiales

- Aplicación de medidas protectoras ante emergencias

- Medidas protectoras referentes a las colecciones

- Minimización de riesgos

- Jerarquización de colecciones

- Identificación de los bienes

- Medidas protectoras referentes a los recursos humanos

- Creación de equipos y asignación de personas

- Formación y programación de simulacros

- Medidas protectoras referentes a los recursos materiales

- Almacenes y botiquines de emergencia

- Proveedores, transportistas y otros recursos materiales externos

- Mecanismos de revisión

- Procedimiento operativo -se recogen todas las medidas que garantizan la operatividad del plan-.

http://www.belt.es/noticiasmdb/HOME2 noticias.asp?id=402 Miércoles, 8 de febrero de 2006 (Consultado el 11 de agosto de 2010). 
- Recuperación -actuaciones que se pueden prever para paliar las pérdidas en la recuperación de las colecciones siniestradas- ${ }^{221}$.

El programa de seguridad del museo incluye cumplir con unas normas de seguridad pública y privada. Respecto a la seguridad pública, es necesario elaborar un Plan de Relaciones Institucionales que tenga en cuenta la Comisaría de Policía, el parque de bomberos, el hospital, el puesto de la Guardia Civil y el Servicio Sanitario de Urgencias más cercano al museo. En relación con la seguridad privada, hay que tener en cuenta las acciones del personal vigilante de seguridad en los museos ${ }^{222}$.

El museo debe -o debería- contar con instrumentos y medios técnicos, electrónicos y humanos para una correcta protección, ya que muchas veces se tienen avanzados sistemas de seguridad pero nos olvidamos de lo importante que son los recursos humanos.

En cuanto a medios técnicos y electrónicos hablaríamos de sistemas de detección de incendio ${ }^{223}$, detector de llamas, alarmas, mangueras, dispositivos de evacuación, extintores, sensores de movimiento, vigilancia electrónica, eliminación del humo, sectorización del edificio con puertas blindadas,

221 CULUBRet, Bárbara, HeRNÁNDEZ, Marta, HidALGo, Encarnación, MARTÍNEZ, Marina, RALLO, Carmen. Guía para un Plan de Colecciones ante Emergencias. Madrid. Ministerio de Cultura, 2008.

222 Programa de Seguridad. Ministerio de Cultura.

http://www.mcu.es/museos/docs/MC/PM/programas5.pdf (consultado el 16 de agosto de 2010).

223 Los hay de muy diversos tipos: iónico para humos y gases, termostático y termovelocímetro ópticos. 
telecámaras, códigos de acceso por zonas, rociadores automáticos, cristales blindados...

En cuanto a los recursos humanos es importante que todo el personal de la institución tenga conocimientos de cómo utilizar los diversos sistemas de emergencia además de saber cómo evacuar al personal o el simple hecho de coger una pieza y trasladarla a un lugar seguro en caso de urgencia.
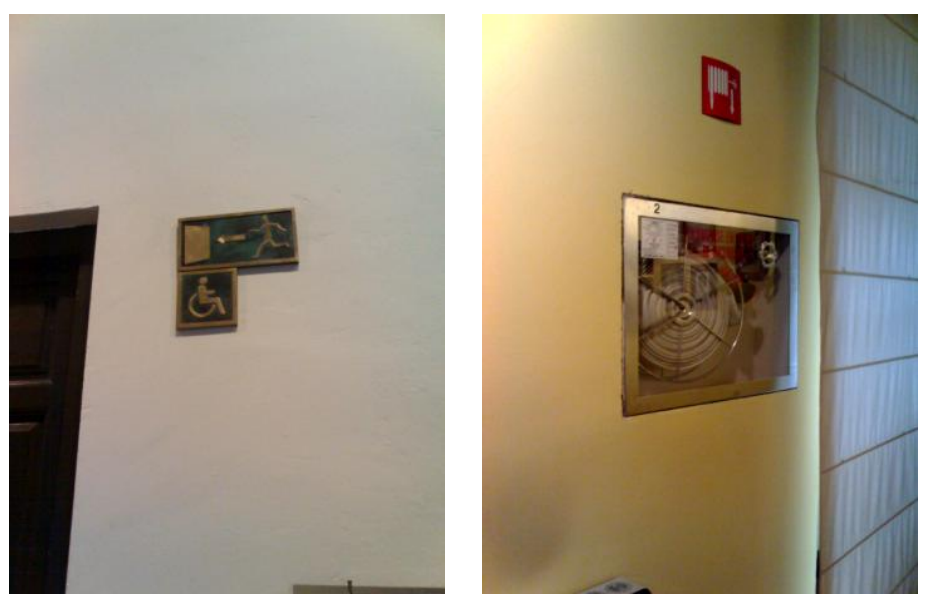

Figura 16. Algunos sistemas de seguridad de un museo -señalizaciones y manguera de extinción de incendiosFotos de la autora

Es recomendable que todos los trabajadores (vigilantes, administrativos, personal de mantenimiento, conservadoresrestauradores...) estén preparados para llevar a cabo el Plan de salvamento de las colecciones donde se establezcan prioridades sobre qué tipos de objetos se rescatan primero, cómo y bajo qué condiciones. Esta actuación debe pensarse con 
todo detalle para asegurar su buen funcionamiento, asignando a cada miembro del personal un papel a realizar ${ }^{224}$.

Además, se debe enseñar dónde poder encontrar las herramientas y útiles necesarios como: escaleras, llaves de reserva de vitrinas y puertas, material de embalaje, así como saber dónde se encuentran los lugares seguros para poder trasladar las piezas ${ }^{225}$.

En caso de incendio es esencial evitar el nerviosismo y centrarse en las tareas de alarma y evacuación dejando que sean los expertos quienes tomen este tipo de decisiones ${ }^{226}$.

De este modo, es fundamental concienciar al personal de la institución sobre estos riesgos y problemas, por lo que se deberían realizar periódicamente cursos sobre la seguridad en los museos que traten temas básicos como la evacuación ante incendios o el correcto manejo y uso de extintores.

Por tanto, no sólo se debe depender de los sistemas electrónicos de seguridad, sino que además, el vigilante de sala y el personal de seguridad deben realizar correctamente su trabajo y centrarse en su actividad de guardia del museo.

\footnotetext{
224 "Seguridad en el Museo". En Revista Digital Nueva Museología. Febrero de 1994.

http://www.nuevamuseologia.com.ar/seguridad en el museo.htm

(consultado el 16 de agosto de 2010).

225 Ibídem.

226 SÁEz LARA, Fernando. "La seguridad en los museos". En Curso de Iniciación a la Museología, Centro de enseñanza virtual Liceus. Madrid. Universidad de Alcalá, 2007.
} 
Todos los museos deben contar con este tipo de empleados para que controle sus piezas y sus visitantes, e impidiendo que éstos ocasionen algún tipo de deterioro en ellas. Para ello, es necesario que supervise e inspeccione constantemente todas las salas del edificio, por lo que deben ser muy buenos observadores y prever reacciones repentinas en visitantes sospechosos.

Algunas de las razones que obligan a los museos a mejorar sus sistemas de vigilancia y seguridad es la obsolescencia que sufren, la negligencia y descuido por el propio personal de la institución, y como no, a la gran cantidad de ladrones y traficantes de obras o al desconocimiento de la sociedad sobre la importancia y el valor de nuestro Patrimonio y sus respectivas leyes de protección.

La clave del éxito es tener una correcta vigilancia, un personal atento y formado, y unos avanzados sistemas de seguridad.

Como sabemos, en el museo se distinguen cuatro espacios diferenciados por su uso. La zona pública sin colecciones, la zona pública con colecciones, las zonas no públicas con colecciones y por último, las zonas no públicas sin colecciones. De este modo, la seguridad del museo dependerá de estos espacios, ya que no se utilizarán los mismos sistemas en las salas expositivas o en los almacenes, que en la zona de recepción, talleres o zonas de ocio y descanso del visitante. 
Veamos qué tipo y condiciones de seguridad se requiere en cada una de ellas ${ }^{227}$.

La primera zona -pública sin colecciones- no requiere de controles de seguridad ni ambientales muy específicos ni sofisticados ya que se trata de las tiendas, restaurantes, cafeterías o vestíbulos que pudieran existir en un museo.

La zona pública con colecciones son los espacios que hay que prestar más cuidado y atención porque son en los que conviven público y piezas de arte -salas de exhibición-. Por ello es el área más exigente, difícil y cara de mantener ya que presenta unos niveles de acabado y presentación sofisticados de cara al público con los controles más rigurosos del edificio en lo que respecta a ambiente y seguridad ${ }^{228}$.

En los laboratorios, almacenes, talleres de conservación o de restauración, en definitiva, las áreas no públicas con colecciones, se mantienen los mismos niveles de seguridad -no tan sofisticados- que la comentada anteriormente, aunque existen más controles ambientales.

En las áreas sin colecciones y que no son públicas se tienen menos sistemas de seguridad, ya que son espacios de trabajo y además no se custodian piezas.

Además, se podrían diferenciar tres niveles de seguridad dependiendo de las diferentes zonas del museo. Un primer nivel interior -zonas no públicas con colecciones- que

227 ALCANTARILLA, Jesús. Idem.

228 LORD, Barry, LORD, Gail Dexter. Manual de gestión de museos. Barcelona. Ariel, 1998. p. 152. 
estaría siempre protegido, un segundo nivel intermedio -zonas no públicas sin colecciones- igualmente protegido, y por último, un nivel exterior -los espacios perimetrales del museo- que tienen un gran nivel de protección, vigilancia y seguridad ${ }^{229}$.

\section{SEGURIDAD Y SALUD DEL TRABAJADOR}

Es imprescindible mantener seguro el lugar de trabajo y los objetos que en él se depositan, pero velar por la salud y la seguridad de los trabajadores es igual de importante, ya que son vidas humanas y cumplen unas tareas realmente necesarias dentro de la institución. Por ello es conveniente protegerlos ante posibles enfermedades profesionales, al igual que vigilar por su bienestar tanto físico como psíquico.

Los conservadores y restauradores pueden sufrir multitud de accidentes laborales que pueden dañar los sistemas de su organismo al estar en un continuo contacto con aparatos, productos, instrumental y agentes biológicos (hongos, bacterias, partículas en suspensión...). Por lo que pueden sufrir riesgos de tipo químico, ambiental o postural.

Quizás uno de los riesgos más peligrosos a los que se somete este trabajador es el relacionado con las sustancias y productos tóxicos que utiliza durante las tareas de conservación y restauración. La limpieza de las obras o su consolidación, son actividades donde es necesario utilizar

229 ALCANTARILLA, Jesús. Idem. 
productos químicos 230 - la mayoría de ellos disolventes- que pueden producir graves daños para la salud como el white spirit, acetona, tolueno, ácido clorhídrico, benceno, ácido sulfúrico, biocidas, hidróxido sódico -sosa cáustica-, silicato de etilo, xileno, N-hexano...

Una exposición prolongada a estas sustancias ocasiona molestias generales en el organismo (dolores de cabeza, vómitos, mareos...) además de producir alteraciones en el sistema nervioso, por lo que es muy importante usar correctamente estos materiales.

Otros riesgos que puede sufrir el conservadorrestaurador son: quemaduras por productos químicos y abrasivos, cortes, golpes, caídas, intoxicación -aguda o permanente-, electrocución, daño en la vista por proyección de partículas, daño en el oído por un excesivo ruido de la maquinaria, dermatofitosis ${ }^{231}$, contaminación electromagnética -rayos x, láser, ultravioleta...-, posturales -los TME 0 también llamados Trastornos músculos-esqueléticos ${ }^{232}-.$.

Para evitar y reducir este tipo de lesiones -los TMEen el trabajo es importante mantener una correcta postura de

\footnotetext{
230 Se pueden clasificar en anestésicos, corrosivos, irritantes, nocivos, radiactivos, contaminantes biológico, inflamables, explosivos, carburantes, peligrosos para el medio ambiente, tóxicos... 231 Es una infección de la piel y uñas producida por un grupo de hongos llamados dermatofitos. En este caso suelen afectar a las uñas .

232 Son lesiones de músculos, tendones, nervios y articulaciones que se localizan con más frecuencia en el cuello, la espalda, hombros, codos, muñecas y manos.
} 
aquellas zonas donde el impacto de movimiento es mayor, en este caso, los brazos, espalda y cuello.

Algunas recomendaciones para esta actividad son:

\section{- Riesgo en el taller o laboratorio}

- Mantener ordenada la zona de trabajo y revisar diariamente su limpieza.

- Mantener las zonas de tránsito sin obstáculos para evitar tropiezos.

- Planificar antes de realizar cualquier tarea.

- Utilizar un mobiliario ergonómico.

- Realizar estiramientos musculares y pequeños descansos.

- Controlar los desechos residuales ${ }^{233}$.

- Tener en cuenta:

- La posición relativa del trabajador con la ventilación e iluminación.

- El plano de inclinación de la mesa.

- La disposición de las mesas y la distancia con respecto a las paredes y otros obstáculos.

- La altura de taburetes y mesas -regulables dependiendo de la tarea-.

- No comer ni beber en el lugar de trabajo.

- No guardar alimentos en el frigorífico destinado a sustancias químicas.

- Evitar beber el agua del grifo del taller.

- Lavarse las manos antes y después del trabajo.

- Vestir con la indumentaria de trabajo necesaria (batas, mascarillas, guantes, gafas protectoras...).

233 Para los restos de botes usados y demás residuos es necesario ponerse en contacto con la Unidad de Calidad Ambiental. 
- Avisar al responsable del taller en caso de malestar.

- Acudir directamente al médico en caso de contacto con alguna sustancia peligrosa y producto químico.

- Mantener una buena iluminación y ventilación (extractores localizados).

- Deberá estar dotado de:

- Extintores contra incendios ${ }^{234}$

- Polvo químico seco

- Polvo líquido polivalente

- Gas carbónico

- Agua presurizada -para fuegos que no son de origen eléctrico-

- Agua nebulizada

- Armarios para productos tóxicos

- Señales de evacuación

- Alarma antiincendios

- Suelo no resbaladizo

- kit de derrames de productos químicos ${ }^{235}$.

234 Se utilizarán dependiendo de la zona y el tipo de fuego. No usar extintores de CO2 ni agua en zonas donde haya obras, ya que son nocivos para éstas.

235 Se trata de un material absorbente en forma de tapete realizado en celulosa de algodón prensado o algún producto químico absorbente. Se coloca alrededor del charco para evitar que se esparza el líquido. Son polivalentes, por lo que sirve para todos los productos. Si no disponemos de este kit de derrames, dependiendo del producto, se utilizará arena -en caso de disolventes orgánicos- que se eliminará posteriormente como residuo peligroso, o agua -si no son disolventes-. 
Fichas Internacionales de Seguridad Quimica

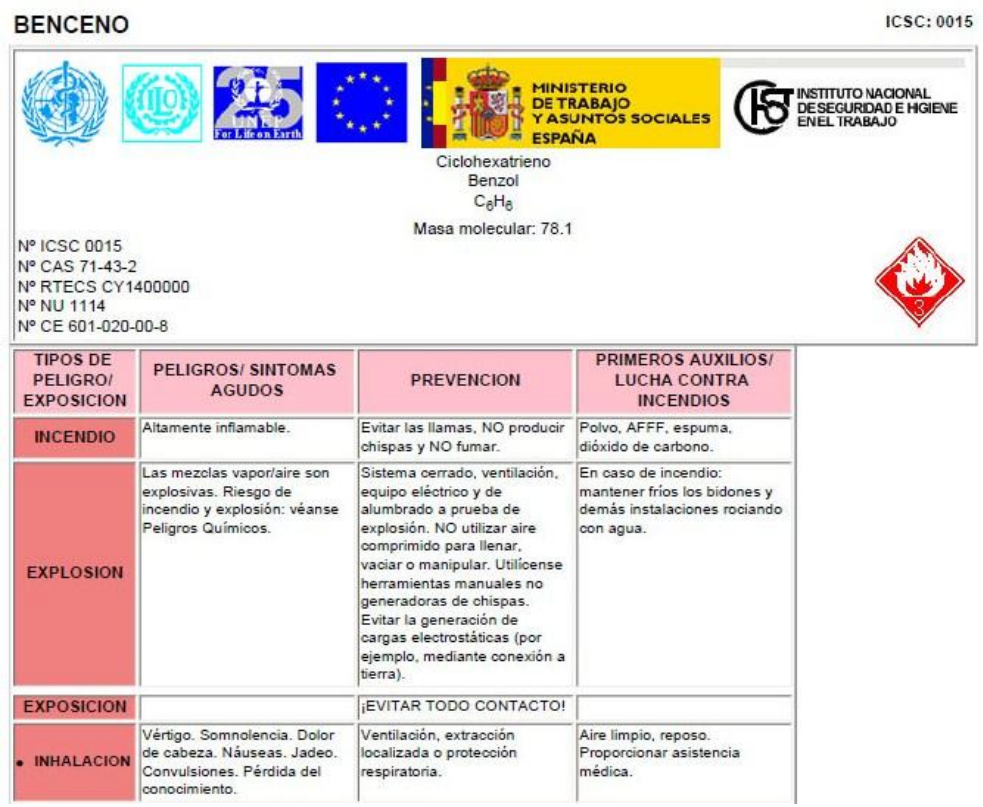

Figura 17. Ejemplo de una parte de la ficha de seguridad (FDS). Instituto Nacional de Salud e Higiene en el Trabajo, Gobierno de España

- Riesgo de almacenamiento

- Utilizar mobiliario de seguridad, con alarmas y eliminación de gases.

- Registrar y etiquetar los productos que se encuentran almacenados.

- Agrupar el material por sus características, peligrosidad y compatibilidad.

- Mantener los botes y contenedores cerrados.

- Riesgo químico

- Informarse sobre los productos químicos y su peligrosidad. 
- Etiquetas: composición del producto químico, nombre del distribuidor, pictogramas...

- Fichas de datos de seguridad (FDS) .

- Fichas internacionales de seguridad química $(\text { FISQ) })^{236}$.

- Riesgos:

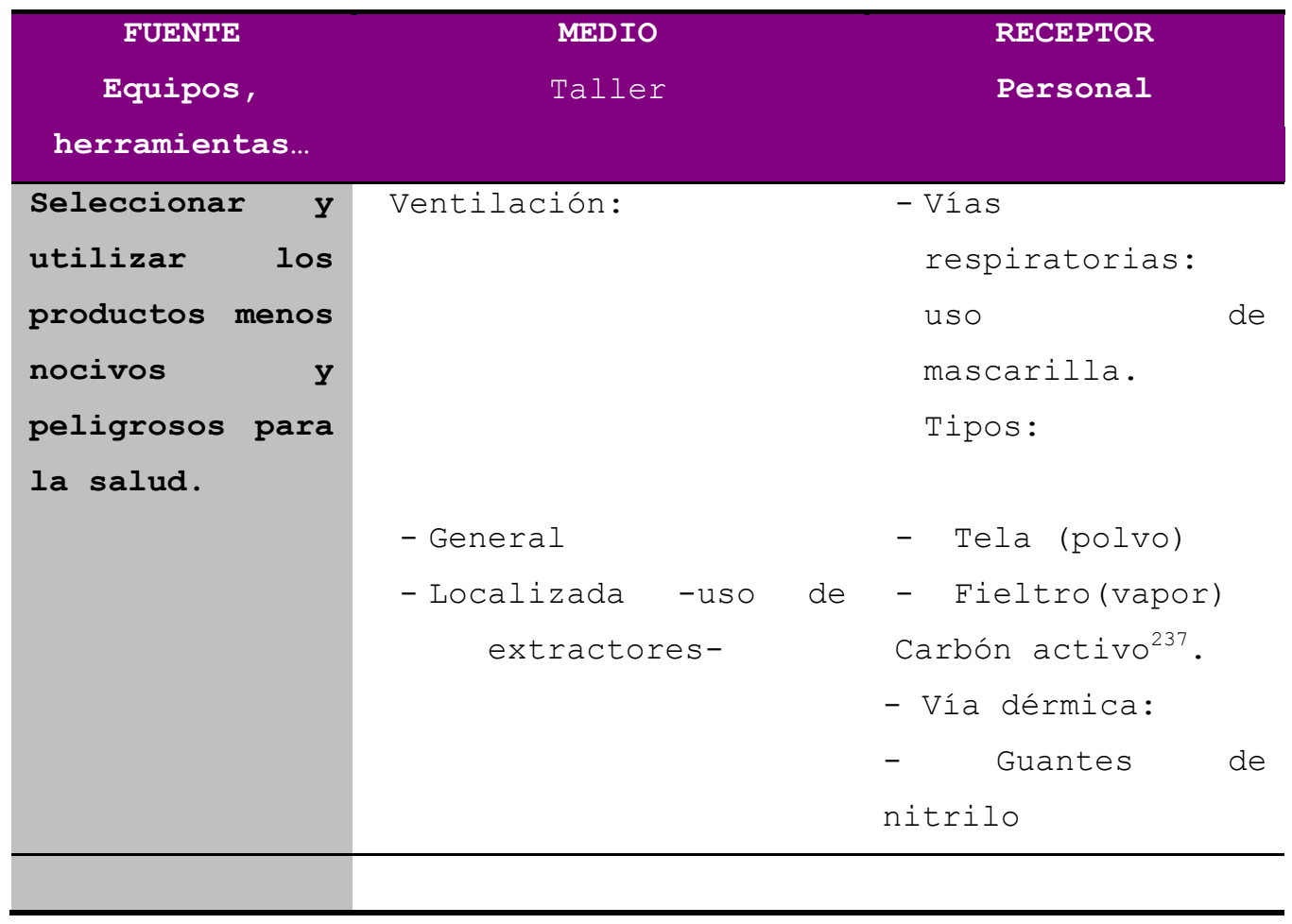

Tabla 2. Posibles riesgos provocados por herramientas, en el taller y el personal.

236 No informan del producto en sí, sino de la composición química pura.

237 Es un material derivado del carbón que posee la cualidad de ser extremadamente poroso, de ahí su fabricación para el uso de filtros. 


\section{- Riesgo ambiental (lumínico y acústico)}

- Aspectos lumínicos:

- Distribuir la iluminación homogéneamente en todo el taller.

- Colocar las luces fluorescentes paralelas a las ventanas.

- Calidad de iluminación en restauración.

- Que no deteriore la obra.

- Que no moleste a la vista. Sin reflejos ni deslumbramientos (entre 1500 y 1000 $\operatorname{lux}$.

- De bajo consumo (para el medio ambiente) .

- De intensidad adecuada.

- Que sea lo más parecida a la luz natural. Aquí dependerá el tipo de luz y el índice de reproductividad cromática $(\operatorname{IRC})^{238}$.

- Acondicionamiento acústico:

238 Indica el índice de reproductividad del color de un objeto, por lo que debemos usar lámparas con una buena reproductividad cromática. Las incandescentes son mejores que las halógenas ya que éstas deterioran la obra y no son buenas para la vista. Emiten radiaciones ultravioleta que hacen que se oxiden los materiales. Otra lámpara recomendable son las de luz día, ya que reproducen mejor el color. 


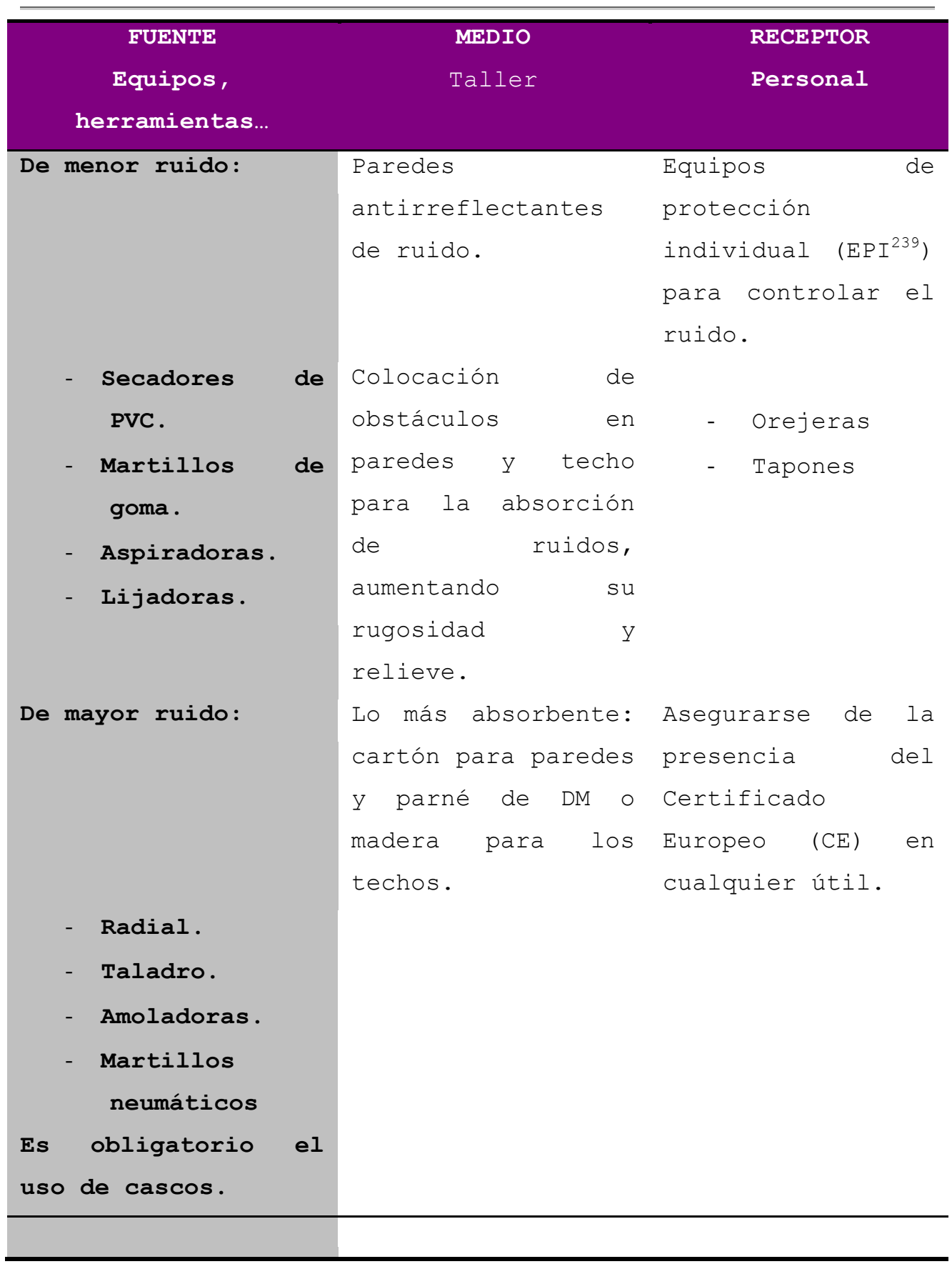

Tabla 3. Acondicionamiento acústico del taller

239 Equipo de protección para el trabajador. 
Igualmente, no hay que olvidar los impactos en la salud provocados por la organización de la institución, el ritmo y el tiempo de trabajo. Ejemplos de este tipo son el Burn out ("estar quemado"), el estrés, el acoso laboral, el aislamiento grupal o el Mobbing ${ }^{240}$, aunque estos problemas no son exclusivos de los profesionales de los museos.

En definitiva, podemos decir que cada vez más, en los últimos años, se está tomando conciencia de la necesidad y la importancia de la seguridad en los museos. Ya que no sólo está en juego unos bienes de valor económico, sino que además poseen un importante valor cultural, tradicional, emocional y religioso. Es un Patrimonio único que nos pertenece a todos y por tanto hay que velar por su seguridad y conservación.

En palabras de Isabel Bravo, cuanto más elevado sea el grado de seguridad de un museo, más estará en condiciones de presentar el patrimonio cultural a las generaciones venideras ${ }^{241}$.

240 Acoso moral producido por parte de los compañeros de trabajo.

241 BRAVO JUEGA, Isabel. Idem. 


\title{
6. LOS DEPARTAMENTOS DE CONSERVACIÓN- RESTAURACIÓN
}

\author{
En estos capítulos trataremos sobre las diferentes \\ características de los Departamentos de Conservación- \\ Restauración de las instituciones museísticas.
}

Para ello, comenzaremos haciendo una breve referencia acerca de su origen y funciones de ámbito general e internacional, para detenernos a analizar los Departamentos de Conservación-Restauración españoles.

Concluiremos aclarando y explicando la aparición y evolución de la figura del Conservador-Restaurador de Bienes Culturales, haciendo especial hincapié en el personal restaurador en España.

\subsection{ORIGEN Y FUNCIONES DE LOS DEPARTAMENTOS DE CONSERVACIÓN-RESTAURACIÓN}

Los Departamentos o áreas de Conservación-Restauración -según se denominen en cada museo- van adquiriendo cada vez más importancia dentro de las instituciones museísticas. 
Veamos en qué circunstancias se crean y cómo han ido evolucionando a lo largo del tiempo, sus características y funciones principales, así como el personal profesional de este tipo de departamentos.

Finalizaremos comentando brevemente los rasgos principales que definen los Departamentos de Conservación y Restauración de los museos españoles.

\section{HISTORIA}

A principios del siglo XX el espacio dedicado a esta labor se denominaba "taller". Un lugar más bien enfocado a la artesanía artística, pero especializada, en donde las condiciones de trabajo y los medios disponibles eran realmente escasos. El material era mínimo y el personal que lo formaba no tenía bien claro cuál era su función, aparte de carecer de una formación académica y de unos criterios de actuación definidos ${ }^{242}$.

Más tarde y con el paso de los años, los museos han ido evolucionando tanto en medios como en personal, se han ido creado los diferentes tipos de departamentos -investigación, documentación, difusión, conservación...- y, por ende, estos espacios han mejorado considerablemente.

En los años setenta y ochenta del siglo XX, algunos museos no estaban divididos ni organizados en diferentes departamentos como ocurre en la actualidad. En algunas

242 dÁVIlA BUItrón, Carmen, MORENO CIFUentes, Ma Antonia. "El laboratorio de restauración del MAN". En ANABAD, Tomo 43, $\mathrm{N}^{\circ} 3-4$, 1993. p. 165 . 
ocasiones este "aparente desorden" respondía a la propia filosofía de la institución, como en el Centro Pompidou de París (Francia) donde trabajaban de una manera interdisciplinar sin departamentos independientes. Por el contrario en otras instituciones como el Museo de Arte Moderno de Nueva York se funcionaba a través de departamentos convirtiéndose en los años setenta en un modelo admirado y capaz de establecer el camino a seguir para conservadores $y$ museos de todo el mundo occidental ${ }^{243}$.

Se podría decir que el origen de estas áreas o Departamentos de Conservación y Restauración surge de la necesidad de actuar e intervenir en las obras antiguas pertenecientes a la realeza debido a su mal estado de conservación.

Entre los años 1930 a 1960 van a ir apareciendo nuevos laboratorios, además de ir modernizando los ya creados, aunque hasta los años setenta no se puede hablar de un laboratorio de restauración propiamente dicho. Ejemplos de éstos son el Instituto de Restauración de Bruselas (IRPA), el Restauro de Roma, los Laboratorios de la Nacional Gallery de Londres, los laboratorios del Museo de Arte Moderno (MOMA) de Nueva York, los del museo del Louvre en Francia, el Instituto de Conservación de Ottawa ${ }^{244} \ldots$

A partir de estos momentos se irán haciendo públicas las actuaciones que se realizan en los laboratorios, e igualmente, se colaborará y se establecerán relaciones con

243 SCHUBERT, Karsten. El Museo. Historia de una idea. Desde la Revolución Francesa a hoy. Granada. Turpiana, 2008. p. 60. 244 SEDANO ESPIN, Pilar. "El área de restauración. Museo Nacional del Prado. Madrid". En Restauración \& Rehabilitación, N 109, 2008. 
otras instituciones. Es el caso del Museo del Louvre que en el 1964 publica bajo el impulso de André Malraux un compendio de los hallazgos del Laboratorio y comienzan emisiones por televisión ${ }^{45}$. Se crean contactos de colaboración con otros centros como los de Oxford, Florencia, Munich, Ámsterdam, Washington (Conservation analytical Laboratoy del Smithsonian), Paul Getty de Los Ángeles o el Instituto Canadiense de Conservación $(\text { ICC })^{246}$.

También hay que destacar la importancia que ha tenido y tiene- la aparición de la informática en los años ochenta y la implantación de las nuevas tecnologías en los museos.

Estos nuevos adelantos nos permiten divulgar las investigaciones científicas en un nuevo formato digital. Las revistas, catálogos y libros en papel van quedando obsoletas y lo que va imperando en los años noventa es la difusión de la información en CD-ROM, DVD e internet.

Del mismo modo, se irán creando programas informáticos para recopilar toda la información que se genera en los diferentes centros $y$ en los mismos departamentos de la institución. Estas nueva tecnologías han permitido realizar simulaciones de daños en las obras y observar las restauraciones ya realizadas en las mismas, así como examinar las técnicas empleadas o los dibujos subyacentes.

\footnotetext{
245 MORENO RODRÍGUEZ, Rosa. "Laboratorio de Investigación en el Museo del Louvre". En Cuadernos de Restauración, N² 2, 2000. p. 55. 246 Ibídem.
} 
Para Víctor Hugo López ${ }^{247}$, el siglo XXI ha coincidido a nivel mundial con un nuevo momento en la realidad museística internacional. Esta nueva realidad social y económica los ha obligado a transformarse en instituciones dinámicas y más sostenibles económicamente, por lo que se han visto en la necesidad de transformarse y renovarse a todos los niveles ${ }^{248}$.

Así, estos cambios se han visto reflejados en diferentes áreas del museo: en la administración, en la estructura y organización de los diversos departamentos, en el trabajo interno, en las instalaciones y equipamientos, en la seguridad...

De esta manera, en los Departamentos de ConservaciónRestauración de los diferentes museos se han producido grandes e importantes mejoras en su estructura interna, instalaciones y personal. Mejorando así, la planificación en el trabajo, la metodología y la comunicación entre los trabajadores.

\section{FUNCIONES}

Estos departamentos tienen como función principal preservar y conservar sus colecciones para mantenerlas en el mejor estado posible para así asegurar su supervivencia en el futuro.

\footnotetext{
247 Conservador-restaurador de escultura del Victoria and Albert Museum (Londres).

248 LÓPEZ BORGES, Víctor Hugo. "Planificación, la clave del éxito en el departamento de conservación de escultura del V\&A". En Actas del III Congreso del GEIIC. La conservación infalible: de la teoría a la realidad. Oviedo, 21-23 Noviembre, 2007. p. 342.
} 
Por tal motivo, las actividades que se llevan a cabo en estos departamentos son:

- La conservación preventiva (control de la humedad, luz, temperatura...) tanto de las obras expuestas en el museo como las ubicadas en el almacén.

- El mantenimiento y supervisión diaria de las piezas en exposición y almacenaje para evitar posibles daños futuros.

- La restauración de los bienes que integra la colección -en los casos que sean necesarios-.

- La investigación, documentación -registra la ubicación de las piezas en las salas y almacenes del museo- yestudio de las obras.

- La realización de informes de exposiciones, del estado de conservación de las piezas -por motivo de nuevo ingreso, préstamo o restauración- y la documentación de las intervenciones de conservaciónrestauración que se lleven a cabo en ellas (escrita y gráfica).

- El control de los préstamos de obras a otras instituciones.

- La supervisión del embalaje, desembalaje de las obras y el acompañamiento de las mismas hasta su destino -no en todos los casos-.

- Informar a la sociedad sobre las restauraciones, avances e investigaciones realizadas en el Departamento (publicaciones, videos, cursillos, conferencias, charlas, talleres, visitas...).

Además, no debemos olvidar los trabajos de colaboración e investigación con diferentes centros y laboratorios de química, física y biología, así como la realización de 
proyectos por parte de los profesionales de la institución para estudiar a artistas u obras en concreto que terminarán en posibles publicaciones.

Al respecto, Pilar Sedano y Ma Antonio Moreno defienden que los laboratorios de química, física y biología deben estar dentro del mismo Departamento, ya que el trabajo debe realizarse en equipo con los diferentes profesionales que lo componen por la necesidad de conocer la composición físicoquímica de las obras, su estado de conservación o la naturaleza de las sustancias que las integran ${ }^{249}$. Aunque lo habitual es que estos laboratorios sean externos a la institución.

Como ya se ha referido en otras ocasiones, no sólo este Departamento debe conocer y prestar atención a los diferentes sistemas de conservación de las obras de la institución, sino que todas las áreas funcionales o departamentos del museo (documentación, investigación, seguridad, difusión...) deben incorporar hábitos de trabajo de carácter preventivo, puesto que la prevención es la única manera de enfrentarnos con eficacia al deterioro natural de las colecciones.

El espíritu de prevención, la actitud de anticiparse al deterioro, se inserta con naturalidad en el trabajo de todos los departamentos del museo 250 .

249 MORENO CIFUENTES, Ma Antonia, SEDANO ESPIN, Pilar. "La investigación en los laboratorios de restauración de museos históricos". En ARBOR, Tomo CLXXXII, No 717, enero-febrero, 2006. p. 87 .

250 MUÑOZ CAMPOS-GARCÍA, Paloma. "La conservación en el museo. Conservación preventiva y criterios para la restauración". En Curso de Iniciación a la Museología, Centro de enseñanza virtual Liceus. Madrid. Universidad de Alcalá, 2007. p. 6-7. 
Debido a la importancia que tienen estos departamentos y las funciones que desempeñan, es necesario regirse por unas normas y unos procesos de trabajo.

En primer lugar, una vez seleccionada la obra que se va a restaurar -por su mal estado de conservación o salida del museo- el Departamento de Conservación necesitará recopilar toda la información almacenada sobre la pieza: ficha de inventario, fotografías, informes anteriores de restauración y análisis, bibliografía, nombre de la obra, procedencia, fecha de entrada al museo, las salidas realizadas de la institución, ...

Una vez obtenida la información necesaria, se realiza un estudio de diagnóstico donde se elegirán los tratamientos más adecuados y se documentará toda la intervención de la obra.

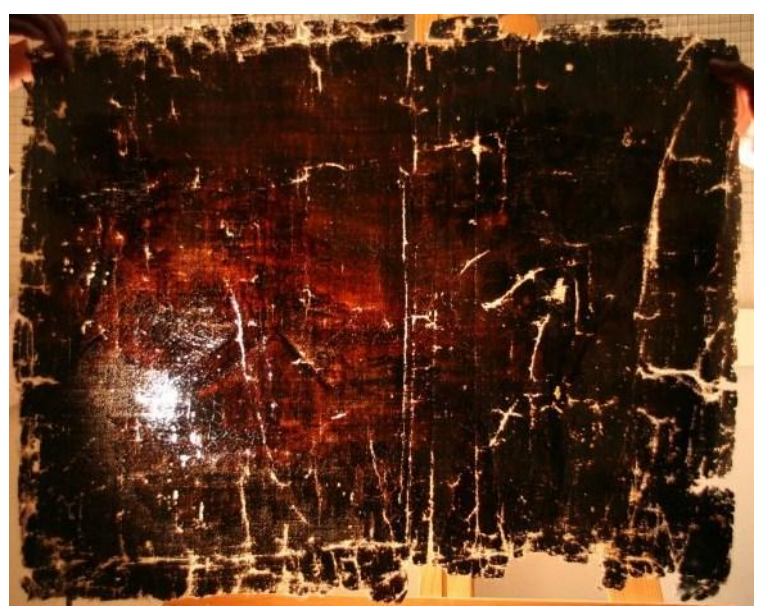

Figura 18. Fotografía con luz transmitida a una pintura sobre lienzo Foto de la autora 
Esta labor continuará hasta el final del proceso y se deberá mantener un seguimiento posterior -informe de conservación preventiva- para asegurar el mantenimiento del objeto en las mejores condiciones posibles.

Para ello, el restaurador completará una ficha de diagnóstico 251 estructurada normalmente en ${ }^{252}$ :

- Fecha de reconocimiento, localización de la obra, denominación, tema/iconografía, autor, atribución y bibliografía, fecha/cronología, dimensiones, propiedad y gestión, nivel de protección y el personal de contacto.

- Características técnicas.

- Estado de conservación.

- Intervenciones.

- Observaciones, fecha de reconocimiento y equipo responsable.

El encargado de la intervención deberá llevar al día el diario de restauración, donde consten todos los procesos de tratamiento y pruebas a realizar, los materiales e instrumental utilizados, los productos empleados y sus concentraciones, las fechas de las intervenciones, las posibles incidencias -ya sean positivas o negativas-, cambios que se vayan observando -por mínimos que sean-, dudas e incógnitas, croquis y dibujos de la obra... De tal forma que toda la información quedará registrada en un documento muy útil y accesible al personal de la institución.

251 Ver anexos.

252 El tipo de ficha variará dependiendo de cada restaurador. 
Posteriormente la pieza se trasladará al taller o área de fotografía donde será sometida a una documentación gráfica: macrofotografía, fotografía con distintos tipos de luces (transmitida, rasante, infrarroja, ultravioleta)...

Como se ha comentado anteriormente, este trabajo se irá realizando durante el proceso de intervención del objeto.

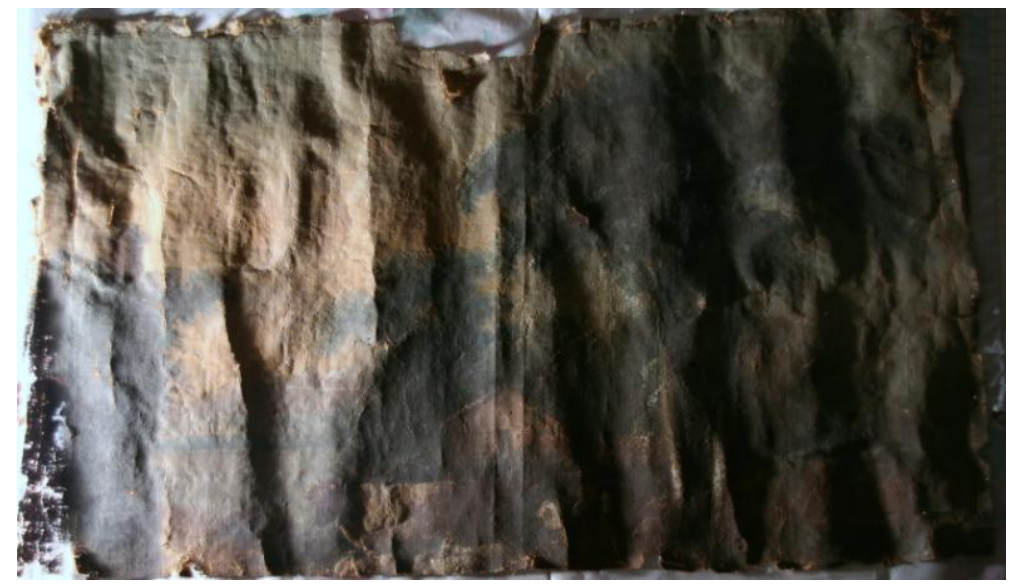

Figura 19. Documentación gráfica de una obra pictórica sobre tela con luz rasante Foto de la autora

Una vez documentada la obra gráficamente, es necesario realizar un análisis químico en el Laboratorio del Museo -si lo tuviere- 0 en otros centros de investigación especializados. Con esto lo que se pretende es conocer y analizar en profundidad la composición y estructura de la pieza, es decir, aquellos elementos que no podamos ver a simple vista (materiales utilizados, técnica empleada, imágenes y dibujos subyacentes, elementos ocultos, intervenciones anteriores...). 
Y todo ello, como afirma Rosa Moreno, preservando a toda costa la integridad de la obra, sin dañarla, sin tocarla $a^{253}$.

Sobre las características y tareas que se realizan en este Laboratorio hablaremos más adelante.

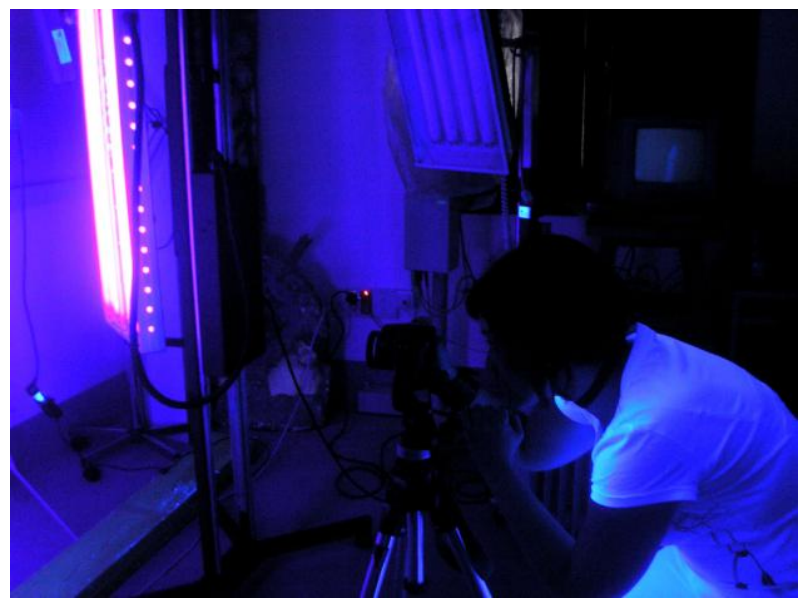

Figura 20. Fotografiando una pintura sobre lienzo con luz ultravioleta

Foto de la autora

Una vez analizada y estudiada la pieza a través de los métodos físico-químicos, se procede a intervenir en la propia obra. Concluida la restauración, ésta pasará a formar parte de la colección permanente, a una exposición en otra institución o a los almacenes del museo. Siempre teniendo en cuenta, como hemos comentado, que la conservación de la obra continúa después de su intervención, tanto en las salas de exposición, como en el almacenaje y su transporte hasta el nuevo destino.

253 MORENO RODRÍGUEZ, ROsa. Idem. p. 52. 


\section{LOCALIZACIÓN Y ESTRUCTURA}

La renovación, adaptación y rehabilitación de instituciones museísticas se ha centrado, con frecuencia, en los edificios del pasado, siendo un recurso muy utilizado a lo largo de los años. La propia naturaleza de inmueble, si se trata de un edificio antiguo o de nueva planta influirá a la hora de ubicar el Departamento en el recinto.

Como decimos, uno de los problemas con los que se tiene que enfrentar el museo es el lugar donde ubicar el Departamento. Muchos de ellos son recintos antiguos, mal acondicionados y situados en calles de difícil acceso a vehículos grandes, por lo que resulta complicado adaptar el inmueble a las necesidades que requiere la institución, y más aún a los lugares destinados al tema que nos afecta, la Conservación y Restauración de los Bienes Culturales.

Con el paso del tiempo se han ido modificando las condiciones y el emplazamiento de este departamento dentro de las instituciones museísticas. Anteriormente se instalaban en diferentes zonas del museo, sótanos y plantas bajas, en el ala sur-este o sur-oeste...

Según comenta Pilar Sedano, los "talleres" de restauración estaban situados en la planta baja del museo -el sótano-, un lugar sin una correcta iluminación y ventilación. Sin espacio suficiente donde no era posible realizar los trabajos en las condiciones adecuadas ${ }^{254}$.

254 SEDANO ESPIN, Pilar. Idem. p. 17-18. 


\section{Hoy en día los Departamentos se instalan -lo más} correctamente posible- en las plantas superiores del museo, situándolos cerca -o con buenos accesos- a las colecciones permanentes y a los almacenes para permitir una movilidad de las piezas sin producir grandes riesgos para las mismas.

Así, el lugar contará con abundante luz natural y ventilación, con suficiente espacio y equipamiento para realizar las labores de conservación y restauración en unas condiciones adecuadas.

Ejemplos de éstos son -tanto nacionales como internacionales- el Thyssen-Bornemisza, el Museo Nacional de Reina Sofía, la National Gallery de Washington, el Guggenheim de Nueva York, o el Museo de Arte Moderno (MOMA) de Nueva York, entre muchos otros ${ }^{255}$.

De tal forma que este espacio deberá organizarse adaptándolo según las necesidades del trabajo a realizar. Al ser un lugar en continua ampliación tendrá que ser lo más espacioso posible y de gran altura, ya que habrá que tener en cuenta el peso y el tamaño de las piezas a restaurar, así como las posibles incorporaciones de nuevas áreas, mobiliario o equipamientos.

Igualmente, tendrá que contar con pocos obstáculos -o ninguno- que impidan el correcto movimiento de obras de gran formato.

Este Departamento debería estar integrado por una zona de administración o despacho para llevar a cabo los informes

255 Ibídem. 
de los tratamientos de las obras así como atender a profesionales, un laboratorio de análisis físico-químico, los diferentes talleres (escultura, pintura, marco, papel, madera...) y una biblioteca especializada en conservación y restauración -aunque cuente con pocos volúmenes- ya que servirá de gran ayuda a la hora de consultar cualquier dato e información que sea necesario.

Estas nuevas condiciones han supuesto una gran mejora tanto para la organización y labor del Departamento como del personal, que ponían en peligro sus vidas al poder sufrir intoxicaciones por una insuficiente aireación del lugar.

\section{LABORATORIOS Y/O TALLERES}

Como afirman Carmen Dávila y $\mathrm{M}^{a}$ Antonia Moreno, en general, son muy pocos los datos de que se dispone en lo referente a los laboratorios de restauración de los museos, lo que hace más dificil encontrar bibliografía acerca del montaje, disposición, acondicionamiento, mobiliario, dotación, distintas plantillas... de estos departamentos, así como de su historia, es decir, su creación, evolución y desarrollo a lo largo de las diferentes etapas del museo en que se hallan'256.

Hiroshi Daifuku257, Hodges ${ }^{258}$, Robert Muller Organ ${ }^{259} \circ$ Slabczynski ${ }^{260}$ son algunos investigadores que han tratado de

256 DÁvilA BUItRón, Carmen, MORENO CIFUentes, Ma Antonia. Idem. p. 165.

257 DAIfUKU, H. "Instalación del laboratorio. Ejemplo de un programa de ayuda de la UNESCO a países de las regiones tropicales". En La Conservación de los Bienes Culturales. París, 1979. pp. 89-101. 
forma general sobre el tema de la instalación y montaje de laboratorios, aunque son artículos de breve extensión y aportan consejos de carácter general 261 .

El primer laboratorio de museo -ya desaparecido- se creó en el Staatliche Museen de Berlín en el año 1833. Pero el verdadero movimiento de creación de laboratorios en los museos se produjo concluida la Primera Guerra Mundial (1918), como el laboratorio del Museo Británico de Londres. Posteriormente, otros museos continuaron con este ejemplo abriendo en 1925 el laboratorio del Museo del Louvre (Francia), el Museo de Bellas Artes de Boston en 1927 ol Museo de Arte Metropolitano de Nueva York (1930) ${ }^{262}$.

Lo que sí está claro es que hasta entrados los años setenta no se puede hablar de un Laboratorio de restauración propiamente dicho, sino que eran, como hemos comentado anteriormente, talleres artesanales especializados ${ }^{263}$.

Se crean en los museos por la necesidad de mantener la colección en un estado óptimo y adecuado de las colecciones,

258 HODGES. "Instalación del laboratorio. Equipo y operaciones fundamentales". En La Conservación de los Bienes Culturales. París, 1979. pp. 86-97.

259 ORGAN, R. M. Design for Scientific Conservation of Antiquities. Londres, 1968 .

260 SLABCZYNSKI, J. "Establishing a laboratory for restauration of paintings". En Museums Journal. LXIV-1, 1964.

261 FERNÁNDEZ IBÁÑEZ, Carmelo. "Montaje y funciones del laboratorio de conservación y restauración en un Museo de Arqueología". En Cuadernos de Prehistoria y Arqueología. No 23, 1996. p. 10.

262 FitzMAURICE MiLLs, John. Los Conservadores de obras de Arte. Centro de Información para Médicos, 1977. p. 23.

263 DÁVILA BUITRón, Carmen, MORENO CIFUENTES, Ma Antonia. Idem. 
además de conservarlas en el mejor estado posible sin padecer deterioros ni desperfectos.

En algunas instituciones el Laboratorio pertenece y está incluido en el área o Departamento de conservación, en cambio, en otros centros forma un departamento independiente, como es el caso de la National Gallery de Londres ${ }^{264}$.

El hecho de que un museo tenga instalado en el mismo recinto un Laboratorio de análisis físico-químico, así como un personal especializado y unos equipos adecuados, resulta esencial a la hora de restaurar e intervenir en las propias piezas de la institución.

Actualmente gran parte de los museos del mundo cuentan con este tipo de laboratorios en sus instalaciones. Es algo necesario e imprescindible que forma parte de la metodología de trabajo diaria de la institución, por lo que estos centros deberían estar dotados de uno -por pequeño que sea- donde poder realizar cualquier labor de conservación y restauración de sus fondos de una manera más rápida, completa y eficaz posible, ya que los problemas pueden aparecer en cualquier momento $y$ es necesario estar preparado para actuar rápidamente.

Uno de los centros que acoge un Laboratorio de análisis es el Museo del Louvre (Francia), que cuenta con un terreno de cinco mil metros cuadrados de superficie para estas labores, el mayor espacio en el mundo consagrado a la investigación en el terreno de la conservación y la restauración ${ }^{265}$.

264 SEDANO ESPIN, Pilar. Idem. p. 64.

265 MORENO RODRÍgueZ, Rosa. Idem. p. 51. 
Sobre los Laboratorios del museo Rosa Moreno relata,

...debe estar preparado para dar respuestas concretas a las demandas de la investigación científica, la histórica y la conservación. Así, por ejemplo, los problemas de autenticidad, el diagnóstico antes de una restauración, la creación científico-histórica de ficheros para los documentalistas $y$, además la informática en un doble sentido: creación de modelos informáticos para el estudio de las obras; y, la informática interactiva que permite, cruzando datos, obtener relaciones hasta ahora inéditas acerca de un pintor o una obra. Esto, naturalmente exige una continua puesta al día en los aspectos técnicos, adaptación a los modelos científicos más avanzados y, a la vez, la integración en un modelo humanístico que aúne la creación artística con la investigación científica ${ }^{266}$.

\section{- EMPLAZAMIENTO}

Tener unas buenas instalaciones y un lugar adecuado para albergar este tipo de Laboratorio en un museo es complicado y pocas veces el edificio es capaz de disponer de él.

Lo primero que hay que tener en cuenta es la búsqueda del recinto apropiado, el diseño y la organización del

266 Idem. p. 52. 
espacio, su climatización (iluminación, temperatura, humedad, ventilación...) e instalaciones eléctricas, así como la distribución del mobiliario, y la dotación de los equipos e instrumental necesarios según las características y naturaleza de la colección de la institución (ya sean materiales orgánicos e inorgánicos). Sin olvidarnos del grupo de trabajo integrado por profesionales de diferentes ramas del conocimiento (químicos, físicos, biólogos, restauradores, conservadores, historiadores...), su seguridad y salud laboral.

Ya hicimos referencia anteriormente que el espacio para el Departamento, al igual que para el Laboratorio, deberá ser amplio, situarse preferiblemente en el lugar más alto del edificio y con una gran altura. Además, es conveniente que se ubique lo más cerca posible de la zona de almacenaje, la sala de fotografía y los diferentes talleres -o con accesos directos-, y contar además, con un acceso fácil y sin barreras arquitectónicas (escaleras, pasillos muy estrechos...) para trasladar los objetos debidamente a las demás estancias del museo.

Igualmente habría que disponer de una sala anexa al Laboratorio donde poder almacenar las obras -o partes de éstas- más delicadas que se encuentren en proceso de análisis y restauración y no puedan realizar grandes movimientos ni sufrir cambios en sus condiciones climáticas.

Para ello esta estancia deberá contar con controles de humedad y temperatura dependiendo de las necesidades del material a almacenar ${ }^{267}$.

267 GÓMEZ-GIL AIZPÚRUA, Carlos. "Instalación de un laboratorio de restauración de materiales de procedencia subacuática". En Monte Buciero, $\mathrm{N}^{\circ}$ 9, 2003. p. 376. 
En cuanto a las instalaciones necesarias de agua, luz y aire comprimido deberán colocarse las tomas en el perímetro del recinto y adosadas a las paredes ${ }^{268}$.

\section{- ASPECTOS AMBIENTALES}

Respecto a las condiciones climáticas del Laboratorio, al estar situado en la zona más alta del edificio nos brindará una buena ventilación e iluminación natural.

Esto puede tener el inconveniente de que se tendrá que aislar térmicamente, tanto el techo como las paredes -si fuese necesario- frente al calor del verano y al frío del invierno. Para ello se instalarán aires acondicionados y calefacción central regulable.

La ventaja es que se podrá instalar fácilmente las salidas al exterior de los gases tóxicos que provocan ciertos productos químicos (adhesivos y disolventes) utilizados durante la intervención y que son altamente nocivos y dañinos para la salud.

\section{- Iluminación}

Lo ideal sería que el Laboratorio estuviera bien orientado a la luz solar y que contase con grandes y suficientes ventanas para tener una buena iluminación natural durante el trabajo. De esta manera se alumbraría todo el local de una forma uniforme.

268 Idem. p. 375. 
Habría que tener en cuenta que la luz debe entrar por el lado izquierdo del trabajador -en el caso de ser diestros, nunca de frente ni detrás para evitar deslumbramientos, ocultar o hacer sombra a lo que estemos realizando.

Para complementar este tipo de alumbrado natural se le sumará la luz artificial -general y localizada- distribuyendo de forma homogénea por todo el área focos y lámparas de luzdía ${ }^{269}$ (Day Light), además de disponer de otros tipos de tubos fluorescentes si es necesario. Se trataría de intensificar lumínicamente ciertas zonas más oscuras del espacio, como rincones y ángulos de difícil acceso, o ciertos aparatos de trabajo.

Las luces fluorescentes se colocarán paralelas a las ventanas haciendo que la luz sea más homogénea en el ambiente. Así, la luz del lugar dependerá de los factores y características de los focos, el número de ellos, su distribución y calidad.

El rango de iluminación ${ }^{270}$ (highlights) deberá estar al 80\%. Para estos espacios se necesitará una intensidad lumínica general de unos 500 lux para trabajos gruesos y unos 1000 lux para las labores finas y delicadas, como es el caso de las reintegraciones cromáticas.

Para medir la cantidad de iluminación del espacio se usarán equipos como los luxómetros ${ }^{271}$ y los ultravímetros ${ }^{272}$.

269 Bombillas que emiten una luz que se asemeja a la luz del día.

270 Iluminación mínima/iluminación máxima= 0,8.

271 Instrumento que mide la iluminancia de un ambiente.

272 Aparato de medición de las radiaciones ultravioletas. 
Para ahorrar energía y cuidar el medio ambiente es aconsejable el uso de bombillas de bajo consumo, aunque habría que tener en cuenta las ventajas e inconvenientes que tienen este tipo de luces.

Entre sus ventajas, destaca:

- Utilizan entre un 50\% y un 80\% menos de energía que una bombilla normal.

- Reducen el riesgo de calentamiento global y, en consecuencia, el cambio climático.

- Duran hasta diez veces más que una bombilla incandescente.

Veamos los inconvenientes de este tipo de iluminación.

- Su precio cuesta siete veces más que una bombilla normal.

- Produce daños en la salud -migrañas, vértigos, mareos...-, y en especial en el cerebro del ser humano, debido a la exposición prolongada al mercurio, metal que constituye la bombilla.

- En el momento de encenderse consumen mucha energía.

Otro factor a tener en cuenta es la cantidad de enchufes y tomas de corrientes en el recinto que deberán estar presentes en todas las paredes e inclusive a ser posible en el techo mediante railes. Tendrán suficiente potencia, toma de tierra y estarán protegidos. Será posible 
desconectarlos desde el cuadro eléctrico que controle el suministro a todo el laboratorio ${ }^{273}$.

\section{- Control climático y ventilación}

Sobre este aspecto, ya comentado anteriormente, sólo decir que el control de la temperatura y humedad es un elemento esencial en todo museo. En los laboratorios, donde se interviene en las propias piezas, su control debe ser extremo pues grandes fluctuaciones en sus condiciones climáticas haría que empeorase aún más su estado de conservación.

Así pues, se hace necesario realizar un estudio climático del lugar y disponer de aparatos que controlen y regulen estas condiciones ambientales, como son los ya referidos termohigrómetros, termohigrógrafos, higrómetros o termómetros, entre otros.

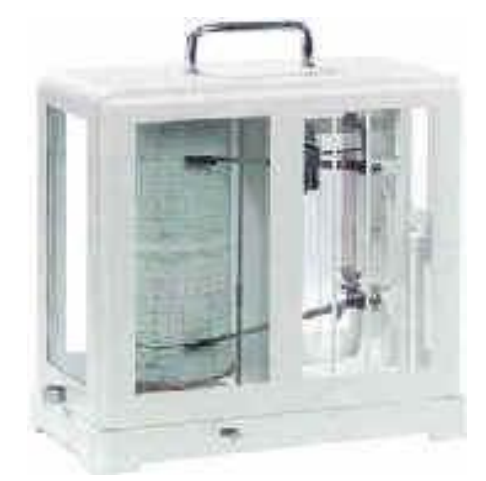

Figura 21. Termohigrógrafo

La revisión de este instrumental será diaria o semanal, observando las oscilaciones en su hoja de registro ${ }^{274}$.

273 FERNÁNDEZ IBÁÑEZ, Carmelo. Idem. p. 13. 
El edificio se encontrará sometido a la acción cambiante de la naturaleza y de los agentes externos (lluvia, viento, nieve...), lo que hará que influya en las variaciones de la temperatura y humedad del inmueble y, por tanto, de los objetos que albergue en él. La correcta instalación de las canalizaciones y bajantes de agua, y la colocación de aislantes térmicos en los muros y ventanas, son elementos esenciales para paliar o eliminar este problema por completo ${ }^{275}$.

Respecto a la renovación del aire del recinto, debido a la gran cantidad de gases y olores fuertes que se generan por los productos químicos utilizados, éstos deberán expulsarse al exterior a través de un tubo acoplado a un extractor ${ }^{276}$.

De la misma manera, según Carmelo Fernández ${ }^{277}$, como prevención contra posibles accidentes será conveniente instalar hélices extractoras colocadas en las ventanas. Su número variará, aunque siempre debería estar en proporción directa a la más rápida aireación del local, al crear entre todas ellas corrientes de aire suctoras ${ }^{278}$.

\section{- MOBILIARIO Y UTENSILIOS}

Cualquier Laboratorio, independientemente de las labores que se realice en él, debe estar bien preparado y

\footnotetext{
274 FERNÁNDEZ IBÁÑEZ, Carmelo. Idem. p. 23.

275 Ibídem.

276 FERNÁNDEZ IBÁÑEZ, Carmelo. Idem. p. 13.

277 Conservador-Restaurador del Museo de Palencia.

278 FERNÁNDEZ IBÁÑEZ, Carmelo. Idem. p. 17.
} 
equipado de un mobiliario y unas herramientas apropiadas para llevar a cabo el trabajo en unas circunstancias apropiadas.

En este caso, un Laboratorio de Conservación y Restauración de un museo, por la gran importancia que tiene en lo relativo a la preservación de las piezas, tendrá que estar bien dotado de un equipo científico y analítico, instrumental del que hablaremos más adelante.

Es un buen consejo el de Carmelo Fernández al referir que no hace falta adquirir material por el simple hecho de tenerlo y almacenarlo, o comprar porque otra institución lo tenga. Esto se puede solventar colaborando y compartiendo materiales y conocimientos con otros centros, laboratorios e instituciones ${ }^{279}$.

Aún así, el espacio se tendrá que separar dependiendo de si se realizan trabajos con materiales húmedos o secos.

Según Carlos Gómez-Gil Aizpúrua ${ }^{280}$, esta distribución del espacio se puede realizar mediante paneles móviles con el fin de separar las diferentes áreas de trabajo, diferenciando éstas en materiales inorgánicos y orgánicos, pudiéndose subdividir en zona húmeda y seca ${ }^{281}$.

En el primer caso, se aconseja adaptar el inmueble con suelos que aguanten el agua, fáciles de limpiar y con grandes desagües para la evacuación del agua. En el caso de los materiales pesados y de gran tamaño, se confeccionarán

279 Idem. p. 14.

280 Ex restaurador de la Subdirección Xeral de la Consellería de Cultura de Galicia.

281 GÓMEZ-GIL AIZPÚRUA, Carlos. Idem. p. 374. 
grandes tanques y el suelo se adaptará para soportar dicho peso ${ }^{282}$.

Para abastecer el local de agua corriente será imprescindible la colocación de varios grifos para agua fría y caliente. En el caso de limpiezas de obras que requieren el uso de agua sin impurezas o desmineralizada, se utilizarán depuradores o desmineralizadores ${ }^{283}$.

En este espacio será necesario disponer de material escurridor, piletas con encimeras, desagües protegidos para que no le ataque el vertido de residuos químicos, filtros para estos productos y receptáculos para el almacenaje $e^{284}$.

Para una mayor comodidad, se aconseja que la zona se encuentre revestida de baldosas cerámicas no esmaltadas, ya que son muy resistentes (a golpes, humedad, agentes químicos y biológicos), duraderas, antideslizantes y previene de la humedad evitando el desarrollo de gérmenes y bacterias.

Para la zona seca igualmente se tendrá en cuenta que el suelo no sea resbaladizo.

Para albergar la maquinaria como la cámara de anoxia ${ }^{285}$, la cuba de ultrasonidos ${ }^{286}$, la de ensayos climáticos o la

\footnotetext{
282 Ibídem.

283 FERNÁNDEZ IBÁÑEZ, Carmelo. Idem. p. 15.

284 Idem. p. 16.

285 Cámara en la que se realiza la desinsectación y desinfección de una obra al extraer el oxígeno del interior y sustituirlo por un gas inerte.

286 Aparato que consigue un gran nivel de limpieza en muy poco tiempo.
} 
cámara de vacío o liofilizadora (freeze-drying) ${ }^{287}$, se requerirán amplias zonas debido a su volumen y por la necesidad de prever terreno para la introducción de los materiales en dichas cámaras ${ }^{288}$.

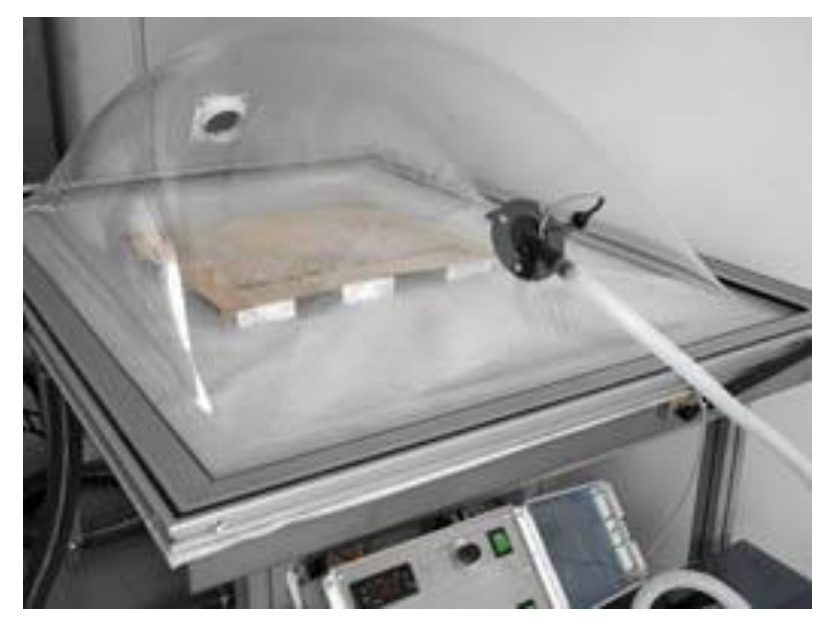

Figura 22. Cámara de anoxia.

Si dispone de cámaras frigoríficas para almacenar o conservar grandes piezas de origen orgánico que se hallen en proceso de restauración o análisis, habrá que controlar que la temperatura del interior no modifique bruscamente la del resto del Laboratorio. Para eso será necesario que la zona circundante se encuentre preparada para adaptarse termohigrométricamente a estas circunstancias.

Igualmente, un frigorífico casero servirá para mantener ciertos productos y materiales elaborados con sustancias orgánicas.

\footnotetext{
287 Cámara hermética que realiza el vacío del interior una vez introducido el objeto.

288 GÓMEZ-GIL AIZPÚRUA, Carlos. Idem. p. 374.
} 


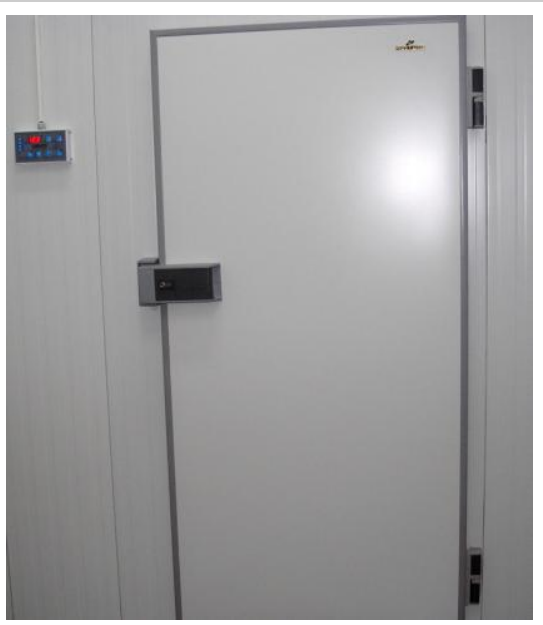

Figura 6. Cámara frigorífica para obras delicadas. Perteneciente al Museo de Bellas Artes de Granada

Foto de la autora

Imprescindible será la presencia de hornillas para calentar, trapos, papel, algodón, secadoras, menaje del hogar (cucharas, cuchillos, tenedores, morteros, recipientes de plástico de diferentes tamaños y herméticos, embudos, botes, cacerolas, planchas...), productos de limpieza básicos, pesos, báscula digital, balanza electrónica, agitador magnético, termómetro digital, material de trabajo mecánico (escalpelos, bisturís y hojas de recambio, tijeras, lápices, regla, agujas, lijas, cepillos, espátulas, brochas, hisopos...), pinceles, material óptico (lentes de aumento, cuentahílos ${ }^{289}$, lupas binoculares...), probetas, pipetas, vasos de precipitado, herramientas varias (tornos, microtornos, microtaladros, fresadoras, aspiradora, martillos, seguetas, tenazas, punzones, sierras, alicates, clavos, alambres, tuercas, grapadora, tornillos, tuercas, soldador eléctrico...), y un largo etcétera. La instalación de estanterías, vitrinas,

289 Especie de lupa que sirve para ver la trama y urdimbre de un tejido o pequeños detalles de otros materiales. 
armarios y cajoneras facilitará el almacenaje de estos utensilios.

En cuanto al armario de estanqueidad para productos químicos deberá ubicarse no demasiado lejos de la zona de trabajo para facilitar la labor de abastecimiento. Además, se indicará su situación y los productos que contiene con señalizaciones ${ }^{290}$.

Para mejorar las condiciones de seguridad del trabajador se recomienda que tenga instalado un extractor de aire y una alarma de aviso si el armario permanece abierto demasiado tiempo. De esta manera evitaremos contaminar el ambiente del taller con un exceso de vapores nocivos para la salud.

A ser posible se procurará colocar rejillas a nivel del suelo para que los disolventes desciendan y salgan al exterior al pesar más que el aire ${ }^{291}$.

Para las mesas, sillas, taburetes y caballetes será necesario que sean lo más confortables posibles para el trabajador, regulables en altura y de diferentes tamaños según las características de las piezas a intervenir.

\section{- Equipo de análisis químico}

Hoy en día las técnicas analíticas en conservación y restauración $y$, en general las nuevas tecnologías de otras

290 FERNÁNDEZ IBÁÑEZ, Carmelo. Idem. p. 22.

291 Ibídem. 
disciplinas, se encuentran en un continuo avance, desarrollo y evolución.

Es una gran ventaja el poder realizar en el propio Laboratorio del museo los diferentes exámenes y análisis químicos, físicos y biológicos de las obras. Aunque sabemos que esto puede resultar imposible en algunas ocasiones debido a lo difícil que resulta acceder a las nuevas tecnologías por su alto coste económico.

Como ya se comentó, la colaboración con otros investigadores, centros, empresas e instituciones de tecnología analítica suele servirnos de gran ayuda en estos casos.

Será necesario, por lo menos, poseer el equipo básico e imprescindible de trabajo, ya que no es realmente preciso abastecerse de todo el instrumental existente en el mercado para este tipo de estudios.

Carmelo Fernández recomienda que la adquisición de material pueda realizarse por etapas según las necesidades y el dinero disponible hasta completar el total de las susodichas necesidades ${ }^{292}$.

Muchas veces, por lo delicado que son este tipo de aparatos, es indispensable que el Laboratorio cuente con una sala aparte libre de vibraciones, con control autónomo de temperatura y humedad relativa, y con campanas de extracción de gases ${ }^{293}$.

292 FERNÁNDEZ IBÁÑEZ, Carmelo. Idem. p. 14.

293 GÓMEZ-GIL AIZPÚRUA, Carlos. Idem. p. 374. 
Organizar y aprovechar el espacio con el que se dispone resulta una tarea muy importante para trabajar en unas condiciones adecuadas, ya que se está manipulando un material muy delicado y costoso. Así, debemos hacer que el operario se encuentre cómodo y pueda desenvolverse sin problemas dentro del área de trabajo.

En cuanto a la maquinaria que deberá albergar el Laboratorio, ésta tendrá que servir para realizar los estudios de los diversos soportes y materiales en que están realizadas las obras.

A continuación se expondrán algunos de los equipos y técnicas de trabajo dedicados a estas acciones:

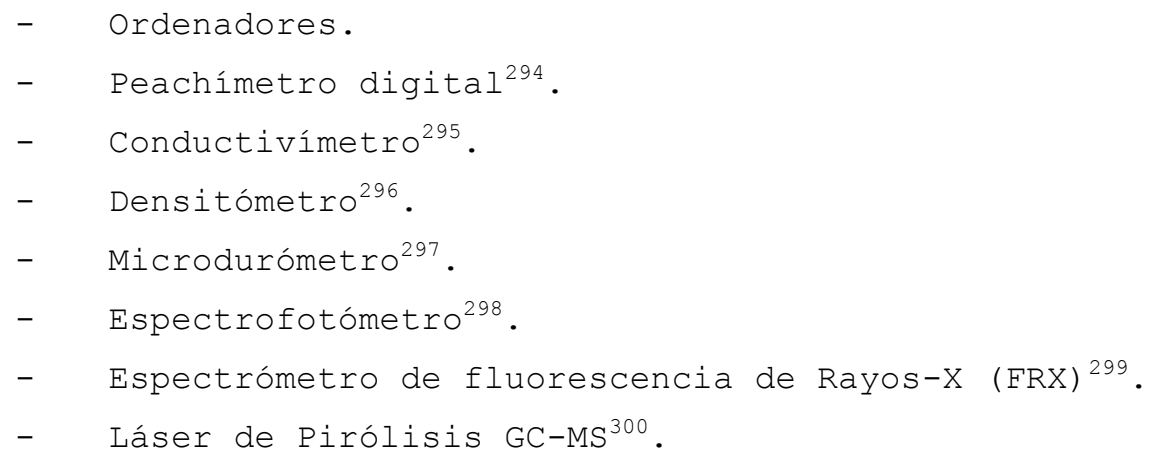

\footnotetext{
294 Aparato que mide el pH de un material.

295 Dispositivo que puede medir el pH, la conductividad, la salinidad y la temperatura.

296 Equipo que mide el grado de densidad óptica de un material.

297 Utilizado para el estudio de la dureza de diferentes materiales. 298 Instrumento usado para la cuantificación de sustancias y microorganismos.

299 Permite detectar y cuantificar la composición de una muestra irradiándola con Rayos $x$. Existen dos modalidades: modo dispersivo en longitud de onda (WDXRF) y dispersivo en energía (EDXRF).
} 
- Difracción de Rayos-X (DRX) ${ }^{301}$.

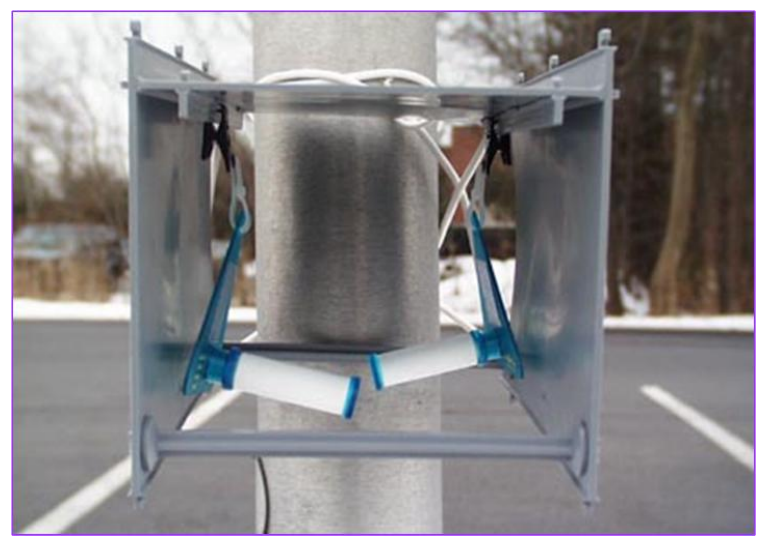

Figura 23. Análisis de gases por cromatografía iónica

- Microdifracción de Rayos-X.

- Microscopía óptica de luz transmitida y luz reflejada.

- Microscopía óptica por polarización y fluorescencia.

- Microscopía Electrónica de Barrido (SEM) ${ }^{302}$.

- Microscopía Electrónica de Barrido con un sistema de microanálisis por dispersión de energías de Rayos-X (SEM-EDX) .

- Microscopía Electrónica de Barrido Ambiental $(\mathrm{ESEM})^{303}$.

300 Produce la descomposición térmica de la muestra. Requiere un detector de masas para identificar los productos originados.

301 Para caracterizar materiales mediante el análisis cristalográfico de su estructura.

302 Tanto esta técnica como la Microscopía Electrónica de Barrido con microanálisis de Rayos-x, permiten el estudio de superficies de alta resolución, así como determinar con Rayos-X los elementos químicos presentes en una muestra. Además, ofrece la posibilidad de realizar microanálisis tanto cualitativos como cuantitativos. 
- Microscopía Confocal de Barrido (CLSM) ${ }^{304}$.

- Microscopía de fuerza atómica (MFA) ${ }^{305}$.

- Cromatógrafo306 de gases con un detector de espectrometría de masas.

- Cromatógrafo líquido de alta resolución con distintos sistemas de detección.

- Espectroscopía Infrarroja ${ }^{307}$.

- Espectroscopía Infrarroja por Transformada de Fourier ${ }^{308}$.

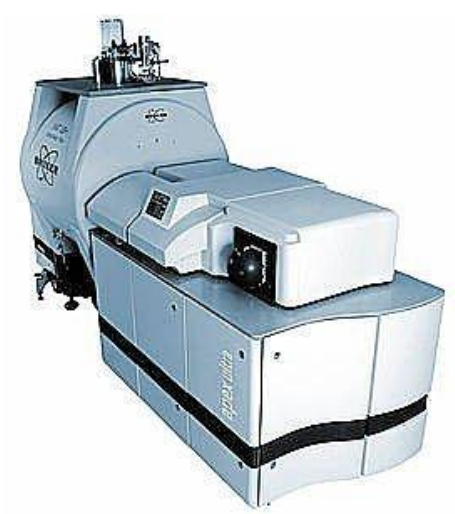

Figura 24. Espectómetro de masas

303 Técnica que estudia las superficies de distintos materiales gracias a su elevada resolución y profundidad de campo. Se puede trabajar en alto vacío, bajo vacío o ambiental.

304 Técnica que permite caracterizar materiales a escala macro, micro y nanométrica.

305 Usado para caracterizar materiales y determinar sus propiedades físicas. Proporciona imágenes de superficies tridimensionales con alta resolución.

306 Técnica analítica que permite caracterizar aceites secantes, resinas naturales, ceras, parafinas, proteínas, polisacáridos y colorantes naturales de diferentes materiales.

307 Permite identificar compuestos de un material y su composición.

308 Técnica que obtiene una mayor sensibilidad y resolución en los resultados respecto a la Espectroscopia Infrarroja. 
- Espectroscopía Raman ${ }^{309}$ (Raman ultravioleta, de luz visible, infrarrojo cercano y FT-Raman).

- Espectroscopía de Emisión Óptica (OES) ${ }^{310}$.

- Espectroscopía de Emisión de Plasma asociada inductivamente $(\mathrm{ICPE})^{311}$.

- Espectroscopía de fotoelectrones ${ }^{312}$.

- Microfluorescencia.

- Fluorescencia por Reflexión Total (TXRF) ${ }^{313}$.

- Microanálisis con Sonda de Electrones (EPMA) ${ }^{314}$.

- Rayos-X inducido por partículas (PIXE) ${ }^{315}$.

- Radiografía Neutrónica ${ }^{316}$.

- Difracción de neutrones ${ }^{317}$.

309 Técnica de alta resolución que permite identificar compuestos orgánicos e inorgánicos.

310 Utilizado en el análisis de composición de elementos.

311 Ha sustituido a la técnica de Espectroscopía de Emisión Óptica (OES) ofreciendo resultados más precisos.

312 Técnica que permite la identificación de compuestos sólidos superficiales.

313 Misma técnica que la fluorescencia convencional pero ésta sólo se requiere de unos microgramos de muestra, por tanto es menos destructiva.

314 Es una técnica de superficie que requiere muy poca cantidad de muestra, aunque la cuantificación es más dificultosa. Usada en cerámicas, vidrios y pigmentos.

315 Técnica no destructiva usada para la caracterización de materiales.

316 Técnica análoga a la radiografía tradicional, pero utiliza un haz de neutrones en lugar de uno de rayos-X. Usada para visualizar componentes químicos y estudiar la microestructura de un material. 317 Permite identificar y cuantificar las diferentes fases cristalinas presentes en una pieza. Ha sido inicialmente empleada para la caracterización de piezas cerámicas. 
- Radiaciones Gamma ${ }^{318}$.

- Técnicas de análisis con fuente de energía de radiación Sincrotrón ${ }^{319}$.

- Técnica de datación por radiocarbono (Carbono$14)^{320}$.

- Técnicas quimiométricas ${ }^{321}$.

- Equipos de digitalización (escáner de placas radiográficas y escáner de diapositivas) con sistemas informáticos acoplados para el tratamiento de las imágenes,...

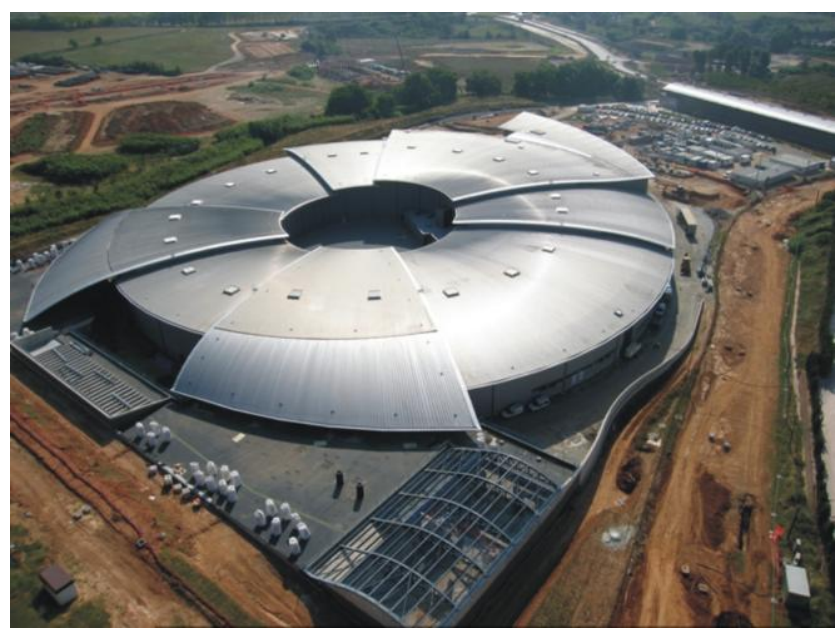

Figura 25. Laboratorio europeo de Radiación Sincrotrón, Grenoble (Francia)

\footnotetext{
318 Permite la eliminación de insectos, bacterias, hongos, larvas... del interior de las piezas con el objetivo de protegerlos de la degradación.

319 Es una radiación electromagnética generada por partículas cargadas en un campo magnético. Muy útil para estudiar la microestructura de la materia.

320 Técnica para conocer la edad de compuestos orgánicos.

321 Usada para la interpretación de resultados de muestras.
} 


\title{
- SEGURIDAD
}

Aunque ya hemos tratado de la seguridad en el museo con anterioridad, es importante hacer referencia sobre algunos consejos para prevenir riesgos en el Laboratorio, en los bienes que alberga y el personal que lo usa.

En cuanto a las instalaciones del lugar, se tendrán que tener en cuenta las características y naturaleza de los materiales utilizados en su fabricación. Por ejemplo, las puertas y ventanas que no sean de P.V.C serán de madera ignífuga para ofrecer protección contra el fuego. Las paredes deberán estar convenientemente tratadas internamente para retener las llamas el mayor tiempo posible en caso de producirse explosiones seguidas de un incendio 322.

Todo el espacio dedicado a esta labor de conservación y restauración deberá estar indicado con señalizaciones para actuar con rapidez ante situaciones de emergencia.

\begin{abstract}
Detectores de fuego -térmico o de humo-, alarmas antiincendios, pulsadores de alarma y extintores de diferentes características, como es natural, también serán imprescindibles. Siendo lo más aconsejable emplazar el detector o detectores en el techo y los extintores colgados de la pared, cerca del lugar o productos con mayor riesgo de explosión y/o inflamabilidad ${ }^{323}$.
\end{abstract}

322 FERNÁNDEZ IBÁÑEZ, Carmelo. Idem. p. 18.

323 Ibídem. 


\begin{abstract}
Un accidente puede suceder en cualquier momento inesperado y por eso un botiquín de primeros auxilios equipado con los elementos indispensables (gasas, tiritas, desinfectantes, crema para quemaduras, vendas, esparadrapo, colirios...) será de gran ayuda para solventar estos percances leves. Además, no nos debemos olvidar de revisar periódicamente los medicamentos para reponer los gastados o eliminar los ya vencidos.
\end{abstract}

Las fuentes lavaojos son igualmente importantes en caso de emergencia si hemos sufrido alguna salpicadura o derrame de productos tóxicos. En tal caso, de inmediato se acudirá al especialista médico ya que supone un alto riesgo para la vista. Se instalarán en lugares bien visibles y libres de obstáculos que impidan su inmediata utilización.

Para la seguridad de ciertos objetos de gran valor que se deposite en el lugar de trabajo, sería conveniente contar con una caja fuerte que podría tener inclusive una alarma incorporada. Su combinación numérica tan sólo debería obrar en poder del o de los conservadores-restauradores, jefes de sección y por supuesto de la dirección ${ }^{324}$.

Para evitar la contaminación acústica que producen ciertos aparatos e instrumental de alto nivel de intensidad de sonido (tornos, taladros, radiales, amoladoras...) sería apropiado acondicionar zonas para poder trabajar de una manera aislada e independiente del resto del lugar y así evitar ruidos y molestias innecesarias.

324 FERNÁNDEZ IBÁÑEZ, Carmelo. Idem. p. 27. 


\section{BIBLIOTECA Y ZONA DE ADMINISTRACIÓN}

Las bibliotecas han sido y siguen siendo uno de los elementos fundamentales en la formación e investigación del personal, de ahí la importancia de contar en el Departamento con una biblioteca actualizada y especializada que complementara los trabajos prácticos que se realizan en el taller y Laboratorio.

Si bien es cierto que no se pueden adquirir todas las publicaciones y revistas existentes en este ámbito del conocimiento, sería importante contar por lo menos con algunos volúmenes de libros, folletos, revistas y publicaciones, ya que nos serviría de gran ayuda a la hora de consultar dudas o problemas que se nos planteen durante los tratamientos.

Algunos museos permiten que esta sala de documentación sea visitable, previa cita, por el personal externo a la propia institución que requiera la consulta de un determinado ejemplar.

Algunos profesionales aconsejan que junto a la biblioteca se instale un pequeño despacho o zona de administración para atender y recibir a investigadores y expertos, además de realizar algunas labores manuales como presupuestos, consultas, proyectos, incorporación de los estudios e informes de los tratamientos realizados en las obras...

Verdaderamente no es un lugar imprescindible. Es más algunos pensarán que es totalmente prescindible, pero su 
utilidad es evidente y nunca se valora hasta que no se realizan ciertas labores sobre una mesa de despacho ${ }^{325}$.

\section{PERSONAL Y SU FORMACIÓN}

El máximo responsable de este Departamento es el Jefe de Restauración -variará dependiendo de cada museo-. En muchos casos son los propios restauradores de la institución, como ocurre en la Pinacoteca de Munich, el Georges Pompidou (Francia), el Museo de Arte Moderno de Frankfurt o el MOMA de San Francisco ${ }^{326}$, el que se encarga de la dirección del mismo.

Como sabemos, la restauración de los Bienes Culturales es un trabajo complejo que requiere la intervención de varios expertos. Además del conservador-restaurador será necesario contar con un equipo formado por profesionales de diferentes áreas de conocimiento: químicos, físicos, biólogos, historiadores del arte, arquitectos... aportando cada uno sus conocimientos y tratando, por tanto, la conservación y los bienes desde diferentes puntos de vista.

Siempre trabajando conjuntamente, en coordinación, intercambiando opiniones y ayudándose unos a otros. Evitando las tensiones y malos entendidos que se puedan producir en determinadas situaciones.

Como sabemos, colaborar y trabajar con especialistas de otras materias siempre resulta una tarea gratificante y enriquecedora.

325 FERNÁNDEZ IBÁÑEZ, Carmelo. Idem. p. 31.

326 SEDANO ESPIN, Pilar. Idem. p. 18. 
Estos empleados han de enfrentarse en su lugar de trabajo con todo un enorme cúmulo de objetos a tratar y además deberán atender a multitud de aspectos que procurarán no dejar de lado para que el ritmo del laboratorio no se vea alterado $y$ el trabajo no se acumule. En definitiva, sin llegar a ser un sistema de producción en masa, finalizar el ejercicio anual con unos resultados apreciables, científicamente aceptables $y$ que sean el reflejo de un sistema de trabajo eficaz ${ }^{327}$.

Uno de los problemas a los que se enfrentan algunos museos es la carencia de este personal. En muchos de ellos solamente cuentan con un restaurador que ha tenido que atender y ocuparse, debido a esta carencia, a diferentes tareas dentro de la institución.

Además, es fundamental que la plantilla del Departamento esté en continua formación para así ampliar sus conocimientos y ejercer su profesión de manera actualizada. Para ello deberán asistir a cursos, jornadas, seminarios y conferencias especializadas en este campo del conocimiento. De igual modo será enriquecedor el traslado temporal de expertos -tanto a nivel nacional como internacional- a otros centros e instituciones para intercambiar opiniones, información y experiencias.

Las becas siempre han cumplido un papel importante en nuestra sociedad. La creación de este tipo de ayudas dentro del Departamento permitirá admitir a estudiantes y a personal investigador de las diferentes especialidades de conservación

327 FERNÁNDEZ IBÁÑEZ, Carmelo. Idem. p. 24. 
Los Departamentos de Conservación-Restauración en los museos andaluces: estudio y análisis de casos

y restauración. Mejorando de esta manera el futuro de nuestro Patrimonio. 


\subsubsection{LOS DEPARTAMENTOS DE CONSERVACIÓN-}

\section{RESTAURACIÓN EN LOS MUSEOS ESPAÑOLES.}

Las funciones, características y el personal que opera en el Departamento de conservación-restauración del museo son muy similares tanto en los museos internacionales como los nacionales. Por tanto sólo diferenciaremos los rasgos más destacados que han definido los departamentos españoles.

\section{HISTORIA}

Con lo que respecta a España, el pensamiento ilustrado supondrá un cambio en el concepto del arte. Éste dejará de formar parte del poder y la religión para integrarse en el resto de la sociedad.

A raíz de las desamortizaciones eclesiásticas se crean organismos para gestionar el Patrimonio, como las Comisiones de Monumentos Históricos-Artísticos y los Museos Provinciales ${ }^{328}$.

De las Iglesias, conventos, monasterios, claustros o palacios, las obras pasan a pertenecer a estos museos o las Academias de arte que se crean para encargarse de su cuidado y conservación.

328 AntigüEdAd DEL CAstillo-OLIVAREs, María Dolores. "El Museo de la Trinidad y el origen del museo público en España". En Espacio, tiempo y forma, $\mathrm{N}^{\circ} 11,1998$. p. 392. 
Así, todas las obras artísticas van perdiendo el significado para el que fueron creados y pasan a ser objetos de estudio que la investigación sistemática del arte en España va incorporando en fases sucesivas ${ }^{329}$.

Debido al mal estado en que se encontraban la mayoría de las piezas se empiezan a realizar las restauraciones de estos objetos -finales del siglo XVIII, principios del XIX- y por consiguiente, se irán creando en los museos los diferentes talleres, laboratorios de análisis químicos y Departamentos dedicados a estas labores.

En los años cincuenta del siglo XX se muestra especial interés en los museos provinciales de Bellas Artes, reforzando el papel de sus patronatos y dotándolos de nuevos servicios; se publican sus guías, se instalan almacenes para albergar las obras y en algunos casos, se dotan con talleres de restauración ${ }^{330}$.

A través de las numerosas reuniones y congresos que se realizaron en estos museos, se definieron las principales líneas de actuación de cada uno de ellos pudiéndose consultar en sus Boletines periódicos, en las Memorias de los Museos Arqueológicos de España y en la Revista de Archivos, Bibliotecas y Museos ${ }^{331}$.

Muchos Departamentos han ido cambiando y modificando su línea de investigación. Pero hoy en día, en la gran mayoría

\footnotetext{
329 Idem. p. 367.

330 VILLAFRANCA JiMÉNEZ, María del Mar. "Los museos andaluces: pasado, presente y perspectivas de futuro". En Revista de Museología, $\mathrm{N}^{\circ}$ 13, febrero de 1998. p. 34.

331 Ibídem.
} 
de los museos e instituciones de España se trabaja e investiga con los mismos criterios que en el resto de Europa y América, como es el Instituto del Patrimonio Histórico Español, el Museo del Prado, el Museo de arte ThyssenBornemisza, el Museo Nacional Centro de Arte Reina Sofía (MNCARS), el Centro de Restauración de la Diputación de Álava, el Museo de Bellas Artes de Bilbao... entre muchos $\operatorname{otros}^{332}$.

Años más tarde (1980-1990), con el denominado Plan de renovación de museos, se produjeron grandes mejoras en las instalaciones y servicios de numerosas instituciones. Entre los cambios que se llevaron a cabo destacan: la restauración de edificios históricos donde se ubicaban los museos, actuaciones arquitectónicas parciales, la dotación de recursos para la conservación de las colecciones y la mejora de las instalaciones expositivas (programas gráficos, de señalización e identificación de las piezas) ${ }^{333}$.

El Museo de Bellas Artes de Málaga, el Museo de Bellas Artes de Sevilla, el Museo de Artes y Costumbres Populares de la misma ciudad, el Museo Arqueológico de Málaga, el Museo de la Alhambra, el Museo de Cádiz y el Museo Arqueológico de Cástulo (Linares), son algunos de los centros de Andalucía que se vieron beneficiados con estas inversiones ${ }^{334}$.

En determinados museos el área de conservaciónrestauración está formada a su vez de diferentes

332 SEDANO ESPIN, Pilar. "La conservación de las Obras de Arte en los museos. Funciones del departamento de restauración". En ARBOR, Tomo CLXIV, $N^{\circ}$ 645, Septiembre de 1999. p. 4.

333 VILLAFRANCA JIMÉNEZ, María del Mar. Idem.

334 Idem. p. 36. 
Departamentos interrelacionados entre sí debido a la variedad de materiales que compone la colección del centro. Algunos de ellos podrían ser el Departamento de documento gráfico (manuscritos, libros, cartografía...), de Bellas Artes (pintura, escultura, fotografía...) o de arqueología (cerámica, piedra...).

Por tanto, vemos que a lo largo de los años se han producido transformaciones y cambios en los museos reflejándose en el estado actual de los Departamentos de Conservación-Restauración de los museos españoles.

\section{FUNCIONES}

Según el Real Decreto 620/1987 del 10 de abril, por el que se aprueba el Reglamento de Museos de titularidad estatal y del Sistema Español de Museos, en su artículo 18:

El área de conservación e investigación abarcará las funciones de identificación, control científico, preservación y tratamiento de los fondos del museo y de seguimiento de la acción cultural del mismo.

Se encuadran en esta área las actividades tendentes a:

- La elaboración de los instrumentos de
descripción precisos para el análisis
científico de los fondos.
El examen técnico y analítico
correspondiente a los programas de




preservación, rehabilitación y
restauración pertinentes.
La elaboración y ejecución de programas
de investigación en el ámbito de la
especialidad del museo.
La redacción de las publicaciones
científicas y divulgativas del museo ${ }^{335}$.

Para los Departamentos Técnicos de Conservación de los museos estatales se les encomiendan las siguientes funciones:

- Procurar las condiciones necesarias para la conservación preventiva de los fondos museográficos, tanto en almacenes como en salas de exposición y en talleres de restauración.

- Vigilar y controlar el estado físico de los fondos en almacenes o salas de exposición, así como en todo lo relativo a sus movimientos de cualquier índole.

- Programar y realizar los análisis y exámenes necesarios para el conocimiento del estado de conservación de los fondos $y$ desarrollar las necesarias tareas de preservación, limpieza y restauración.

- Informar sobre la conveniencia de préstamos temporales o depósitos de fondos museográficos en función de su estado de conservación y

335 Real Decreto 620/1987 del 10 de abril, por el que se aprueba el Reglamento de Museos de titularidad estatal y del Sistema Español de Museos. Capítulo VI (Dirección y áreas básicas), artículo 18, Conservación e investigación. 


\footnotetext{
proponer las condiciones físicas para su

traslado y mantenimiento fuera del museo.

- Organizar los sistemas de almacenaje de fondos museográficos de forma que todas las colecciones se encuentren ordenadas, accesibles $y$ en las condiciones adecuadas para su conservación y estudio.

- Gestionar los movimientos de los fondos dentro y fuera del museo.

- Colaborar en programas de investigación de instituciones ajenas al museo ${ }^{336}$.

Por tanto, vemos que la función más importante del Departamento es la de controlar, vigilar y revisar el estado de conservación de su colección.
}

\section{LOCALIZACIÓN Y ESTRUCTURA}

Al igual que ocurrió en la mayoría de los museos internacionales, en España se comenzó trabajando en espacios pequeños, situados en los sótanos del museo y sin posibilidad de cambiar de ubicación ni ampliarse. Unas condiciones y circunstancias muy deficientes que no permiten un trabajo apropiado.

Gracias a las acciones y ayudas que se realizaron en los museos, éstos pudieron mejorar en sus servicios e

336 Conservación en los Museos. Ministerio de Cultura Español. http://www.mcu.es/museos/CE/Funciones/Conservacion/Introduccion.ht ml (consultado el 10 de septiembre de 2010). 
instalaciones. Así, el Departamento de Conservación se traslada a las plantas superiores del edificio mejorando las condiciones de trabajo.

Dentro de estas mejoras podemos reseñar el Departamento de Conservación-Restauración del Museo Nacional del Prado que se ubica en dos salas de la cuarta y quinta planta unidas por un acceso interior, con luz natural, ventilación y salidas para productos tóxicos ${ }^{337}$. Mas las nuevas dependencias dedicadas a talleres de restauración de la reciente ampliación del museo por el arquitecto Rafael Moneo en el claustro de los Jerónimos ${ }^{338}$.

En cuanto a la estructura y organización, suele ser de la misma forma en la mayor parte de los museos de España, sobre todo a partir de los años noventa.

Lo que se intenta es adaptar el espacio, dependiendo del caso, a las distintas secciones del Departamento (laboratorio, talleres, administración, biblioteca...). Es decir, situar las distintas secciones y áreas existentes en el mismo Departamento lo más cerca posible unas de las otras, facilitando la relación y la colaboración entre los operarios de cada uno de ellos. Igualmente, se ubican lo más próximo posible a las zonas de almacenaje y salas de exposiciones y con accesos directos a las mismas.

\section{LABORATORIO Y/O TALLERES}

\footnotetext{
337 SEDANO ESPIN, Pilar. Idem. p. 19.

338 Inaugurado en 2007.
} 


\begin{abstract}
Gracias a la Junta para Ampliación de Estudios e Investigaciones Científicas (JAE) y la Residencia de Estudiantes (RE), en la España de finales del siglo XIX y principios del siglo $x x$, surge un interés $y$ una labor investigadora de la ciencia conocida como la Edad de Plata de la ciencia española. Creando innumerables institutos, centros de estudios y laboratorios de investigación por todo el país, promoviendo estudios en casi todas las ramas de la ciencia (historia, arte, geología, botánica, paleontología, zoología, prehistoria, física, química, matemáticas...) y favoreciendo el impulso del desarrollo de la investigación científica ${ }^{339}$.
\end{abstract}

Estas acciones influyeron rápidamente a los museos. Desde el Museo de Ciencias Naturales, se ayudaba a conseguir los objetivos de la Junta pero, al mismo tiempo, el Museo también se beneficiaba de la labor de ésta: en 1924, se recibian por medio de la JAE más de 50 revistas internacionales -Botanical Abstracts, Nature, Genetics, Journal of Experimental Zoology, etc.-, siendo de destacar el hecho de que algunas de ellas se conseguían como intercambio con las publicaciones del Museo ${ }^{340}$.

339 BARONA VILAR, Josep Lluis. "Los laboratorios de la Junta para Ampliación de Estudios e Investigaciones Científicas (J.A.E.) y la Residencia de Estudiantes (1912-1939)". En Asclepio, Revista de historia de la medicina y de la ciencia, Volumen 59, Fascículo 2, 2007 . p. 87.

340 BeRnAl MARTÍNeZ, José Mariano, LÓPEz MARTínez, José Damián. "La Junta para Ampliación de Estudios (JAE) y la enseñanza de la ciencia para todos en España". En Revista de educación, N Extra 1, 2007. p. 227. 
En cuanto a la bibliografía existente sobre este tema, los autores más destacados en España son Elisa Pinilla Pinilla ${ }^{341}$ y Carmelo Fernández Ibáñez ${ }^{342}$.

Actualmente en muchos museos españoles está integrado en el Departamento o área de Conservación-Restauración el Laboratorio de análisis químico, siguiendo la idea desarrollada en el Museo Nacional Centro de Arte Reina Sofía en el año 1990, de incluir la investigación técnica y analítica dentro del Departamento de Restauración ${ }^{343}$.

Además, dependiendo del tipo de museo, están integrados dentro del Departamento de las diferentes áreas o talleres, como pueden ser: restauración de documento gráfico, de

341 PINILLA PINILLA, Elisa. "Los talleres de restauración en los museos. Criterios básicos". En Actas de la Primeras Jornadas del Patrimonio Histórico-Artístico, II, Burgos, 1982. pp. 809-810.

342 FERNÁNDEZ IBÁÑEZ, Carmelo. "Montaje y funciones del laboratorio de conservación y restauración en un Museo de Arqueología". En Cuadernos de Prehistoria y Arqueología. N²3, 1996. pp. 9-36. - "Una nueva experiencia en arqueología de campo. El laboratorio de conservación y restauración de las excavaciones romanas de Julióbriga". En Arqueología, 13, Reinosa, Cantabria, 1986. pp. 185-188.

- "Los laboratorios de conservación en los museos arqueológicos". En Archivos, Bibliotecas y Museos. Décimo Congreso de Estudios Vascos. Pamplona, 1987. pp. 469-472.

- "Organización y funcionamiento del laboratorio de conservación y restauración". En Arqueología y Conservación, Xinzo de Limia, 1993. pp. 117-129.

343 SEDANO ESPIN, Pilar. "El área de restauración. Museo Nacional del Prado. Madrid". En Restauración \& Rehabilitación, N 109, 2008 . p. 52 . 
madera, textil, piedra, escultura, pintura de caballete, jardinería...

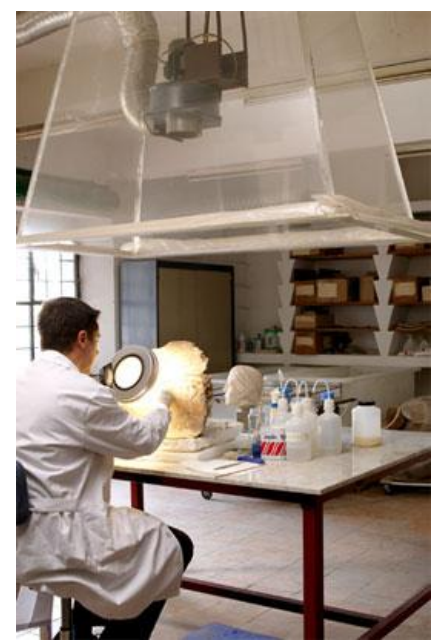

Figura 26. Taller de Restauración de la Piedra. Museo Arqueológico de Sevilla. Junta de Andalucía

En algunos museos se han realizado actividades programadas por el equipo de trabajadores del área de conservación, quienes realizan talleres para que los visitantes puedan presenciar algunas de las tareas de restauración.

En muchas ocasiones es necesario recurrir a instituciones externas al propio museo, como el Instituto de Patrimonio Histórico Español o el Instituto Andaluz de Patrimonio Histórico, para la realización de ciertos análisis y exámenes de piezas por la falta de este instrumental.

Si se realizan en el propio museo los estudios analíticos de las muestras de los diferentes materiales que componen las obras, sería conveniente registrar todos los patrones posibles de tales materiales, con el objetivo de 
disponer de una base de datos que permita realizar estudios tipológicos comparativos y datarlos cronológicamente ${ }^{344}$.

Pero hay que decir que no todos los centros cuentan con un Laboratorio adecuado. Aunque es una inversión algo cara, a la larga resulta rentable para el museo.

Lo que sí está claro es que el Laboratorio de conservación-restauración deberá estar destinado exclusivamente para la función que le dio origen y no funcionar como almacén ${ }^{345}$, como sucede en muchos casos.

Respecto a la seguridad e higiene en el trabajo, Carmen Dávila y Ma Antonia Moreno nos informan que en 1987 el Instituto Nacional de Seguridad e Higiene en el Trabajo elaboró un informe sobre distintos centros con el fin de "informar sobre la posible existencia de riesgo de toxicidad, peligrosidad y excepcional penosidad en los restauradores del Ministerio de Cultura", en el que se detectaron fallos en cuanto a los sistemas de extracción de aire, de iluminación, instalación, eléctrica $y$ de agua... en varios museos de España ${ }^{346}$. Hecho que favoreció y ocasionó una mejora en cuanto a la renovación de los sistemas, instalaciones y servicios de los Laboratorios españoles.

344 Patronato de la Alhambra y Generalife. Consejería de Cultura. http://www.alhambra-patronato.es/ (Consultado el 9 de septiembre de 2010) .

345 FERNÁNDEZ IBÁÑEZ, Carmelo. "Los laboratorios de conservación en los museos arqueológicos". En Archivos, Bibliotecas y Museos. Décimo Congreso de Estudios Vascos. Pamplona, 1987. p. 469.

346 DÁVILA BUITRÓN, Carmen, MORENO CIFUENTES, Ma Antonia. "El laboratorio de restauración del MAN". En ANABAD, Tomo 43, $\mathrm{N}^{\circ} 3-4$, 1993. p. 174 . 
La tarea del Laboratorio en el museo es una más entre las diferentes actividades que se llevan a cabo en el resto de Departamentos y por tanto, deberá disfrutar de una plena libertad de actuación y de criterios compartidos. Igualmente, deberá estudiar e investigar en su propia ciencia, lo que implica una cierta elasticidad en su trabajo diario, que no deberá ser nunca una cadena de producción ${ }^{347}$.

\section{PERSONAL Y SU FORMACIÓN}

La creación de los puestos de restauradores en los museos se producirá a principios del siglo XX cuando se inician las convocatorias de plazas por oposición, por lo que a partir de los años ochenta se irá dando más importancia a la profesión de los conservadores-restauradores.

Diez años más tarde supondrá un cambio realmente importante para éstos, quienes se situarán como Jefes del Departamento de Conservación-Restauración de los museos, hecho que no había sucedido hasta entonces ${ }^{348}$.

Así, la organización de los Departamentos de la mayoría de los museos españoles será prácticamente similar dependiendo del tipo de institución-, siguiendo el esquema del Museo Nacional del Prado (Madrid):

Del Jefe del Área de Restauración dependen los Jefes de Servicio. Uno para Restauración, que supervisa lo que se hace en Pintura, Escultura,

347 FERNÁNDEZ IBÁÑEZ, Carmelo. Idem. p. 471.

348 SEDANO ESPIN, Pilar. Idem. p. 64. 


\begin{abstract}
Marcos, Artes Decorativas, Papel y Soportes; otro para el Gabinete Técnico, que es el que dirige entre otros los estudios radiográficos o reflectográficos. Y después, el Jefe del Laboratorio, que es el que lleva todo lo que implica estudios químicos y biológicos ${ }^{349}$.
\end{abstract}

Pilar Sedano manifiesta que en los últimos años los Jefes de los Departamentos de Conservación-Restauración son restauradores, como en la Pinacoteca de Munich, el Centro Georges Pompidou de París, el Museo de Bellas Artes de Bilbao, el Museo Nacional Centro de Arte Reina Sofía o el Museo Thyssen-Bornemisza de Madrid ${ }^{350}$.

En los casos en el que el museo no dispone de suficientes operarios para realizar los tratamientos de intervención en las piezas, se recurre a personal eventual o becarios del INEM (Instituto Nacional de Empleo) para ayudar a los trabajos de restauración que no puedan llevarlo a cabo solamente la plantilla fija del centro.

\title{
Según Fernández Ibáñez:
}

El conservador-restaurador Es el único que puede llevar a buen término las tareas propias de su profesión, si bien es claro que debemos tener en cuenta que el conservador es un ser humano y no un "mago", con cuyos resultados pueda incluso especularse. Su misión es la de mantener al objeto

\footnotetext{
349 Ibídem.

350 SEDANO ESPIN, Pilar. "La conservación de las Obras de Arte en los museos. Funciones del departamento de restauración". En ARBOR, Tomo CLXIV, $\mathrm{N}^{\circ}$ 645, Septiembre de 1999. p. 18.
} 


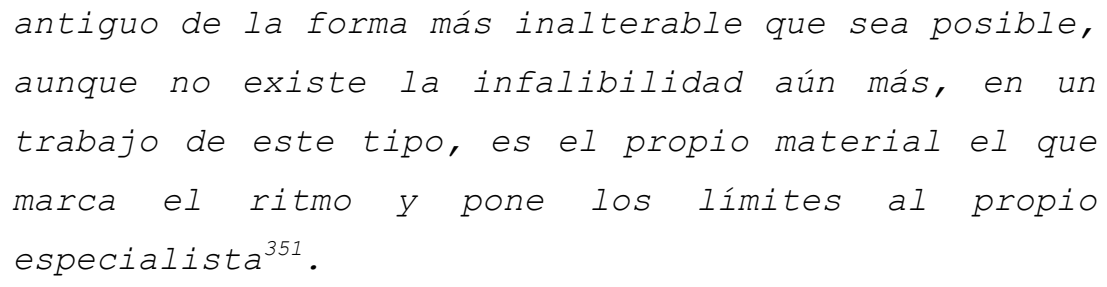

Igualmente, dentro de las funciones del Departamento es imprescindible la formación de los recursos humanos a través de prácticas profesionales y becas de investigación para la realización de trabajos que estudien y amplíen los conocimientos en el campo de la conservación y restauración.

\section{BIBLIOTECA}

Las bibliotecas de los museos tienen su origen en el siglo XVIII con la creación de los primeros grandes museos públicos en Europa. Así, surgen de la propia actividad que se venían desarrollando en el museo, de sus labores de documentación e investigación ${ }^{352}$.

Más tarde, el desarrollo y creación de nuevos museos en el siglo XX marcará la consolidación y desarrollo de las bibliotecas dentro de estas instituciones.

Con lo que respecta a España, las primeras bibliotecas de museos van apareciendo a lo largo del siglo XIX. Entre ellas destacan las bibliotecas del Museo del Ejército (1803), del Museo del Prado (1818), del Museo Arqueológico Nacional

351 FERNÁNDEZ IBÁÑEZ, Carmelo. Ibídem. p. 470.

352 INSÚA LACABE, Eugenia. "Las colecciones de las Bibliotecas de los Museos Estatales". En LIBER 2008, Mesa redonda sobre bibliotecas especializadas y la gestión de sus colecciones. Barcelona, 9 de octubre de 2008 . 
(1867) $\bigcirc$ del Museo Nacional de Reproducciones Artísticas $(1877)^{353}$.

Según la Ley del Patrimonio Histórico Español, las bibliotecas son:

Instituciones culturales donde se conservan,
reúnen, seleccionan, inventarían, catalogan,
clasifican y difunden conjuntos o colecciones de
libros, manuscritos y otros materiales
bibliográficos o reproducidos por cualquier medio
para su lectura en sala pública o mediante préstamo
temporal, al servicio de la educación, la
investigación, la cultura y la información ${ }^{354}$.

El Real Decreto de 29 de noviembre de 1991, en el que se aprueba el Reglamento para el régimen de los Museos Arqueológicos del Estado servidos por el Cuerpo Facultativo de Archiveros, Bibliotecarios y Arqueólogos, en sus artículos 26, 27 y 28 se refiere de esta manera a las bibliotecas del museo ${ }^{355}$ :

- Artículo 26. Los Museos tendrán para su uso particular una biblioteca o colección de libros propios de la especialidad a que sus estudios se dirigen; $y$ en tanto en cuanto los recursos de sus

\footnotetext{
353 Ibídem.

354 Ley 16/1985, de 25 de junio, del Patrimonio Histórico Español. Título VII. Capítulo II (De los archivos, bibliotecas y museos), artículo 59, apartado 2 .

355 LÓPEZ DE PRADO, María del Rosario. "Bibliotecas de museos en España: características específicas y análisis DAFO". En Revista general de Información y Documentación, Vol. 13, N 1, 2003. p. 12.
} 
consignaciones lo permitan, y cuando su importancia lo requiera, estará al frente de la biblioteca un empleado facultativo de los adscritos al establecimiento, designado por el jefe del museo, y sin perjuicio de que se ocupe de otros servicios a los que el Jefe lo destine.

- Artículo 27. Estas Bibliotecas, a pesar de su carácter particular, podrán ser utilizadas por el público, previa autorización especial del jefe del establecimiento.

- Artículo 28. Es cuanto se refiere a la organización facultativa. Lectura pública, régimen, etc., de la Biblioteca, el Bibliotecario se atendrá a lo preceptuado en el Reglamento de Bibliotecas públicas del Estado ${ }^{356}$.

Como afirma María del Rosario López de Prado, actual directora técnica de la Biblioteca Nacional de Madrid ${ }^{357}$, las Bibliotecas de Museos son instituciones muy desconocidas, incluso entre los profesionales de la Biblioteconomía ${ }^{358}$.

Normalmente existe poca información sobre la existencia de bibliotecas en los museos y más aún sobre las colecciones bibliográficas especializadas que albergan.

356 Real Decreto de 29 de noviembre de 1901 aprobando el Reglamento General de los Museos regidos por el Cuerpo Facultativo de Archiveros, Bibliotecarios y Arqueólogos.

357 Presidenta del SEDIC (Asociación Española de Documentación e Información) y Jefa del Servicio de Documentación en la Filmoteca Española.

358 LÓPEZ DE PRADO, María del Rosario. Idem. p. 5. 
El acceso a la información de todo el personal, tanto externo como interno a la propia institución, es algo fundamental.

De esta manera es importante que el museo informe a la sociedad sobre los trabajos de investigación que están llevando a cabo y por ello el investigador debe tener la posibilidad de acceder al estudio y contemplación de los fondos museísticos, así como la consulta de todos los catálogos, tal y como afirma el artículo 23 del Reglamento de los Museos de titularidad estatal y el Sistema Español de Museos -Real Decreto 620/87 del 10 de abril- ${ }^{359}$.

Como consecuencia del avance de la tecnología es posible la difusión y consulta a distancia de los fondos de la biblioteca a través de la página Web del propio museo.

Esta nueva forma de consulta a través del ciberespacio se ha venido denominando de diversas maneras: bibliotecas sin paredes, bibliotecas sin papeles, electrónicas, digitales, virtuales, híbridas... Tienen su desarrollo en la década de los noventa, de manera paralela al desarrollo del documento digital y a la implantación de Internet en estas instituciones ${ }^{360}$.

Los documentos electrónicos son un hecho de la realidad actual que ha sustituido a la biblioteca tradicional y nos

359 PREGO DE LIS, María. "El papel de la biblioteca en el museo". En Museo, $\mathrm{N}^{\circ}$ 2, 1997. p. 233.

360 RODRÍgUez BRAVO, Blanca y SANTOS DE PAZ, Lourdes. "Del documento digital a la biblioteca virtual". En Scire, vol. 8, $\mathrm{N}^{\circ}$ 2, 2002 . pp. $45-46$. 
ofrece una mayor comodidad y accesibilidad a la información para el usuario.

Para que este tipo de bibliotecas funcione con normalidad y esté actualizada, será necesario un mantenimiento continuo de la misma, además de crear un orden coherente de todos los documentos para que la búsqueda sea lo más sencilla y rápida para el lector.

Muchos museos españoles están llevando a cabo proyectos para mejorar las necesidades de los usuarios. Un ejemplo es la biblioteca del Museo Arqueológico Nacional (MAN) de Madrid. Con el proyecto DIDO se agiliza el acceso a los fondos -a través de Internet o en CD-ROM- y se facilita la información de texto completo, in situ o de forma remota ${ }^{361}$.

Otro proyecto a destacar es BIMUS (Red de Bibliotecas de Museos Estatales), el cual se encarga de mejorar la informatización de las colecciones de las bibliotecas de los dieciocho ${ }^{362}$ centros pertenecientes al Ministerio de Cultura español ${ }^{363}$.

361 LÓPEZ DE PRADO, María del rosario. "DIDO: Proyecto para la digitalización de documentos en la Biblioteca del Museo Arqueológico Nacional". En ANABAD, Tomo 43, $\mathrm{N}^{\circ}$ 3-4, 1999. p. 499-500.

362 Pertenecen a BIFUS: la biblioteca del Museo Nacional del Teatro, dependiente del Instituto Nacional de las Artes Escénicas y de la Música (INAEM), y las diecisiete bibliotecas pertenecientes a los museos de titularidad estatal y gestión directa del Ministerio de Cultura a través de la Dirección General de Bellas Artes y Bienes Culturales.

363 BIMUS. Red de Bibliotecas de Museos. Ministerio de Cultura. Gobierno de España. http://www.mcu.es/museos/MC/BIMUS/index.htmI (consultado el 22 de septiembre de 2010). 
Tiene su origen en el Plan de Museos Estatales (20042008) de la Subdirección General de Museos Estatales y su objetivo principal es conseguir un cambio en los procesos de trabajo, fomentando la cooperación a través del uso de herramientas como el Catálogo Colectivo, y desarrollando políticas y servicios bibliotecarios comunes, como la adquisición cooperativa o el préstamo interbibliotecario ${ }^{364}$.

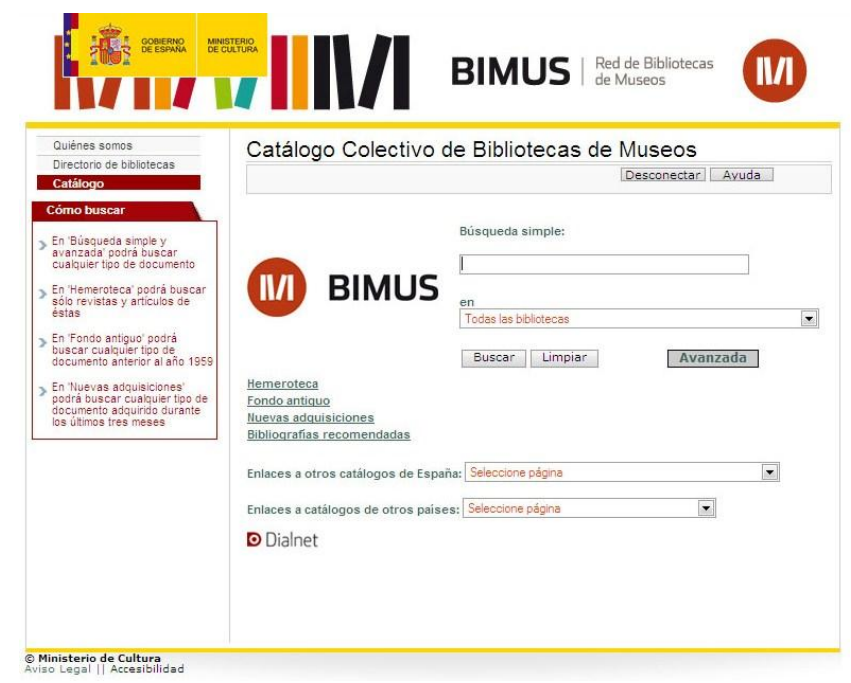

Figura 27. BIMUS, Catálogo Colectivo de Bibliotecas de Museos. Ministerio de Cultura

Además, esta nueva herramienta, que está disponible para los investigadores y público en general, permitirá unificar las colecciones de las bibliotecas de estos museos, adquirir nuevos fondos, racionalizar su utilización y obtener un mayor rendimiento del personal disponible, así como acceder a circuitos internacionales de información y disponer de una imagen corporativa ${ }^{365}$.

\footnotetext{
364 Ibídem.

365 INSÚA LACABE, Eugenia. Idem.
} 


\subsection{EL CONSERVADOR-RESTAURADOR}

Estamos en el tiempo de la restauración de todas las cosas

Hechos $3: 21$.

Hacemos un breve recorrido por la historia y evolución del conservador-restaurador de museos, las funciones principales que desempeña dentro de la institución, así como la formación que ha tenido a lo largo de los años y su código ético. Concluiremos haciendo referencia a este perfil profesional en España.

\section{HISTORIA}

La conservación y restauración de Bienes Culturales es una profesión que va modificando sus características con el paso de los años y está marcada por las características formativas y laborales de cada país. Así, la figura del conservador-restaurador no existía tiempo atrás, como nosotros la conocemos en la actualidad, sino que se consideraban dos profesiones diferentes que con el tiempo llegaron a aunarse.

Es en la Antigüedad clásica -Grecia y Roma- donde encontramos los antecedentes del perfil de restaurador como la persona encargada de la limpieza y las reparaciones generales de los objetos. Los barnices -resina en aguafuerte- 
eran aplicados sobre la obra, en capa fina, para proteger al cuadro del polvo y la suciedad. Para impedir las posibles deformaciones de las tablas, evitaban construirlas en sistemas rígidos, siendo unidas por pernos insertados. La técnica pictórica encáustica consistía en aplicar sobre el soporte una mezcla de cera fundida y color que además de producir una superficie brillante, servía para conservar las pinturas del sol, la sal y el viento ${ }^{366}$.

Durante la Edad Media, pocos datos encontramos referentes a la posible figura del restaurador, pero tenemos noticias documentales de un tal Lamberto, quien restauró la figura de una Virgen incendiada ${ }^{367}$.

Más tarde, la figura del conservador se consideró como el Anticuario o el guardián de la colección de la que estaba a cargo, pasando con el paso de los años a denominarse Arqueólogo. Su tarea consistía en buscar nuevas adquisiciones, investigar, conservar, divulgar, enseñar el conocimiento y exponer.

Ya en el Renacimiento el perfil del restaurador está ligado a la del artista, quien se encarga de asegurar la conservación y mantenimiento de sus propias obras. De esta manera, los primeros restauradores eran los mismos pintores de cámara vinculados a las colecciones reales, careciendo, en un principio, de criterios de intervención comunes. Con el

366 MACARRÓN MIGUEL, Ana María. La conservación y restauración en el siglo XX. Madrid. Tecnos, 2004. pp. 24-25.

367 RUIZ DE LACANAL RUIZ-MATEOS, María Dolores. "El Conservadorrestaurador: el eje de la historia de una profesión". En X Congreso de Conservación de Bienes Culturales, 29-30 de septiembre, 1-2 de octubre de 1994, Cuenca. p. 105. 
paso del tiempo se producirá una separación entre estos dos perfiles, el restaurador y el artista.

Igualmente, la función del conservador de la colección está presente en la época renacentista, tratándose del experto conocedor del arte de la antigüedad, muy unido a su perfil con el artista y restaurador ${ }^{368}$.

Por tanto, en el siglo XVI ya existen tres figuras relacionadas con el mantenimiento y custodia de las obras e inmuebles: el conservador de la colección, el conservador de la ciudad o superintendente y la figura del restaurador asociada al artista ${ }^{369}$.

El paso del restaurador de monumentos, a restaurador del Patrimonio, especializado y enclavado en los museos, se produce de manera paralela a la sustitución del criterio de antigüedad por el valor histórico-artístico y arqueológico ${ }^{370}$.

A caballo entre el siglo XVIII y XIX, es cuando comienza la profesionalización del restaurador apareciendo los primeros profesionales en el ámbito público. Cambia de lugar de trabajo, del taller de pintura pasa al laboratorio de la colección del museo ${ }^{371}$. Concretamente en Venecia surge el Taller de Pintura Pública donde aparece, con ello, un nuevo perfil del restaurador profesional.

\footnotetext{
368 RUIZ DE LACANAL RUIZ-MATEOS, María Dolores. El conservadorrestaurador de bienes culturales: historia de la profesión. Madrid, 1999. p. 34 .

369 Idem. p. 35.

370 Idem. p. 205.

371 Idem. p. 112 .
} 
De esta manera, algunos restauradores se hacen muy populares en Europa, siendo Bartolomeo Cavaceppi ${ }^{372}$ el más famoso de esta época. Momento en el que además se crea la Asociación de Restauradores y aparece la figura del arqueólogo.

A principios del siglo XIX surge la necesidad y el interés de formar a estos profesionales, comenzando a estudiar la opción de crear y abrir escuelas de restauradores. De esta nueva etapa de formación surgen grandes personajes que fueron destacados conservadores de museos como Wilhelm Von Bode y Alfred H. Barr $^{374}$. Pero hay que destacar que hasta finales del siglo XX el perfil profesional del conservador-restaurador no se hará una realidad.

A partir de 1945, fecha en que concluye la II Guerra Mundial, se aprecia un notable crecimiento en las plantillas de los museos. Aunque el número de profesionales por estas fechas es muy limitado y con un reducido horario laboral.

Casi treinta años después, en 1973, se crea el Cuerpo Facultativo de Conservadores de Museos, un hecho fundamental para crear a un nuevo profesional. Imponiéndose, años más tarde, el acceso al mismo a cualquier licenciado superior ${ }^{375}$.

\footnotetext{
372 Escultor y restaurador italiano (1716-1799).

373 Historiador del arte, creador y primer conservador del Museo Kaiser Friedrich de Berlín -actual Museo Bode- (1845-1929). 374 Primer director del Museo de Arte Moderno de Nueva York (19021981).

375 RUIZ DE LACANAL RUIZ-MATEOS, María Dolores. "El conservador de museos en la primera mitad del siglo XX: conservadores de
} 
En 1965 se asocian la Comisión del ICOM para el tratamiento de Pinturas -llamado posteriormente Subcomisión para la Atención de Cuadros- con el Comité del ICOM de laboratorio de Museos, formando el Comité Internacional de Conservación (ICOM-CC) en el que se incluyen a los restauradores, químicos e historiadores en la actividad de tutela del Patrimonio.

Según María Dolores Ruiz, podemos afirmar la evolución de esta figura de la siguiente manera:

El conservador de la colección real, el conservador de la colección pública dependiente de la administración real, el cargo honorario detentado por personalidades del mérito y el cargo de conserje con funciones museográficas, la dirección facultativa o el Conservador de Monumento al frente de los mismos; y posteriormente el conservador nacido a partir de la regulación de la sección de Anticuarios, el Cuerpo Facultativo de Archiveros, Bibliotecarios y Arqueólogos hasta llegar al Cuerpo Facultativo de conservadores de Museos ${ }^{376}$.

Respecto a las funciones de este profesional, en todo museo debe haber, por lo menos, un encargado de la conservación de la colección de la institución. Éste debería ser el conservador-restaurador, ya que es la persona que más conocimientos posee sobre los agentes de deterioro y

monumentos, jefes y directores, anticuarios y arqueólogos". En ANABAD, Tomo 45, $\mathrm{N}^{\circ}$ 2, 1995. p. 128.

376 Idem. p. 120. 
tratamientos de intervención de las piezas. Aunque, como ya sabemos, esta responsabilidad recae sobre todo el personal del centro.

Los conservadores-restauradores han tenido -y siguen teniendo- un papel muy importante en nuestra sociedad, ya que gracias a ellos se ha podido conservar, y por tanto disfrutar, de un Patrimonio que hubiera desaparecido con el paso del tiempo.

Durante muchos años se consideró al restaurador como un artesano que poseía grandes habilidades manuales y que solamente sabía realizar limpiezas en los objetos otorgándole de nuevo su aspecto anterior. Lo que provocó que surgieran polémicas en cuanto a las funciones y características de este profesional.

Igualmente, se creía que la función del conservadorrestaurador consistía únicamente en prestar atención al estado de la colección del museo. Pero es cierto que el conservador-restaurador ha tenido varias funciones $y$ actividades dentro de la institución. Solía ser el receptor y localizador de obras de arte, colecciones privadas y restos arqueológicos, el encargado del inventario, catalogación, registro y clasificación de la colección, el director del museo -en muchos casos-, además de ejercer otras tareas necesarias para el centro pero menos adecuadas a su cargo ${ }^{377}$.

Según Ricardo Olmos, esto se debe -en muchos casos- a no estar correctamente reglamentadas las funciones de este

377 BARRACA DE RAMOS, Pilar. "Algunos aspectos de la documentación en los Museos". En ANABAB, Tomo 44, $\mathrm{N}^{\circ} 1,1994$. 
profesional y a no estar regulada democráticamente la estructura y dinámica interna de los museos ${ }^{378}$.

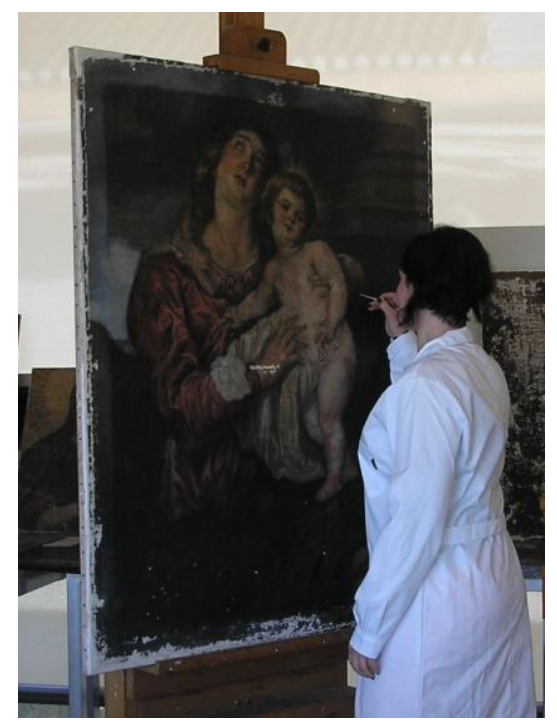

Figura 28. Reintegrando cromáticamente una pintura sobre lienzo Foto de la autora

Un documento muy importante para entender esta actividad es el creado por el Comité de Conservación del Consejo Internacional de Museos (ICOM) en 1984, El conservador-restaurador: una definición de la profesión ${ }^{379}$. Un texto donde se recogen una serie de características, objetivos y necesidades que definen al conservadorrestaurador actual.

Años más tarde se realizaron diferentes congresos y reuniones internacionales que han ampliado y modificado este

\footnotetext{
378 OLMOS ROMERO, Ricardo. "La investigación (de la cultura material) en los museos: notas para un debate". En ANABAD, Tomo 38, $\mathrm{N}^{\circ} 3$, 1988. p. 104.

379 Conocido como la Carta de Copenhague.
} 
documento con nuevas ideas, como es la Guía Profesional ${ }^{380}$, un texto donde se reflexiona sobre el papel del Conservadorrestaurador, su formación y ética.

De esta manera, podríamos concretar el perfil del conservador-restaurador como:

- Una persona que debe tener cierta sensibilidad plástica y una gran habilidad técnica y manual.

- Paciencia.

- Capacidad de organización, concentración, adaptación, coordinación, gestión, planificación y análisis.

- Poseer una buena formación profesional y conocer los criterios de intervención actuales.

- Estar familiarizado y conocer los avances en nuevas tecnologías, así como la creación de nuevos materiales, herramientas y métodos de trabajo.

De entre todas las definiciones que se le han asignado a la figura del conservador-restaurador, es la de Karten Schubert la que mejor expresa la actividad de este profesional,

(...) es quien garantiza la autenticidad de la voz del artista, hace posibles las ambiciones culturales del político, fomenta el museo y su colección solicitando donaciones, vende al patrocinador derechos de acceso sin comprometer la autonomía institucional e interpreta las necesidades

380 La primera y segunda parte fue adoptada en Bruselas en 1993 y la tercera en septiembre de 1994. 
educativas del público y sus deseos de entretenerse. Diplomático, científico, educador, experto en finanzas, esbirro y showman. No hay muchas profesiones que requieran tal diversidad de capacidades y tan alto grado de especialización ${ }^{381}$.

\section{FORMACIÓN}

Una buena formación es esencial a la hora de preparar a un profesional para que sea eficiente en el trabajo y en la vida.

Ya en el siglo XVII, los propios talleres de restauración se utilizaban como lugares de formación para los artesanos, continuándose hasta el siglo XIX. Pero la verdadera necesidad de formar a los restauradores comienza a partir de 1819, año en el que Pietro Edwars ${ }^{382}$ escribe un documento para una escuela de restauración de pintura, Progetto per una scuola di restauro della pittura, aconsejando sobre la necesidad de la preparación de los restauradores ${ }^{383}$.

A partir de entonces los profesionales en conservación y restauración comienzan a instruirse en centros de formación

\footnotetext{
381 SChUBERT, Karsten. El Museo. Historia de una idea. Desde la Revolución Francesa a hoy. Granada. Turpiana, 2008. p. 106. 382 Restaurador italiano (1744-1821). 383 SEDANO ESPIN, Pilar. "La conservación de las obras de arte en los museos. Funciones del departamento de restauración". En ARBOR, Tomo CLXIV, $N^{\circ}$ 645, Septiembre de 1999. p. 2.
} 
estatal, al igual que se enuncian las normas que los regulan en el ámbito internacional ${ }^{384}$.

Es importante destacar la actividad que se está desarrollando en el ICOM-ICTOP (International Committee for the Training of Personnel ${ }^{385}$ ) desde su fundación en 1968. El objetivo de este comité es fomentar y promover programas de enseñanza a nivel universitario y a trabajadores de museos en todas las regiones del mundo, además de preparar a estos profesionales -en cooperación con otros comités-, para enfrentarse a los desafíos laborales en el futuro. Se basa en la idea de que la buena formación y enseñanza es la condición previa de buenas prácticas ${ }^{386}$.

De esta manera, el conservador-restaurador ha dejado de ser la persona de antaño, el artesano y dueño de las piezas de la colección, para convertirse en profesional con un alto nivel de formación. Debe poseer una titulación superior, ya que al trabajar y manipular con piezas de un alto valor artístico, histórico y cultural, su responsabilidad resulta muy grande.

Ahora existen especialidades que anteriormente no figuraban en las enseñanzas, como es la conservaciónrestauración de bienes muebles (escultura, pintura, piedra,

384 ESCOHOTADO IBOR, Teresa. "La formación de los restauradoresconservadores de arte contemporáneo, un reto: de la formación tradicional a la actual". En Revista de Museología, No 5, Julio de 1995. p. 25.

385 Comité Internacional para la Formación del Personal.

386 International Committee for the Training of Personnel. http://ictop.alfahosting.org/(consultado el 6 de octubre de 2010). 


\begin{tabular}{l}
\hline madera, retablos, cerámica...) e inmuebles, implicando \\
diferentes objetos realizados con distintos materiales.
\end{tabular}

Como apunta Iñaki Díaz Balerdi"387, "es necesario formar a personas que sean capaces de plantearse como primer dilema el papel del museo en la sociedad y su propio papel como profesionales especializados. Capaces de ir más allá de la resolución de problemas técnicos en el desempeño de su profesión. Capaces de inventar caminos que hagan más viables y más operativos a los museos. Capaces de hacerlos más inteligibles, más cercanos, más abiertos.

Si los museos cambian también deberían cambiar las estrategias formativas, asunto que ya se debate y se seguirá debatiendo en un futuro" ${ }^{388}$.

Así, este profesional debe perfeccionar y ampliar sus conocimientos día a día, además de dar a conocer su trabajo, para que esta profesión esté documentada para el futuro y pueda ser más reconocida y respetada internacionalmente.

\section{EL CÓDIgo ÉTICO}

Los Conservadores-Restauradores de museos poseen su propio código deontológico que analiza su conducta ética en el trabajo a través de unas normas donde aparecen una serie de obligaciones que deben cumplir respecto a los propietarios

387 De conservador del Museo de Bellas Artes de Álava pasó a ser profesor titular de la Universidad del País Vasco.

388 DÍAz BALERDI, Iñaki. "La formación de profesionales de museos. De la mística de la conservación al absolutismo de la gestión". En Revista de Museología, $\mathrm{N}^{\circ}$ 47, 2010. p. 13. 
de las obras o depositario legal, a sus compañeros de trabajo y profesión y su formación.

Según apunta Gary Edson ${ }^{389}$, el objetivo principal de este código ético es la necesidad de mejorar el nivel de la práctica profesional... y reforzar el papel y las responsabilidades del museo con la sociedad ${ }^{390}$.

Uno de los primeros códigos éticos se creó en Estados Unidos en 1925, titulado Código Ético para los trabajadores de Museos.

Posteriormente, en 1982, se redacta en el Museo Real de Ontario (Canadá) un texto titulado Declaración de principios y política sobre ética y conducta, basado en los Códigos de las Asociaciones Canadienses y Americanas de Museos ${ }^{391}$. Un año más tarde se acepta en la Asociación Profesional Nacional (Inglaterra) el documento denominado code of conduct for Museum Curator -Código de conducta para los Conservadores de Museos-, donde se exponen las normas que debe cumplir este profesional en el ámbito laboral.

Por último hay que destacar el Código de Deontología del ICOM aprobado en Buenos Aires (Argentina) en $1986^{392}$ y elaborado a partir de las experiencias de grandes

389 Director ejecutivo del Museo de la Universidad Tecnológica de Texas (Estados Unidos).

390 Citado por Pilar Romero, "La conducta ética entre los profesionales de museos, según algunos códigos internacionales europeos". En Museo, $\mathrm{N}^{\circ}$ 3, 1998. p. 62

391 ROMERO DE TEJADA PICATOSTE, Pilar. "La conducta ética entre los profesionales de museos, según algunos códigos internacionales europeos". En Museo, $\mathrm{N}^{\circ} 3,1998 . \mathrm{p} .63$. 392 Revisado por última vez en 2006. 
Los Departamentos de Conservación-Restauración en los museos andaluces: estudio y análisis de casos

profesionales de la materia. En este texto se aborda de una manera integral las normas de conducta y ejercicio profesional, es decir, los aspectos técnicos, organizativos y responsabilidades del personal del museo. 


\subsubsection{EL CONSERVADOR-RESTAURADOR EN ESPAÑA}

\section{HISTORIA}

En lo que respecta a la historia del conservadorrestaurador español, una de las primeras intervenciones más antiguas que se conocen data de mediados del siglo XVI (15471548). Se trata de la obra pictórica La Virgen de la Antigua de la Catedral de Sevilla intervenida por el pintor de fábrica Antón Pérez ${ }^{393}$.

Un siglo más tarde comenzarán a salir del anonimato gran cantidad de artistas-restauradores. Entre ellos sobresale la figura de Francisco Pacheco ${ }^{394}$, quien escribió el tratado Arte de la pintura, su antigüedad y su grandeza (1649), donde ya expone ideas y cuestiones referentes a las técnicas de restauración siendo de gran ayuda para muchos pintores y restauradores ${ }^{395}$.

Sin embargo, el incendio del Real Alcázar de Madrid de 1734 provocó la desaparición de numerosas obras y piezas de gran valor, hecho que marcó un nuevo camino en la consideración de la figura del restaurador. Se tuvo que

\footnotetext{
393 RUIZ DE LACANAL RUIZ-MATEOS, María Dolores. El conservadorrestaurador de bienes culturales: historia de la profesión. Madrid, 1999. pp. 41-42.

394 Tratadista de arte, pintor y restaurador (1564-1664).

395 RUIZ DE LACANAL RUIZ-MATEOS, María Dolores. "Francisco Pacheco y la Restauración". En Laboratorio de Arte, N 7, 1994. p. 325.
} 
solicitar urgentemente que un artista se dedicara únicamente - por primera vez- a las tareas de restauración de los objetos dañados por las llamas ${ }^{396}$. A partir de este suceso se comenzaron mostrar los primeros signos de reconocimiento de esta labor.

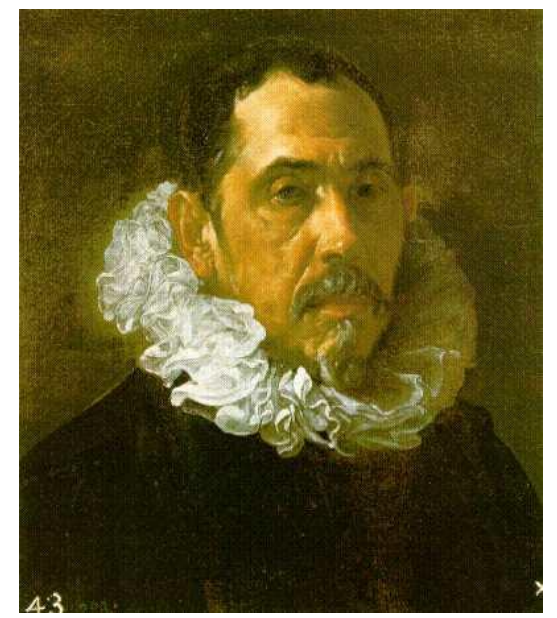

Figura 29. Francisco Pacheco (1619). Museo del Prado (Madrid)

En el siglo XIX, Vicente Poleró escribió el primer tratado español sobre la labor de restauración, titulado El Arte de la Restauración (1855). Posteriormente la creación de Academias y su labor de control trajo consigo los informes de restauración, los primeros documentos oficiales donde aparece definida la figura del restaurador ${ }^{397}$.

A principios del siglo xx ya se contempla la aparición de restauradores en los museos arqueológicos y en los talleres de Restauración de pintura y escultura del Museo del

396 SEDANO ESPÍN, Pilar. "El área de restauración. Museo Nacional del Prado. Madrid". En Restauración \& Rehabilitación, N 109, 2008. p. 50 .

397 RUIZ DE LACANAL RUIZ-MATEOS, María Dolores. Idem. p. 157. 
Prado. Además, se constituye el perfil de restaurador de objetos histórico-artísticos gracias a la creación de la Junta de Conservación y Restauración de pinturas y obras de arte antiguo.

En 1931 comienzan a convocarse las plazas de restaurador en el Museo Arqueológico Nacional de Madrid, quedando expresados en las convocatorias el perfil del restaurador de objetos arqueológicos ${ }^{398}$. Al mismo tiempo, se reglamentan los museos españoles quedando plasmados en los documentos los cambios principales producidos en cuanto a la organización y definición de los perfiles profesionales. Así, el Real Decreto del Ministerio de Instrucción y Bellas Artes, establece el Reglamento para el régimen de los Museos Arqueológicos del Estado de 1901, y el Reglamento para el régimen y funcionamiento del Museo Nacional del Prado, establecido por Real Decreto de 10 de mayo de $1920^{399}$.

En el segundo tercio del mismo siglo se verá frenado este gran auge y el restaurador se encontrará en una complicada situación debido a la escasez y falta de personal -y titulación adecuada- a pesar del incremento de los museos españoles

Pero históricamente será en los años ochenta cuando se empiece a conocer, valorar y reconocer el trabajo y la profesión del conservador-restaurador. Por lo que se comienzan a realizar y organizar diferentes programas y proyectos en colaboración con museos norteamericanos. Destaca el Museo del Prado que gracias al Comité Conjunto Hispano-

\footnotetext{
398 Idem. P. 208.

399 SEDANO ESPÍN, Pilar. Idem. p. 64.
} 
Norteamericano, estudió las colecciones del Greco, Goya y Velázquez existentes en los museos ${ }^{400}$.

Esto, junto con la apertura del Instituto de Conservación y Restauración de Obras y Objetos de Arte, Arqueología y Etnología ${ }^{401}$ (ICCR, 1961), la creación del Ministerio de Cultura (1977) y las Escuelas de Restauración, hicieron que esta profesión cobrara cada vez más importancia y transformara el panorama de los conservadores-restauradores en la sociedad española.

Será a partir de los años noventa cuando se vean por primera vez a los restauradores como Jefes de Departamentos de Restauración en los museos. Un cambio realmente muy importante en el que el restaurador, pasa de estar supeditado a un historiador a llegar a ser el Jefe de un Departamento ${ }^{402}$.

Aunque ya se han comentado las funciones del restaurador con anterioridad -ya que son las mismas a nivel nacional como internacional- comentaremos brevemente el origen y la situación de este perfil en España.

Ya en 1880 Mariano de la Roca y Delgado403 publicó un tratado sobre restauración en España -titulado Compilación de todas las prácticas de la pintura, desde los antiguos griegos

\footnotetext{
400 RUIZ DE LACANAL RUIZ-MATEOS, María Dolores. "El conservador de museos en la primera mitad del siglo XX: conservadores de monumentos, jefes y directores, anticuarios y arqueólogos". En ANABAD, Tomo 45, $\mathrm{N}^{\circ}$ 2, 1995. p. 122.

401 Más tarde denominado Instituto de Conservación y Restauración de Obras de Arte (ICROA).

402 SEDANO ESPÍN, Pilar. Idem. p. 64.

403 Pintor y escritor español (1825-1872).
} 
hasta nuestros días- en el que hace referencia a las técnicas de limpieza, forración y restauración de pinturas al óleo.

Según algunos expertos, cada vez hay más unidad entre los restauradores españoles de la que antes existía. Las reuniones de trabajo, la realización de congresos y seminarios, los proyectos conjuntos y el intercambio de experiencias y conocimientos es cada vez más frecuente entre los conservadores-restauradores. Al trabajar en diferentes instituciones sobre los mismos asuntos -aunque sean líneas de investigación diferentes- es muy enriquecedor compartir los conocimientos de una materia entre diversos profesionales.

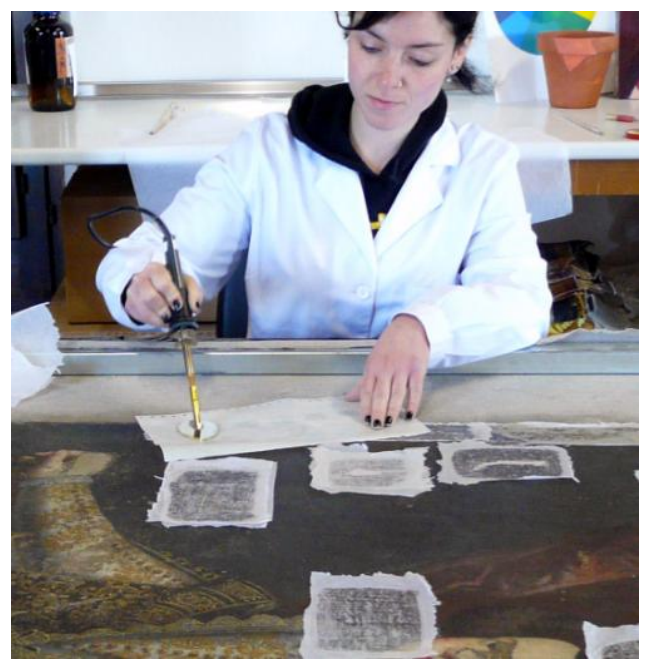

Figura 30. Realizando un sentado de color en una pintura sobre lienzo

Foto de la autora

Como sabemos, cuando llega una obra al museo es el restaurador el que se encarga de plantear los problemas y posibles soluciones al deterioro que la obra presenta, siempre con ayuda del químico y el biólogo. Para ello necesita poseer un conocimiento profundo y detallado de los 
cambios, desperfectos y características de los diferentes Bienes Culturales, y poder plantear las cuestiones necesarias para llevar a cabo la metodología de trabajo más adecuada a cada obra.

De la misma manera, este personal debe investigar en perfeccionar las técnicas de análisis y tratamientos de restauración, así como difundir los datos científicos de las investigaciones que se realicen en laboratorio del museo.

\section{FORMACIÓN}

Hemos visto que a principios del siglo XIX aparece la necesidad y el interés de formar a un personal especializado en la restauración de obras, pero todavía a finales del siglo XIX no se tenía un concepto claro de lo que era ser un restaurador.

A partir de que España cada vez más se va abriendo al exterior y van llegando influencias de otros países, es cuando se va estableciendo poco a poco otro criterio de cómo tiene que ser la formación del restaurador ${ }^{404}$.

Según la opinión de Vicente Poleró y Toledo, el restaurador debía poseer habilidades prácticas como el dominio del dibujo, el color y la composición, además de

404 SEDANO ESPÍN, Pilar. Idem. p. 64. 
tener profundos conocimientos teóricos en Historia del Arte conocer las escuelas y autores de obras- ${ }^{405}$.

En un primer momento la formación especializada técnica de los conservadores-restauradores se adquiere con la experiencia en el propio museo, pero será en la década de los años sesenta del siglo XX cuando se tienda a la formación de escuelas específicas ${ }^{406}$.

En España existen importantes centros y escuelas dedicadas a la Conservación de Bienes Culturales, como es el caso de la Escuela Superior de Conservación y Restauración de Madrid ${ }^{407}$, Galicia, Aragón o Cataluña. Centros que ya incorporan en sus planes de estudio las nuevas disciplinas como son la física, química y biología, además de otras asignaturas referentes a la conservación y restauración.

Pero la transformación de las antiguas Escuelas Superiores de Bellas Artes en Facultades Universitarias (1978) supuso un gran avance para la formación de personal en conservación y restauración de Bienes Culturales, ya que en algunos centros se aprobaron planes de estudios que incluían la especialidad de Restauración. Así, en 1980 se creó la Facultad de Bellas Artes en Madrid, Barcelona, Sevilla,

405 CALVO MANUEL, Ana María. "Tendencias actuales en conservaciónrestauración de pintura". En Actas de los XVI Cursos Monográficos sobre el Patrimonio Histórico. Reinosa, Julio de 2005. p. 166. 406 RUIZ DE LACANAL RUIZ-MATEOS, María Dolores. Idem. p. 131.

407 Es la más antigua de España, remontando sus orígenes a los años sesenta. 
Bilbao y La Laguna (Canarias). Posteriormente se creó en Granada (1988) y en Valencia (1989) ${ }^{408}$.

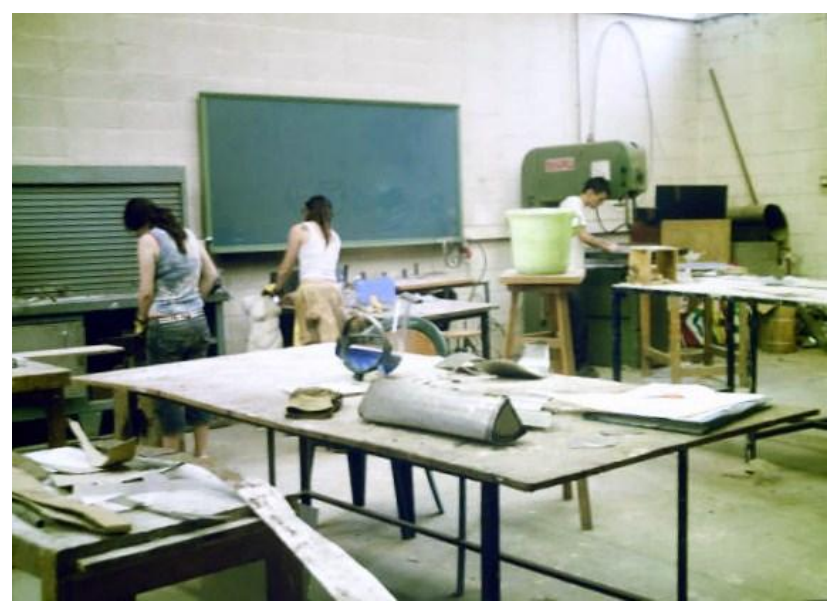

Figura 31. Aula de Escultura de metal de la Facultad de Bellas Artes de Granada

Foto de la autora

Hasta 1985, predominaba la idea de que el acceso a una plaza de Conservador de Museos debía implicar una preparación anterior en el ámbito de la Museología y de la Investigación, por eso las prácticas profesionales previas eran obligatorias a la hora de presentarse a una oposición ${ }^{409}$.

En los museos gestionados por la Consejería de Cultura de la Junta de Andalucía y de titularidad Estatal o autónoma, la primera oferta pública aparece en 1988, en la que se

408 Memoria para la solicitud de verificación del título oficial de graduado o graduada en Conservación y Restauración de Bienes Culturales por la Universidad de Sevilla. Universidad de Sevilla, 2009 .

409 OLMOS ROMERO, Ricardo. "La investigación (de la cultura material) en los museos: notas para un debate". En ANABAD, Tomo 38, $\mathrm{N}^{\circ} 3$, 1988. p. 93 . 
convocan cuatro plazas de Conservadores de Museos y once de Ayudantes de Museos, resolviéndose la convocatoria en 1991. La segunda oferta pública fue en 1992, convocándose únicamente once plazas de Conservadores, realizándose la convocatoria en 1993 y las pruebas selectivas en 1994. Posteriormente, se realizó otra oferta pública en 1996, ofertándose nuevamente cuatro plazas de Conservadores ${ }^{410}$. Posteriormente se han ido ofertando nuevas plazas de Conservadores, ayudantes y auxiliares de museos.

Hay que destacar la gran labor que se está realizando en la Universidad Politécnica de Valencia, especialmente en el Departamento de Conservación y Restauración de Bienes Culturales, ya que están promoviendo una serie de actividades dirigidas a la enseñanza e investigación de los restauradores españoles

Además, esta Universidad dirige el Proyecto Nacional Archivo Histórico de los Restauradores Españoles aprobado por el Ministerio de Educación y Ciencia en el año 2007, con el fin de conocer y documentar, por una parte, la historia de la restauración en España, y por otra, los materiales y técnicas que emplean ${ }^{411}$.

410 LUQUE CEBAlLOS, Isabel, ROMERO MORAgAs, Carlos, tASSARA ANDRAdE, Pilar, PÉREz IRRIARTE, Luz. "El mercado laboral y la formación de los profesionales de los museos en Andalucía". En Revista de Museología, $\mathrm{N}^{\circ}$ 13, 1998. p. 39.

411 "La UPV lidera un proyecto nacional para crear un archivo histórico de restauradores españoles", 18 de enero de 2010. En Qué.es, Periódico de Valencia.

http://www.que.es/valencia/201001181028-upv-lidera-proyecto-

nacional-crear.html (consultado el 4 de octubre de 2010). 
En Andalucía, el programa de formación del Instituto Andaluz del Patrimonio Histórico (IAPH) oferta cursos de especialización teórico-prácticos -de corta duración-, organizados en colaboración con asociaciones y colegios profesionales con el objetivo de perfeccionar a los profesionales en Patrimonio y Gestión Cultural. Las sedes de los cursos se encuentran en las provincias andaluzas de Almería, Cádiz, Granada, Jaén, Málaga y Sevilla ${ }^{412}$.

De la misma manera, son esenciales las actividades que realizan las Asociaciones de Amigos de los Museos, ya que organizan e imparten cursos, conferencias, publicaciones y actividades encaminadas a formar a este personal interesado en el Patrimonio. Sin olvidarnos de los trabajos de investigación y Tesis Doctorales que están realizando investigadores de las Universidades, ya que ayudan a ampliar los conocimientos y analizar el estado actual de la conservación y restauración.

Debido a la importancia de esta profesión para la conservación del Patrimonio, se requiere una formación específica -tanto práctica como teórica- con un alto nivel de especialización, ya que es un trabajo interdisciplinar que requiere el conocimiento de varias ramas científicas.

Actualmente también se recurre a personal eventual del Instituto Nacional de Empleo (INEM) para ayudar a los trabajos de restauración que no pueden realizar solamente la plantilla fija del museo.

412 Instituto Andaluz de Patrimonio Histórico (IAPH). Junta de Andalucía. http://wWw.juntadeandalucia.es/cultura/iaph/nav/index.jsp (consultado el 5 de octubre de 2010). 
La falta de enseñanzas universitarias en conservación y restauración ha sido uno de los problemas a los que se han tenido que enfrentar los museos, creando un cierto desorden y caos en los departamentos a la hora de realizar los contratos a los profesionales.

Con el nuevo plan de estudios -Plan Bolonia413- se ha creado e implantado en España un Grado Universitario de cuatro años en Conservación y Restauración de Bienes Culturales, que permitirá la formación de profesionales de la conservación de nuestro Patrimonio.

Se trata de nuevas titulaciones equivalentes en toda Europa, estructuradas en grado y postgrado, con la intención de impulsar la movilidad de estudiantes y profesionales de la enseñanza, así como de superar los obstáculos para el ejercicio de la profesión. Por tanto, los objetivos básicos de este plan son la obtención de un sistema integrado y comparable en toda Europa, así como la aplicación de una nueva metodología de enseñanza y aprendizaje ${ }^{414}$.

Este título, que deberá atender las recomendaciones de ECCO y ENCORE ${ }^{415}$, además de mejorar la capacitación, servirá

\footnotetext{
413 Nuevo plan de estudios europeo que se inició en 1999.

414 MIRAMBELL ABANCó, Miquel. "El nuevo grado en conservación y Restauración de Bienes Culturales: un reto para la ESCRBCC". En XTEX, Xarxa Telemática Educativa de Catalunya. http://www.xtec.es/centres/a8044961/El nuevo grado.pdf (consultado el 24 de septiembre de 2010).

415 La Confederación Europea de Organizaciones de ConservadorRestauradores y la Red Europea de Educación para la ConservaciónRestauración, http://www.ecco-eu.org/about-e.c.c.o./professionalguidelines.html.
} 


para articular y delimitar los diferentes estadios

formativos, hasta ahora confusos en cuanto a la delimitación de competencias formativas, de forma que también quede garantizada la formación de investigadores que avancen en el estudio de los problemas de conservación que afectan a los Bienes Culturales así como en el diseño y aplicación de nuevos métodos de conservación ${ }^{416}$.

Además, facilitará la realización de programas de cooperación y de intercambio mediante una red europea de instituciones de formación y de investigación en materia de conservación-restauración. Igualmente, se colaborará con otros Centros europeos mediante la participación en proyectos de futuros programas marco ${ }^{417}$.

\footnotetext{
416 Título: Grado en Conservación y Restauración de Bienes Culturales. ANECA, Universidad de Granada, 2009. 417 Ibídem.
} 


\section{PANORAMA DE LOS DEPARTAMENTOS DE CONSERVACIÓN-RESTAURACIÓN EN ANDALUCÍA. RESULTADOS OBTENIDOS DE LAS ENCUESTAS.}

Según los resultados obtenidos de la investigación y como se puede observar en la tabla 3, de ciento sesenta y cuatro (164) museos -de la lista definitiva ${ }^{418}$ - han contestado un total de ochenta y ocho (88) ${ }^{419}$, es decir, se ha obtenido un 53,65\% de respuestas. De éstos; cuarenta y ocho (48) han sido de titularidad pública y cuarenta (40) de titularidad privada. Remitiendo el cuestionario cumplimentado un número de treinta y cuatro (34) instituciones.

\begin{tabular}{|c|c|}
\hline PROVINCIAS Y MUNICIPIOS & $\mathrm{N}^{\circ}$ DE HABITANTES \\
\hline ALMERÍA & $188.810 \quad 84.227$ \\
\hline - El Ejido & 82.665 \\
\hline - Roquetas de Mar & \\
\hline CÁDIZ & 126.766 \\
\hline - Jerez de la Frontera & 267.532 \\
\hline - Algeciras & 116.209 \\
\hline - San Fernando & 96.366 \\
\hline - El Puerto de Santa María & 87.696 \\
\hline & 77.293 \\
\hline & 65.805 \\
\hline
\end{tabular}

\footnotetext{
418 La lista inicial de museos era superior a la definitiva al eliminarse los centros y organismos que no eran declarados como museos, quedando un número total de ciento sesenta y tres (163) museos.

419 Ver Anexo.
} 


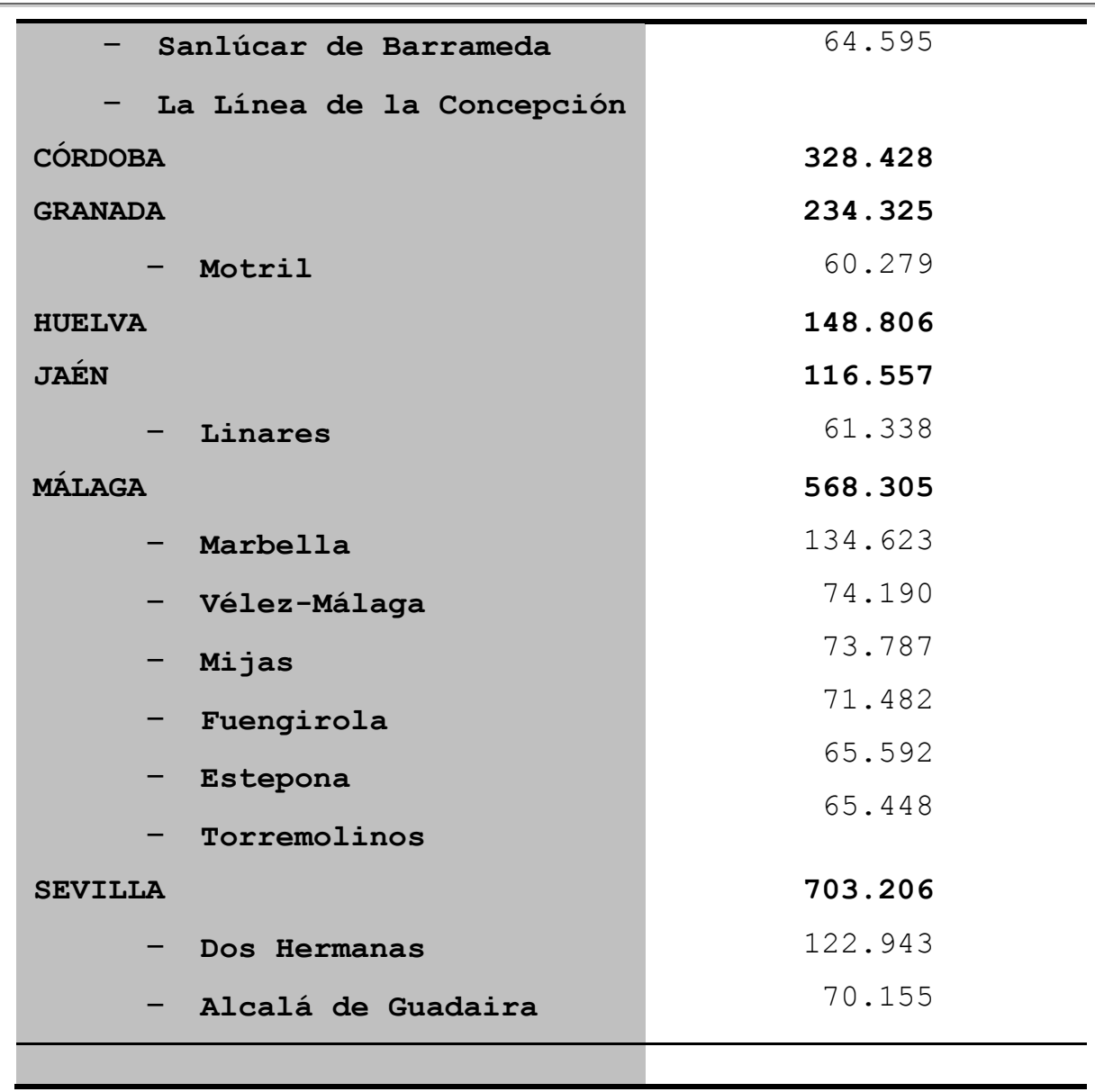

Tabla 1. Número de habitantes por provincias y municipios con más de 60.000 habitantes ${ }^{420}$

\footnotetext{
420 Información obtenida del SIMA (Sistema de información Multiterritorial de Andalucía) según los datos obtenidos del año 2009. Instituto de Estadística de Andalucía. Consejería de Economía y Hacienda.
} 


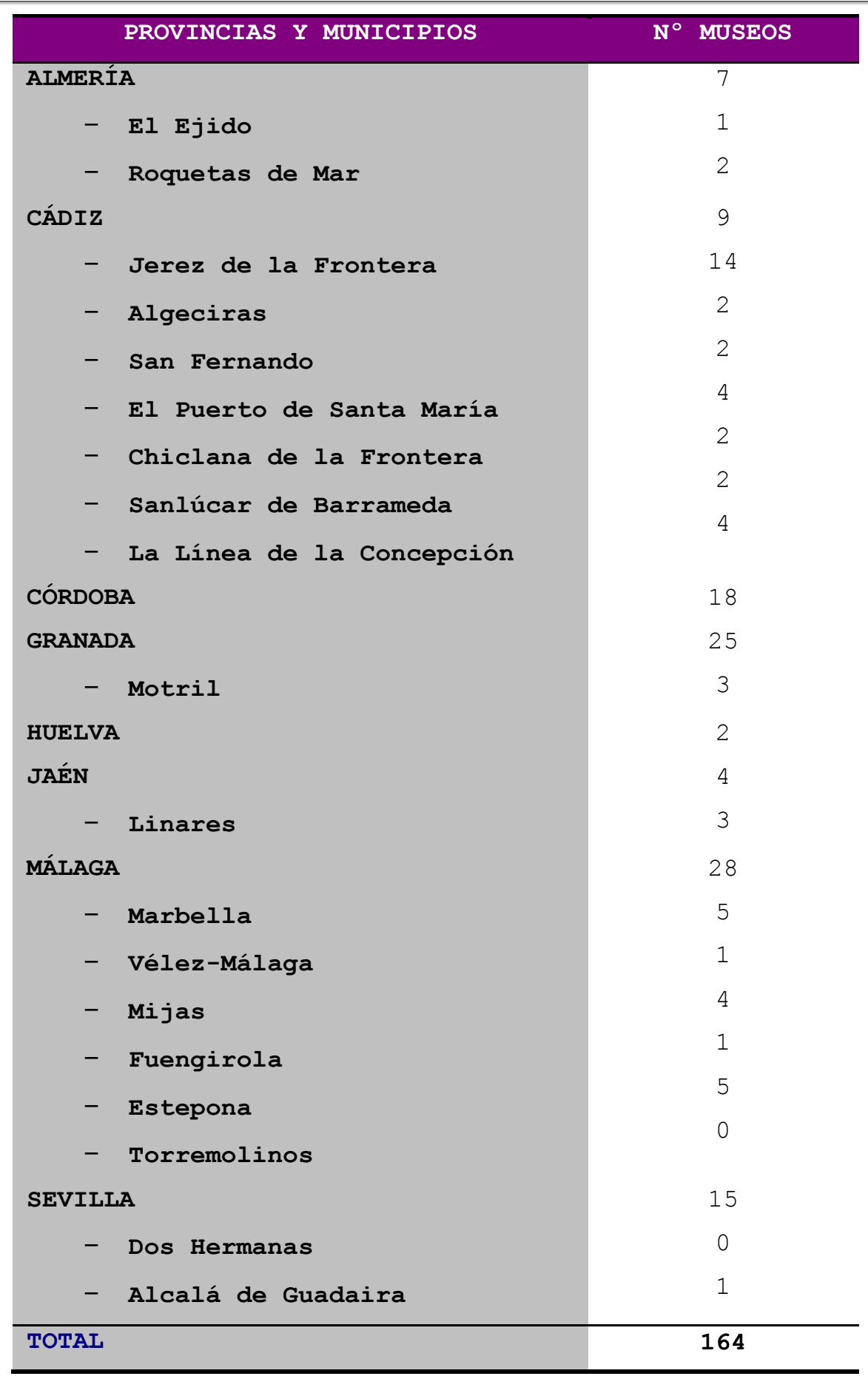

Tabla 2. Número de museos en provincias y municipios andaluces 
Gran cantidad de los museos eclesiásticos y pequeñas instituciones no llegaron a contestar el cuestionario por circunstancias diversas -pocos medios, tanto materiales como económicos, y falta de tiempo-, siendo la más común la no disposición de Departamento, área o taller de ConservaciónRestauración, realizando esta labor los talleres o técnicos externos a la propia institución. Como son -en algunos casos, el conservador municipal, las Asociaciones privadas, el Instituto de Conservación y Restauración de Bienes Culturales de Madrid (ICRBC), el Instituto del Patrimonio Histórico Español (IPHE), el Instituto Andaluz de Patrimonio Histórico (IAPH) -en ocasiones puntuales-, el propio servicio del Excmo. Ayuntamiento -Área de Patrimonio-, la Junta de Andalucía -gracias a sus subvenciones-, o empresas de restauración.

\begin{tabular}{lccccc}
\hline & & & SIN & SIN & SIN \\
PROVINCIAS & MUSEOS & DEPARTAMENTOS & DEPARTAMENTO & CONTESTAR & DATOS \\
\hline ALMERIA & 10 & 1 & 2 & 7 & \\
CÁDIZ & 39 & 9 & 11 & 17 & 2 \\
CÓRDOBA & 18 & 4 & 3 & 7 & 4 \\
GRANADA & 28 & 2 & 12 & 14 & 1 \\
HUELVA & 2 & 1 & - & 3 & 2 \\
JAÉN & 7 & 2 & 2 & 31 & $\mathbf{8}$ \\
MÁLAGA & 44 & 5 & 6 & $\mathbf{8 4}$ & \\
SEVILLA & 16 & 2 & $\mathbf{4 6}$ & & \\
\hline TOTAL & $\mathbf{1 6 4}$ & $\mathbf{2 6}$ & & & \\
\hline
\end{tabular}

Tabla 3. Datos obtenidos de la investigación 
De este modo, habría que decir que no solamente los Departamentos de Conservación-Restauración trabajan para la institución, sino que muchos de ellos ofrecen servicios de restauración a los Ayuntamientos u otras instituciones, siempre bajo unas normas generales para asegurar la conservación de la pieza.

En cambio, como hemos visto, otros museos encargan sus restauraciones a empresas privadas al carecer de medios en la propia institución y de un espacio adecuado para tal acción.

Otro gran número de los museos dejaron sus contestaciones en blanco ya que en muchos de ellos no estaban desarrollando ninguna actividad $\bigcirc$ se encontraban en restauración, reforma o rehabilitación integral del edificio y elaborando el Plan Museológico para una próxima apertura. Otros, por su reciente inauguración, estaban a la espera de documentación, recepción de la colección o de la contratación de una empresa que los gestione, por lo que no pudieron facilitar información a la investigación.

Como dato significativo es de destacar la actitud mostrada en algunas instituciones por su participación y rápida respuesta al cuestionario. En cambio, a la mayoría hubo que remitirles el cuestionario en sucesivas ocasiones.

\section{ANÁLISIS DE LOS RESULTADOS DE LAS ENCUESTAS}

A continuación se analizarán los resultados obtenidos de las encuestas realizadas a los diferentes museos andaluces. 
Los museos que remitieron la encuesta cumplimentada son:

- ALMERÍA

- Museo Arqueológico provincial.

- CÁDIZ

- Museo de Cádiz.

- Conjunto Arqueológico Baelo Claudia.

- La Línea de la Concepción:

- Museo Taurino Municipal.

- Museo del Istmo.

- Museo Cruz Herrera.

- Jerez de la Frontera:

- Museo del Enganche.

- Museo Arqueológico Municipal.

- CÓRDOBA:

- Palacio-Museo de los Marqueses de Viana.

- Museo del Conjunto Monumental de Madinat alZahara.

- Museo de Paleobotánica.

- Museo Arqueológico y Etnológico.

- Museo de Bellas Artes.

- GRANADA

- Museo "Universo Manuel de Falla".

- Museo Parque de las Ciencias.

- Museo de Minerales de la Universidad de Granada.

- Museo Mariana Pineda.

- Museo Etnográfico y Medioambiental Cuevas del Sacromonte.

- Museo de las Ciencias "Padre Suárez".

- Centro José Guerrero. 


\section{- Museo Arqueológico y Etnológico. \\ - Museo de Bellas Artes. \\ - Museo Casa de los tiros de Granada. \\ - Motril: \\ - Museo Preindustrial de la Caña de Azúcar de la Costa Tropical}

- HUELVA:

- Museo de Huelva.

- JAÉN :

- Museo de Jaén.

- Linares:

- Museo Arqueológico de Cástulo.

- MÁLAGA:

- Museo Picasso.

- Museo Casa Natal Fundación Picasso.

- SEVILLA:

- Centro Andaluz de Arte Contemporáneo.

- Museo de la Basílica de la Macarena.

- Museo Arqueológico.

- Museo de Bellas Artes.

- Museo de Artes y Costumbres Populares.

En la siguiente tabla se puede observar el número de instituciones que remitieron tal cuestionario: 


\begin{tabular}{|c|c|}
\hline PROVINCIAS & $\mathrm{N}^{\circ}$ MUSEOS \\
\hline ALMERÍA & 1 \\
\hline CÁDIZ & 7 \\
\hline CÓRDOBA & 5 \\
\hline GRANADA & 11 \\
\hline HUELVA & 1 \\
\hline JAÉN & 2 \\
\hline MÁLAGA & 2 \\
\hline SEVILLA & 5 \\
\hline TOTAL & 34 \\
\hline
\end{tabular}

Tabla 4. Museos que remitieron la encuesta cumplimentada

El formulario está constituido por las siguientes preguntas:

1. ¿Dispone el museo de Departamento o Área de Conservación?, ¿Cómo lo denominan?.

2. ¿El Departamento de Conservación es visitable?.

3. ¿Dispone el museo de laboratorio o taller de restauración?.

4. ¿Dispone el museo de personal técnico encargado de la conservación-restauración de las obras?.

5. ¿La plantilla es suficiente? ¿Cuántos miembros la integran?.

6. ¿Qué formación poseen?.

7. ¿Pertenece el personal a alguna Asociación?.

8. ¿El Departamento de Conservación ofrece servicios profesionales a coleccionistas, artistas e instituciones culturales que requieran de evaluación, análisis y conservación de obras? ¿Cuál es su tarifa?. 
9. ¿Qué instrumentos de investigación y mantenimiento de la colección posee el museo?.

10. ¿Qué líneas generales de investigación lleva a cabo el Departamento de Conservación del museo?.

11. ¿Realiza programas o actividades orientadas a fomentar el principio de custodia compartida de la colección del museo?.

12. ¿Colabora con otras instituciones del ámbito de la preservación de los bienes culturales?.

13. ¿Dispone el departamento/área de la seguridad e higiene en el trabajo? ¿de qué lo compone?.

14. ¿De qué nuevos medios tecnológicos dispone el departamento/área/taller/laboratorio de conservaciónrestauración del museo?.

15. ¿Qué objetivos, programas y recursos ofrece el departamento de conservación-restauración?.

16. ¿Por qué ley se rige el Departamento de conservaciónrestauración?.

17. ¿Dispone de un Plan de Protección de Colecciones ante Emergencias?.

18. ¿Dispone el museo o departamento de un boletín u otro tipo de publicaciones periódicas?.

19. ¿Dispone de documentación de conservación? ¿Se puede consultar por los usuarios o es de uso interno?.

20. ¿Qué requisitos son necesarios para acceder al puesto de conservador y restaurador?.

21. ¿El departamento ofrece becas de formación de conservación-restauración de obras?.

Como ya sabemos, es importante que la institución tenga en cuenta una serie de medidas, factores y circunstancias para llevar a cabo el correcto mantenimiento y conservación de los fondos del museo -y del propio edificio-. 
Para que esta labor se desarrolle con normalidad es necesario que el centro esté dotado de un Departamento o Área integrado por diferentes especialistas profesionales que se encarguen de realizar las tareas de conservación y restauración de la colección -entre otras cuestiones relacionadas con las mismas-, por lo que deben contar con una plantilla lo suficientemente amplia para que puedan afrontar las actividades y restauraciones sin contratiempos.

Por supuesto, este personal tiene que estar dotado de una titulación académica, siendo las más comunes la Diplomatura en Conservación y Restauración de Bienes Culturales, la Licenciatura en Bellas Artes -especialidad en Conservación y Restauración-, la Licenciatura en Historia del Arte y la especialidad en Museología. Encontrando otras más específicas según el tipo de institución: Paleontología, Guarnicionería, Arqueología, Pedagogía, Licenciatura en Historia y Ciencia de la Música, Taxonomía, Antropología, Derecho, Ciencias Ambientales, Biología...

Accediendo al puesto de trabajo, en la mayoría de los casos, a través de concurso público u oposición -Conservador de Museos, Ayudante de Museos o Restaurador-, o por contratación interna.

Parte de este personal pertenece a alguna Asociación relacionada con el mundo de la museología y conservación del Patrimonio ${ }^{421}$. Ejemplos de éstas son: el ICOM (International

421 Para algunos museos es un dato que forma parte de la privacidad protegido por la ley de protección de datos, por lo que no pueden facilitar la información. 
Council of Museums), la Asociación de Museólogos de España, IIG Grupo Español de arte contemporáneo, el COLBBA (Ilustre Colegio Oficial de Doctores y Licenciados de Bellas Artes de Sevilla) o las Asociaciones que colaboran con el museo: la Asociación de Guías Voluntarios del Museo de Cádiz, la Asociación de Amigos del Museo Onubense, la Asociación de Amigos del Museo de Bellas Artes de Sevilla, la Asociación de Amigos del Museo de Artes y Costumbres Populares de Sevilla o la Asociación de Amigos del Museo Casa de los Tiros.

Un requisito imprescindible en todo museo sería la oferta de realización de becas de prácticas y formación en conservación y restauración para estudiantes e investigadores. Unas, mediante convenio con Universidades españolas para que los alumnos de últimos cursos de licenciatura o Máster realicen las prácticas en el centro -ya sean remuneradas o no-, otras para la formación en instituciones extranjeras.

Para algunos centros los datos relativos a las becas o contratación debe solicitarse a la Consejería de Cultura.

Los Departamentos pueden denominarse de diferente manera según el tipo de institución, así podemos encontrar términos como: Departamento de Conservación e Investigación, Departamento de Conservación y Restauración, Departamento Museístico, Departamento de Conservación -que se ocupa de los temas relacionados con la investigación, protección, conservación y difusión-, Área de Reserva, Área de Restauración, Área de Conservación-Restauración o Talleres de 
Intervención - se centran específicamente en la intervención, conservación, restauración y almacenamiento de los bienes- ${ }^{422}$.

Uno de los medios para que las actividades, investigaciones y avances que se estén desarrollando y produciendo en el museo se den a conocer a la sociedad -tanto a personal investigador como a otro tipo de público- es que este departamento sea visitable, así como disponer de un boletín u otro tipo de publicaciones periódicas.

Muchos de los centros que han participado en la investigación afirman que el departamento o talleres de intervención no son visitables -salvo excepciones y por cuestiones de seguridad de las obras-, en otros, solamente puede ser visitado el lugar donde se realizan las labores de mantenimiento de las piezas y únicamente pueden visitarlo grupos integrados por estudiantes, personal investigador y técnico acreditado relacionado con la conservación del Patrimonio -previa concertación de cita-. Otras instituciones, en cambio, han recibido a grupos de escolares que han participado en otras actividades del museo Departamento Pedagógico-.

Establecer los objetivos, programas y recursos de una institución es fundamental para lograr y realizar con éxito sus pretensiones y actividades -a corto o a largo plazo-, ya que permiten enfocar los esfuerzos de los trabajadores del museo hacia una misma meta.

422 Se denominan de la misma manera en los Museos Arqueológicos: Departamento de Conservación e Investigación, dentro del cual se integra el Área de Restauración y Conservación. 
Entre los objetivos, programas y recursos de algunas instituciones destacan:

- Realizar un proyecto de almacenamiento que permita ampliar las posibilidades de almacenaje mediante la compactación. Asimismo, crear un almacén para elementos pesados y un módulo de reserva visible o almacén visitable con lo más selecto de la colección no expuesta.

- Rescatar, conservar, preservar, restaurar, difundir y asesorar el Patrimonio Histórico de la ciudad.

- Conservación preventiva de áreas de fondos.

- Restauración de las piezas.

- Ampliación, catalogación e investigación de la colección.

- Adecuación de las distintas colecciones y la obra en depósito.

- Participar en investigaciones con otras instituciones y asociaciones de ámbito nacional e internacional en tema de conservación y restauración.

- Documentación, ordenación y gestión informatizada de los Bienes Culturales.

- Control medio ambiental del museo.

- Intervenciones de conservación "in situ" en excavaciones.

- Conservación y restauración de materiales arqueológicos procedentes de las excavaciones realizadas en el municipio.

- Inventario y Catalogación de Fondos Museográficos dentro del sistema Integrado de Documentación y Gestión Museográfica DOMUS. 
- Préstamos, depósitos y donaciones, además de la redacción de documentación, memorias y archivos.

- Gestión de solicitudes de ayudas y subvenciones ofertadas por las Administraciones Públicas.

Tanto las investigaciones realizadas dentro del museo, como en las que participa fuera de la institución, en temas que están en relación con sus objetivos, son una labor interdisciplinar que tiene que estar relacionado con todas las áreas del museo. Es por ello por lo que numerosos centros colaboran con otras instituciones -el Ministerio de Cultura, la Consejería de Cultura de la Junta de Andalucía, Universidades, el Instituto Andaluz de Patrimonio Histórico, el Grupo Español de Arte Contemporáneo IIC...- en proyectos conjuntos del ámbito de la preservación de los Bienes Culturales. Además, esta colaboración se basa en préstamos de obras, depósitos o comodatos.

Entre las líneas de investigación que se están llevando a cabo son:

- Redacción de guías divulgativas en tres formatos para el profesor, el guía turístico y el intérprete del patrimonio-.

- Investigación de la historia del museo.

- Participación en equipos de investigación universitarios.

- Análisis y estudio de las obras (técnicas, materiales, estado de conservación, intervención, documentación, restauración, difusión, puesta en valor...) .

- Identificación, catalogación, ampliación y conservación de la colección. 
- Investigación sobre el personaje al que se dedica el museo (Picasso, Mariana Pineda...).

- Caracterización de materiales contemporáneos (filmógenos, plásticos, fotografía, art media, nuevos materiales...).

Para ello se sirven de instrumentos de investigación como el catálogo, el registro, el inventario, diferentes bases de datos (Knosys, Access, Excel...) y el sistema informatizado de gestión integral de los fondos museográficos y documentales (DOMUS). Además de disponer de salas para atender a los investigadores externos -nacionales e internacionales- y bibliotecas especializadas con numerosos volúmenes de varias ramas científicas (Prehistoria, Historia Antigua, Arqueología, Museología, Museografía, Conservación, Restauración, Patrimonio...) y con documentación de las distintas colecciones de la institución.

Para el mantenimiento de las colecciones los museos se dotan de vigilancia constante por parte del personal cualificado y sistemas de control de la temperatura, humedad e iluminación -tanto individualmente en las vitrinas que contienen piezas como en las salas de exposición y almacenamiento- para conocer la influencia de la climatología y de la afluencia de público sobre los objetos expuestos. Igualmente están dotados de alarmas volumétricas encargadas de detectar cualquier movimiento de la presencia humana dentro de un campo láser que se acciona cuando el museo esta cerrado al publico y que se encuentra conectada con una centralita. 
En ciertos casos es el propio taller de restauración el que se encarga de la conservación de las mismas, realizando periódicamente un estudio de ellas.

En lo que respecta a la documentación de las colecciones y los archivos donde se localizan los expedientes de investigación, préstamos de las piezas -para investigadores o exposiciones temporales-, informes de conservación y restauración de las obras, y otros datos referentes al museo, normalmente suele estar sujeto a varias leyes (Ley de Archivos, Protección de Datos...) que hacen que su consulta sea de uso interno a la institución, aunque en algunos casos puede ser accesible a los usuarios que justifiquen su investigación previa solicitud a la dirección del centro.

Actualmente, muchos son los museos que disponen de esta información -la mayor parte de la documentación- para su consulta en la página web del mismo.

Otra cuestión importante a tener en cuenta es la seguridad en el trabajo y la salud del trabajador. El museo conserva sus fondos con el fin de transmitirlo en las mejores condiciones posibles a las generaciones futuras. De tal manera que se verá en la responsabilidad de proteger y conservar el Patrimonio a toda la sociedad. Para ello deberá encargarse del aspecto de la seguridad y protección que en él se depositan, el propio edificio -y el espacio circundante-, así como velar por la seguridad de sus trabajadores y, por supuesto, de sus visitantes.

Por este motivo es de especial importancia que el Departamento -y el museo- se rija por la legislación vigente en tema de Seguridad e Higiene, además de disponer del Plan 
de Protección de Colecciones ante Emergencias. Algunos centros sí cuentan con este Plan, otros se encuentran en proceso de elaboración o carecen de él.

Asimismo, el personal de la institución deberá acudir a los cursos de formación oficiales para responder a las exigencias de dicho plan.

Del mismo modo, el Departamento deberá estar dotado de elementos de protección contra los diferentes riesgos que puedan sufrir durante la intervención y manipulación de las piezas. Entre los museos analizados encontramos elementos y sistemas de protección como: guantes, gafas, campanas extractores de humo y emanaciones volátiles, mascarilla, armario para productos tóxicos (disolventes, aglutinantes, adhesivos, ácidos, resinas sintéticas, inhibidores de la corrosión, etc.), detectores de incendio y robo, mangueras de agua, extintores, salidas de emergencia, fuentes de lavado de ojos, señalización -obligación de uso, prohibición e informativa-, auriculares, ropa de protección y botiquín.

La dotación de un laboratorio o taller de restauración en el propio Departamento es de gran ayuda a la hora de analizar y estudiar una pieza o material en un determinado momento, y si está dotado de equipos y nuevos medios tecnológicos, aún mejor. En algunas instituciones poseen un programa de fumigación anual, realizan limpiezas periódicas de almacenes y salas de exposición incluyendo los dispositivos de exposición (pedestales, vitrinas...), disponen de control monitorizado de las condiciones de humedad relativa y temperatura mediante monitores Hanwell ${ }^{423}$ -

423 Para mayor información, consultar

http://www.hanwell.com/index.php. 
conectados por radio a una central residente en un puesto informático conectado en red con los ordenadores del personal técnico-, termohigrómetros, termohigrógrafos, luxómetros, cámara climática, cámara estanca para fumigación, destilador de agua, equipo láser para piedra, equipos de ultrasonidos, microhidroabrasímetros ${ }^{424}$, maquinaria automatizada para el mecanizado de piezas industriales, un Centro de Mecanizado CNC (Control Numérico) ${ }^{425}$, calentadores industriales leister, aerógrafos, mini-mesa de succión y caliente Mitka ${ }^{426}$, torno paralelo con pantalla de visualización de cotas, equipo de soldadura $\mathrm{TIG}^{427}-\mathrm{MIG}^{428}$, fresadora universal, taladros de columna y plegadora-curvadora-cizalla.

Gracias a estas nuevas tecnologías e instalaciones en los museos, muchos de ellos realizan servicios profesionales externos a otras instituciones que requieren el análisis de obras. En el caso de los museos públicos sujetos a la legislación general de la administración, no pueden prestar este tipo de servicios ya que es incompatible. En algún caso se han llevado a cabo a instancias del Ayuntamiento de la localidad o atienden consultas puntuales, principalmente las provenientes de otras instituciones públicas. En cambio, los centros privados y no dependientes del Estado, realizan estas actividades ya sea de manera gratuita o a través de una tarifa de precios.

${ }^{424}$ Instrumento aeroabrasivo con control electrónico utilizado en la limpieza de piedra, madera, materiales arqueológicos, mosaicos, pinturas al fresco...

425 Aparato que realiza cualquier tipo de trabajo en piedra, ya sea natural o sintética. Sustituye al trabajo artesanal.

${ }^{426}$ Mesa utilizada para la conservación de pinturas, papel y textil.

427 Soldadura por arco de gas Tungsteno.

428 Soldadura por arco metálico con gas. 
Para que todo lo expuesto anteriormente se realice correctamente, el museo se debe regir por ciertas leyes, algunas de ellas son:

- Ley de Patrimonio Histórico Español, 1985.

- Ley de Patrimonio Histórico de Andalucía, 2007.

- Ley de Museos y Colecciones Museográficas de Andalucía, 2007.

- Ley de Régimen Jurídico de las Administraciones Públicas y el Procedimiento Administrativo Común.

- Reglamento de Actividades Arqueológicas.

- Reglamento de Museos de Titularidad Estatal y del Sistema Español de Museos.

\section{DATOS OBTENIDOS DE LAS ENCUESTAS}

Número de Respuestas obtenidas: 


\begin{tabular}{|c|c|c|c|}
\hline PREGUNTA $\mathrm{N}^{\circ}$ & SI & NO & SIN RESPUESTA \\
\hline 1 & 23 & 10 & 1 \\
\hline 2 & 15 & 10 & 10 \\
\hline 3 & 24 & 8 & 2 \\
\hline 4 & 30 & 3 & 1 \\
\hline 5 & 9 & 21 & 4 \\
\hline $6^{429}$ & & 1 & 1 \\
\hline 7 & 10 & 14 & 10 \\
\hline 8 & 4 & 19 & 11 \\
\hline $9^{430}$ & & 3 & 5 \\
\hline $10^{431}$ & & 2 & 4 \\
\hline 11 & 13 & 12 & 9 \\
\hline 12 & 17 & 6 & 11 \\
\hline 13 & 27 & 4 & 3 \\
\hline 14 & 12 & 9 & 13 \\
\hline $15^{432}$ & & 2 & 14 \\
\hline $16^{433}$ & & 2 & 7 \\
\hline 17 & 15 & 11 & 8 \\
\hline 18 & 12 & 13 & 9 \\
\hline 19 & 26 & 4 & 4 \\
\hline $20^{434}$ & & & 8 \\
\hline 21 & 3 & 16 & 14 \\
\hline TOTAL & 240 & 170 & 149 \\
\hline
\end{tabular}

Al respecto hay que decir que:

\footnotetext{
429 Pregunta abierta.

430 Pregunta abierta.

431 Pregunta abierta.

432 Pregunta abierta.

433 Pregunta abierta.

434 Pregunta abierta.
} 
- El 67,64\% de las instituciones poseen Departamento o Área de Conservación-Restauración.

- El 44,11\% de los Departamentos son visitables.

- $\operatorname{El} 70,58 \%$ de los museos disponen de taller o laboratorio de restauración.

- El 88,23\% de los museos de Andalucía dispone de personal técnico encargado de la conservaciónrestauración de las obras.

- El 26,47\% de los centros poseen una plantilla suficiente para abordar los trabajos de conservación-restauración.

- El 29,41\% del personal pertenece a alguna Asociación.

- El 23,52\% de los museos ofrece servicios profesionales a coleccionistas, artistas e instituciones culturales que requieran de evaluación, análisis y conservación de obras.

- El 38,23\% de los Departamentos realiza programas o actividades orientadas a fomentar el principio de custodia compartida de la colección del museo.

- El 50\% de los museos colabora con otras instituciones del ámbito de la preservación de los bienes culturales.

- El 79,41\% de los Departamentos de ConservaciónRestauración dispone de la seguridad e higiene en el trabajo.

- El 35,29\% de las instituciones disponen de nuevos medios tecnológicos.

- El 44,11\% de los centros museísticos dispone de un Plan de Protección de Colecciones ante Emergencias.

- El 35,29\% de los museos posee un boletín u otro tipo de publicaciones periódicas. 
- El 76,47\% dispone de documentación de conservación y restauración de obras.

- El 8,82\% de las instituciones ofrece becas de formación de conservación-restauración de Bienes culturales.

En general se ha observado un gran número de preguntas sin responder quedando su respuesta ausente de información.

Estos resultados indican que escasos museos andaluces son los que cuentan con unos Departamentos de ConservaciónRestauración en correctas condiciones: personal, equipamientos, instalaciones, seguridad... Aunque, según las instituciones, la plantilla que forma parte de la sección de mantenimiento, conservación y restauración de las obras es escasa en la mayoría de ellos.

En cuanto a los recursos e instalaciones se observa claramente que se necesitan importantes mejoras, ya que un escaso porcentaje de las instituciones museísticas cuentan con equipos en continua renovación permitiendo así el acceso a los métodos de estudio de la colección. Para la realización de análisis de obras apenas se tienen medios en el laboratorio -si lo hay- por lo que se requiere el servicio de profesionales externos a la institución.

Esto es debido a varios factores, entre ellos podemos señalar la situación económica del museo -por lo que no han podido introducir nuevos medios tecnológicos en los últimos años-, el hecho de ser un museo de nueva creación -se está adecuando a las nuevas tecnologías-, por la no disposición de medios propios o porque sus instalaciones son muy anticuadas. 


Otro dato importante a tener en cuenta es que en
escasos centros se cuentan con un riguroso Plan de
Colecciones ante Emergencia, ya sea para evacuar las obras de
la institución como para saber cómo actuar en caso de
acciones de delincuencia (robos o desapariciones de piezas).

De la misma manera, en casi la totalidad de los casos no se ofertan becas de formación para estudiantes e investigadores. En este sentido es necesario romper con esta falta ya que este servicio brinda la oportunidad a jóvenes investigadores a poner en práctica los conocimientos adquiridos a lo largo de su carrera académica y así continuar investigando y avanzando en la conservación y restauración del Patrimonio.

Así, una vez contrastados los datos se descubre la precariedad de personal y medios con los que cuentan los Departamentos de Conservación-Restauración de numerosos museos andaluces, tanto públicos como privados.

Puede añadirse, que de forma general, se observan valoraciones positivas en cuanto a la colaboración en investigación y realización de proyectos conjuntos con otras instituciones del ámbito de la conservación de los Bienes culturales.

Igualmente, un gran porcentaje de instituciones museísticas dispone de la adecuada seguridad e higiene en el trabajo y para el trabajador. 


\section{ANÁLISIS DAFO}

\section{FORTALEZAS}

1. Un gran número de instituciones de Andalucía disponen de Departamento o Área de Conservación y Restauración.

2. Numerosos museos poseen taller o laboratorio de Conservación-Restauración y análisis de materiales.

3. Un alto porcentaje de los centros cuentan con personal técnico encargado de la conservación-restauración de las obras.

4. La mayoría de los trabajadores cuentan con titulación académica.

5. Los convenios de colaboración, el intercambio de información y documentación entre distintas instituciones, tanto nacionales como internacionales.

6. La colaboración en investigación y realización de proyectos conjuntos con otras instituciones del ámbito de la conservación de los Bienes Culturales.

7. Adecuada seguridad e higiene en el trabajo y para el trabajador.

8. Disposición de documentación en conservación.

\section{DEBILIDADES}

1. Pocos Departamentos son visitables.

2. Escasa infraestructura en los Departamentos.

3. Plantilla insuficiente de trabajadores y auxiliares para atender a las necesidades de conservación y restauración de la colección.

4. Instalaciones obsoletas. 
5. Bajo nivel tecnológico.

6. Los costes para mantener o mejorar los recursos materiales o humanos son muy elevados y los presupuestos son deficientes.

7. Los espacios dedicados a la conservación y restauración de las piezas son insuficientes.

8. Escaso interés en la realización y oferta de becas para estudiantes e investigadores.

9. Carencia de formación específica para el personal técnico de museos.

10. Falta de realización de programas o actividades orientadas a fomentar el principio de custodia compartida de la colección del museo.

11. Los índices de publicaciones periódicas o boletines del museo son bajos.

12. Escaso personal trabajador pertenece a Asociaciones relacionadas con la Conservación-Restauración, Museología o Patrimonio.

13. Falta del Plan de Protección de Colecciones ante Emergencias.

\section{OPORTUNIDADES}

1. Obtener mayor presupuesto para construir las instalaciones necesarias.

2. Aprovechar los avances en las nuevas tecnologías para el análisis de obras.

3. Cooperar con otras instituciones internacionales en el estudio e investigación en Conservación-Restauración.

4. Aprovechar la nueva oferta profesional -técnicos y profesionales altamente capacitados- con la implantación de los estudios del Plan Bolonia. 
5. Ampliar la oferta de becas para estudiantes e investigadores.

\section{AMENAZAS}

1. Se presentan carencias y necesidades significativas en la mayoría los museos con relación a la infraestructura del Departamento.

2. Insuficiente desarrollo en equipamiento tecnológico.

3. El avance de la tecnología, así como la utilización y uso de los equipos, hace necesaria la implantación de proyectos de mantenimiento y modernización de los mismos.

4. Escasa participación de jóvenes recién licenciados en la realización de prácticas o becas en las instituciones.

5. La situación económica de la institución.

6. Escasa atención a la seguridad de las obras respecto al Plan de Protección de Colecciones ante Emergencias.

\section{ESTRATEGIAS}

1. Rediseñar un programa administrativo eficiente.

2. Ampliar las visitas de público al Departamento para dar a conocer la labor en conservación-restauración.

3. Consolidar y ampliar la oferta formativa.

4. Diseñar medidas que mejoren la seguridad de la colección y el trabajador del centro.

5. Dotar de nuevos recursos para la conservación de las colecciones.

6. Fomentar la participación de jóvenes voluntarios y becados. 
7. Mejorar y ampliar las instalaciones para la conservación y restauración de las piezas.

8. Optimizar los equipos instalados reduciendo los obstáculos de las innovaciones científicas implantando programas de mantenimiento y modernización de la infraestructura en el Departamento.

9. Aplicar nuevos programas informáticos en lo referente al proceso de tratamiento y análisis de las piezas.

10. Fortalecer la presencia de boletines o publicaciones electrónicas para dar a conocer a la sociedad la institución y la actividad que lleva a cabo.

11. Integrar la formación profesional al mundo del trabajo, proponiendo la implantación de mayor número de becas, con lo que se reduciría considerablemente el desempleo y la falta de puestos en el museo. 


\section{CONCLUSIONES}

El objetivo inicial de esta investigación era conocer el estado y la situación actual de los Departamentos o áreas de Conservación-Restauración de los museos de Andalucía. Al respecto es necesario señalar que en nuestro país, y en concreto en Andalucía, se han realizado insuficientes investigaciones sobre los Departamentos de ConservaciónRestauración de los museos que han aportado resultados escasos y parciales sobre esta situación.

Así pues, de esta labor de búsqueda y análisis se deducen una serie de conclusiones relevantes, no ya tan sólo para entender el funcionamiento de un Departamento de Conservación-Restauración de una institución museística, sino también para valorar el grado de organización interna.

Uno de los principales problemas a los que se enfrentan muchas instituciones es la carencia de personal. La mayoría solamente cuentan con un restaurador que, en muchas ocasiones, tiene que atender otras funciones del museo debido a la falta de personal. Además, y desafortunadamente, muchos de los Departamentos no cuentan con un equipo interdisciplinar. Igual de importante para la buena realización de la funciones de conservación-restauración es la infraestructura y dotación de Laboratorios con los que cuenta el museo, así como de los equipos de análisis y tratamientos de obras necesarios. 
Por tanto, una vez contrastados los datos se descubre la precariedad de personal y medios con los que cuentan los Departamentos de Conservación-Restauración de numerosos museos andaluces, tanto públicos como privados. En cuanto a los recursos e instalaciones se observa claramente que se necesitan importantes mejoras. Para la realización de análisis de obras apenas se tienen medios en el laboratorio si lo hay- por lo que se requiere el servicio de profesionales externos a la institución.

De la misma manera, en casi la totalidad de los casos no se ofertan becas de formación para estudiantes e investigadores.

De forma general, se observan valoraciones positivas en cuanto a la colaboración en investigación y realización de proyectos conjuntos con otras instituciones del ámbito de la conservación de los Bienes Culturales.

Igualmente, un gran porcentaje de instituciones museísticas dispone de la adecuada seguridad e higiene en el trabajo y para el trabajador.

En la búsqueda de un modelo de Departamento bien estructurado y organizado, tanto la sociedad como los órganos Gubernamentales juegan un papel esencial, teniendo en cuenta, además, los aspectos sociales, económicos, culturales, políticos... de la comunidad andaluza. Ya que, como dijo Albert Szent-Györgyi ${ }^{435}$, la investigación se compone de cuatro cosas: el cerebro con el que se piensa, los ojos, las máquinas para medir $y$, en cuarto lugar, el dinero.

435 Bioquímico nacido en Budapest (1893-1986) que obtuvo el Premio Nobel en Medicina en 1937. 
Por tanto, los resultados obtenidos indican que escasos museos andaluces son los que realmente cuentan con unos Departamentos de Conservación-Restauración en correctas condiciones de personal, equipamientos, instalaciones y seguridad.

A través de la investigación tanto teórica como práctica de estos centros, se buscaron estrategias para resolver la problemática existente en ellos y por tanto, mejorar su situación actual. De este modo, la propuesta de mejora de los Departamentos de Conservación-Restauración es:

- Rediseñar un programa administrativo eficiente.

- Ampliar las visitas de público general al Departamento para dar a conocer la labor en conservaciónrestauración.

- Consolidar y ampliar la oferta formativa.

- Diseñar medidas que mejoren la seguridad de la colección y del trabajador del centro.

- Dotar de nuevos recursos para la conservación de las colecciones.

- Fomentar la participación de jóvenes voluntarios y asociaciones profesionales.

- Mejorar y ampliar las instalaciones para la conservación y restauración de las piezas.

- Optimizar los equipos instalados reduciendo los obstáculos de las innovaciones científicas implantando programas de mantenimiento y modernización de la infraestructura en el Departamento.

- Aplicar nuevos programas informáticos en lo referente al proceso de tratamiento y análisis de las piezas. 
- Fortalecer la presencia de boletines o publicaciones electrónicas para dar a conocer a la sociedad la institución y la actividad que lleva a cabo.

- Integrar la formación profesional al mundo del trabajo, proponiendo la implantación de mayor número de becas, con lo que se reduciría considerablemente el desempleo y la falta de puestos en el museo.

Para concluir, dado que es de vital importancia conocer el estado de nuestro legado cultural para transmitirlo a generaciones venideras, la investigación debe continuar para saber y conocer el estado de los distintos Departamentos de los museos de Andalucía y el resto de España, si se dirigen por el camino correcto o si hay que rectificar algunos aspectos importantes para el buen funcionamiento de los mismos en un futuro próximo.

De esta manera, todo el Patrimonio que poseemos debemos conservarlo, protegerlo y difundirlo, además de investigarlo y fomentarlo, para que no desaparezca y sea, por tanto, conocido y valorado por toda la sociedad. 


\section{BIBLIOGRAFÍA}

- AA. VV. "Caracterización de material óseo arqueológico mediante el uso de Ablación Láser Pulsada acoplada a Espectroscopía de Emisión Óptica (LAP-OES)". En Jornadas de Avances de Técnicas Analíticas Aplicadas al Estudio de Materiales en Arte y Arqueología (TECNARTE), Universidad de Buenos Aires (Argentina), 11-13 de junio de 2008.

- AA. VV. Conservación de colecciones de Arte e Historia y Arqueología. Manual básico de Conservación preventiva. Museo Nacional de Colombia. Bogotá, septiembre de 2002.

- AA. VV. "El programa de exposición del Museo del Ejército". En Museos.es, N³ 3, 2007, pp. 110-119.

- AA. VV. "El proyecto Público y Museos". En Museo, No 3, 1998. pp. 123-148.

- AA. VV. "El público y el Museo". Mus-A, No 10, octubre 2008 .

- AA.VV. "Biblioteca digital del Instituto del Patrimonio Cultural de España". Ministerio de Cultura.

http://www.mcu.es/patrimonio/MC/IPHE/Biblioteca/BibliotecaDig ital.html (Consultado el 8 de julio de 2010).

- AA. VV. Curso de Iniciación a la Conservación del Patrimonio. Centro de enseñanza virtual Liceus. Madrid. Universidad de Alcalá, 2007.

- AA. VV. Normativas técnicas para Museos.

http://museosdevenezuela.org (consultado el 26 de julio de 2010).

- AA. VV. Proyecto Museológico y Museográfico. Atarazanas. Museo de Arte Contemporáneo. II Master Universitario en Museología. Granada. Universidad de Granada, 2004. 
- ABAD LICERAS, José María. "La protección nacional e internacional de los bienes culturales en caso de conflictos armados". En Noticias Jurídicas, octubre de 1998. http://noticias.juridicas.com/articulos/00-

Generalidades/199810-not20 2.html (consultado el 13 de octubre de 2010).

- AisA López, Luisa María. "La problemática de la Biblioteca en nuestros Museos". En ANABAD, Tomo 38, $\mathrm{N}^{\circ} 3$, 1988. pp. 43-46.

- Alaminos López, Eduardo. "El acceso a los museos: evolución histórica". En ANABAD, Tomo 40, $\mathrm{N}^{\circ} 2-3,1990$, pp. 173-178.

- AlCANTARILlA, Jesús. "La seguridad en los activos y actividades del Patrimonio Histórico Artístico". En Seguritecnia, Revista decana independiente de seguridad. $\mathrm{N}^{\circ}$ 329, abril 2007 .

http://www.borrmart.es/articulo seguritecnia.php?id=1394\&nume ro=329 (consultado el 16 de agosto de 2010).

- AlfARo, Laura... et alt. "Laboratorio de Conservación y Restauración de Colecciones en Papel de la CNEA: tratamiento de libros y documentos atacados por microorganismos usando rayos gamma. En CNEA, año 9, $N^{\circ}$ 35-36, julio/diciembre de 2009. pp. 31-35.

- ALQUÉzAr YÁneZ, Eva Ma . "Domus, un sistema de documentación de museos informatizado. Estado de la cuestión y perspectivas de futuro". En Desde el Museo, pp. 28-41.

- Antigüedad DEl CAstillo-olivares, María Dolores. "El Museo de la Trinidad y el origen del museo público en España". En Espacio, tiempo y forma, $\mathrm{N}^{\circ} 11,1998$. pp. 367396.

- APICI (Asociación de Ingeniería de Protección contra Incendios). "La seguridad contra incendios en los museos españoles en peligro". En Belt Ibérica S.A. 
http://www.belt.es/expertos/experto.asp?id=1675, julio-agosto de 2003. (Consultado el 15 de agosto de 2010).

- APROBIC (Asociación para la Protección de los Bienes de Interés Cultural). "Seguridad contra los incendios en museos". En Belt Ibérica S.A. http://www.belt.es/expertos/experto.asp?id=1676, octubre de 2003. (Consultado el 15 de agosto de 2010).

- AQuilar majarón, Isabel. "El discurso del Museo Etnológico de Osuna". En Amigos de los Museos de Osuna. $\mathrm{N}^{\circ}$ 8, 2006, pp. 57-61.

- ARCos, Eduardo. "Ventajas del uso de focos (bombillas) de bajo consumo en tu casa". En ALT1040, Actualidad, 20 de febrero de 2007. http://alt1040.com/2007/02/ventajas-deluso-de-focos-bombillas-de-bajo-consumo-en-tu-casa

(consultado el 24 de septiembre de 2010).

- ARIAS SERRANo, Laura. "El papel del público en el museo de hoy". En ANABAD, Tomo 40, No 2-3, 1990, pp. 178-188.

- ARQUillo TORRES, Francisco. "El componente artístico en la formación del restaurador". En VIII Congrés de conservació de Bens Culturals, 20-23 de septiembre de 1990, Valencia. pp. $21-23$.

- ASEnsio, Mikel, POL, Ana. "¿Para qué sirven hoy los estudio de público en museos?". En Revista de Museología, $N^{\circ}$ 24-25, 2002, pp. 11-20.

- BARONA VILAR, Josep Lluis. "Los laboratorios de la Junta para Ampliación de Estudios e Investigaciones Científicas (J.A.E.) y la Residencia de Estudiantes (1912-1939)". En Asclepio, Revista de historia de la medicina $y$ de la ciencia, Volumen 59, Fascículo 2, 2007, pp. 87-114.

- BARRACA DE RAMOS, Pilar. "Algunos aspectos de la documentación en los Museos". En ANABAB, Tomo 44, No 1, 1994 , pp. 135-151. 
- BELLIDO GANT, Ma Luisa. Arte, museos y nuevas tecnologías. Gijón. Trea, 2001.

- (dir.). Difusión del Patrimonio Cultural y Nuevas Tecnologías. Sevilla. Universidad Internacional de Andalucía, 2008.

- Museos virtuales y digitales.

http://museosvirtuales.wordpress.com/2009/02/04/m useos digitales/, 4 de febrero de 2009.

(Consultado el 30 de junio de 2010).

- BERNAL MARTÍNez, José Mariano... et alt. "La Junta para Ampliación de Estudios (JAE) y la enseñanza de la ciencia para todos en España". En Revista de educación, No Extra 1, 2007. pp. 215-240.

- BERTAUX, JEAN-JACQUES. "La formación y selección de los responsables de museos en Francia". En Museo, No 1, 1996. pp. 85-102.

- BIMUS. Red de Bibliotecas de Museos. Ministerio de Cultura. Gobierno de España.

http://wWw.mcu.es/museos/MC/BIMUS/index.html (consultado el 22 de septiembre de 2010).

- BLANCO DOMíngUEZ, Manuel... et alt. "Caracterización de tratamientos de limpieza mediante Microscopía Confocal". En MACLA, Revista de la Sociedad Española de Mineralogía, $\mathrm{N}^{\circ}$ 9, Septiembre de 2008. pp. 57-58.

- BORELLI, Ernesto. "Investigación y nuevas tecnologías: consideraciones críticas". En Actas del I Congreso del GEIIC. Conservación del Patrimonio: evolución y nuevas perspectivas. 25, 26 y 27 de Noviembre de 2002.

- BORREL, Arelys... et alt. "Lineamientos para la conservación de documentos en la Biblioteca Médica Nacional de Cuba". Biblioteca Virtual en Salud, Cuba, 2005. http://bvs.sld.cu/revistas/aci/vol12 5 04/aci12504.htm

(Consultado el 2 de Agosto de 2010). 
- BOYLAND, Patrick J. "Los profesionales de los museos: su función y su definición". En Revista de Museología, Nº 5, 1995. pp. 13-18.

- BRANDI, Cesare. Teoría de la Restauración. Madrid, 1989.

- BRAVO JUEGA, Isabel. "Un capítulo fundamental en la Museología: la seguridad en los museos". En ANABAD, XXXII, 1982, $\mathrm{N}^{\circ}$ 3, pp. 319-323.

- El sistema de Documentación de Museos Militares del Ministerio de Defensa: el Museo del Ejército, modelo de actuación. Madrid. Ministerio de Defensa, 2000 .

- "Documentación o investigación". En Museo, $\mathrm{N}^{\circ}$ 2, 1997, pp. 91-94.

- BRUQUeTAS GALÁN, Rocío. "La conservación preventiva: una nueva profesión con una vieja historia". En Curso sobre Exposiciones temporales y conservación del Patrimonio. Grupo Español del IIC. Facultad de Geografía e Historia de la Universidad Complutense de Madrid. Madrid, 5 al 8 de Abril, 2005.

- caballero zoreda, Luis. "A propósito del Sistema de Documentación para Museos". En ANABAD, XXXIII, 1983, $\mathrm{N}^{\circ} 3$, pp. 493-500.

○ "El museo: funciones, personal y su formación". En ANABAD XXX, $\mathrm{N}^{\circ} 3,1980$, pp. 377-385.

- "Teoría general del museo. Sus funciones". En ANABAD XXVIII, $\mathrm{N}^{\circ}$ 3, 1988, pp. 29-41.

- CAlVO MANUEl, Ana María. "Tendencias actuales en conservación-restauración de pintura". En Actas de los XVI Cursos Monográficos sobre el Patrimonio Histórico. Reinosa, Julio de 2005. p. 163-173.

- CALVO, Ana M... et alt. "Tratamiento de libros y documentos infectados con hongos, utilizando Rayos Gamma. Laboratorio de Conservación y Restauración de colecciones en papel de 
CNEA". Jornadas de Avances de Técnicas Analíticas Aplicadas al Estudio de Materiales en Arte y Arqueología (TECNARTE), Universidad de Buenos Aires (Argentina), 11-13 de junio de 2008. pp. 38-42.

- CAMPS MIRABET, Nuria. La protección internacional del Patrimonio Cultural. Tesis Doctoral. Universidad de Lleida, 2000 .

- CANO DE GARDolui garcía, José Luis. Tesoros y colecciones: orígenes y evolución del coleccionismo artístico. Valladolid. Universidad, 2001.

- CARRERAS I tARRAgo, Anna... et alt. "El papel del conservador-restaurador en el montaje de exposiciones temporales y/o itinerantes". En VII Congreso de Conservación de Bienes Culturales, 23-25 de septiembre 1990. pp. 53-64.

- CARREtero MARCO, Carmen. "Restauración en el siglo XIX. Materiales, técnicas y criterios". En Actas del II Congreso del GEIIC. Investigación en Conservación y Restauración. Barcelona, 9-11 de noviembre de 2005.

- "La restauración de pintura en el Museo del Prado en el siglo XIX. Vicente Poleró y el Real Sitio de San Lorenzo de el Escorial". En Actas del I Congreso del GEIIC. Conservación del Patrimonio: evolución y nuevas perspectivas. Valencia, 25 al 27 de Noviembre, 2002.

- CARRETERo PÉREZ, Andrés. "La documentación en los museos: una visión general". En Museo No 2, 1997, pp. 11-29.

- "Domus y la gestión de las colecciones museográficas". En MARQ, Arqueología y Museos, $\mathrm{N}^{\circ}$ $0,2005, \mathrm{pp} \cdot 17-30$.

- CAsal lópez-VAleiras, José M. "Iluminación en museos (I)". En ANABAD, No 34, Tomo 2-4, 1984. pp. 211-238. 
- CASTELLÓN SERRANO, Federico, MARTínez MAdRID, Rafael. "Didáctica del Museo: el Gabinete Pedagógico de Bellas Artes y el Museo de Málaga". En Jábega, N 92, 2002, pp. 89-99.

- CAstillo RUIz, José. "¿Hacia una nueva definición del patrimonio histórico?: reflexiones sobre el documento "bases para una carta sobre patrimonio y desarrollo en Andalucía". En PH: Boletín del Instituto Andaluz del Patrimonio Histórico, Año $\mathrm{n}^{\circ} 4, \mathrm{~N}^{\circ}$ 16, 1996, pp. 101-106.

- "Los valores propios del patrimonio histórico: gestación y caracterización". En Cuadernos de arte de la Universidad de Granada, $\mathrm{N}^{\circ}$ 29, 1998, pp. 229-239.

- CER.es. Catálogo colectivo de la Red Digital de Colecciones de Museos de España. Ministerio de Cultura. http://ceres.mcu.es (Consultado el 22 de junio de 2010).

- CERRO GONZÁLEZ, Manuel. "Cómo disponer del personal idóneo: conocimientos legales". En Museo, $\mathrm{N}^{\circ}$ 3, 1998. pp. 2533.

- CiRujAno, Concha, Schoebel, Ana. "Calidad en la Conservación y Restauración del Patrimonio artístico". En Actas del II Congreso del GEIIC. Investigación en Conservación y Restauración. Grupo Español del IIC. Universidad de Barcelona. Barcelona, 9 al 11 de Noviembre, 2005.

- Código Deontológico del ICOM para los museos. 2006.

- Comisión de seguimiento de la red de instituciones usuarias de DOMUS. Ministerio de Cultura. Dirección General de Bienes Culturales y Bellas Artes. Subdirección General de Museos Estatales. Madrid, 2 de octubre de 2006.

- "Conceptos de Patrimonio". En Revista Digital Nueva Museología. http://www.nuevamuseologia.com.ar/patrimonio2.htm (Consultado el 7 de julio de 2010). 
- Condiciones técnicas para la contratación menor del servicio de restauración y conservación preventiva de piezas de colección del Museo del Ferrocarril dependiente de la Fundación Municipal de Cultura, Educación y Universidad Popular del Ayuntamiento de Gijón. Ayuntamiento de Gijón, 2008.

- Conservación en los Museos. Ministerio de Cultura. http://www.mcu.es/museos/CE/Funciones/Conservacion/Introducc ion.html (consultado el 10 de septiembre de 2010).

- Conservación y restauración. Museo Guggenheim de Bilbao. http://www.museobilbao.com/conservacion-restauracion.php

(consultado el 1 de agosto de 2010).

- CORRALIZA, José Antonio. "La consideración ambiental del espacio expositivo: una perspectiva psicológica". En ANABAD, Tomo 43, $\mathrm{N}^{\circ}$ 3-4, 1993, pp. 273-282.

- Creación del Centro de Conservación, Restauración y Museología. Resultados y recomendaciones del proyecto. Cuba. París. UNESCO, 1989.

- CRUZ DE LEÓN, J. "El Laboratorio de Conservación y Preservación de la Madera (LACOPREMA)". En II foro académico nacional de Ingenierías y Arquitectura, 6-8 de diciembre de 2006, Morelia (Michoacán), México. pp. 419-427.

- Culubret, Bárbara, HeRnÁndez, Marta, HidAlgo, Encarnación, MARTÍNEZ, Marina, RALLO, Carmen. "Planes de Protección de Colecciones ante Emergencias en los museos estatales españoles. Estado de la cuestión". En FMGB Guggenheim Bilbao Museoa, Bilbao 2007. pp. 1-7.

$\begin{array}{lll}\text { - Guía para un Plan de Colecciones ante } \\ \text { Emergencias. Ministerio de Cultura, } 2008 . & \\ \text {-Gestión de emergencias en museos. } & \text { Las } \\ \text { colecciones, un capítulo pendiente". } & \text { En } \\ \text { Museos.es, } \mathrm{N}^{\circ} \text { 2, } 2006 \text {. pp. 126- } 13 . & \end{array}$


- DÁVIlA BUItRóN, Carmen, MORENo CIFUentes, Ma Antonia. "El laboratorio de restauración del MAN". En $A N A B A D$, Tomo 43, $\mathrm{N}^{\circ}$ 3-4, 1993. pp. 155-176.

- DE GUICHEN, Gaël. "Conservación preventiva: ¿simple moda pasajera o cambio trascendental?". En Museum Internacional (París, UNESCO), $\mathrm{N}^{\circ}$ 201, Vol. 51, $\mathrm{N}^{\circ}$ 1, 1999.

- DE LOS ÁNGELES, Margarita... et alt. "Los estudios de público, un instrumento de trabajo. La gestación de un proyecto". En Mus-A, No 10, 2008, pp. 31-35.

- DE TAPOL, Benoit. "El diálogo entre el conservador y el arquitecto sobre las exigencias climáticas de las colecciones y la aplicación de consignas". En Museos.es, $\mathrm{N}^{\circ}$ 1, 2005, pp. 66-79.

- "¿qué orientación tiene la ciencia en la conservación". En Actas del II Congreso del GEIIC. Investigación en Conservación y Restauración. Grupo Español del IIC. Universidad de Barcelona. Barcelona, 9 al 11 de Noviembre, 2005 .

- "Nuevo proyecto museográfico: una nueva manera de evaluar las condiciones de conservación de una colección". En Revista de Museología, N²9, 2004 . pp. 99-106.

- Decálogo de la Restauración. Criterios de intervención en Bienes muebles. Instituto del Patrimonio Cultural de España (IPCE) . http://www.mcu.es/patrimonio/docs/MC/IPHE/M0901-02-3PDF1.pdf (Consultado el 18 de agosto de 2010).

- Delgado MÉNDEZ, Aniceto. "La difusión del Patrimonio Cultural a través de los Museos: diferentes experiencias en la Provincia de Huelva". En Amigos de los Museos de Osuna. $N^{\circ}$ 9, 2007 . pp. 32-35.

- Departamento de Conservación y Restauración de Bienes Culturales, Universidad Politécnica de Valencia. 
http://www.upv.es/entidades/DCRBC/index-es.html (consultado el 4 de octubre de 2010).

- DíAz BALERDI, Iñaki. "La formación de profesionales de museos. De la mística de la conservación al absolutismo de la gestión". En Revista de Museología, N²4, 2010. pp. 8-16.

- DiAZ-MARTINEZ, Soledad. "Ética, estética y economía, criterios de restauración en la verja del Museo Arqueológico Nacional de Madrid". En Actas del I Congreso del GEIIC. Conservación del Patrimonio: evolución y nuevas perspectivas. Valencia. 25, 26 y 27 de Noviembre de 2002.

- DiAz MARTOS, Arturo. Restauración y conservación del arte pictórico. Madrid, 1974.

- Difusión y comunicación en los Museos. Ministerio de Cultura, Gobierno de España. http://www.mcu.es/museos/CE/Funciones/Difusion/Introduccion.h tml (Consultado el 30 de junio de 2010).

- Documentación en los museos. Ministerio de Cultura. Gobierno de España.

http://www.mcu.es/museos/CE/Funciones/Documentacion/Documenat acioncolecciones.html (Consultado el 30 de junio de 2010).

- Domus. Ministerio de Cultura. Dirección General de Bienes Culturales y Bellas Artes. Subdirección General de Museos Estatales.

http://www.mcu.es/museos/CE/Funciones/Documentacion/Documenat acioncolecciones.html (Consultado el 30 de junio de 2010).

- Domus. Estado actual de la implantación. Ministerio de Cultura. Dirección General de Bienes Culturales y Bellas Artes. Subdirección General de Museos Estatales. http://www.mcu.es/museos/CE/Funciones/Documentacion/Documenat acioncolecciones.html (Consultado el 30 de junio de 2010).

- EGIDO, Marián del... et alt. "Estudio analítico mediante espectroscopía de fluorescencia de Rayos-x de fotografías históricas". En Actas del II Congreso del GEIIC. 
Investigación en Conservación y Restauración. Universidad de Barcelona, 9-11 de Noviembre de 2005.

- ESCOCHOTADO IBOR, Teresa. "La formación de los restauradores-conservadores de arte contemporáneo, un reto: de la formación tradicional a la actual". En Revista de Museología, $\mathrm{N}^{\circ}$ 5, julio de 1995.

- ESPI LLUNCH, Joaquín. "Problemas y soluciones a los licenciados en paro: por un museo del Patrimonio Recuperado". En IX Congreso de Conservación y Restauración de Bienes Culturales. Sevilla, 17-20 de septiembre de 1992. pp.66-69.

- estrada CASTRo, María Teresa. "El público del museo: ¿una incógnita?". En Revista de Museología, Nº 35, 2006, pp. 5255 .

- estradA CAStRo, María Teresa... et alt. "Estudio de público en el Museo Palacio de Junco: un entorno poco conocido". En Revista de Museología, No39, 2007, pp. 16-29.

- EZRATI, Jean-Jacques. "Iluminación museográfica". En Curso de Iluminación Museográfica. ICOM, Argentina, 3-5 de Mayo de 2006.

- Federación Española Amigos de los Museos. Ministerio de Cultura, Gobierno de España. http://www.feam.es/Inicio3.asp (consultado el 5 de octubre de 2010).

- FERNÁNDEZ ARENAS, José. Introducción a la conservación del patrimonio y técnicas artísticas. Barcelona. Ariel, 1996. - FERNÁNDEZ IBÁÑEZ, Carmelo. "Los laboratorios de conservación en los museos arqueológicos". En Archivos, Bibliotecas y Museos. Décimo Congreso de Estudios Vascos. Pamplona, 1987. pp. 469-472.

- "Montaje y funciones del laboratorio de conservación y restauración en un Museo de Arqueología". En Cuadernos de Prehistoria y Arqueología. $\mathrm{N}^{\circ} 23$, 1996. pp. 9-36. 
- FERRER, Nuria. "Comparación de diversos métodos de análisis basados en la espectroscopia infrarroja, y su aplicación a la caracterización de muestras procedentes del Patrimonio Cultural". En Actas del II Congreso del GEIIC. Investigación en Conservación y Restauración. Universidad de Barcelona, 9-11 de Noviembre de 2005.

- FERRERAS REMESAL, Alberto... et alt. Salud Laboral. Manual para la prevención de riesgos ergonómicos y psicosociales en Ios centros de atención a personas en situación de dependencia. Valencia. Instituto de Biomecánica de Valencia, 2006.

- Figuras NOGUÉS, Xavier, MIRAMBell ABAnCó, Miquel. "La necesidad de un nivel equivalente a la licenciatura universitaria en las enseñanzas de conservación y restauración de bienes culturales en España. Revisión y proyecto de Plan de Estudios de la Escuela Superior de Conservación y Restauración de Bienes Culturales de Cataluña". En Actas del I Congreso del GEIIC. Conservación del Patrimonio, evolución y nuevas perspectivas. Valencia, 25-27 de noviembre de 2002.

- FitzMAURice Mills, John. Los Conservadores de Obras de Arte. Madrid. Centro de Información para Médicos, 1977.

- FLORES CRESPO, Ma del Mar. "La museología crítica y los estudios de público en los museos de arte contemporáneo: caso del museo de Arte Contemporáneo de Castilla y León, MUSAC". En De Arte, No 5, 2006, pp. 231-243.

- GANDARILlAS, Marco A., QUiJANO, Fernando. Patología laboral. Claves para el diagnóstico y gestión administrativa. Santander. Consejería de Sanidad y Servicios Sociales, 2005.

- GARCíA BLANCO, Ángela. "¿Usuarios o visitantes de museos?". En Museo, $\mathrm{N}^{\circ}$ 6, 2002, pp. 1-18. 
- GARCíA CANO, José Miguel. "La documentación en el Museo Arqueológico de Murcia". En Anales de documentación. N 2, 1999, pp. 159-168.

- GARCÍA FERNÁNDEZ, Isabel. La Conservación Preventiva y la Exposición de Objetos y Obras de Arte. Murcia, 1999.

- "La conservación preventiva y las exposiciones temporales. Normas y condicionantes". En Curso sobre Exposiciones temporales y conservación del Patrimonio. Grupo Español del IIC. Facultad de Geografía e Historia de, Universidad Complutense de Madrid. Madrid, 5 al 8 de Abril, 2005.

- GARCíA LOZANO, Rocío... et alt. "La formación de auxiliares de restauración de documentos. La experiencia de los talleres del Centro de Restauración de Documentos del Archivo Histórico Municipal de Bilbao". En VIII Congrés de conservació de Bens Culturals, 20-23 de septiembre de 1990, Valencia. Pp. 40-49.

- GARCÍA-ORMAECHEA QUERO, Carmen. "La investigación externa en el Museo". En Museo, No 2, 1997, pp. 287-291.

- GARCíA SÁIZ, María Concepción. "La documentación en los museos: una para todos y todos para una". En Museo, $\mathrm{N}^{\circ}$ 2, 1997, pp. 104-111.

- GARCíA SERRANO, Federico. "Museología, soporte teórico a la investigación del museo". 28 de julio de 2008. http: / / correodelasculturas.wordpress.com/2008/07/28/museologi a-soporte-teorico-a-la-investigacion-del-museo/ (Consultado el 16 de julio de 2010).

- GARRIDO PÉREZ, María del Carmen. "El gabinete de documentación técnica del Prado". En Museo, N² 2, 1997. pp. 172-177.

- GIL NOVOA, D... et alt. "Estudio del equipo de difracción de Rayos X Tel-x-Ometer, Tel. 580". En Revista de la Sociedad Colombiana de física, Volumen 38, $\mathrm{N}^{\circ}$ 2, 2006. pp. 786-789. 
- GÓmez, Marisa, DE TAPOL, Benoit. "Medio siglo de Conservación Preventiva. Entrevista a Gaël de Guichen". En Ge-conservación, $\mathrm{N}^{\circ}$ 0, 2009. pp. 35-44.

- GÓMEZ GONZÁLEZ, Ma Luisa. Examen científico aplicado a la conservación de obras de arte. Madrid. Instituto de Conservación y Restauración de Bienes Culturales, 1994. - GÓmeZ-GIl AizpúruA, Carlos. "Instalación de un laboratorio de restauración de materiales de procedencia subacuática". En Monte Buciero, No 9, 2003. pp. 371-380.

- GÓMEZ VARGA, J. D. "Microscopía electrónica de barrido ambiental". En Revista de plásticos modernos: Ciencia y tecnología de polímeros, $\mathrm{N}^{\circ}$ 571, 2004 . pp. 51-71.

- GonzÁlez, María Irene, CAStRo, Mario. Estudios de Público en los Museos de la Dibam.

www.dibam.cl/descarga rec.asp?id recurso=62, (consultado el 17 de junio de 2010).

- GONzÁlez FeRnÁndez, Marcelino. "El Museo Naval de Madrid: su historia y actualidad". En Museos.es, $\mathrm{N}^{\circ}$ 2, 2006 . pp. 138-147.

- gonzÁlez MORO, Ana, AlBA CARCElÉn, Laura. "Uso de la ultravioleta para el estudio del estado de conservación de la pintura de caballete". En Actas del II Congreso del GEIIC. Investigación en Conservación y Restauración. Universidad de Barcelona, 9-11 de Noviembre de 2005.

- GONZÁlez TORNEL, Pablo. "El Taller de Restauración del Museo Nacional d'Art de Catalunya en la Posguerra". En Congreso Internacional Imagen Apariencia. Noviembre, del 19, 2008-Noviembre 21,2008, 2009.

- Grupo Español de Conservación. http://geiic.com/index.php?option=com content\&task=blogsection \&id=7\&It emid=49 (consultado el 8 de julio de 2010).

- GUIAMET, Patricia, Gómez DE SARAVIA, Sandra. "Técnicas utilizadas en el estudio de Biofilms que afectan a materiales 
pertenecientes al Patrimonio Cultural". En Jornadas de Avances de Técnicas Analíticas Aplicadas al Estudio de Materiales en Arte y Arqueología (TECNARTE), Universidad de Buenos Aires (Argentina), 11-13 de junio de 2008.

- HENARES CUÉlLAR, Ignacio. "¿Qué hacer con los monumentos?". En Arqueología del monumento: Terceros Encuentros de Arqueología y Patrimonio. Salobreña, del 13 al 16 de octubre de 1992/ coord. por Domingo Armada Morales, 1999. pp. 15-28.

- Historia del Arte, pensamiento y sociedad. Granada. Universidad, 2003.

- Reflexiones sobre la necesaria cooperación entre administraciones en la Gestión del Patrimonio. En PH: Boletín del Instituto Andaluz del Patrimonio Histórico, Año $\mathrm{n}^{\circ}$ 7, $\mathrm{N}^{\circ}$ 27, 1999. pp. 124-125.

- HENRI RIVÍERE, Georges. La Museología: Curso de Museología, textos y testimonios. Madrid. Akal, 1989.

- HERAS COBO, Carlos, GUARDINO SOLÁ, Xavier. "La ventilación general en el laboratorio". En SIAFA, Seguridad, Higiene y Medio Ambiente.

http://www.siafa.com.ar/notas/nota41/ventilacion.htm

(Consultado el 2 de Septiembre de 2010).

- HEREZA LEBRón, Pablo... et alt. "La calidad como herramienta de implantación de DOMUS en los museos de Andalucía". En MusA, $N^{\circ}$ 8, Julio 2007, pp. 145-147.

- HERNÁNDEZ SANZ, Jorge. "Condiciones ambientales en exposiciones". En Curso sobre Exposiciones temporales y conservación del Patrimonio. Grupo Español del IIC. Facultad de Geografía e Historia de, Universidad Complutense de Madrid. Madrid, 5 al 8 de abril, 2005.

- HERRAEZ, Juan A., RODRÍgueZ LORITE, Miguel A. Manual para el uso de aparatos y toma de datos de las condiciones ambientales en museos. Madrid. Ministerio de Cultura, 1999. 
- "La Conservación preventiva de las obras de Arte". En ARBOR, CLXIV, 645, Septiembre de 1999. pp. $141-156$.

- Holm, Stuart A. Facts \& Artefacts. How to document a museum collection. Cambridge. Museum Documentation Association, 1991.

- Introducción a la difusión y comunicación en los Museos. Ministerio de Cultura. Dirección General de Bienes Culturales y Bellas Artes. Subdirección General de Museos Estatales. http://www.mcu.es/museos/CE/Funciones/Difusion/Introduccion.h tml (Consultado el 30 de junio de 2010).

- Introducción a la documentación en los Museos. Ministerio de Cultura. Dirección General de Bienes Culturales y Bellas Artes. Subdirección General de Museos Estatales. http://www.mcu.es/museos/CE/Funciones/Documentacion/Introducc ion.html (Consultado el 30 de junio de 2010).

- Introducción a la investigación en los Museos. Ministerio de Cultura. Dirección General de Bienes Culturales y Bellas Artes. Subdirección General de Museos Estatales. http://www.mcu.es/museos/CE/Funciones/Investigacion/Introducc ion.html (Consultado el 30 de junio de 2010).

- INSÚA LACABE, Eugenia. "Las colecciones de las Bibliotecas de los Museos Estatales". En LIBER 20008, Mesa redonda sobre bibliotecas especializadas y la gestión de sus colecciones, Barcelona, 9 de octubre de 2008. pp. 1-9.

- International Committee for the Training of Personnel. http://ictop.alfahosting.org/(consultado el 6 de octubre de 2010).

- JONAthan RAPHAEL, Toby. Guía de Preservación de Colecciones. Una introducción al Cuidado de Colecciones para Museos Comunitarios. Madrid. Fundación Interamericana de Cultura y Desarrollo. 2009. 
- Jornada: Seguridad en los museos y edificios de valor patrimonial. Organizan: ICOM Argentina, CICOP Argentina, Banco Provincia de Buenos. 21 de octubre de 2009, Perú. En Noticias del ICOM Argentina, Número 3, año I, Diciembre de 2009. http://icom.newspoint.com.ar/online.php?S1=7\&idu=2347 (Consultado el 15 de agosto de 2010).

- KREBS KAULEN, Magdalena. "La formación de los conservadores-restauradores en Chile: contexto, balance y desafíos". En Ge-conservación, $\mathrm{N}^{\circ}$ 0, 2009. pp. 9-20.

- "La documentación en el museo". En Normalización documental de Museos. Ministerio de Cultura. Gobierno de España. pp. 7-16, 1998.

- "La falta de seguridad en los museos". Belt Ibérica S.A. El Portal de los Profesionales de la Seguridad y Emergencias. http://www.belt.es/noticiasmdb/HOME2 noticias.asp?id=402

Miércoles, 8 de febrero de 2006 (Consultado el 11 de agosto de 2010).

- "La UPV lidera un proyecto nacional para crear un archivo histórico de restauradores españoles", 18 de enero de 2010. En Qué.es, Periódico de Valencia.

http://www que.es/valencia/201001181028-upv-lidera-proyectonacional-crear.html (consultado el 4 de octubre de 2010).

- LAsheras CorruchagA, José Antonio... et alt. "La investigación en el Museo Nacional y Centro de Investigación de Altamira: investigar para conservar, para conocer, para difundir". En Museos.es, $\mathrm{N}^{\circ}$ 4, 2008. pp. 30-41. - Ley 16/1985 del 25 de junio de 1985. (B.O.E. n 155 de 29 de junio de 1985).

- LÓPEZ BORGES, Víctor Hugo. "Planificación, la clave del éxito en el departamento de conservación de escultura del V\&A". En Actas del III Congreso del GeIIC. La conservación infalible: de la teoría a la realidad. Oviedo, 21-23 Noviembre, 2007. pp. 341-351. 
- LÓPEZ de PRADo, María del Rosario. "Bibliotecas de museos en España: características específicas y análisis DAFO". En Revista general de Información y Documentación, Vol. 13, № 1,2003 . pp. 5-35.

- "DIDO: Proyecto para la digitalización de documentos en la Biblioteca del Museo Arqueológico Nacional". En $A N A B A D$, Tomo 43, $\mathrm{N}^{\circ}$ 3-4, 1999. pp. 499-507.

- López, Tomás. "Seguridad contra incendios en museos". En Belt Ibérica S.A.

http://www.belt.es/expertos/experto.asp?id=2039, 9 de julio de 2004. (Consultado el 15 de agosto de 2010).

- LORD, Barry y LORD, Gail Dexter. Manual de gestión de museos. Barcelona, 1998.

- LUAÑA, Víctor... et alt. Espectroscopía molecular. Universidad de Oviedo, 2002.

- LUQUe CEBALlos, Isabel... et alt. "El mercado laboral y la formación de los profesionales de los museos en Andalucía". En Revista de Museología, $N^{\circ}$ 13, 1998. pp. 38-42.

- MACARRÓN MIGUEL, Ana María. La conservación y restauración en el siglo XX. Barcelona. Tecnos, 2004.

- Historia de la conservación y la restauración. Desde la antigüedad hasta el siglo XX. Barcelona. Tecnos, 2002 .

- Conservación del Patrimonio Cultural. Criterios y normativas. Madrid. Síntesis, 2008

- MAgÁN PERALES, José Ma Aristóteles. "La organización administrativa de la formación de conservadores y restauradores. La oportunidad de contar con una licenciatura propia tras el sistema europeo de Bolonia". En Patrimonio Cultural y Derecho, $\mathrm{N}^{\circ} 11$, 2007. pp. 49-76.

- MAIER, Marta. "Potencial de la Espectrometría de Masa como herramienta para la identificación de compuestos orgánicos en 
Bienes Culturales". En Jornadas de Avances de Técnicas Analiticas Aplicadas al Estudio de Materiales en Arte $y$ Arqueología (TECNARTE), Universidad de Buenos Aires (Argentina), 11-13 de junio de 2008 .

- MARCO SUCH, María. Estudio y análisis de los museos y colecciones museográficas de la provincia de Alicante. Universidad de Alicante, 1998.

- MARTIARENA, Xabier. "Conservación y Restauración". En Cuadernos de Sección. Artes Plásticas y Documentales. $\mathrm{N}^{\circ} 10$, 1992. pp. 177-224.

- MARTÍNEZ, B... et alt. "Espectrometría de fluorescencia de Rayos X". En Revista de la Sociedad Colombiana de física, Volumen 38, $\mathrm{N}^{\circ}$ 2, 2006. pp. 790-793.

- MAtTeini, Mauro. La química en la restauración: los materiales del arte pictórico. Madrid. Nerea, 2001.

- MIRALles ROCA, Judith... et alt. "Aplicaciones de las tecnologías fotónicas al análisis y limpieza de obras de arte". En Actas del II Congreso del GEIIC. Investigación en Conservación y Restauración. Universidad de Barcelona, 9-11 de Noviembre de 2005.

- MiRAMBELl ABANCó, Miquel. "El nuevo grado en conservación y Restauración de Bienes Culturales: un reto para la ESCRBCC". En XTEX, Xarxa Telemática Educativa de Catalunya. http://ww.xtec.es/centres/a8044961/El nuevo grado.pdf (consultado el 24 de septiembre de 2010).

- MONTAÑ̃́s, Carmen (coord.). El museo. Un espacio didáctico y social. Barcelona. Mira editores, 2001.

- MONTero, Antonio, DiÉGuez, Carmen. "Problemática y organización de los traslados de fondos paleontológicos". En ANABAD, Tomo 41, $\mathrm{N}^{\circ}$ 2, 1991, pp. 163-171.

- MONTES PRIETO, Rosario, MARTínez, Juan Manuel. "Bases teóricas y prácticas para un Plan Integrado de Emergencia para colección". En Actas del III Congreso del GEIIC. La 
conservación infalible: de la teoría a la realidad. Grupo Español del IIC. Oviedo, 21, 22 y 23 de Noviembre, 2007.

- MORALES, Alfredo J. Patrimonio histórico-artístico. Madrid. Historia 16, 1996.

- MORENO CIFUENTES, Ma Antonia. "Documentar la restauración". En Museo: Revista de la Asociación Profesional de Museólogos de España. No 2, 1997. pp. 178-182.

- MORENO CIfUentes, Ma Antonia, SEDANO ESPIN, Pilar. "La investigación en los laboratorios de restauración de museos históricos". En ARBOR, Tomo CLXXXII, N 717, enero-febrero, 2006. pp. 87-97.

- MORENO RODRÍgUEZ, Rosa. "Laboratorio de Investigación en el Museo del Louvre". En Cuadernos de Restauración, $\mathrm{N}^{\circ}$ 2, 2000. pp. 51-57.

- MORÓN DE CASTRO, María Fernanda. "La situación actual del restaurador en los museos andaluces". En IX Congreso de Conservación y Restauración de Bienes Culturales. Sevilla, 17-20 de septiembre de 1992. pp. 96-101.

- MUÑOz CAMPOS-GARCíA, Paloma. "La Conservación preventiva en los museos de artes decorativas. El reto del almacenamiento". En Revista de Museología, $\mathrm{N}^{\circ}$ 36, 2006 . pp. 124-134.

- "Conservación preventiva de colecciones textiles: primer paso". En Curso El textil y la indumentaria, Grupo Español del ICC en colaboración con el Instituto del Patrimonio Histórico Español (IPHE) y la Universidad Complutense de Madrid (UCM). Madrid, 31 de Marzo al 3 de abril, 2003.

- Museo Arqueológico Regional. Alcalá de Henares (Madrid). http://www.madrid.org/cs/Satellite?cid=1161230071838\&language =es\&pagename=Museos\%2FPage 2 FMUSE contenidoFinal (consultado el 9 de septiembre de 2010). 
- "Museo de Arte Oriental. Videovigilancia IP para 500 años de historia". MOBOTIX. Security-Vision-System.

http://WwW.mobotix.com/esl ES/Aplicaciones/Sistemas-de-

Seguridad/Vigilancia-de-Museo (consultado el 11 de agosto de 2010).

Nacional

de

Ciencias

Naturales.

http://www.mncn.csic.es (consultado el 7 de julio de 2010).

- Museo Naval de Madrid. Ministerio de Defensa.

http://www.armada.mde.es/ArmadaPortal/page/Portal/armadaEspan nola/ciencia museo/00 inicio (consultado el 8 de septiembre de 2010).

- NAVASCUÉS, Joaquín María. Instrucciones para la redacción del inventario general, catálogos y registros en los museos servidos por el Cuerpo Facultativo de Archiveros, Bibliotecarios y Arqueólogos. En B. O., $N^{\circ}$ 157. Ministerio de Educación Nacional, 1942.

- NICOLAus, Knut. Manual de restauración de cuadros. Cologne. Könemann, 1999.

- NogAles BASARRAte, Trinidad. "La investigación en los Museos. Una actividad irrenunciable". En Desde el Museo, $\mathrm{N}^{\circ}$ 0 . pp. 42-61.

- Normalización Documental de Museos: elementos para una aplicación informática de gestión museográfica. Ministerio de Cultura. Gobierno de España, 1996.

- OLMEDO PONCE, Marisa. "El Patrimonio Histórico-artístico de Antequera y el Taller Municipal de Restauración". En Boletín de la Sociedad de Amigos de la Cultura de VélezMálaga. $\mathrm{N}^{\circ}$ 4, 2005 . pp. 43-46.

- Olmos ROMERO, Ricardo. "La investigación (de la cultura material) en los museos: notas para un debate". En ANABAD, Tomo 38, $\mathrm{N}^{\circ}$ 3, 1988. pp. 91-106.

- "Investigadores y Museos: una lectura entre otras muchas". En Museo, $\mathrm{N}^{\circ}$ 6, 2002, pp. 1-11. 
- ORTEGA ORTEGA, Antonio. "Embalajes y materiales para el transporte de obras de arte". En Boletín del Instituto Andaluz del Patrimonio Histórico, $\mathrm{N}^{\circ}$ 16, Sevilla, 1996. pp. $60-62$.

- osvaldo Codignotto, Jorge. "Metodología y controles en la toma de muestras para determinación de edades por C14". En Jornadas de Avances de Técnicas Analíticas Aplicadas al Estudio de Materiales en Arte y Arqueología (TECNARTE), Universidad de Buenos Aires (Argentina), 11-13 de junio de 2008. pp. 11-13.

- palomares SAMper, José Ángel. "Almacenes en los museos". En Revista de Museología, Año IV, $N^{\circ}$ 13, Febrero de 1998. pp. 131-137.

- "Patrimonio (concepto desde España)". En Revista Digital Nueva Museología.

http://www.nuevamuseologia.com.ar/patrimoniol.htm (consultado el 7 de julio de 2010).

- Patronato de la Alhambra y Generalife. Consejería de Cultura. http://www.alhambra-patronato.es/ (Consultado el 9 de septiembre de 2010).

- PEINAdO FERNÁNDEZ, Javier, GARCíA FLAQUER, Julián. "La Escuela de Conservación y Restauración de Bienes Culturales de Madrid". En VIII Congrés de conservació de Bens Culturals, 20-23 de septiembre de 1990, Valencia. pp. 113-114.

- PEÑA SAINT MARTIN, Florencia, SÁNCHEZ DÍAZ, Sergio G. "El Mobbing $y$ su impacto en la salud". En http://www.acosomoral.org/pdf/comas2.PDF 2006. (consultado el 15 de agosto de 2010).

- PEQUEÑO LÓPEZ, Xosé A. "De ordine rerum". Como disfrutar de todas las posibilidades de la biblioteca del Museo de Melilla". En Akros, $\mathrm{N}^{\circ}$ 5, 2006. pp. 13-16.

- PÉREZ DE ANDRÉS, Carmen. "Conservación y Restauración de las otras colecciones". En Actas de los XII Cursos 
Monográficos sobre el Patrimonio Histórico. Reinosa, JulioAgosto de 2001. pp. 53-66.

- PÉReZ SANTos, Eloisa. Estudio de visitantes en Museos. Metodología y aplicaciones. Gijón. Trea, 2000.

- "Metodología básica de la investigación de público en museos: áreas de actuación, variables implicadas, tipos de investigaciones y técnicas utilizadas". En Mus-A, No 10, 2008, pp. 48-57.

- PESOA, Lucila. "Se inauguró el Taller de Conservación y Restauración del Museo Histórico Nacional". En Trabajadores de Museos, 4 de agosto de 2010.

http://trabajadoresdemuseos.blogspot.com/2010/08/se-inauguroel-taller-de-conservacion-y.html (consultado el 8 de septiembre de 2010).

- Política de prevención de riesgos laborales de Talleres de Arte Granada. Taller de Arte Granada S.A., 2008.

- PREgo DE LIS, María. "El papel de la biblioteca en el museo". En Museo, $\mathrm{N}^{\circ}$ 2, 1997. pp. 232-233.

- PRIETO, A. C... et alt. "Caracterización de pigmentos mediante espectroscopía Raman". En Actas del II Congreso del GEIIC. Investigación en Conservación y Restauración. Universidad de Barcelona, 9-11 de Noviembre de 2005.

- Programa de documentación de colecciones. Ministerio de Cultura, Dirección General de Bienes Culturales y Bellas Artes. Subdirección General de Museos Estatales. http://www.mcu.es/museos/CE/Funciones/Documentacion/Documenat acioncolecciones.html (Consultado el 30 de junio de 2010).

- Programa de Seguridad. Ministerio de Cultura. http://www.mcu.es/museos/docs/MC/PM/programas5.pdf

(consultado el 16 de agosto de 2010).

- Proyecto de investigación: Sistemas alternativos para extinción y previsión de incendios (polvo químico). Departamento de Restauración del Museo Thyssen-Bornemisza. 
- QuintanA, Alicia. "Museos: tipos, funciones y aprovechamiento didáctico". Jornadas celebradas en el Museo Nacional de Mérida. Www.museosabate.com/funciones.htm, 27 febrero 2007, (consultado el 17 de junio del 2010).

- R. CELMA, Antonio, L. ROdRÍguez, Fernando. "La iluminación en museos y exposiciones. Parámetros de diseño". En Electra, $\mathrm{N}^{\circ}$ 87, febrero de 1998. pp. 21-34.

- RAVÉ PRIETO, Juan Luis. "Educación en los Museos". En MusA, $\mathrm{N}^{\circ}$ 6, Abril 2006. pp. 26-31.

- Real Decreto 620/1987, de 10 de abril, por el que se aprueba el Reglamento de Museos de titularidad estatal y del Sistema Español de Museos.

- REGo, Paco. "Los peligros de la bombilla de ahorro". En EI mundo, $\mathrm{N}^{\circ}$ 638, domingo 13 de enero de 2008. http://www.elmundo.es/suplementos/cronica/2008/638/1200178806 .html (consultado el 24 de septiembre de 2010).

- RESÉNDIZ GONZÁLEZ, M. C., CASTRELLÓN-URIBE, Jesús. "Microscopio de Fuerza Atómica". En ENIVIE, Encuentro de Investigación de Ingeniería Eléctrica, Zacatecas (Méjico), 17-18 de Marzo de 2005. pp. 8-13.

- "Restauración en los Museos". Ministerio de Cultura. http://www.mcu.es/museos/CE/Funciones/Conservacion/Restauraci on.html (consultado el 28 de julio de 2010).

- REY SASTRE, Isabel, BERREAL ÉCIJA, Ma del Carmen. "Acercamiento a la labor realizada en el taller de restauración del Museo Provincial de Lugo". En Boletín do Museo Provincial de Lugo, No 9, 1999-2000. pp. 257-277.

- RICO, Juan Carlos. Montajes de exposiciones: museos, arquitectura, arte. Madrid. Síntesis, 1996.

- Manual práctico de Museología, museografía y técnicas expositivas. Madrid. Síntesis, 2006.

- RICO CANO, Lidia. "La difusión del Patrimonio a Través de las nuevas Tecnologías. Nuevos entornos para la educación 
patrimonial histórico-artística". En Formación de la ciudadanía: las TICs y los nuevos problemas, 2004.

- ROCHA NICOLÁS, Antonio. "Funciones y problemas de los correos que acompañan las Obras de Arte en su itinerancia". En ARBOR, Tomo CLXIV, $\mathrm{N}^{\circ}$ 645, Septiembre de 1999. pp. 109118 .

- RODRÍguez BRAVO, Blanca, SANTOS DE PAZ, Lourdes. "Del documento digital a la biblioteca virtual". En Scire, vol. 8, $\mathrm{N}^{\circ}$ 2, 2002. pp. 43-52.

- RODRÍgUez FRADE, Juan Pablo. "Criterios museográficos para la exposición de materiales escultóricos". En Museos.es, $\mathrm{N}^{\circ}$ 2, 2006, pp. 116-125.

- RODRÍguez LÓPEZ, M. V... et alt. "La colección de publicaciones periódicas especializadas de la Biblioteca del Museo Arqueológico Nacional: un estudio analítico". En Boletín del Museo Arqueológico Nacional, Tomo 15, $\mathrm{N}^{\circ}$ 1-2, 1997. pp. 259-272.

- RODRÍgUez MATÉS, Rosario. "Valoración de la protección jurídico-internacional del Patrimonio Cultural en periodo de conflicto armado ante el $50^{\circ}$ aniversario de la Convención de la Haya (1954-2004)". En Boletín de la Facultad de Derecho de Ia UNED, $\mathrm{N}^{\circ} 25,2004$. pp. 223-256.

- ROIG PICAZO, Pilar. "El futuro de la especialidad en Conservación y Restauración en la Facultad de Bellas Artes de la Universidad Politécnica de Valencia ante la reforma de los planes de estudio". En VII Congreso de Conservación de Bienes Culturales, 23-25 de septiembre 1990. pp. 67-69.

- Romero de tejAdA PicAtoste, Pilar. "La conducta ética entre los profesionales de museos, según algunos códigos internacionales europeos". En Museo, $\mathrm{N}^{\circ}$ 3, 1998. pp. 61-69.

- ROTAECHE Y GONZÁLEZ DE UBIETA, Mikel. Transporte, depósito y manipulación de obras de arte. Madrid. Síntesis, 2007. 
- RUIZ DE LACANAL RUIZ-MATEOS, María Dolores. Conservadores y restauradores: en la historia de la conservación y restauración de bienes culturales: estudio del perfil y la formación. Morón de la Frontera, 1994.

- El conservador-restaurador de bienes culturales: historia de la profesión. Madrid, 1999.

- "El conservador de museos en la primera mitad del siglo XX: conservadores de monumentos, jefes y directores, anticuarios $y$ arqueólogos". En ANABAD, Tomo 45, $\mathrm{N}^{\circ}$ 2, 1995. pp. 117-131.

- "Conservadores-Restauradores europeos: una definición y un código deontológico de la profesión". En Cuadernos de Restauración, $\mathrm{N}^{\circ} 0$, 1997. pp. 13-20.

- "El Conservador-restaurador: el eje de la historia de una profesión". En $X$ Congreso de Conservación de Bienes Culturales, 29-30 de septiembre, 1-2 de octubre de 1994, Cuenca. pp. 113-119.

- "Francisco Pacheco y la Restauración". En Laboratorio de Arte, $\mathrm{N}^{\circ}$ 7, 1994. pp. 319-325.

- RUIZ Gómez, Leticia. "Restauración en el Museo del Prado". Museo Nacional del Prado www.museodelprado.es (consultado el 28 de junio de 2010).

- SÁEz VACAS, Fernando. Más allá de Internet: la Red Universal Digital. Madrid. Centro de Estudios Ramón Areces, 2004 .

- SAN ANDRÉS MOYA, Margarita, DE LA VIÑA FERRER, Sonsoles. Fundamentos de química y física para la conservación y restauración. Madrid, 2004.

- SÁnchez-lassa de los SAntos, Ana. "El Departamento de Conservación y Restauración del Museo de Bellas Artes de 
Bilbao". En Actas de los XVI Cursos Monográficos de Patrimonio Histórico. Reinosa, del 18 al 22 de Julio, 2005.

- SANCHO CAMPO, Ángel. "La Comisión Provincial de Monumentos (1918-1961)". En Publicaciones de la Institución Tello Téllez de Meneses, $\mathrm{N}^{\circ}$ 69, 1998. pp. 7-54.

- SAndino Gómez, Rosa. "El arte de la seguridad. (I)". En Belt

Ibérica

S.A.

http://www.belt.es/expertos/experto.asp?id=2563, 16 de mayo de 2005. (Consultado el 15 de agosto de 2010).

- "El arte de la seguridad: el elemento humano. (II)". En Belt Ibérica S.A. http://www.belt.es/expertos/experto.asp?id=2654,

21 de julio de 20005. (Consultado el 15 de agosto de 2010).

- SAnguinetti, María del Rosario, GARRÉ, Fabián. "Estudio de Público: herramienta fundamental para el desarrollo de un proyecto de marketing de museos". En Seminario Virtual de información para archivos, bibliotecas y museos. Biblios, $\mathrm{N}^{\circ}$ 10. Lima, 20 de noviembre, 2001.

- SANTISTEBAN, Javier. "Análisis no-destructivos en arqueometría con Haces de Neutrones". En Jornadas de Avances de Técnicas Analíticas Aplicadas al Estudio de Materiales en Arte y Arqueología (TECNARTE), Universidad de Buenos Aires (Argentina), 11-13 de junio de 2008. pp. 23-25.

- SANZ LÓPEZ DE HEREDIA, Ainhoa. "Plan de Emergencias para obras de arte". En FMGB Guggenheim Bilbao Museoa. Bilbao, 2007 .

- SCHUBERT, Karsten. El Museo. Historia de una idea. Desde la Revolución Francesa a hoy. Granada. Turpiana, 2008.

- SEDANO ESPín, Pilar. "La Conservación de las Obras de Arte en los Museos. Funciones del Departamento de Restauración". En ARBOR, Tomo CLXIV, $\mathrm{N}^{\circ}$ 645, Septiembre de 1999. pp. 1-25. 
- "El área de restauración. Museo Nacional del Prado. Madrid". En Restauración \& Rehabilitación, $\mathrm{N}^{\circ} 109,2008$. pp. 50-75.

- "Montaje y gestión de Departamentos de conservación y restauración". En Actas de los XVI Cursos monográficos sobre Patrimonio Histórico. Reinosa, del 18 al 22 de Julio, 2005.

- SEDANO ESPIN, Ubaldo. "Conservación preventiva en el montaje de exposiciones". En Actas de los XVI Cursos Monográficos sobre el Patrimonio Histórico. Reinosa, Julio de 2005. pp. 201-212.

- "Seguridad contra los incendios en museos". En Belt Ibérica S.A. Expertos profesionales. Seguridad Corporativa y Protección del

Patrimonio. http://www.belt.es/expertos/experto.asp?id=1676 Octubre, 2003. (Consultado el 11 de agosto de 2010).

- "Seguridad en el Museo". En Revista Digital Nueva Museología. Febrero de 1994.

http://www.nuevamuseologia.com.ar/seguridad en el museo.htm

(consultado el 16 de agosto de 2010).

- Servicio de Salud Laboral y Prevención. Universidad de Alcalá, Madrid.

https://portal.uah.es/portal/page/portal/GP PREVENCION/PG HIG IENE/PG CONDICIONES HIGIENICAS (Consultado el 2 de Septiembre de 2010).

- SORIA ORTEGA, Andrés. "Sobre biografismo de la época clásica: Francisco Pacheco y Paulo Jovio". En 1616: Anuario de la Sociedad Española de Literatura General y Comparada, $N^{\circ}$ 4, 1981, pp. 123-143.

- Stem. Servicios Técnicos y Equipamientos para Museos. http://ww.stem-museos.com (consultado el 11 de agosto de 2010). 
- Tesauros de Patrimonio Cultural. Ministerio de Cultura. Gobierno de España.

http://www.mcu.es/museos/docs/Tesauros Patrimonio Cultural.pd f (Consultado el 30 de junio de 2010).

- thompson, G. El museo y su entorno. Madrid. Akal, 1998.

- Tillotson, Robert G. La seguridad en los museos. Madrid. Ministerio de Cultura, 1980.

- Título: Grado en Conservación y Restauración de Bienes Culturales. ANECA, Universidad de Granada, 2009.

- TORRES VARGAS, Georgina Araceli. El concepto de biblioteca virtual y su relación con el acceso universal a los documentos. Madrid. Universidad Complutense de Madrid, 2000 .

- URREA FERNÁNDEZ, Jesús. "Las funciones del museo: una línea de exposiciones". En Exposiciones, Sección VI, pp. 219223 .

- URUEÑA ÁlVAREZ, Rafaela. "La protección del patrimonio cultural en tiempo de guerra y paz". En Cuadernos de estudios empresariales, $\mathrm{N}^{\circ}$ 14, 2004. pp. 245-260.

- VALDÉS SAGÜÉS, Ma del Carmen. La difusión cultural en el museo: servicios destinados al gran público. Gijón. Trea, 1999.

- VAleRA RESTREPo, José Joaquín. "La Biblioteca del Museo Martorell y los orígenes del coleccionismo zoológico en Barcelona". En Actes d'Historia de la Ciència i de la Tècnica, Vol. 1, $\mathrm{N}^{\circ} 1,2008$. pp. 111-118.

- VÁzQUEz, Cristina. "Una mirada al arte y a la arqueología con ojos de Rayos X". En Jornadas de Avances de Técnicas Analiticas Aplicadas al Estudio de Materiales en Arte $y$ Arqueología (TECNARTE), Universidad de Buenos Aires (Argentina), 11-13 de junio de 2008. pp. 17-22.

- VELA, Concha. "El Departamento de Registro del Museo de Arte Moderno de Nueva York: la importancia del Departamento 
de Registro como base de la organización de los museos". En ANABAD, Tomo XXXIV, $\mathrm{N}^{\circ}$ 2-4, 1984. pp. 239-262.

- VILLAFRANCA JimÉnEZ, María del Mar. "Los museos andaluces: pasado, presente y perspectivas de futuro". En Revista de Museología, $\mathrm{N}^{\circ}$ 13, febrero de 1998. pp. 27-37.

- VIÑAS LUCAS, Ruth. "Los estudios superiores de Conservación y Restauración de Bienes Culturales y su adaptación al Espacio Europeo de Educación Superior". En Pátina, $\mathrm{N}^{\circ}$ 15, diciembre de 2008. pp. 283-298.

- XARRIÉ I ROVIRA, Josep María. "El Centro de Conservación y Restauración de Bienes Culturales". En Catalònia Cultura, $\mathrm{N}^{\circ} 11,1998$. pp. 30-31.

- YÁÑEZ ANLLó, Lucila. "Sala de exposiciones temporales. Museo Provincial". En Boletín do Museo Provincial de Lugo, $\mathrm{N}^{\circ}$ 5, 1992, pp. 179-194. 